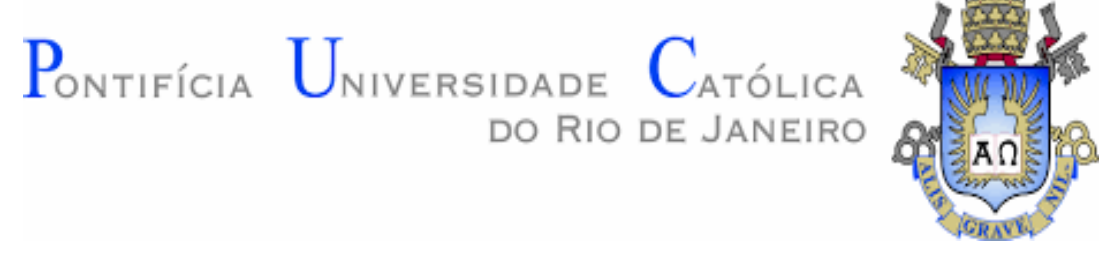

Remo Mannarino Filho

\title{
A carta VII de Platão e as origens filosóficas do discurso autobiográfico
}

\section{Tese de Doutorado}

Tese apresentada como requisito parcial para obtenção do grau de Doutor pelo Programa de Pós-Graduação em Filosofia da PUC-Rio.

Orientadora: Prof ${ }^{a}$. Maura Iglésias 


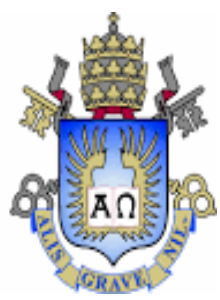

Remo Mannarino Filho

\section{"A carta VII de Platão e as origens filosóficas do discurso autobiográfico"}

Tese apresentada com requisito parcial para obtenção do grau de Doutor pelo Programa de Pós-Graduação em Filosofia do Departamento de Filosofia do Centro de Teologia e Ciências Humanas da PUC-Rio. Aprovada pela Comissão Examinadora abaixo assinada.

Profª. Maura Iglésias

Orientadora

Departamento de Filosofia - PUC-Rio

Prof ${ }^{a}$. Irley Fernandes Franco Departamento de Filosofia - PUC-Rio

Prof ${ }^{a}$. Luisa Severo Buarque de Holanda

Departamento de Filosofia - PUC-Rio

Prof. Marcus Reis Pinheiro Universidade Federal Fluminense - UFF

Prof ${ }^{a}$. Ana Flaksman

Universidade Federal do Estado do Rio de Janeiro - UNIRIO

Profa. Monah Winograd

Coordenadora Setorial de Pós-Graduação e Pesquisa do Centro de Teologia e Ciências Humanas - PUC-Rio

Rio de Janeiro, 25 de abril de 2017. 
Todos os direitos reservados. É proibida a reprodução total ou parcial do trabalho sem a autorização da universidade, do autor e do orientador.

\section{Remo Mannarino Filho}

Professor do Departamento de Filosofia da PUCRio e do curso de Especialização em Filosofia Antiga da CCE/PUC-Rio. Mestre em Filosofia pela mesma instituição (2008), com estágio de pesquisa como "visiting scholar" na Brown University (EUA). Pós-graduado em Filosofia Contemporânea (2006) e graduado em Comunicação Social (2001) também pela PUC-Rio.

Ficha Catalográfica

Mannarino Filho, Remo

A carta VII de Platão e as origens filosóficas do discurso autobiográfico / Remo Mannarino Filho; orientadora: Maura Iglésias. - 2017.

184 f. ; $30 \mathrm{~cm}$

Tese (doutorado)-Pontifícia Universidade Católica do Rio de Janeiro, Departamento de Filosofia, 2017.

Inclui bibliografia

1. Filosofia - Teses. 2. Platão. 3. Carta VII. 4. Autobiografia. I. Iglésias, Maura. II. Pontifícia Universidade Católica do Rio de Janeiro. Departamento de Filosofia. III. Título. 


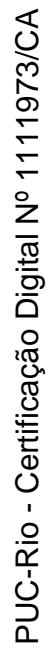

Para Maura Iglésias. 


\section{Agradecimentos}

Àquele em Quem nos movemos, vivemos e somos. À Santíssima Virgem, ao cego Bartimeu, a Antão do Egito, a Agostinho de Hipona, a Gertrudes de Helfta, a Hildegarda de Bingen, a Teresa de Ávila, a Bento de Núrsia, pelas constantes intercessões.

A Maura Iglésias, pela paciência infinita.

Aos membros da banca, pela leitura generosa e pelas pertinentes observações que fizeram sobre este trabalho.

A meus pais, a minhas irmãs, a meus sobrinhos, pelo apoio afetivo.

A Lívia Boeschenstein, por tudo - especialmente por vencer as hidras da ABNT e do Word Office.

A Maria Inês e a Priscilla Coelho, amigas e colegas sem cujo incentivo e afeto esta tese não seria concluída. Aos amigos Luiz Augusto Astorga e Victor Pinheiro, pela parceria espiritual e intelectual. Aos amigos Daniel, Marcelo, Miguel, Pedro, Rogério, Tiago, Thiago, Victor, Vitor, Camila, Paula, Fábio e Leandro, pelo apoio e pela torcida.

Ao inventor do método Pomodoro, quem quer que seja.

Ao povo árabe, pelo café.

À PUC-Rio, pela bolsa de isenção concedida e estendida. Ao Departamento de Filosofia, por toda a ajuda e compreensão nos momentos críticos. Aos meus colegas professores, por todo o apoio.

A Gustavo Machado Carregal e Maurício Rodrigues Freire, policiais que recuperaram, em ação pacífica e exemplar, um computador furtado em que se encontrava uma parte significativa desta pesquisa. 


\section{Resumo}

Mannarino Filho, Remo; Iglésias, Maura. A Carta VII de Platão e as origens filosóficas do discurso autobiográfico. Rio de Janeiro, 2017. 183p. Tese de Doutorado - Departamento de Filosofia, Pontifícia Universidade Católica do Rio de Janeiro.

A presente tese tem como tema uma análise da dimensão filosófica do discurso autobiográfico apresentado por Platão na carta que passou a ser conhecida, desde a compilação de Trasímaco, como a Carta VII. A tradição de comentários e interpretações estabeleceu o hábito de considerar a carta como sendo um documento de grande importância historiográfica, uma fonte de informações sobre a política da Siracusa no séc. IV a.C. e sobre a própria vida de Platão, mas não como uma obra de caráter filosófico - exceto pelo "excurso" teórico apresentado no passo 341a345c. A pesquisa aqui apresentada defende uma tese diferente: o texto de apresentação, escrutínio e justificativa da própria trajetória biográfica tem, ele próprio, um caráter filosófico, na medida em que faz culminar a apropriação socrático-platônica do preceito délfico "Conhece-te a ti mesmo". Para sustentar a tese, o texto apresenta uma análise da história desse preceito na cultura grega, e o sentido dessa apropriação filosófica no contexto maior da obra de Platão. Além disso, a tese também se ocupa da controversa questão da autoria do texto, contestada por parte dos estudiosos. Ao tratar da questão da autenticidade ou espuriedade do texto, a pesquisa faz um inventário crítico que divide os argumentos favoráveis e contrários em vários tipos - argumentos estilísticos, estilométricos, historiográficos e filosóficos -, e termina por posicionar-se sobre o tema.

\section{Palavras-chave}

Platão; Carta VII; autobiografia. 


\section{Abstract}

Mannarino Filho, Remo; Iglésias, Maura (Advisor). Plato's Seventh Letter and the philosophical origins of autobiography. Rio de Janeiro, 2017. 183p. Tese de Doutorado - Departamento de Filosofia, Pontifícia Universidade Católica do Rio de Janeiro.

This thesis explores the philosophical dimension of the autobiographical discourse presented by Plato in the text known, since the compilation made by Trasimacus, as the Seventh Letter. The tradition of commentary and interpretation has established the use of reading the letter as a document of great historigraphical importance, as a source of information about the political affairs in Siracuse during the IV century b. C., and about Plato himself - but not as a work of philosophical nature (except for the "digression" in 341a-345c). The present research proposes a different idea: a piece of writing in which Plato presentes, examins and justifies his own biographical trajectory has in itself a philosophical nature, insofar as it fulfills the socratic-platonic appropriation of the Delfic precept "Know thyself". To defend the hypothesis, the research analyses the history of the Delfic principle in Ancient Greece, and the deep meaning of the mentioned appropriation in the wider context of Plato's works. Besides, the present thesis also delas with the controvert subjetc of the letter's authenticity, challenged by some scholars. In dealing with this matter, the research will present a critic inventory that sorts in kinds all the arguments, both contrary and favorable to the authenticity - the ones based on style, stylometry, History and philosophy - and, at last, it takes a stand on that issue.

\section{Keywords}

Plato; Seventh Letter; autobiography. 


\section{Sumário}

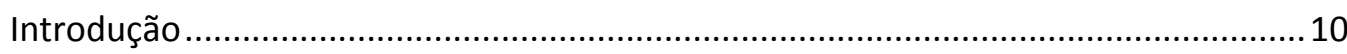

1. Uma introdução panorâmica à Carta VII .............................................................. 13

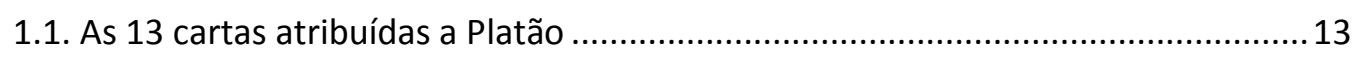

1.2. Contextualização e pano-de-fundo histórico ......................................................... 14



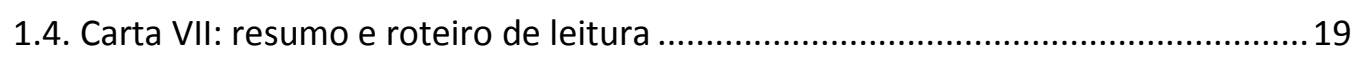

2. A controvérsia em torno da autenticidade da Carta VII.............................................22

2.1. Apresentação do problema............................................................................... 22

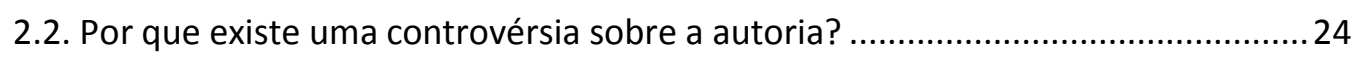

2.3. Uma tentativa de organização tipológica dos argumentos em torno da questão. 28



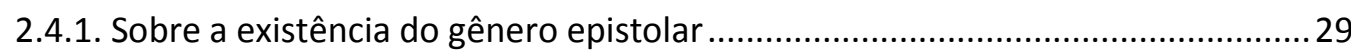

2.4.2. O testemunho de Diógenes Laércio, e os testemunhos indiretos de Trasilo e

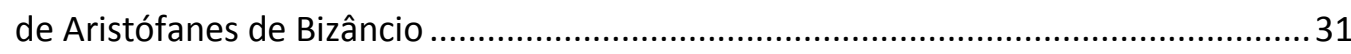

2.4.3. Os testemunhos de Cícero, de Pomponius Atticus, de Plutarco e de Luciano ... 33

2.4.4. Uma questão historiográfica controversa: o estatuto das cartas da

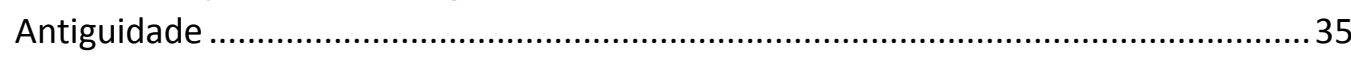

2.4.5. A questão historiográfica interna: são fidedignos os fatos descritos na

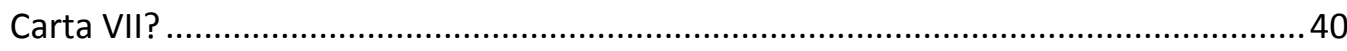

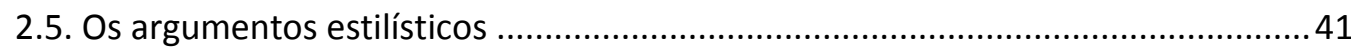

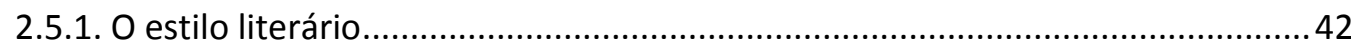

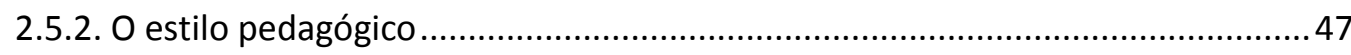

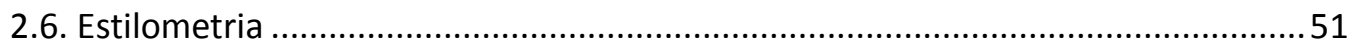

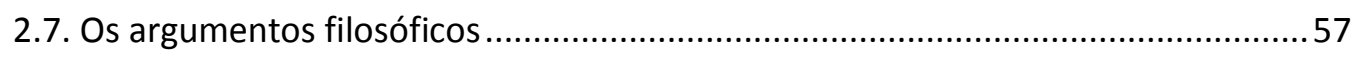

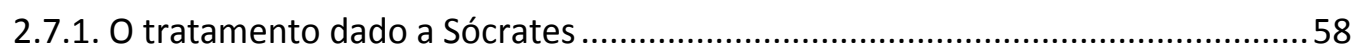

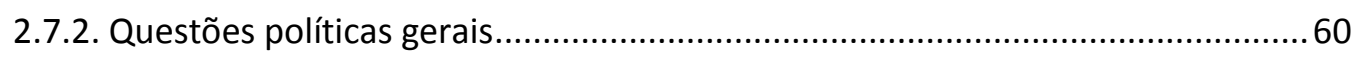

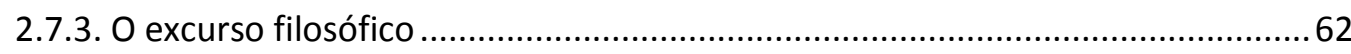

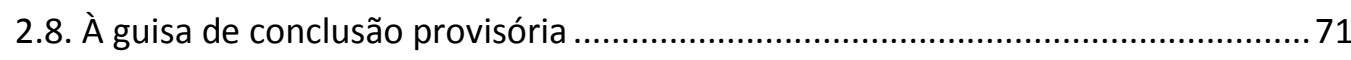

3. "Conhece-te a ti mesmo" e o surgimento da noção abstrata de tò aủtó na

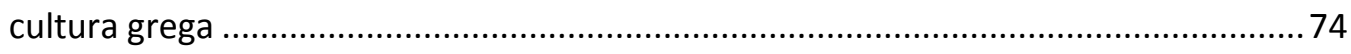

3.1. O surgimento do gênero autobiográfico em contexto filosófico........................... 74

3.2. A longa gestação de uma noção filosófica, ou: conhecer o que, exatamente?..... 79

3.2.1. Snell, Schmitz, Dodds: o surgimento da noção abstrata de "sujeito" e a



3.2.2. A. A. Long: Encontrar a si próprio, o que fazer consigo ..................................... 95 
3.2.3. Cornford: a filosofia grega chega à vida adulta. 103

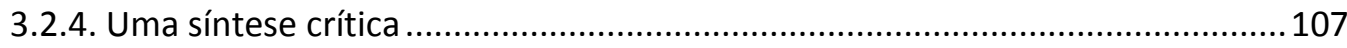

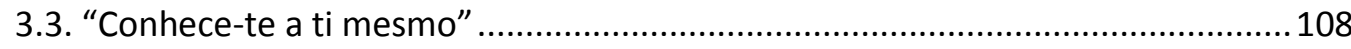

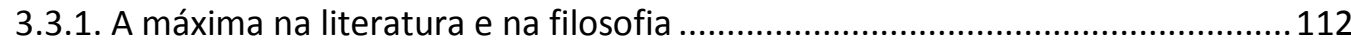

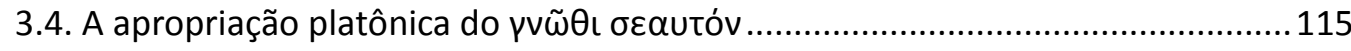

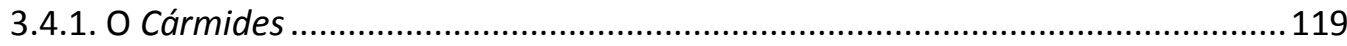

3.4.2. O Primeiro Alcibíades: o "si mesmo" não é um dado, mas uma questão..........121

3.4.3. Protágoras, Fedro, Filebo, Leis. Um exame da apropriação filosófica ............... 125

3.4.4. A "vida examinada": o preceito délfico também no tempo, não apenas no

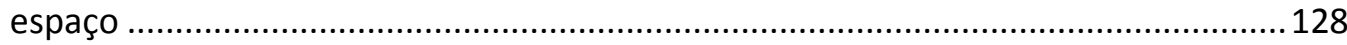

4. A Carta VII, a vida examinada e o princípio da autopoiesis .................................... 133

4.1. A Carta VII como um texto filosófico..................................................................... 133

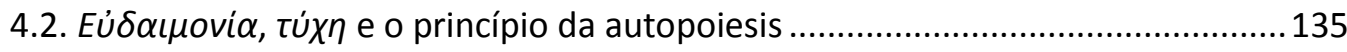

4.2.1. O princípio da autopoiesis na obra de Platão ................................................. 140

4.3. Platão e Dionísio II: o exemplo e o contraexemplo na Carta VII ........................... 142

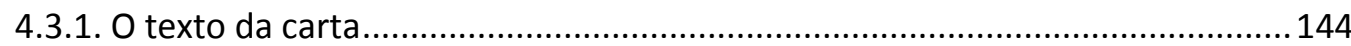

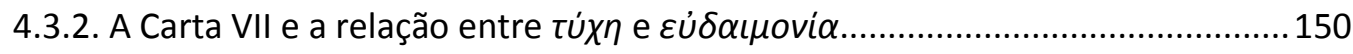

4.3.3. "Esses não sabem nem de si mesmos" ............................................................... 152

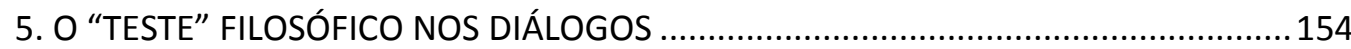

5.1. A Carta VII e a questão do "anonimato" de Platão ................................................. 154

5.2. O contexto dramático dos diálogos como moduladores do conteúdo filosófico 157

5.3. As "passagens de retenção", segundo Thomas Szlezák...................................... 159

5.4. A Carta VII e as condições para o aprendizado da filosofia ..................................161

5.5. Platão revela a existência de um "teste" filosófico................................................. 164

5.7. Breves exemplos: o Laques e o Eutifron ............................................................. 167

5.8. Um caso paradigmático de malogro no teste: Mênon .........................................169

5.9. Um caso paradigmático de êxito no teste: Teeteto...........................................172

5.10. Uma avaliação da ideia dos diálogos como "testes" ........................................ 175

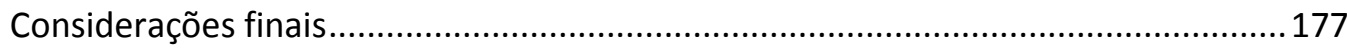

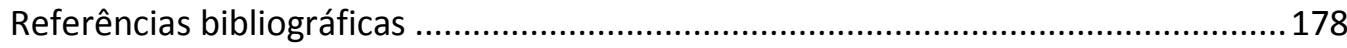




\section{Introdução}

A presente pesquisa tem como objeto de estudo a epístola atribuída a Platão que, desde a edição de Trasímaco, ficou conhecida como a Carta VII. O propósito é o de apresentar uma leitura e uma interpretação desse documento que revelem uma dimensão filosófica além daquela que normalmente lhe é atribuída. A tradição de comentário e interpretação estabelecida desde o século XIX costuma ver na Carta VII um documento de grande relevância historiográfica e uma fonte importante para dados sobre a biografia de Platão - e um escrito que incidentalmente também trata de questões filosóficas na famosa passagem do "excurso" (342a-345c). Defenderemos aqui uma tese diferente: a de que toda a epístola, na medida em que é um relato autobiográfico, tem profundo significado filosófico, já que faz culminar a apropriação socrático-platônica da máxima délfica "Conhece-te a ti mesmo", assim como o preceito da "vida examinada" enunciado na Apologia. É uma obra que, portanto, não apenas atesta a formação de um determinado modo de compreensão sobre o que seja indivíduo humano, na cultura grega em geral, como também expõe muito da posição filosófica de Platão a esse respeito. Além disso, defendemos também que a rara ocasião em que o filósofo escreve na primeira pessoa do singular pode nos ajudar a lançar luz sobre a interpretação dos diálogos, em especial sobre o contexto dramático dessas obras.

O primeiro capítulo da pesquisa se dedica a uma apresentação panorâmica sobre o epistolário platônico, e em especial sobre a Carta VII: o contexto histórico, seu lugar nas compilações da Antiguidade, o assunto de que trata, uma breve exposição da situação política a que o texto se reporta.

O segundo capítulo se reporta à antiga e muito controversa questão da autenticidade da carta. Nele, empreendemos o trabalho de, na medida do possível, organizar os termos da discussão, propondo uma espécie de "tipologia" dos argumentos favoráveis e contrários - os historiográficos, estilísticos, estilométricos e filosóficos. A partir dessa organização, apresentamos uma análise crítica de todo o debate, e terminamos por expor um posicionamento sobre o tema.

Superada a inevitável questão da autenticidade, o terceiro capítulo se dedica a perseguir o tema da gradual formação de uma determinada noção de 
individualidade humana na cultura grega - ou a formação daquilo que Bruno Snell chamou de "noção abstrata de sujeito". Trata-se de uma questão densa e difícil, e por isso a expusemos a partir da leitura e da visão de uma pequena coleção de helenistas - Snell, Schmitz, Dodds, A. A. Long, Cornford. Em seguida, há uma exposição sobre como esse processo de gradual formação se relaciona com o preceito que era exibido no pórtico do Oráculo de Delfos: "Conhece-te a ti mesmo". E, por fim, apresentamos a apropriação desse imperativo como questão filosófica na obra de Platão, de maneira a nele enxergar uma difícil questão a ser investigada - a natureza do "si mesmo" a ser conhecido.

O quarto capítulo se dedica a uma análise da própria Carta VII como um texto que faz culminar todas essas questões, e em que Platão demonstra, no escrutínio e investigação da própria vida, o sentido e a dimensão da investigação de si. Conforme veremos, ele se relaciona intimamente com a própria possibilidade da "autoria de si", ou daquilo que, na falta de um melhor termo, chamamos de princípio da autopoiesis - uma prerrogativa do modo de vida dos filósofos.

O quinto e último capítulo da pesquisa propõe um tema em separado, mas que se relaciona e complementa o restante da pesquisa. Não é nova a ideia de usar o texto da Carta VII como um parâmetro, ou ao menos como um ponto de apoio, para a interpretação dos diálogos. Um texto do filósofo escrito na primeira pessoa é uma preciosa oportunidade de saltar por sobre o problema do "anonimato de Platão", e ter contato com ideias filosóficas com as quais ele próprio, e não os seus personagens, enunciou. Há no entanto uma constante entre as tentativas já empreendidas nesse sentido: elas sempre se atêm à passagem do "excurso" filosófico, e tentam lançar luz sobre o conteúdo dos diálogos. Propomos aqui um trabalho diferente: usar a carta para lançar luz sobre o aspecto dramático dos diálogos. Eis a ideia, em linhas gerais: no texto da Carta VII, Platão expõe claramente quais são os requisitos indispensáveis, intelectuais e éticos, para que um indivíduo possa se dedicar à educação filosófica, e delineia claramente quais foram as razões que o fizeram desistir de educar Dionísio II, tirano de Siracusa. Mais do que isso, revela a existência de um "teste" a ser aplicado a quem se candidata ao aprendizado da filosofia. Esse corpo de critérios pode nos ajudar a ler e interpretar o contexto dramático dos diálogos e seus personagens, especialmente em relação 
àquilo que o intérprete alemão Thomas Szlézak chamava de "passagens de retenção".

Em uma frase, é este o propósito da pesquisa que se segue: colaborar, ainda que modestamente, para a tradição de interpretação da Carta VII, de maneira a dimensionar corretamente a sua relevância como um texto de caráter filosófico. Se, conforme nos parece, essa epístola não ocupa ainda o seu devido lugar na exegese do pensamento de Platão, isso talvez se deva a dois fatores: às dúvidas em relação à autoria e à falta de reconhecimento da sua dimensão filosófica. Vamos nos reportar a ambas as questões nas páginas que se seguem. 


\section{Uma introdução panorâmica à Carta VII}

\subsection{As 13 cartas atribuídas a Platão}

Desde que dispomos de compilações das obras de Platão, a partir do séc. I a.C., os diálogos editados vêm acompanhados de uma série de 13 cartas. Há notícia, dada por Diógenes Laércio, de uma compilação do séc. III a.C. que já as continha (trataremos do tema em maiores detalhes abaixo). São cartas atribuídas a Platão, escritas na primeira pessoa do singular, textualmente dirigidas a pessoas ou grupos identificados, e tratando de temas específicos. Quase todas elas se iniciam com uma saudação que passou a ser conhecida como tipicamente platônica: $\varepsilon \tilde{v} \pi \rho \alpha ́ \tau \tau \varepsilon l v$. Embora a autenticidade dessas cartas como escritos platônicos seja bastante debatida modernamente (e há notícias de especulações a esse respeito desde o séc. $\mathrm{XV})$, trata-se de documentos potencialmente muito importantes: neles teríamos o filósofo escrevendo em contextos não filosóficos, discorrendo sobre assuntos diversos, dando conselhos diretos, reportando-se a questões práticas, muitas vezes de ordem política - um material que poderia nos ajudar a compreender muito a respeito do autor da obra filosófica mais influente da história humana.

A compilação de Trasilo traz 13 cartas, obedecendo a uma ordenação que não parece arranjada por nenhum princípio discernível: não estão agrupadas cronologicamente, nem de acordo com os destinatários, nem tampouco pelos assuntos de que tratam. Diógenes Laércio já propôs rearranjá-las, para fins de estudo, de acordo com os destinatários, o que as separa em três conjuntos distintos:

1. Cartas a Dionísio: I, II, III e XIII.

2. Cartas a Díon, ou a seus amigos e aliados: IV, VII, VIII e XII.

3. Cartas a diversos governantes e pessoas públicas: V, VI, IX, XI e XII.

Além disso, seria possível arranjá-las em ordem cronológica, caso em que a sequência seria: XIII, II, XI, X, IV, III, V, I, VII, VIII, VI. A Carta IX, dirigida a Arquitas, seria bastante difícil de datar, e tudo o que podemos dizer é que seria 
posterior a 378 a.C. - mas, por uma série de razões que não nos cabe aqui enumerar, ela é comumente considerada apócrifa.

\subsection{Contextualização e pano-de-fundo histórico}

Desde já, é digno de nota que oito das 13 cartas, incluindo a que é o tema central desta tese, se dedicam ao tema do governo e dos governantes da Sicília, Díon e Dionísio. É certamente útil, portanto, apresentar um brevíssimo resumo dos acontecimentos políticos da região que afetaram diretamente a vida, e presumivelmente o pensamento, de Platão. Essa contextualização se fará necessária para a compreensão de muitos dos assuntos que serão discutidos posteriormente. Para essa reconstituição dos eventos históricos, nos fiamos não apenas na Carta VII - que, à parte as questões acerca da autenticidade, é considerada fonte confiável para os eventos de Siracusa, conforme teremos ocasião de ver em detalhes mais abaixo -, mas também em outras obras antigas sobre o assunto, como a Vida de Díon, de Plutarco, e o Livro XVI da Biblioteca Histórica, de Diodoro Súculo. Também foram consultados os resumos feitos por autores modernos.

Maior cidade da Sicília antiga, Siracusa era um pólo importante de cultura e comércio do mundo grego. Havia vencido a tentativa de invasão por parte de Atenas em 415-413, e, nos anos seguintes, teve de resistir às tentativas de invasão de Cartago. A assembleia democrática então votou por fazer de Dionísio I, ou

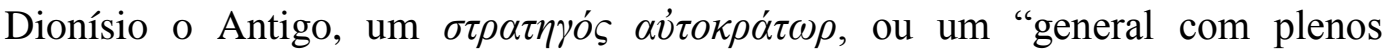
poderes". Mesmo superada a situação de emergência, Dionísio I se manteve como tirano de Siracusa, e reinou por 38 anos.

Nos anos de 388-387 a.C., quando tinha cerca de 40 anos de idade, Platão empreendeu uma primeira viagem à Itália e a Siracusa. Durante essa viagem Platão conheceu o Arquitas, o filósofo pitagórico, e também tornou-se próximo de Díon, cunhado do tirano, então um jovem com cerca de 20 anos - de todos os companheiros de Platão, ele teria se mostrado "o mais presto para aprender e o mais disposto a atender o chamado da virtude”, segundo Plutarco (Capítulo 4, seção 2). 
Os pendores intelectuais e a disposição de caráter do jovem teriam causado boa impressão em Platão, e entre os dois se estabeleceu uma sólida amizade, em torno do entusiasmo pela filosofia e de ideias sobre o bom governo das cidades. Essa amizade perduraria ininterrupta até que Díon fosse assassinado, cerca de 33 anos depois. Foi ao retornar para Atenas dessa visita a Siracusa que Platão fundou a Academia, no ano 387 a.C.

Dionísio I era um tirano ambicioso e empreendedor, e pelos 20 anos seguintes dedicou-se a expandir e a consolidar o seu império pela Sicília e pela Magna Grécia, e em tornar Siracusa tanto um pólo intelectual quanto uma potência militar. Morreu em 367 a.C., e foi sucedido seu filho Dionísio II, ou Dionísio o Jovem, que vai se tornar um dos protagonistas dos acontecimentos que envolverão Platão, e um dos principais temas da Carta VII. Todas as fontes, platônicas ou não, o relatam como um tirano com pendores e disposições bem diferentes das de seu pai, em especial naquilo que diz respeito aos interesses intelectuais e ao desejo de transformar Siracusa em uma capital das letras e do saber. Fontes antigas descrevem-no como incompetente, pobre de discernimentos políticos e, ademais, vaidoso, intempestivo e de vida dissipada. Plutarco relata que logo no início de seu reinado ele promoveu uma espécie de maratona festiva de 90 dias, e que durante todo o período esteve bêbado e não se reportava a nenhuma questão política ou de governo (Capítulo 7, Seção 4). Durante os primeiros anos do seu reinado, ele foi ainda guiado politicamente pelos conselhos e pela tutoria de seu tio Díon, e foi por influência deste que Platão, depois de alguma hesitação, foi convencido a fazer uma segunda visita a Siracusa, já no ano 367 a.C. Presume-se que Platão tenha visto aí a oportunidade de, com a ajuda de Díon, realizar o seu expresso ideal de um estado que fosse governado por um filósofo-rei. Sob o conselho do filósofo, Díon tentou empreender reformas moralizantes e na forma de governo, o que despertou a desconfiança de políticos e nobres, e logo suscitou ruidosa oposição. Além disso, o próprio Dionísio perdeu a paciência com o estilo de vida austero e virtuoso que seu tio, sob o conselho de Platão, tentava impor para os membro da corte, e em especial para o governante. Aos poucos, o jovem tirano passou a dar ouvidos àqueles que questionavam a lealdade de Díon, e o acusavam de tentar usurpar o poder ou de fazer do tirano um mero títere de suas próprias aspirações. Poucos meses depois da chegada de Platão, Díon foi condenado ao exílio, e Dionísio II, a quem ele desejava 
dar treinamento e formação filosófica, passou a demonstrar nenhum interesse em perseguir os árduos caminhos da vida filosófica. Depois de algumas tentativas de interceder por Díon e de convencer o governante, Platão decidiu deixar a Sicília.

Ao longo dos cinco anos seguintes, Platão se manteve interessado nos acontecimentos de Siracusa - entre outras iniciativas, tentou promover um bom entendimento entre Arquitas de Tarento e Dionísio II. Essa intervenção teve como resultado a ajuda siciliana na guerra dos tarantinos contra os lucanianos. Diz-se que, por essa época, embora tivesse recusado os rigores da formação filosófica, o governante ainda tinha o desejo de tirar proveito da sua relação com Platão, e de apresentar-se, seguindo os passos de seu pai, como patrono das letras e como um sábio ele próprio. Cercou-se então de sábios e de sofistas diante dos quais podia exibir sua erudição, e dizer-se um membro comprometido da já prestigiosa Academia de Atenas - sem jamais, no entanto, tomar a iniciativa de repatriar Díon. Por fim, sua ambição de fazer da sua corte uma capital da cultura grega o impeliu a retomar o contato com Platão e a convidá-lo para uma nova estada em Siracusa. Muito embora antevisse não se tratar de uma boa ideia, Platão atendeu ao apelo, em parte por conta dos conselhos de Díon, assim como o de outros amigos, que tinham a esperança de que ainda fosse possível intervir no rumo das coisas, convencer Dionísio a repatriar Díon, e talvez despertar nele o interesse pela filosofia.

Tais esperanças logo viriam a se frustrar, e a terceira visita à Sicília (361360 a.C.) rápido se mostrou um malogro completo. Logo no primeiro encontro, Platão percebeu que o tirano não estava disposto a enfrentar as fadigas envolvidas no aprendizado da filosofia. Além disso, apesar dos mais empenhados esforços, Platão não conseguiu persuadir o tirano a repatriar Díon. Com isso, em pouco tempo a relação entre os dois tornou-se áspera, e Platão foi tomado por desgosto ante os caprichos, a instabilidade e as baixas paixões do governante. E Dionísio, por sua vez, ressentia-se da lealdade de Platão a seu tio expatriado. Por fim, tomado de rancor em relação a Díon, o tirano terminou por confiscar suas propriedades, e afastou-o de sua esposa e seus filhos. Ao mesmo tempo, tratava Platão com ostensivo desrespeito, tornando-o quase que um prisioneiro dentro do palácio real, até o ponto em que o filósofo chegou a temer pela própria vida diante dos maustratos dispensados pelos soldados da corte. Platão foi resgatado dessa situação 
humilhante pela intervenção de seu amigo Arquitas de Tarento, a quem havia feito chegar um pedido de ajuda.

Ao deixar Siracusa pela terceira vez, e antes de seguir para casa, Platão fez uma viagem até Olímpia, onde se encontrou com Díon durante os Jogos, e com ele pôde discutir os acontecimentos e a situação da Sicília. Contra o conselho do filósofo, Díon resolveu-se a mover uma operação militar contra Dionísio, e conclamou amigos e aliados a que se juntassem à empreitada. A investida militar contra Siracusa aconteceu em 357 a.C., e foi recebida com entusiasmo pela população. Não houve muita dificuldade, e a cidade logo foi tomada pelas tropas, embora o tirano tenha conseguido se manter encastelado em seu palácio, na ilha de Ortígia. Mas quando Díon iniciou o seu processo de reformas de governo, acabou por perder o apoio popular, e teve de enfrentar um motim liderado por Heraclides - um almirante fiel ao tirano deposto. Depois de uma série de entreveros, Díon achou por bem condenar Heraclides à morte e executá-lo - e essa iniciativa extrema, em vez de assegurar a paz, logrou apenas aumentar a sua impopularidade e indispor os ânimos populares. Os eventos chegaram ao clímax com um desfecho trágico: Díon foi assassinado em 353 a.C. por Cálipo e seu irmão - dois atenienses que se fizeram passar por seus amigos.

Com a morte de seu líder, os amigos e aliados de Díon se refugiaram em Leontini, enquanto Cálipo mantinha o poder em Siracusa. A situação ainda era muito instável e, pouco depois de um ano, os partidários de Díon, sob o comando de seu sobrinho Hiparino, lograram tomar Siracusa, e passaram a comandá-la, periclitantemente e sob permanente estado de tensão, juntamente com Leontini. O resto da Sicília, ademais, permanecia em estado de guerra civil, e começaram a se suceder incursões e tentativas externas de invasão - cartaginenses e italianos. Em 350 a.C., Hiparino faleceu, e logo depois seu irmão e sucessor Niseu. Em Leontini, o governante Hicetas traiu os partidários e aliados de Díon, e chegou a executar todos os seus parentes que conseguiu alcançar. Neste momento, Platão está nos últimos anos de vida - viria a morrer em 347 a.C., desgotoso com o rumo dos acontecimentos na terra de seu amigo Díon. 


\subsection{Linha do tempo}

Como a carta se apresenta a uma situação política intricada, pretende incidir sobre uma disputa de poder bastante convoluta, e faz referência a três diferentes visitas a Siracusa em momentos e condições bastante diferentes, será útil, para fins de orientação, o fornecimento de uma pequena linha-do-tempo em torno desses acontecimentos ${ }^{1}$.

405 - Dionísio I se torna tirano de Siracusa.

391 - Dionísio I invade a Itália e se alia aos lucanianos.

388 - Primeira visita de Platão a Siracusa.

387 - Platão funda a Academia.

383-378 - Guerra entre Siracusa e Cartago.

368 - Nova guerra com Cartago. Dionísio I envia uma embaixada a Atenas.

367 - Morte de Dionísio I. Início da tirania de Dionísio II.

367-366 - Segunda visita de Platão a Siracusa.

366 - Díon é exilado. Platão ainda se encontra em Siracusa.

361-360 - Terceira visita de Platão a Siracusa.

357 - Díon invade Siracusa e destrona Dionísio II.

354 - Díon é assassinado. Cálipo o sucede como tirano.

354-353 - Data presumível para a redação da Carta VII de Platão.

352 - Hiparino II sucede Cálipo.

351 - Niseu sucede Hiparino II.

347 - Morte de Platão.

346 - Dionísio destrona Niseu e torna-se novamente tirano de Siracusa.

345 - Os siracusanos se aliam aos conríntios para destronar Dionísio II.

344 - Timoleão vai à Sicília.

343 - Timoleão reina sobre Siracusa, até aposentar-se, em 337.

\footnotetext{
${ }^{1}$ Adaptada da linha do tempo de The Cambridge Ancient History, vol. 6, The Fourth Century b.C., de Lewis D. M. et al. (eds). Cambridge: Cambridge University Press, 1994. Foram acrescentadas as datas envolvendo Platão.
} 


\subsection{Carta VII: resumo e roteiro de leitura}

A Carta VII é um texto notoriamente emaranhado, que trata de vários assuntos superpostos, alterna temas e modalidades de discurso, e que constitui ao mesmo tempo um texto autobiográfico, um aconselhamento, uma série de considerações filosóficas e de orientações políticas concretas. São 28 páginas e meia na numeração Stephanus compostas de idas e vindas textuais. Tendo isso em mente, é certamente útil apresentar ao leitor um resumo do seu conteúdo, devidamente caracterizado em partes.

A ocasião em que a missiva é escrita é bastante conhecida: depois do assassinato de Díon, seus parentes e aliados escrevem a Platão, seu antigo amigo e mentor, para pedir conselhos. A resposta a esse pedido é a Carta VII. Passemos, então, ao resumo guiado ${ }^{2}$.

1. Abertura da carta: $323 \mathrm{~d}-326 \mathrm{~b}$. Platão faz menção à carta que foi enviada solicitando sua ajuda. Ele impõe uma condição: que os parentes e companheiros de Díon se mantenham fieis às ideias do falecido amigo. Para esclarecê-las, Platão crê oportuno descrever como as suas próprias ideias se formaram, e de que maneira influenciaram Díon.

2. Início da autobiografia filosófica e primeira visita a Siracusa: $326 b-328 d$. Platão fala sobre sua juventude, sobre as ideias que o animavam, e sobre a Tirania dos Trinta. Relata o impacto sofrido com a condenação de Sócrates, o que o fez afastar-se da vida pública. Concebe o seu projeto de um governo de filósofos. Em 388, a primeira visita a Siracusa. Descreve os costumes corruptos da cidade. Conhece Díon, e ambos se tornam próximos, por conta das afinidades filosóficas. Depois da morte de Dionísio I, foi convencido por Díon a voltar a Siracusa para educar Dionísio II, e assim ajudar a empreender reformas políticas.

3. Segunda visita a Siracusa: $328 \mathrm{~d}-330 \mathrm{~b}$. Em parte constrangido pelo pedido do amigo, Platão empreende nova ida a Siracusa. A viagem logo mostrou-se

\footnotetext{
${ }^{2}$ Para confeccionar o resumo, cotejei minhas próprias anotações com resumos semelhantes de diversas obras, em especial BURY, R. G. "Epistle VII - Prefactory note", in PLATO. Timaeus, Critias, Cleitophon, Menexenus, Epistles. Cambridge: Havard University Press, 1929. IRWIN, T. "Introdução à Carta VII, de Platão", in PLATÃO. Carta VII. RJ: Loyola/PUC-Rio, 2013 e BRISSON, L. "Letre VII - Notice", in PLATON, Lettres. Paris: Flammarion, 2004.
} 
infrutífera: Díon era hostilizado, e em breve foi exilado. Dionísio II, embora tentasse ganhar a amizade de Platão, não mostrava interesse nos estudos filosóficos.

4. Os conselhos aos parentes e companheiros de Díon: 330b-337e. A carta então se reporta ao seu propósito expresso de aconselhar os aliados de Díon. Compara a filosofia à medicina. Platão dá a eles os mesmos conselhos que deu a Díon e Dionísio II: moderação e autocontrole na vida privada, cultivar amizades leais, aliar-se a outras cidades da Sicília. Dionísio não o ouviu e permaneceu rompido com Díon, mesmo depois de repatria-lo. Dois falsos amigos o assassinaram. Aconselha a abolição do despotismo em Siracusa, o estabelecimento de um governo constitucional, de acordo com a lei. Recomenda a clemência e a formação de um conselho legislador cujas leis sejam obedecidas.

5. Terceira visita a Siracusa: 337e-342a. Chegam a Platão notícias de que Dionísio II havia por fim se interessado pela filosofia, e o tirano o convida a voltar a Siracusa. O filósofo hesita, mas aceita. Aplica um "teste" ao chegar, para aferir seu comprometimento, e Dionísio malogra. Platão diz ter tido notícia de que Dionísio publicou um livro com ideias ouvidas de outros, como se fossem ideias originais. Repreende sua imprudência e manifesta reservas quanto a escrever sobre certos assuntos.

6. O excurso filosófico: $342 \mathrm{a}-345 \mathrm{c}$. Ocorre a Platão explicar por que, apresentando uma exposição já feita por ele "muitas vezes". Há nos entes três elementos que dão ocasião ao conhecimento: o nome, a definição e a imagem (a própria apresentação sensível). Os três geram o conhecimento, um quarto elemento. Todos os quatro são distintos do quinto: a realidade mesma. Os três primeiros elementos são mutáveis e relativos, tendem a transmitir qualidades e não o em-si. O estudante que se fia neles não obtém o verdadeiro conhecimento. Só um trabalho laborioso, que envolve convívio e muitas tentativas, e se houver conaturalidade entre o conhecedor e o conhecido, o estudante pode forçar os quatro primeiros elementos (conhecimento, coisa sensível, definições, nome) uns contra os outros, inquirir e refutar, até que brilhe o conhecimento.

7. Fim da terceira visita a Siracusa: 345 c-350b. Platão retoma a narrativa da terceira visita. Dionísio II se recusava a restituir a Díon seus bens. O filósofo ameaça ir embora, o tirano aceita um acordo e logo o descumpre. Mantém Platão 
em prisão domiciliar. Depois da intervenção de Arquitas, o pitagórico, Dionísio o deixa partir.

8. O último encontro com Díon: 350b-351e. No retorno para Atenas, Platão passa por Olímpia, por ocasião dos festivais. Lá ele se encontra com Díon pela última vez. O amigo está ansioso por mover uma expedição militar contra Dionísio, mas Platão nega-lhe apoio, por ter sido um hóspede em Siracusa e por ser contrário ao fomento da discórdia. Ofereceu-se para mediar os conflitos, e ambos recusaram. Díon moveu enfim a expedição. Platão reafirma que em tudo Díon teve sempre o bem comum em mente. Sua morte lançou a Sicília em imensa dor.

9. Conclusão: $351 \mathrm{e}-352 \mathrm{a}$. Os conselhos foram dados, e as razões para toda a ação política de Platão foram expostos. Era necessário esclarecer as coisas, dada a estranheza e a irracionalidade dos acontecimentos.

Para os fins da presente pesquisa, será o usado como referência o texto estabelecido e anotado por John Burnet, publicado ao lado da tradução de José Trindade dos Santos e Juvino Maia Jr., na edição da Carta VII feita pela coleção Bibliotheca Antiqua, da editora Loyola/PUC-Rio. Será também essa a tradução majoritariamente citada, exceto nos casos especificamente mencionados. 


\section{A controvérsia em torno da autenticidade da Carta VII}

\subsection{Apresentação do problema}

No presente capítulo, vamos nos ocupar do tema que inevitavelmente se insinua em todo e qualquer estudo que lide com a Carta VII de Platão: a questão da sua autenticidade. Os propósitos das páginas que se seguem são o de dar uma notícia sobre essa controvérsia - por que ela se justifica, em quais argumentos se assenta etc. E, além disso, também é o propósito das próximas páginas o de apresentar uma análise crítica dessa discussão: contrapor argumentos e respostas espalhados por vários autores, mapear as alegações que se contradizem mutuamente, e assim por diante. No fim, esperamos apresentar uma posição razoavelmente clara em relação a essa polêmica, de maneira que possamos desenvolver os capítulos subsequentes já tendo-a como um problema, para os nossos fins, superado. Em se tratando de uma controvérsia antiga, com séculos de duração e desenvolvimento, as considerações hão de se estender, e talvez desçam a certas minúcias que, segundo cremos, são necessária.

Ao longo desta primeira elaboração, pretendemos cumprir os seguintes propósitos: dar uma notícia histórica a respeito da querela da autoria do documento; categorizar em tipos distintos as razões que levaram estudiosos a aceitar ou a rejeitar a autenticidade da carta; apresentar uma análise crítica desses argumentos, propondo posições ou sínteses razoáveis onde isso for possível; e, por fim, apontar, se não uma posição definitiva do problema, o que seria demasiada ambição para a presente pesquisa, ao menos delinear um modo razoável com que seja possível lidar com o texto para os fins a que esta tese se propõe.

Adiantamos, para fins de esclarecimento preliminar, que será aqui defendida a tese de que não há nenhuma razão definitiva que nos pareça suficiente para rejeitar a Carta VII como um documento da autoria que lhe é atribuída - ou seja, do próprio Platão. Nisso, vamos seguir o princípio metodológico adotado por 
August Boeckh e por Paul Friedländer ${ }^{3}$, segundo o qual é a tese da espuriedade, e não a da autenticidade, que demanda provas definitivas. Em outras palavras: se não temos motivos terminantes para rejeitar um documento como autêntico, é razoável tratá-lo, lê-lo e analisá-lo como sendo da autoria que lhe é atribuída. As razões para a adoção dessa posição serão expostos mais adiante, e devidamente embasados, mas desde já é possível estabelecer que a questão, embora exiba argumentos densos e consideráveis de parte a parte, pode encontrar uma solução prática que torne possível o estudo detido de um documento de importância singular, tanto para a compreensão da filosofia de Platão, quanto para uma análise mais aprofundada do desenvolvimento da cultura grega, e mesmo para o forjamento da noção de individualidade humana, tão presente na cultura ocidental posterior.

Nas páginas que se seguem, depois de uma apresentação introdutória e geral sobre o tema, a discussão em torno da autenticidade da carta vai ser dividida em quatro categorias:

1. os argumentos historiográficos;

2. os argumentos estilísticos (divididos, por sua vez, em dois tipos distintos - que chamamos, à falta de melhores expressões, de "estilo literário" e o "estilo pedagógico");

3. os argumentos estilométricos (importante que não sejam confundidos com os da categoria anterior);

4. por fim, os argumentos filosóficos.

Em cada um dos casos, filólogos, helenistas e especialistas em Platão apresentaram argumentos favoráveis e contrários à autenticidade do texto, e nos pareceu interessante tanto arrolá-los ciosamente quanto analisá-los desde um ponto de vista crítico e analítico - apontando, sempre que possível, as sínteses que naturalmente emergem desse tipo de comparação. Além de uma consideração metodológica preliminar necessária, cremos também que esse estudo pode ser de razoável utilidade para os pesquisadores que pretendam se aproximar de um tema

\footnotetext{
${ }^{3}$ FRIEDLÄNDER, P. Plato - An introduction. Princeton: Princeton University Press, 1969. p. 263.
} 
tão complexo e tão controverso, e que tem suscitado posições e polêmicas tão apaixonadas e peremptórias sobre o tema.

A análise que se segue é tributária dos muitos pesquisadores que se debruçaram sobre o tema e que exploraram a questão com grande minúcia filosófica e filológica. O grupo majoritário de estudiosos favoráveis à autenticidade (ou talvez seja o caso de dizer, de maneira mais precisa: daqueles que não se opõem à autenticidade), e cuja obra será aqui analisada, inclui nomes como os de Charles Taylor, Luc Brisson, Paul Friedländer, R. G. Bury, Friedrich von WilamowitzMoellendorff, Giovani Reale, F. M. Cornford, entre outros. Entre os que se opõem mais decisivamente à autenticidade, é preciso mencionar os nomes de especial peso de Georg Misch, Myles Burnyeat, Michael Frede, Terence Irwin, Julia Annas e Ludwig Edelstein. Embora a análise a que nos propomos aqui não pretenda exaurir todos os argumentos jamais apresentados em favor da autenticidade ou da espuriedade, ela pretende analisar os pontos centrais e de maior controvérsia sobre a questão, de maneira a deixar suficientemente mapeada uma querela particularmente acalorada e que tem sua importância nas considerações que pretendemos desenvolver em seguida.

Por fim: para fins de brevidade, a presente pesquisa vai se referir a quem quer que tenha escrito o texto indiferentemente como "Platão" ou como "o autor da carta".

\subsection{Por que existe uma controvérsia sobre a autoria?}

Logo no início das presentes considerações, é razoável explicar por que razão existe uma controvérsia sobre a autoria das cartas, qual o seu histórico e como se formou. As obras de Platão de que dispomos parecem todas remontar a um conjunto de manuscritos baseados em uma edição feita na Antiguidade - a famosa edição de Trasilo de Alexandria, gramático e astrólogo de Tibério. A sua compilação, organizada em tetralogias, constituiu a referência para as edições medievais e modernas posteriores. Essa divisão em tetralogias parece indicar o 
desejo de arranjar os textos de Platão da mesma maneira que as tetralogias dramáticas do teatro antigo, e Diógenes Laércio nos diz que Trasilo acreditava que Platão já havia composto e publicado os diálogos com esse arranjo (D. L. III, 63). Essa compilação já traz o conjunto de 13 cartas que ainda hoje vemos atribuídas ao filósofo, e em uma posição bastante curiosa - o último escrito compilado, algo como um "último diálogo". Essa posição limítrofe foi mencionada como significativa por alguns autores ${ }^{4}$, onde enxergaram talvez já a intenção de, nesse arranjo, deixar transparecer alguma ambiguidade quanto à questão da autoria. Mas é importante ressaltar que, de maneira certamente significativa, o epistolário não aparece como um apêndice ou como um conjunto à parte de escritos, mas como o último item da nona e última tetralogia, juntamente com outras obras de caráter político - Minos (ou Da lei), Leis e Epinomis. Esse pareamento parece conferir ao epistolário, aos olhos do editor, o estatuto de mais uma das obras de alcance ético, que trata da constituição da pólis, da arte da governança e da legislação. É incontroverso que Trasilo considerava as cartas como autênticas, e que as incluiu entre as $56^{5}$ obras que reputava entre as $\gamma v \eta ́ \sigma l o l$ (ou seja: "de boa procedência" ou “de pura linhagem”), conforme nos transmite D.L. III, 57. Assim como aliás nenhum outro autor da Antiguidade de que tenhamos notícia, conforme veremos abaixo, o editor não pôs em questão a autenticidade das cartas.

Neste ponto, é preciso levar em consideração dois dados de grande importância.

Em primeiro lugar: já era conhecida por Trasilo a existência de obras que circulavam com o nome de Platão, mas que não eram de sua autoria. Não só, aliás, por Trasilo, mas por leitores e estudiosos da Antiguidade: numa formulação significativa, Diógenes Laércio, antes de apresentar uma lista de textos espúrios, diz que "todos são concordes em considerar apócrifos os seguintes diálogos". Como compilador, portanto, Trasilo estava atento a essa questão.

Em segundo lugar: à parte a coleção de cartas, é também verdade que, entre os 35 diálogos que Trasilo compilou como autênticos, há alguns que hoje são

\footnotetext{
${ }^{4}$ V. p.e. BURY, R. G. "Introduction to the epistles", in PLATO. Timaeus, Critias, Cleitophon, Menexenus, Epistles. Cambridge: Havard University Press, 1929. p. 385.

${ }^{5}$ São 56 os diálogos que Trasilo considera autênticos porque ele a trata a República como sendo dez livros diferentes, e Leis como sendo doze. O conjunto de 13 cartas é considerada uma única obra.
} 
unanimemente considerados apócrifos, e outros tantos que são postos sob suspeição. Citemos, a título de ilustração, ambos os Alcibíades, ambos os Hípias, Hiparco, Amantes, Epinomis, Menexeno, Mino, Clítofon, Teages, entre outros (que, não obstante, costumam ser incluídos nas edições contemporâneas das obras completas de Platão). Ou seja: embora atenta à questão da autenticidade, a compilação de Trasilo não é certamente infalível, e não deve ser tomada como prova definitiva de autenticidade ${ }^{6}$.

A questão da autoria das obras de Platão não parece ter sido de grande interesse dos estudiosos até a virada para o século XVIII, e não é reportado maior esforço investido sobre o assunto desde o fim da Antiguidade até o início dos setecentos. Marsilio Ficino, é verdade, fez alguma menção ao problema da autoria do epistolário, e, na sua edição da Platonis Omnia Opera, de 1484, disse crer que a Carta I foi na verdade escrita por Díon, e, incidentalmente, também reputou espúria a Carta XIII ${ }^{7}$. Esse tipo de consideração, no entanto, é antes exceção do que regra na história dos antigos estudos platônicos. Com a renovação do interesse pelos clássicos, e com o pleno desenvolvimento acadêmico da filologia, o tema ganhou fôlego. O classicista R. Bentley publicou, em 1697, um estudo chamado Dissertações sobre as epístolas de Phalaris, em que ele põe em circulação a ideia de que parte significativa das coleções epistolares atribuídas a grandes nomes da Antiguidade eram forjamentos posteriores - e, no entanto, na mesma obra, disse considerar o conjunto de 13 cartas platônicas como inteiramente autêntico.

Numa tendência oitocentista que passou a ser conhecida como a "hipercrítica", estudiosos do texto platônico do século retrasado chegaram a pôr em questão isoladamente a autoria de quase todos os diálogos atribuídos ao filósofo e, além dos diálogos, houve forte tendência de questionar a autenticidade de todas as 13 cartas. Foi essa a posição adotada por Christoph Meiners, Friedrich Ast e H. T. Karsten ${ }^{8}$. Essa tendência foi mitigada a partir já do fim do século XIX, levandose em conta critérios como a reputação dos escritos já durante o período helenístico,

\footnotetext{
${ }^{6}$ Vamos nos deter obre a importância do testemunho de Trasilo e de Diógenes Laércio, assim como de outros testemunhos da Antiguidade, mais adiante nesta mesma tese. Também vamos nos reportar à notícia da existência de outras compilações da obra de Platão na Antiguidade.

${ }^{7}$ V. BRISSON, "Introduction", in PLATON, Lettres. Paris: Flammarion, 2003. p. 72.

${ }^{8}$ V. BURNYEAT, M. \& FREDE, M. The pseudo-platonic seventh letter (org. Dominic Scott). Oxford: Oxford University Press, 2015. p. 7.
} 
a menção e discussão de alguns dos diálogos na obra de Aristóteles, assim como outros testemunhos antigos.

No estabelecimento desse novo paradigma, que de alguma forma equilibra as tendências de aceitação acrítica e da "hiper-crítica", desempenhou papel de grande importância a obra do célebre filólogo alemão Ulrich von WilamowitzMoellendorff. No volume II de sua obra Platon, Wilamowitz diz não apenas considerar a Carta VII autêntica, mas afirma ainda esperar que as discussões acerca da espuriedade estejam "encerradas definitivamente" ${ }^{\text {" }}$. Segundo Paul Friedländer ${ }^{10}$, o posicionamento definitivo e apaixonado do "príncipe dos filólogos" constituiu um argumento de autoridade suficiente para reconfigurar toda a discussão, e inaugurou a tendência majoritária entre os estudiosos de considerá-la como de autoria de Platão (ainda que, como ele mesmo observa, alguns prefiram cautelosamente qualificá-la como "provável autoria de Platão"). Por bastante tempo, de fato, os estudiosos consideravam-na já uma questão encerrada, decidida pela autenticidade, até a publicação da influente obra de Ludwig Edelstein, Plato's Seventh Letter ${ }^{11}$. Nela, o estudioso tomou decidida posição contra a autenticidade, baseado quase que exclusivamente em argumentos sobre o conteúdo filosófico da obra - indigno, segundo ele, da mente de Platão. Desde então, algumas vozes dissidentes a ele se juntaram, em que se destacam as de Michael Frede, Myles Burnyeat, Julia Annas e Terence Irwin. Se a maioria dos estudiosos ainda tende para a tese da autenticidade, as vozes discordantes são fortes, mesmo que minoritárias, e não devem ser desconsideradas.

Conforme já dito anteriormente, especialmente a partir do início do século XX, a discussão se desdobrou a ponto de comportar argumentos de tipos diversos, e em planos variados de consideração. A partir daqui, será necessário organizar essa vasta discussão para orientar o leitor diante dos diversos argumentos arrolados tanto por defensores da autenticidade quanto pelos partidários da espuriedade. Depois de exaustiva análise, concluímos pela existência de quatro pontos principais de controvérsia: os historiográficos, os estilísticos, os estilométricos e os que dizem

\footnotetext{
${ }^{9}$ WILAMOWITZ-MOELLENDORFF, U. von. Platon, vol. 2. Berlim, 1920. pp. 281 ss.

${ }^{10}$ Op. cit., p. 236.

${ }^{11}$ EDELSTEIN, L. Plato's Seventh Letter. Leiden: E. J. Brill, 1966.
} 
respeito ao conteúdo filosófico das cartas. Passaremos agora a uma análise de cada um deles.

\subsection{Uma tentativa de organização tipológica dos argumentos em torno da questão}

No estudo e na análise tipológica de argumentos que se seguem, foram de grande valia algumas obras de referência a respeito do epistolário de Platão e da Carta VII em particular. Desde já, é preciso mencionar, especificamente, as obras de Paul Friedländer, de M. Frede e M. Burnyeat, de Ludwig Edelstein, de G. R. Bury, de A. E. Taylor, de Terence Irwin e de Luc Brisson. No ensaio que este último encartou como introdução à sua edição das 13 cartas, há também uma sucinta tipologia que argumentos, embora organizada de maneira bem diferente e dando enfoque a questões outras - e que, no entanto, serviram de referência para as páginas que se seguem.

\subsection{Os argumentos historiográficos}

Os argumentos historiográficos que podem ser usados em favor ou em contrário da autenticidade da Carta VII são de tipos bastante diversos, e algumas questões relevantes que se impõem são: se o gênero epistolar já existia e se estava bem estabelecido nos tempos de Platão; se existem testemunhos antigos que mencionem a carta; se os fatos ali relatados, especialmente no que concerne à história de Siracusa no século IV a. C., são fidedignos; que tipo de credibilidade pode ser atribuída às cartas assinadas por grandes nomes da Antiguidade, e a partir de quais alegações, entre alguns outros. Passemos a eles. 


\subsubsection{Sobre a existência do gênero epistolar}

Ao que tudo indica, o gênero epistolar começou a se desenvolver na Grécia Antiga juntamente com a disseminação da escrita alfabética, a partir dos séculos VII e VI a. C. Temos prova de que o gênero já era conhecido e praticado no século V a. C. pelas obras de Heródoto e de Tucídides, que não apenas mencionam correspondências entre os personagens de que tratam, mas chegam mesmo a reproduzir integralmente o texto de algumas missivas. No Livro III de sua História, por exemplo, Heródoto transcreve literalmente uma carta enviada por Amásis a Polícrates, rei de Samos, e em seguida relata toda a fortuna da correspondência entre ambos (III, 40-43). No Livro V (14), dá notícia de uma carta enviada por Dario a Megábazos. No Livro VI, menciona cartas de Histíaios aos persas que se encontravam em Sárdis, como parte de uma trama conspiratória que resultou na morte de inúmeras pessoas (VI, 4). É preciso aqui lembrar que, se autêntica, a Carta VII teria sido escrita pouco depois de 354 a. C.. Como a História de Heródoto foi composta por volta do ano 440 a. C., e faz referência a fatos e eventos ainda anteriores, ela dá testemunho da existência de um gênero consolidado mais de cem anos antes.

Também Tucídides menciona correspondências e epístolas como coisa banal e corriqueira: no Livro VII de sua História da guerra do Peloponeso, conta que o general Nícias, em viagem, e com medo de que certas instruções suas acabassem deturpadas caso fossem transmitidas oralmente, enviou uma série de cartas aos atenienses, seus comandados (III, 8). Há então um relato curioso: o escriba da cidade teria lido uma dessas epístolas, particularmente importante, do alto de uma tribuna para "todos os atenienses" (III, 10). O longo texto da carta é então reproduzido na íntegra por Tucídides, o que toma cinco capítulos do livro. O episódio é digno de especial menção porque atesta também a existência da prática das "cartas abertas" (assunto que desenvolveremos mais abaixo), e mostra que tipo de tratamento esse texto podia receber - no caso, uma leitura pública, marcante o suficiente para que o seu conteúdo fosse registrado e legado à posteridade. Para todos os fins, no caso da carta do general Nícias, tratou-se quase que de um "discurso feito à distância", escrito por ele mas lido em voz alta, a partir da tribuna, para um grande público. Exploraremos a importância desse ponto em seção 
posterior do presente capítulo. Por fim, no Livro VIII, o historiador relata que Astíoco foi avisado de uma conspiração por meio de uma cara enviada por Pedáritos. Mais adiante, novamente há o relato de uma convoluta conspiração, envolvendo Astíoco e Alcibíades, e que envolveu cartas secretas passadas de mão em mão e lidas por diversas pessoas interessadas (VIII, 50-51).

Tais relatos são particularmente importantes pela seguinte razão: não apenas atestam a banalidade da prática epistolar entre as pessoas letradas, mas, especialmente, um uso desse recurso literário em circunstâncias notavelmente semelhantes às da Carta VII de Platão: um mentor que passa instruções aos seus mentorados, num contexto de conspirações palacianas, e conclamando a uma determinada ação política. Atestam também, o que aliás é bastante verossímil, que o texto de uma epístola pública de tal teor poderia ser preservado, possivelmente mediante cópias. Aqui, para os nossos fins, pouco importa que os textos reproduzidos por Heródoto e Tucídides sejam ou não fidedignos - importam antes o testemunho e a intenção da preservação.

À parte as obras de Heródoto e Tucídides, de fato são poucas as cartas, individuais ou em coleção, que nos chegam dos séculos V e IV a. C. Daquelas que restaram, apenas as de Platão e as de Isócrates são seriamente consideradas como candidatas à autenticidade. Há algumas cartas atribuídas a Aristóteles, sobre as quais há pouca discussão significativa, e uma carta atribuída a Espeusipo e endereçada a Filipe II da Macedônia, que costuma ser tida como autêntica ${ }^{12}$. Algum tempo depois, temos as três cartas de Epicuro reproduzidas por Diógenes Laércio, também pouco questionadas. Tal escassez de casos outros que os de Platão poderiam levantar suspeitas, mas há também bons argumentos a serem considerados (ver o item 3 abaixo, nesta mesma seção).

${ }^{12}$ V. BRISSON, op. cit., p. 13. 


\subsubsection{O testemunho de Diógenes Laércio, e os testemunhos indiretos de Trasilo e de Aristófanes de Bizâncio}

Conforme já mencionado, nos manuscritos de Platão compilados na Antiguidade, a coleção de 13 epístolas foi posta como um componente da última tetralogia, segundo o arranjo de Trasilo, do séc. I a.C. Embora a edição de Trasilo tenha se tornado um parâmetro, sendo aliás a coleção de onde retiramos a numeração canônica das cartas, é relevante mencionar que Diógenes Laércio faz menção a uma edição ainda mais antiga, feita por Aristófanes de Bizâncio. Essa compilação, arranjada em trilogias, embora só contenha alguns dos diálogos de Platão (todos, hoje, unanimemente considerados autênticos, exceto, talvez, o Epinomis), incluía também a coleção de cartas (D. L. III, 61-62). A rigor, não temos como saber se as cartas da edição de Aristófanes eram as mesmas do epistolário de que hoje dispomos, se uma ou mais delas estavam ausentes, ou se havia algum texto que hoje desconhecemos - A. E. Taylor afirma taxativamente que eram as mesmas, sob o argumento de que, se fossem outras, "teríamos ouvido mais sobre esse assunto" ${ }^{13}$. Fato é que essa alusão à compilação de Aristófanes de Bizâncio, feita muito provavelmente ao longo do séc III a. C., é a notícia mais antiga que temos de um testemunho externo que mencione a existência de cartas escritas por Platão. É verdade que alguns estudiosos quiseram encontrar uma alusão à Carta VII na obra Elementa harmônica, de Aristoxeno de Tarento - a mesma obra em que há o testemunho sobre a preleção "Sobre o Bem" -, mas essa suposição é bastante incerta $^{14}$.

O mesmo Diógenes Laércio é um testemunho bastante importante, vindo ainda da Antiguidade, sobre a maneira como as cartas de Platão circulavam, e sobre como eram lidas e recebidas. No parágrafo 9 do Livro III, menciona uma carta (de que hoje não temos outra notícia) em que Platão pede a Díon que adquira obras do pitagórico Filolau. Dos parágrafos 18 ao 23 do mesmo livro, apresenta resumidamente os episódios envolvendo o tirano de Siracusa, e parece tomar como fonte as Cartas VII e VIII, embora não as cite explicitamente. Mais do que isso, nos parágrafos 21 e 22, reproduz uma carta que teria sido enviada por Arquitas a

\footnotetext{
13 TAYLOR, C. Plato: the man and his work. NY: Dover Publications, 2001. p. 16.
}

${ }^{14}$ BRISSON, L. "Introduction" in PLATON, Lettres. Paris: Flammarion, 2004. p. 12. 
Dionísio, em que o filósofo pitagórico intercede por Platão e roga pela sua liberação, nos episódios envolvendo a última visita a Siracusa.

Ao tratar do conjunto de obras e das edições, Diógenes Laércio nos diz que Trasilo distinguiu entre os escritos autêntico e os espúrios, sem menção de que houvesse discussão alguma sobre o epistolário. É ainda digno de registro que Diógenes mencione um grupo de escritos que "os críticos" (não nomeados) consideravam como espúrios (Mídon ou O criador de cavalos, Eríxias ou Erasístrato, Alcíon, Acéfalo ou Sísifo, Axíoco, Feácios, Demôdocos, Quelidon, O sétimo dia e Epimenides), e nenhuma menção seja feita a uma discussão que envolvesse o conjunto de epístolas. Afirma, ademais, que as cartas eram "em número de 13, éticas" (III, 61), novamente sem registro da existência de nenhuma controvérsia quanto a isso. Por fim, faz menção à saudação com que as cartas são iniciadas (ê̂u práttein), e as compara com as saudações de Epicuro e Clêon; apresenta uma classificação das epístolas em relação aos seus destinatários; e registra que é essa a classificação adotada "por Trasilo e por outros autores", cuja identidade não chega a revelar.

Se é verdade que editores antigos e medievais não viam maiores problemas em compilar entre as obras completas alguns escritos de autoria duvidosa, e ainda que aquilo mesmo que se entende por "autoria" tenha sofrido certa oscilação ao longo dos séculos, conforme arranjos culturais diversos e suas diferentes compreensões do que fosse a "originalidade", é também igualmente verdadeiro que a questão da autenticidade já era um tema, e o Vidas e doutrinas dá claro testemunho disso.

É importante ressaltar que o texto de Diógenes Laércio nunca jamais se abstém de registrar a existência de polêmicas ou de controvérsias que circulassem sobre a autoria tanto de obras quanto de cartas - e, na verdade, o autor parecia ter um certo pendor para o registro de opiniões divergentes sobre esses assuntos. Em inúmeras ocasiões ao longo de Vidas e doutrinas, ele faz questão de consignar mesmo a existência de uma única voz que divirja sobre a autenticidade de um livro ou texto. Se é verdade que a autoria ilustre para uma carta pode pô-la sob suspeição, uma vez que aumentam os motivos e portanto as chances de um forjamento (questão que exploraremos mais abaixo), é também verdade que, ao tratar de epístolas assim, 
o compilador registra sua suspeição ou descrédito sempre que a ocasião se apresenta. Veja-se o exemplo de uma carta atribuída a Télauges, filho de Pitágoras, e enviada a Filolau, no relato sobre a vida de Empédocles (trad. Mário da Gama Kury): "Não se diz, todavia, de que filósofo pitagórico Empédocles foi ouvinte, porquanto a carta atribuída a Télauges, segundo a qual ele teria ouvido Hípasos e Brontinos, não é fidedigna.” (D. L. VIII, 55).

O testemunho de Diógenes Laércio certamente não nos obriga a uma aceitação acrítica do epistolário platônico, e ganha importância justamente na medida em que não registra em nenhum momento nem mesmo a mera existência de uma polêmica sobre a questão. Tal testemunho é suficiente para supormos que a polêmica sobre a autoria das cartas, e em especial da Carta VII, provavelmente inexistia na Antiguidade.

\subsubsection{Os testemunhos de Cícero, de Pomponius Atticus, de Plutarco e de Luciano}

As menções de Cícero às cartas de Platão são de especial importância para a nossa pesquisa. Em primeiro lugar, é relevante a maneira como as cita, como sendo de amplo conhecimento do público, e sempre supondo a familiaridade do leitor com o epistolário - também sem nenhuma menção a controvérsias sobre a autoria. Apenas como um exemplo, em De finibus (ii. 14), ao citar a Carta IX, diz apenas: "conforme escreveu Platão a Arquitas" (ut ad Archytam scripsit Plato). Também em De officiis (i.7), faz alusão ao princípio platônico de dependência do indivíduo em relação à pólis e a seus deveres diante dela, e alude à Carta IX com um simples "conforme escreveu admiravelmente Platão" (ut praeclare scriptum est a Platone). Em ambos os casos, Cícero se refere ao fato de que "o indivíduo não nasce para si apenas, mas para a cidade" - uma ideia que reputa de capital importância no pensamento político de Platão. É significativo que o filósofo romano prefira citar essa ideia retirada da carta a aludir a ideias correlatas, pretensamente muito mais célebres, presentes na República ou em Leis, por exemplo. 
As alusões de Cícero às cartas de Platão são relevantes não apenas por fornecer um vislumbre sobre o fato de que as cartas eram amplamente conhecidas em seu tempo, mas também pela forma como são lidas e interpretadas. Cícero atribui ao epistolário, e em especial à Carta VII, uma importância filosófica que a maior parte dos intérpretes e comentadores, especialmente os contemporâneos, negligencia. Voltaremos ao tema mais adiante nesta pesquisa.

Mencione-se ainda que Titus Pomponius Atticus, amigo próximo de Cícero e seu correspondente, produziu em Roma, no séc. I. a.C., a uma nova compilação das obras de Platão, e nelas novamente incluiu o conjunto de 13 cartas. Depois dele, e nos primeiros decênios da nossa era, Plutarco faz referências explícitas às cartas III, IV, VII e XIII, ao escrever sobre a história de Siracusa, e Luciano cita o início da Carta III ao fazer menção à célebre saudação ê̂ práttein em sua obra Pro lapsur inter salutandum (3-5).

Tais testemunhos sobre a existência de cartas escritas por Platão são relevantes e devem ser levados em consideração. Alguns estudiosos chegaram a manifestar incômodo com a ausência de qualquer menção ao epistolário nas obras de Aristóteles e naquilo que nos resta dos escritos dos acadêmicos das primeiras gerações, mas, especialmente se levarmos em conta o estado fragmentário destes últimos, e o fato de dispormos de algo em torno de um terço apenas dos escritos aristotélicos, o fato talvez não seja de maior importância - nesse caso em especial, a "ausência de provas" de fato não parece constituir uma "prova de ausência". O fato é que, dos testemunhos efetivamente existentes, algo se impõe de maneira definitiva: ao fim do século III a. C., ou seja, pouco mais de cem anos depois da morte de Platão, uma coleção de cartas já era atribuída ao filósofo e compilada entre os seus escritos. E, além disso, alguns decênios depois, esse conjunto de cartas era largamente citado, por autores que supunham amplo conhecimento dos textos, sem que nenhuma notícia nos seja dada a respeito de objeções à sua autoria. 


\subsubsection{Uma questão historiográfica controversa: o estatuto das cartas da Antiguidade}

A questão da autenticidade das cartas que nos chegam como sendo de autoria de grandes nomes da Antiguidade constitui um problema à parte, especialmente controverso, e que merece aqui uma consideração especial. Não se trata do mesmo problema que encontramos com as demais obras antigas - no caso, os próprios diálogos de Platão ou os tratados de Aristóteles, por exemplo. R. G. Bury assim resumiu a questão ${ }^{15}$ :

No caso das cartas puramente privadas (...) temos de consignar uma razão para a sua preservação. Teria o autor guardado uma duplicata de suas cartas? $\mathrm{Ou}$ as teria o receptor arquivado e preservado? E se algumas foram assim preservadas, por que não todas? Então justifica-se que se duvide a priori da autenticidade de cartas privadas a não ser que haja abundante evidência em seu favor. E ainda mais porque é fácil explicar a origem de cartas espúrias; pois temos, sob a autoridade de Galeno, que altas somas eram pagas pelas bibliotecas por cartas que trouxessem assinaturas ilustres. Essa circunstância recompensava com um prêmio as falsificações; de maneira que valia a pena, para um inescrupuloso homem letrado, estudar o estilo de um autor como Platão com vistas a fazer passar por autêntica uma carta plausivelmente forjada.

E o problema não se restringe ao opulento comércio de manuscritos, mas também se agrava se levarmos em conta a existência, já desde o período clássico, de escolas dedicadas a ensinar a arte da expressão verbal, sob forma de discurso oral a ser proferido em público ou sob a forma escrita ${ }^{16}$. Com o tempo, a distinção entre um $\lambda \dot{o} \gamma o \varsigma$ e uma $\dot{\pi} \pi \imath \tau o \lambda \dot{~ t a l v e z ~ t e n h a ~ s e ~ d i l u i ́ d o ~ e m ~ t e r m o s ~ d e ~ e n s i n o ~}$

\footnotetext{
${ }^{15}$ Op. cit., p. 391.

${ }^{16}$ V. o capítulo 4 da Parte I de MARROU, H-I. História da educação na Antiguidade. SP: Editora da Universidade de São Paulo, 1969.
} 
escolar ${ }^{17}$. As razões para isso seriam muitas: os próprios discursos falados passaram a ser previamente escritos por seus autores; muitos discursos proferidos em público ganhavam depois registros escritos por parte de copistas, qualquer que seja o seu grau de acuidade, como foi o caso da própria Apologia de Sócrates; e, independentemente disso, o hábito dos antigos era o de ler textos literários em voz alta. De qualquer forma, a partir do período helenístico e com a supressão das práticas da pólis democrática, as escolas de retórica passaram a se dedicar tanto à forma escrita quanto à forma oral ${ }^{18}$. Era comum então a prática de exercícios de emulação do estilo de antigos mestres, assim como o forjamento de escritos em que o autor se punha ficticiamente em uma situação histórica - como por exemplo em um exercício em que Sólon fizesse o elogio das próprias leis, ou em que Sócrates reapresentasse sua defesa diante do tribunal ${ }^{19}$. Tais escritos poderiam, mesmo que de boa fé, ser tomados como genuínos algum tempo depois - o que, mesmo suposta a tal boa fé, seria uma operação lucrativa para comerciantes de livros e interessante para os estudiosos e historiadores, já que poria à sua disposição mais uma obra a ser estudada. E haveria ainda, claro, não só no caso das cartas mas no caso de obras em geral, a ocorrência de pessoas interessadas em atribuir especial autoridade a certas ideias e instruções - o que leva filólogos contemporâneos, por exemplo, a ver razão para questionar a autenticidade de algumas das cartas atribuídas ao apóstolo Paulo e a toda a obra atribuída a Dionísio Pseudo-Areopagita (neste último caso, cartas e tratados). Fato é que, qualquer que seja a razão, conjuntos de cartas antigas atribuídas a personagens famosos têm nos últimos séculos não apenas sido questionados, mas peremptoriamente rejeitados como fabricações ulteriores.

No caso específico de cartas assinadas por filósofos gregos, temos toda uma galeria de obras forjadas: as epístolas atribuídas a Heráclito, Demócrito, Sócrates, Aristóteles, Espeusipo, Crates, Diógenes de Sínope, entre outros ${ }^{20}$. Mas há também, é claro, o caso de epístolas quase unanimemente consideradas autênticas, como por exemplo as três cartas de Epicuro reproduzidas por Diógenes Laércio no Livro X do Vidas e doutrinas. O estatuto diferente das cartas de Epicuro se deve a razões bastante sólidas: os textos trazem importantes ensinamentos para os seus discípulos,

\footnotetext{
${ }^{17}$ BURNYEAT, M. \& FREDE, M. The pseudo-platonic seventh letter (org. Dominic Scott). Oxford: Oxford University Press, 2015. p. 12.

${ }^{18}$ MARROU, H-I. Op. cit, p. 307.

${ }^{19}$ MARROU, H-I. Op. cit, pp. 318 e 319.

${ }^{20}$ BURNYEAT, M. \& FREDE, M. Op. cit., p. 12.
} 
e há no próprio texto instruções para que o escrito seja preservado e mesmo "guardado na memória" (D.L. X, 35; D.L. X, 84).

Todas essas nuances devem ser propriamente observadas no caso das epístolas de Platão, e em especial da Carta VII. Trata-se, ao fim e ao cabo, de uma carta privada, caso em que as reservas expressas por Bury seriam cabíveis? Ou tratase antes de uma "carta aberta", um documento público e de maior circulação, o que a aproximaria do estatuto dos diálogos e demais tratados escritos na época? Teria ela uma importância doméstica e privada ou pretenderia ela incidir sobre um debate mais amplo? Não poderia ela ser lida como uma espécie de declaração aberta de intenções, tanto sobre a filosofia platônica quanto sobre os propósitos da Academia, e um atestado de continuidade entre pensamento e vida vivida? Não traria também pontos importantes de ensinamento e doutrina, e que a tornariam importante o bastante, aos olhos dos discípulos, a ponto de justificarem a preservação?

Tais questões são de especial interesse, mesmo porque podem ajudar a apresentar um critério que distinga, entre as 13 cartas de Platão, aquelas que têm maior e menor probabilidade na direção da autenticidade. A distinção entre cartas com destinatário privado e "cartas abertas" se apresenta aqui como um critério de destacada importância, pelas razões já aludidas. A mesma distinção é comumente aplicada na análise das cartas tradicionalmente atribuídas a Isócrates, contemporâneo de Platão: aquelas que são geralmente consideradas autênticas são as que apresentam a forma de um manifesto, uma obra pública - que, embora endereçadas a um interlocutor específico, tinham a clara intenção de serem lidas não apenas por ele, mas por outros leitores.

É fácil perceber como, no epistolário de Platão, algumas cartas têm o caráter de escritos dirigidos a destinatários particulares, como aquelas que saúdam Dionísio (I, II, III e XIII), ou aquelas dirigidas ao pitagórico Arquitas (IX e XII) - e, nesses casos, ainda restaria algum espaço para debate sobre se seriam ou não pensadas como cartas abertas. No caso, entretanto, da VII, a intenção de se apresentar como uma "carta aberta" já se faz manifesta na própria saudação: ela é dirigida "aos parentes e companheiros de Díon”, ou seja, a um grupo não inteiramente definido

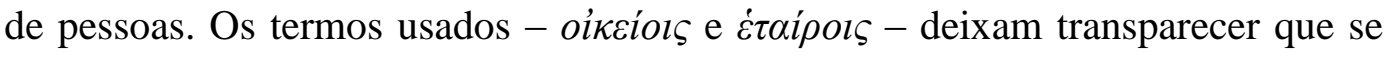
trata, especialmente no segundo caso, daqueles que estejam aliados à causa do 
falecido Díon e a seus ideais. O primeiro parágrafo já deixa claro que o autor não sabia exatamente quem eram tais pessoas, mas que as tratava coletivamente como potenciais aliadas diante das circunstâncias políticas. Só isso já mostra que o texto que se seguirá deveria ser lido por um grupo de pessoas, presumivelmente grande, que ela circularia por várias mãos, e que talvez fosse lida em público. Essa circunstância já é suficiente para que seja razoável supor que cópias tenham sido feitas já em um primeiro momento, o que tornaria bem mais verossímil a possibilidade de preservação do documento. Além disso, o próprio teor do escrito ganha claramente os contornos de um manifesto, um tratado sob a forma de carta, o que já denotaria, por parte do autor, independentemente das providências tomadas pelo destinatário, a intenção de fazê-la circular de maneira mais ampla.

Além disso, uma análise cuidadosa do texto e de certos usos linguísticos parece revelar a intenção do autor de se dirigir a um público amplo e indefinido, ainda maior do que apenas os "parentes e companheiros de Díon”. Se o propósito do texto é o de justificar a presença de Platão em Siracusa, o de fazer uma apologia pro vita sua, e mesmo o de apresentar uma defesa diante de uma série de acusações que circulavam livremente, e às quais aliás o autor faz abundantes menções, é natural que assim fosse. O filólogo H. T. Karsten, em seu Commentatio Critica de Platonis Quae Feruntur Epistolis, de 1864, lista alguns dos indícios linguísticos que atestam que o texto parece dirigido ao público em geral, e não apenas aos "parentes e companheiros de Díon"21: o uso da expressão "não será indigno ouvila [a explicação que será dada], sendo jovem ou não" (324b); o "quem se interessar poderá ouvir isso a seguir" (337e); o "Depois discorrerei sobre isso aos que perguntam por que deliberadamente fui pela segunda vez [a Siracusa]" (330c); e as ocasiões em que os parentes e aliados de Díon são referidos, não na segunda pessoa, como seria natural numa carta a eles dirigida, mas na terceira (333c-d e 334c).

Além disso, o teor propriamente filosófico do escrito - não apenas no excurso, mas, como vamos argumentar, em todo o relato do início ao fim do texto - faz com que ele possa ser de fato considerado uma obra para a edificação de pessoas interessadas no pensamento de Platão, especialmente no que diz respeito ao modo de viver e praticar princípios filosóficos e, conforme veremos, de devotar-

\footnotetext{
${ }^{21}$ Apud BURNYEAT \& FREDE, p. 136, nota 4.
} 
se concretamente aos preceitos da "vida examinada" e da máxima "conhece-te a ti mesmo". Seja como for, trata-se de um ponto incontroverso: todos os estudiosos que se dedicaram a analisar a questão reconheceram que se trata de uma "carta aberta" ou de uma obra pública, pensada para circular amplamente. E tal caráter de "carta aberta", dirigida na verdade ao público em geral, também ajuda a explicar alguns pontos que já foram observados por alguns comentadores: por que relatar a história de Siracusa para os próprios siracusanos ${ }^{22}$ ? Será verossímil que Platão criticasse de maneira tão desabrida os costumes dos sicilianos em uma carta endereçada a eles próprios ${ }^{23}$ ? Será igualmente verossímil crer que os "parentes e aliados" de Díon realmente solicitaram conselhos e guiamento a Platão? Uma carta de tal teor realmente chegaria a seu destino ${ }^{24}$ ? Caso se trate, como tudo indica, de uma "carta aberta", dirigida a um público amplo, tais questões restam já respondidas.

Feitas tais ponderações, é natural que possamos considerar a Carta VII como tendo, nesse sentido, uma condição semelhante às demais obras de Platão, em termos de difusão e de chances de preservação. Nisso, estamos de acordo com Bury, que diz que uma carta aberta "tem em grande medida o mesmo estatuto de um diálogo ou de um discurso" (p. 390). Essa circunstância, portanto, parece resolver a questão das razões da preservação de um escrito com forma de carta - mas não se reporta, no entanto, à possibilidade de uma falsificação, quaisquer que fossem as intenções. Essas questões terão de ser examinadas sob outros aspectos - por exemplo, critérios estilísticos ou estilométricos da obra, a serem analisados mais adiante.

Resta, por fim, lidar com a estranheza ${ }^{25}$ : por que, de todas as epístolas antigas, as de Platão estariam entre as raríssimas preservadas acuradamente? Por que nos restariam apenas as suas cartas e mais algumas outras, como as de Isócrates e de Epicuro? A resposta a essa questão corre o risco de esbarrar no óbvio: Platão é o único autor de toda a Antiguidade pagã cuja obra chega até nós na integralidade. Isso não há de ser um acidente ou um lance do acaso: atesta o êxito obtido pela obra já na Antiguidade, um cuidado na preservação dos manuscritos que parece própria

\footnotetext{
${ }^{22}$ Ambas as questões são registradas por BURY, op. cit., p. 473.

${ }^{23}$ EDELSTEIN, op. cit., p. 11.

${ }^{24}$ Ambas perguntas registradas em BURNYEAT \& FREDE, op. cit., p. 141.

${ }^{25}$ Manifestada por Frede em BURNYEAT \& FREDE, op. cit., p. 11.
} 
dos autores que dispunham de discípulos ou leitores devotados, assim como uma difusão dos livros suficiente para que houvesse cópias que sobrevivessem à dissipação dos tempos e a eventos como a destruição da Biblioteca de Alexandria. A pergunta “por que apenas as cartas de Platão?" é tão cabível e tão respondível quanto a pergunta "por que apenas as obras completas de Platão?"

\subsubsection{A questão historiográfica interna: são fidedignos os fatos descritos na Carta VII?}

A pergunta que intitula esta seção pode ser respondida de maneira bastante simples e direta: por tudo o que sabemos, sim, são fidedignos os fatos históricos sobre Siracusa relatados na Carta VII. As fontes de comparação de que dispomos são algo escassas, mas suficientes para que uma comparação possa ser feita. Os principais historiadores a respeito dos eventos da Sicília do séc IV a. C. são bastante posteriores - Cornélius Nepos (110 a.C. - 25 d.C.), Diodoro da Sicília (90 a.C. 30 a.C.) e Plutarco (46 d.C. - 120 d.C). E, quanto a eles, há uma questão a ser considerada: o próprio Plutarco toma as cartas de Platão como fonte historiográfica, e aliás as cita com alguma frequência; não sabemos se, mesmo sem citá-la, os demais historiadores também a tomaram como referência. Mas é certo que os três também tomam outros autores dos séculos IV e III a.C. como referências, e nós dispomos ainda hoje de alguns fragmentos das obras desses autores. Se, por um lado, em tais fragmentos os historiadores mais antigos não citam a carta atribuída a Platão, por outro tampouco há alguma contradição entre os fatos que narram e aqueles presentes na $\mathrm{VII}^{26}$.

A acurácia historiográfica da carta não chegou nunca a constituir um argumento forte em favor da sua autenticidade. Os partidários da espuriedade a consideram um fato banal: um forjador próximo de Platão estaria tão familiarizado quanto ele com o desenrolar dos eventos políticos de Siracusa; um forjador distante só precisaria se informar a respeito deles, em alguma das obras disponíveis na sua

\footnotetext{
${ }^{26}$ Sobre toda essa questão, ver BRISSON, op. cit., pp. 16-19, e a introdução de Morrow em Plato's Epistles. Indianápolis: Bobbs-Merrills, 1962.
} 
época. Edelstein e Irwin, dois dos que defendem que a carta é apócrifa, simplesmente dizem que, sendo os fatos suficientemente fidedignos, provas em favor ou contrárias à epístola devem ser buscadas em outros critérios ${ }^{27}$. Tampouco os partidários da autenticidade jamais a alegaram como argumento decisivamente favorável, por demasiado banal.

Quanto a isso, apenas uma observação precisa ser registrada. Michael Frede $^{28}$ enxerga uma discrepância entre as descrições de Díon contidas na VII e em fontes externas - vê-o descrito em termos positivos demais no documento, o que seria indício de que talvez a carta tivesse sido escrita por algum aliado político ou por alguém com interesses diretos em favorecer o grupo que se dizia seu herdeiro. Em 336a-b, o amigo de Platão é descrito como "justo, corajoso, prudente e filósofo". As fontes exteriores à carta, no entanto, não registram que Díon jamais tenha tido nenhum interesse pela filosofia, ou que fosse um homem de estudos, ou qualquer coisa que não um político de carreira e profissão ${ }^{29}$. A questão soa demasiado tênue, e muito repleta de questões em torno de juízos valorativos, para que realmente constitua uma objeção a ser respondida. Platão e Díon eram amigos desde que este último era um rapaz, e cultivaram essa amizade até o episódio da conspiração que o assassinou. A Carta VII é também um panegírico de Díon, e uma exortação a que seus ideais não sejam esquecidos. O tom laudatório é não apenas compreensível, mas mesmo esperado - e dificilmente seria possível dizer que constitui um conflito factual de caráter historiográfico.

\subsection{Os argumentos estilísticos}

Um dos pontos de controvérsia em torno das cartas em geral, e da Carta VII em particular, diz respeito ao estilo da obra. Um exame acurado dessa disputa em particular revela rapidamente que sob ela se misturam e se confundem questões diferentes, mas cuja distinção raramente é devidamente apresentada pelos debatedores. Vamos tentar distingui-las devidamente nas próximas páginas,

\footnotetext{
${ }^{27}$ IRWIN, op. cit., pp. 26-67 e EDELSTEIN, op. cit., p. 2.

${ }^{28}$ Op. cit., pp. 78 ss.

${ }^{29}$ Op. cit., pp. 80-81.
} 
agrupados em argumentos sobre o estilo literário, o estilo pedagógico e a estilometria dos textos de Platão. É claro e evidente que, divididos para fins de análise mais acurada, esses aspectos em um texto filosófico podem se confundir e acabam tendo entre si uma fronteira porosa - e ainda assim, no entanto, distinguilos ajuda a tornar mais claros os termos de um debate já suficientemente complexo e acirrado.

\subsubsection{O estilo literário}

Uma das observações feitas pelos partidários da espuriedade é a de que "a linguagem e o estilo da carta foram considerados não característicos de Platão"30. Quando se fala vagamente em “estilo literário", em geral aquilo a que se refere é um difuso "sabor" do texto, a maneira como ele soa, e certos usos recorrentes que os autores fazem de recursos da língua. É assim que se fala, por exemplo, do estilo de Marcel Proust, com suas frases longas e seus arabescos descritivos, ou do estilo seco, direto e pouco adjetivado de Graciliano Ramos, ou do "estilo impressionista" de Tchekhov, ou do estilo crítpico e hermético de Heidegger, ou do estilo contundente de Nietzsche. Com referência a esse estilo geral, diz-se às vezes que a Carta VII não "soa" como um texto escrito por Platão. A referência toma como parâmetro não as demais cartas (o que é compreensível, já que também elas, aliás mais frequentemente do que a VII, têm a autoria contestada), mas sim os diálogos, e enxerga entre eles um contraste que, creem alguns, seria significativo ${ }^{31}$.

A primeira coisa a observar é que essas considerações são de caráter um tanto vago, e podem comportar o uso de impressões algo subjetivas ou idiossincráticas diante do texto de Platão - o que dá ocasião a curiosas divergências. Luc Brisson, por exemplo, diz que ${ }^{32}$ “o estilo das cartas não se afasta espetacularmente do estilo de Leis, que, à época, Platão estaria em vias de escrever". R. G. Bury, que, como Brisson, é partidário da autenticidade da Carta VII,

\footnotetext{
${ }^{30}$ IRWIN, op. cit., p. 15.

${ }^{31}$ Um defensor particularmente importante da tese foi Goeorg Misch, no capítulo dedicado à Carta VII do seu History of autobiography in Antiquity.

${ }^{32}$ Op. cit., p. 139.
} 
reconhece no entanto alguns elementos que causam estranheza no estilo da epístola: o relato e a estruturação do texto seriam "um tanto confusos" 33 , e o autor ali se expressaria "de maneira algo apaixonada" 34 - querendo com isso dizer que é um texto emocionalmente investido, talvez apressado, distante do cuidado característico que o escritor Platão costumava cultivar.

Uma resposta possível a essas objeções é simples e bastante direta: é evidente que o estilo literário de uma epístola há de ser bastante distinto do estilo empregado em uma obra como um diálogo. Ainda que se considere, como aqui é o caso, que também a VII é uma obra pensada para ampla circulação, há de se convir que se trata de um outro tipo de circulação, com outros propósitos e outra amplitude. É evidente para qualquer estudioso que os diálogos são peças ao mesmo tempo literárias e filosóficas, e que todos os elementos de que se constituem têm profundo significado - um significado claramente intencionado e cuidadosamente disposto. O preciosismo com que Platão arranjava esses elementos, e mesmo o cuidado linguístico e literário na composição do texto, não seria o mesmo quando da composição de uma carta - o que certamente dá conta da pretensa desorganização, da "confusão" e da "paixão" enxergadas por Bury na composição da VII. Especialmente aqui é preciso levar em conta que muitas passagens dos diálogos são obras verdadeiramente poéticas, com a clara intenção de causar um impacto estético nos leitores, inclusive com recurso a imagens, mitos e símbolos, e também a figuras de linguagem que buscam o efeito da beleza no próprio uso vernacular - aliterações, metáforas, contrastes, citações ou alusões feitos às epopeias, à poesia lírica e às tragédias. Os exemplos são tantos e tão evidentes que seria desnecessário aqui recorrer a uma análise ilustrativa ou exaustiva dos casos. Mencione-se apenas que a atenção que Platão dava à sonoridade das palavras, e ao seu efeito em termos de impacto poético, ficam evidentes não só pelo próprio texto dos diálogos, mas por discussões explícitas a esse respeito, como a que se dá no Crátilo sobre as etimologias, e sobre como a constituição sonora incide sobre o significado das

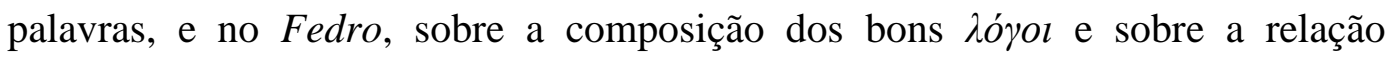
necessária entre forma e conteúdo (257c-279c). É evidente que aquilo que Sócrates diz sobre o artesanato dos bons discursos, pensados como obras que visam à beleza,

\footnotetext{
${ }^{33}$ Op. cit., p. 471.

${ }^{34}$ Op. cit., p. 472.
} 
à persuasão e à ensinaça, também se aplicaria a uma obra como os seus diálogos (264c, trad. de Carlos Alberto Nunes):

todo discurso deve ser construído como um organismo vivo, com um corpo que lhe seja próprio, de forma que não se apresente sem cabeça nem pés, porém com uma parte mediana e extremidades bem relacionadas entre si e com o todo.

A distância que separa uma obra literário-filosófica de caráter poético de uma carta como a VII também dá conta da presença dos traços "pouco platônicos" no texto apontados por Burnyeat no apêndice de seu livro sobre o assunto ${ }^{35}$ : a repetição seguida de certas palavras, quando seria possível recorrer a sinônimos ou substitutivos mais elegantes; a recorrência, ao longo do texto, de certos termos reiterados (Burnyeat manifesta especial incômodo pelas 16 vezes em que o léxico $\theta \alpha v \mu \alpha \tau o ́ s$, adjetivo ou advérbio, aparece ${ }^{36}$ ); o uso excessivo de palavras com o prefixo $\delta \iota^{-}$, o que denotaria talvez certa pobreza vocabular.

Ainda no que diz respeito ao estilo literário, uma última consideração se faz necessária. Na franca contramão daqueles que veem na Carta VII um texto apressado e indigno do escritor e poeta que foi Platão, o mesmo Burnyeat defende a espuriedade do documento tomando para isso argumentos opostos: o texto seria uma composição cuidadosa demais do ponto de vista dramático, o que a tornaria suspeita de ser não uma carta exortativa com fins políticos imediatos, mas uma construção fictícia que antes se assemelharia a uma tragédia em prosa. A partir disso, ele vê como defensável a tese de que o texto não foi escrito por um filósofo, e sim por um escritor de ofício. A tese é exaustivamente exposta e defendida no ensaio The second prose tragedy: a literary analysis of the pseudo-Platonic Epistle VII, encartado na obra The pseudo-Platonic Seventh Letter, em co-autoria com Michael Frede. Passemos a algumas considerações sobre esse ensaio, que merece atenção pela peculiaridade dos argumentos apresentados.

\footnotetext{
35 Op. cit., p. 193.

${ }^{36}$ Op. cit., p. 138 , nota 7.
} 
Burnyeat inicia a sua análise afirmando que o próprio Platão já havia cogitado, em Leis 817 b, a ideia da composição de tragédias em forma prosaica - o que é estranhíssimo, visto que, consultando-se exatamente essa passagem, vê-se que o Ateniense fala em transformar a própria vida da cidade em uma bela obra dramática, e rigorosamente nada diz sobre a composição de tragédias em prosa ${ }^{37}$. Então argumenta o comentador: algum escritor posterior, talvez aluno de alguma escola literária como as que se multiplicaram a partir do período helenístico, teria decidido tomar a ideia e aplicá-la à própria vida de Platão - sem explicar por que razão seria o caso de fazê-lo sob a forma epistolar, nem tampouco com tal grau de minúcia historiográfica a ponto de enganar todos os historiadores da época e dos decênios seguintes. A tese também certamente não dá conta dos argumentos estilométricos, mas desses trataremos logo mais adiante.

Burnyeat dá as razões para a sua hipótese: o autor da carta conduz a história com notável maestria narrativa, gerando suspense e apreensão no desenrolar dos acontecimentos: ele omite certas informações, deixa o leitor em suspenso sobre temas insinuados e só depois revelados, interrompe a narrativa em alguns momentos para reter a atenção etc. Além disso, o escritor teria organizado o desenvolvimento das ações segundo alguns dos os cânones da composição tragediográfica apresentados por Aristóteles na Poética, como a conexão necessária entre os acontecimentos que distingue a poesia da mera historiografia. Ele encontra na narrativa da carta um prólogo (323d-326b), três atos (326b-327d, 327d-330b e 337e-341e/344d-350b), que divide em cenas, interrompidos por interlúdios e digressões, e, por fim, um epílogo (350b-352a). É de se notar aqui que esse modo de analisar o tex to internamente não é seguido por nenhum outro estudioso da carta, os quais sempre encontraram certo acordo em ver nela partes bem clara e intencionadamente distintas: as duas primeiras visitas a Siracusa, os conselhos aos amigos e parentes de Díon, a terceira visita e as considerações finais. Difícil não lembrar aqui do "mau açougueiro" mencionado em Fedro 265e, já que a divisão em atos e cenas proposta por Burnyeat não só aplica a um texto antigo um tipo de divisão que é própria dos dramas modernos, como também força muitos aspectos

\footnotetext{
${ }^{37}$ Eis a passagem, na tradução de Carlos Alberto Nunes: "nós também compusemos nossa tragédia, a melhor e mais bela que nos foi possível levar a cabo. Nossa constituição inteirinha não passa de imitação do que a vida tem de mais belo e excelente, imitação que nós, pelo menos, consideramoa verdadeira tragédia. Sois criadores, como também o somos, no mesmo gênero de poesia; concorrentes e rivais no mais belo drama que somente a verdadeira lei é capaz de realizar."
} 
do texto (não se explica, por exemplo, por que o "terceiro ato" estaria dividido em duas partes, e por que seria tão mais longo que os dois anteriores do "drama”).

É realmente curioso que os argumentos contrários à autenticidade da carta variem dos que afirmam ser ela textualmente pobre demais até aqueles que alegam ser ela elaborada demais. Aqui, para os nossos fins, isso importa pouco: há outras maneiras de mostrar a insuficiência dessas alegações. Fato é que não foi essa a única tentativa de apresentar o texto das cartas como uma elaboração literária, ou uma espécie de romance para apreciação de uma história estimulante. Friedländer dá notícia de que o mesmo foi tentado por Franz Dornseiff, na obra Echtheitsfragen antik-griechischer Literatur ${ }^{38}$. Seja como for, a tese é claramente insuficiente na medida em que não explica por que não poderia ser o próprio Platão o autor desse "drama”, com os mesmos propósitos de impressionar eficazmente (digamos, esteticamente) os seus leitores, e assim convencê-los melhor. Essa aliás é a ideia que Bury defende, com a evidente vantagem de atribuir à iniciativa uma sólida motivação ${ }^{39}$ :

\begin{abstract}
Então, o que Platão está fazendo nesta carta é engajarse em uma ficção literária que lhe permite publicar, sob a forma de um epistolário, aquilo que é ao mesmo tempo uma história, uma apologia e um manifesto. Para qual público, então, ela se dirige (...)? Deve haver pouca dúvida quanto à resposta: Platão está principalmente preocupado em influenciar seus compatriotas: as fofocas ignorantes, os boatos maliciosos, as danosas acusações que circulavam em Atenas eram o que mais o aborrecia, o que ele mais ansiava refutar.
\end{abstract}

O mesmo Bury então aponta as semelhanças entre essa empreitada e aquela levada a cabo por Isócrates em seu Antidosis. As comparações de estilo literário não devem ser feitas em relação às demais cartas do corpus platônico e nem tampouco em relação aos diálogos, pelas razões já aludidas - mas sim em relação a esse gênero literário já estabelecido e praticado, o da apologia pro vita sua, em que um

${ }^{38}$ FRIEDLÄNDER, op. cit., p. 236.

${ }^{39}$ BURY, op. cit., p. 474. 
personagem conhecido justifica sua ação na vida pública. O gênero foi não apenas usado por Isócrates, mas temos também dele um exemplo na própria Apologia de Sócrates, frequentemente considerado modelo tanto da VII quanto do Antidosis. Se for feita essa comparação, diz Bury ${ }^{40}$, serão observados os "muitos pontos de contato" entre os textos das cartas abertas de Platão e de Isócrates - e alguns desses pontos de semelhança, aliás, são reconhecidos pelo próprio Burnyeat ${ }^{41}$.

\subsection{2. $O$ estilo pedagógico}

Se, em relação ao estilo literário, houve quem dissesse que o texto da Carta VII não "soa" como Platão, houve também quem, como uma questão à parte, dissesse que o autor da epístola não expõe ideias da mesma maneira e nem com a mesma competência com que o filósofo ensina em suas demais obras. De fato, no texto dos diálogos, as ideias filosóficas costumam ser escrutinadamente apresentadas, e diversos ângulos de uma mesma questão são tomados, sempre com o propósito de esgotá-las. O Platão que escreve diálogos procura se antecipar a possíveis objeções, retomar as discussões sob outros aspectos, descer a minúcias para tirar dúvidas de seus interlocutores, recorrer a exemplos exaustivos e aos mais diversos recursos pedagógicos que estivessem à mão - mesmo, como no caso do diálogo Mênon, chamar à "cena" um escravo para demonstrar aquilo que todos os leitores já sabem por experiência direta (ou seja, que as pessoas são capazes de aprender algo).

Todo esse cuidado e esse escrúpulo estariam ausentes do texto da carta - e nisso estão de acordo tanto os partidários da autenticidade quando os da espuriedade. Posições políticas não são suficientemente embasadas filosoficamente, argumentos são apresentados de maneira lacônica, conselhos são dados sem maiores explicações e, especialmente no trecho celebremente conhecido como "excurso filosófico" (342a-344d), as ideias seriam apresentadas de maneira falha e tosca, envolvendo mesmo alguma confusão terminológica. Não se trata ainda, note-se, de uma objeção quanto ao conteúdo desse excurso, e nem tampouco

\footnotetext{
${ }^{40}$ Op. cit., p. 474.

${ }^{41}$ Op. cit., p. 148.
} 
da discussão sobre a possibilidade de compatibilizá-lo com aquilo que conhecemos sobre a filosofia de Platão pelos diálogos (trataremos de tal questão em uma seção à parte). Trata-se, isso sim, de afirmar que não seria dessa maneira que Platão apresentaria ideias tão caras a respeito de filosofia política, organização da pólis, a necessidade de um governo encabeçado por filósofos, da dimensão ética do aprendizado filosófico - e, em especial, a respeito de ontologia, teoria do conhecimento e filosofia da linguagem (que são os temas do excurso).

Para ilustrar essa objeção, citemos alguns exemplos. Bury faz menção à

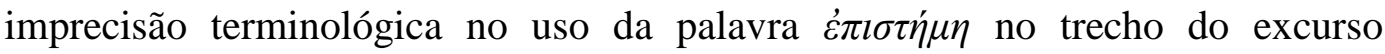
filosófico, e observa, com razão, que ele parece ser empregado ambiguamente em alguns sentidos diferentes - às vezes como "apreensão intelectiva", às vezes como "conhecimento obtido pelo pensamento" ${ }^{42}$. A observação não é desprezível, dada a importância do termo em qualquer contexto filosófico, mas em especial no pensamento de Platão. Terence $\operatorname{Irwin}^{43}$ chama atenção para o fato de que, embora tanto na República quanto na carta seja defendida a tese do governo por parte de filósofos, os argumentos usados em cada caso são diferentes, o que mostraria uma preocupação distinta por parte de quem as escreveu. Faz referência também à pouca ênfase dada à figura de Sócrates - condutor central das investigações dialéticas nos diálogos, além de modelo de vida filosófica e de virtude. Irwin esperaria de Platão, como conselheiro, que apresentasse Sócrates como modelo de virtude a ser imitado, tal como o fez nos diálogos ${ }^{44}$. O mesmo comentador estranha ${ }^{45}$, além disso, o desprezo pela forma escrita, tal como exposto na VII (e diferentemente do que é dito no Fedro), porque daria a entender que os diálogos não versam "sobre assuntos


filosófico e sobre os cinco níveis de realidade, à parte as muitas críticas a respeito do conteúdo propriamente dito, ele observa ainda que o autor da carta expressa-se de maneira obscura, e que é "um tanto difícil saber o que ele tem em mente" ${ }^{\text {. }}$.

\footnotetext{
${ }^{42}$ Op. cit., p. 473.

${ }^{43}$ Op. cit., p. 24.

${ }^{44}$ Op. cit., pp. 22-23.

${ }^{45}$ Op. cit., p. 28.

${ }^{46}$ Tradução alternativa, adotada por José Trindade dos Santos e Juvino Maia Jr.: "assuntos de que me ocupo".

${ }^{47}$ Op. cit., p. 35.
} 
As críticas mais contundentes quanto ao estilo pedagógico, no entanto, nos vêm novamente de M. Frede e de M. Burnyeat. Frede se concentra em grande parte na fragilidade que enxerga na posição que considera mal definida, tal como expressa na carta, entre as ideias políticas apresentadas na República e aquelas apresentadas em Leis. Diz que as ideias estão mal expostas e que não embasam suficientemente a sua tese de que os filósofos devem governar ${ }^{48}$; observa que o autor da carta não expôs ao longo do texto quais características ou traços de caráter deve ter o filósofo apto a governar ${ }^{49}$; que não exauriu as alternativas a essa possibilidade, como por exemplo o de um arranjo legal tal como proposto em Leis $^{50}$; que ele não expõe claramente quais características viu nas almas de Dionísio II e de Díon a ponto de enxergar neles potenciais reis-filósofos ${ }^{51}$; que foi lacônico ao considerar as possibilidades políticas concretas de Siracusa, à luz de Leis ${ }^{52}$; e, por fim, que o autor afirma de maneira filosoficamente irresponsável que, numa pólis governada por filósofos, os próprios cidadãos serão imensamente felizes ( $\dot{\mu} \mu \dot{\eta}_{\chi} \chi \alpha \nu v$

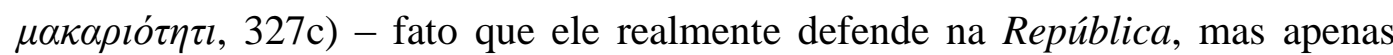
depois de longa e cautelosa exposição ${ }^{53}$. Conforme se vê, essas críticas específicas de Frede não se dirigem exatamente ao conteúdo das ideias apresentadas na carta, que ele próprio admite serem muito próximas das da República ${ }^{54}$, mas sim à forma como o autor as apresentou: elas soam lacunares, mal explicadas, não suficientemente analisadas aos seus destinatários.

As críticas de Burnyeat ao estilo pedagógico do autor da carta se reportam a outras questões - antes de mais nada, a suas ideias ontológicas e epistemológicas. Diz por exemplo que, no excurso filosófico, o autor é "pouco platônico" 55 (unPlatonic) no mau manejo dos argumentos sobre as limitações da linguagem humana, e que diz ser capaz de prover mais provas do que alega, mas não o faz; afirma que ele baseia suas ideias em argumentos não apenas inválidos, mas que mal se fazem entender ${ }^{56}$; que uma comparação com outros diálogos nos mostra que

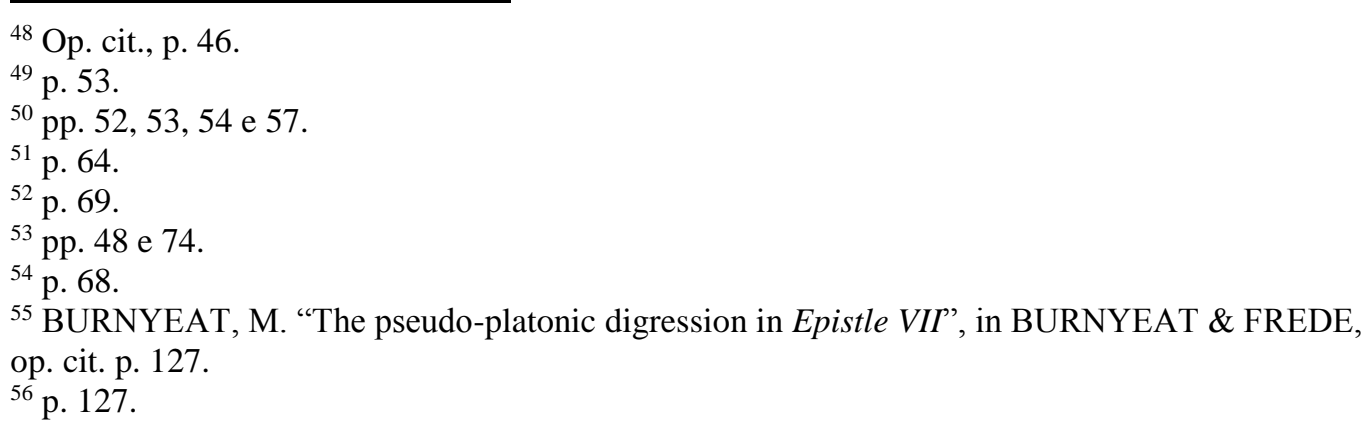


Platão jamais incorreria no erro de apresentar erros crassos de inferência ${ }^{57}$; que a

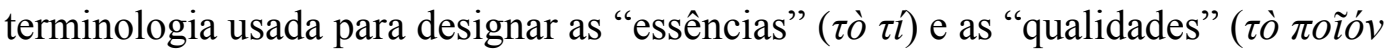
$\tau \iota)$, que não se encontra nos diálogos, ou denota "incompetência filosófica" ou é prova de espuriedade. Além disso, Burnyeat também chama de "raquítica" a sua defesa do regime do rei-filósofo, sem o embasamento suficiente para prová-la ${ }^{58}$. Como Terence Irwin, diz que seria de se esperar de Platão que Sócrates fosse mais enfaticamente proposto como um modelo de virtude e de atuação na vida pública ${ }^{59}$. Observa ainda o estilo "altamente retórico" como o autor condena os perigos de uma vida dissipada nos prazeres ${ }^{60}$. E, por fim, afirma que os céticos em relação à autoria da carta têm toda razão em enxergar, na maneira como conceitos e argumentos são manejados no texto, um escritor pouco versado nesses assuntos: "confuso", "obscuro" e "ilógico" nas suas exposições ${ }^{61}$. Seu malogro pedagógico denuncia que ele está tentando apenas "soar como um filósofo", e não efetivamente filosofar ${ }^{62}$.

Algumas explicações bastante simples e diretas podem ser oferecida para dar conta dessas objeções. Em primeiro lugar, o formato do escrito e o gênero literário: trata-se de uma carta, e não de um tratado filosófico. Não é razoável esperar que uma epístola como essa, escrita nas circunstâncias que ela própria descreve, expusesse esmiuçadamente e encadeasse uma série de teses e argumentos, como se fora uma longa investigação dialética. Inventário de opiniões, antecipação de objeções, exposições exaustivas, preciosismo terminológico - tudo isso poderia ser facilmente considerado excessivo nessas circunstâncias. Cobrar detalhamento e aprofundamento filosófico da VII seria mais ou menos como queixar-se de que um filósofo que publica uma carta em um jornal não foi profundo como nas suas obras.

Em segundo lugar, é preciso levar também em conta os interlocutores a quem a epístola se dirige. Quer consideremos que o autor a escreve de fato para os “parentes e companheiros de Díon”, quer suponhamos que ele tinha em mente a população grega ou ateniense em geral, seu público-alvo não era o de pessoas dos meios e ambientes filosóficos, necessariamente versadas no pensamento dialético -

\footnotetext{
${ }^{57}$ p. 128.

${ }_{58}$ p. 141.

${ }^{59}$ p. 145.

${ }^{60}$ p. 153.

61 p. 167.

62 p. 168.
} 
na verdade, seria difícil supor que o fossem. Além de deslocadas, considerações que entrassem em minúcias de discussão talvez constituíssem antes um ruído do que um esclarecimento.

Por fim, é preciso ainda levar em conta quais eram os propósitos declarados da carta: o de precipitar uma ação política. Se o texto tem uma intenção ulterior, conforme supõem vários intérpretes, é o de apresentar uma apologia pro vita sua, ou seja, o de justificar o envolvimento de Platão na política siciliana, e o de defender seu nome de uma série de calúnias que circulavam a seu respeito. Qualquer que seja o caso, preleções filosóficas e exposições conceituais contribuiriam muito pouco para esses fins - e talvez tenham sido apresentados apenas na medida em que contribuíssem. Se levarmos a sério a intenção declarada do texto, seu autor se reporta a um grupo específico de atores políticos, quer convencê-los a uma conversão de vida, e, caso se comprometessem a fazê-lo, pôr-se à disposição para ajudá-los. A modalidade discursiva mais apropriada para persuadir e precipitar ações é evidentemente a retórica, e não a dialético-investigativa. $\mathrm{O}$ que surpreende no texto da VII é justamente o contrário: que, numa missiva desse teor, haja ainda assim a presença de tantas exposições filosóficas.

É curioso que o próprio Frede reconheça que era esse o caráter do público a que a carta se dirige, e ainda assim insista nas críticas que apresentou. Diz ele ${ }^{63}$ (com grifo nosso):

Portanto a carta, embora formalmente uma carta ou um aconselhamento, na verdade em substância torna-se uma apologia. E tal apologia, conforme frequentemente observado, tem de alguma maneira o caráter de uma carta aberta. Em todo caso, ela certamente não é dirigida a filósofos, mas a um público mais amplo.

\subsection{Estilometria}

Em questões imensamente controversas a respeito da obra de Platão - como

\footnotetext{
${ }^{63}$ p. 41.
} 
a ordenação dos diálogos ou a autenticidade de alguns escritos -, há muito que os filólogos e estudiosos desejam encontrar algum critério, digamos, "objetivo" de orientação. Se houvesse algum elemento mensurável que nos fornecesse, além de toda dúvida razoável, alguma espécie de “impressão digital” deixada inconscientemente pelas obras, e que atestasse não apenas por quem ela foi "tocada", mas em que momento isso aconteceu, esse seria sem dúvida um critério imensamente valioso. Exatamente com esse fim foi desenvolvido o tipo de estudos chamado "estilometria", ou seja, uma espécie de minuciosa análise estatística de dados linguísticos a respeito de um texto. Os dados mensurados por esse método são de vários tipos, e alguns são traços de estilo que podem ser ditos "conscientes" - como, por exemplo, evitar a ocorrência de hiatos (no sentido em que se usa esse termo na língua grega, ou seja: a ocorrência de um encontro vocálico entre duas palavras, ou da junção entre uma palavra que termine em vogal e de uma outra que também com vogal se inicie). Outros talvez fossem usos linguísticos que talvez pudéssemos chamar de "inconscientes" - como o tamanho médio das frases ou o ritmo prosódico (combinações de sílabas breves e longas no final das frases). A fronteira entre os traços conscientes e inconscientes não é absoluta, e em alguns casos não é nem mesmo clara, pois há critérios como padrões de subordinação das orações, a recorrência de certos termos, em especial partículas, e assim por diante. Mas isso pouco importa: fato é que nos últimos 150 anos a adoção da análise estilométrica dos textos trouxe inegável contribuição para o estudo dos escritos de Platão - encerrou discussões, estabeleceu novos patamares de compreensão, e logrou alcançar consensos diante de uma obra que parece fadada a ser objeto de discussões infindáveis.

A primeira conquista do método estilométrico foi justamente a de trazer alguma luz sobre o problema da ordenação cronológica dos diálogos - que, conforme veremos, é de especial importância na análise da Carta VII. Em 1862, Lewis Cambpell publicou a obra The sophists and the other companions of Socrates $^{64}$, em que apresenta logo na introdução o seguinte arrazoado: se sabemos por fontes externas (Aristóteles e Olimpiodoro) que Leis foi uma das últimas obras escritas por Platão, que aliás a teria deixado inacabada, as características de estilo dessa obra poderiam ser usadas como parâmetro para encontrarmos outras obras

\footnotetext{
${ }^{64}$ Oxford: Oxford University Press, 1967.
} 
que também tivessem sido escritas nos últimos anos da sua vida. Usou para isso como critério não só a recorrência de certas palavras e partículas por página, mas também ritmo, tamanho e ordenação das frases. Chegou assim à conclusão, ainda modesta mas muito significativa, de que as obras Fedro, Sofista, Político, Timeu e Crítias haviam sido redigidas mais ou menos na mesma época.

A partir dessa ideia inicial, vários outros filólogos resolveram se dedicar a análises estilométricas diversas, que tomavam critérios diferentes de mensuração para alcançar novas descobertas, e chegavam a conclusões bem mais ambiciosas agrupamento de todos os diálogos por fases, estabelecimento de uma ordenação geral obra a obra, e mesmo, o que também nos interessa aqui, a autenticidade ou espuriedade de alguns escritos. A partir do impulso inicial dado por Campbell, a história dos estudos de estilometria se complexifica formidavelmente, e não é este o lugar para exauri-la ${ }^{65}$. Basta apenas registrar que, até o advento de recursos tecnológicos para esse fim, por volta da década de 60 , poucos avanços haviam sido feitos, e as análises estilométricas dos estudiosos não tomavam a carta como objeto de estudo.

Conforme seria de se esperar, o desenvolvimento de recursos tecnológicos abriu muitas possibilidades e deu novo fôlego às análises estilométricas, já que tornaram possível computar e processar uma quantidade assombrosa de dados, além de entrecruzá-los e compará-los com grande facilidade. O uso de computadores também trouxe a possibilidade de averiguar alguns critérios antes vislumbrados por estudiosos, mas que não tinham como ser contabilizados - W. Kaluscha, por exemplo, desejava mensurar todo o ritmo da prosa de Platão, mas, por falta de recursos técnicos, ateve-se a uma análise que se restringia ao final das frases ${ }^{66}$.

Em 1969, dois estudos foram publicados e trouxeram novidades a esse respeito. Um deles incorria em crassos erros metodológicos, e o exporemos sucintamente apenas para fins de completude desta pesquisa. M. Levison, A. Q. Morton e A. D. Winspear publicaram, na revista $\operatorname{Mind}^{67}$, um artigo que tentava provar a espuriedade da Carta VII com base em uma comparação estilométrica com

\footnotetext{
${ }^{65}$ A esse respeito, v. BRANDWOOD, L. "Estilometria e Cronologia" in KRAUT, R. (org.). Platão. SP: Ideias \& Letras, 2013.

${ }^{66}$ BRANDWOOD, L. Op. cit., p. 129.

${ }^{67}$ The Seventh Letter of Plato. Mind. Mind, Vol. 77, No. 307. pp. 309-325, 1968.
} 
a Apologia de Sócrates. Usaram para isso os seguintes critérios: a distribuição da conjunção $\kappa \alpha i$; a distribuição da partícula $\delta \varepsilon ́$ como segunda ou terceira palavra das frases; o tamanho das frases. Naturalmente, encontraram discrepâncias. A primeira objeção é bastante óbvia e logo foi apontada pelos estudiosos: qualquer dos escritos tardios de Platão apontaria as mesmíssimas discrepâncias se comparados com a Apologia. Uma análise do tipo deveria antepor o texto da epístola a um diálogo como Leis, e nunca com uma das primeiras obras. Os próprios autores do artigo reconhecem que tais discrepâncias também ocorrem entre as obras da juventude e tardias de Isócrates, e reconhecem que as variações de estilo são comuns ao longo da vida de um autor, mas não levam em consideração o fato de que 40 anos presumivelmente separariam a redação da Apologia da redação da VII. Na verdade, mais do que isso, seria preciso ponderar que a estilometria foi inventada exatamente para fazer esse tipo de distinção, entre obras tardias e juvenis. Ainda sobre as discrepâncias em Isócrates, os autores as atribuem ao fato de que as obras analisadas pertencem a gêneros literários diferentes - e desconsideram o fato de que um diálogo e uma carta também são gêneros inteiramente diferentes, conforme já tivemos ocasião de ponderar. Uma resposta exaustiva ao artigo de Levison, Morton e Winspear foi escrita por Philip Deane, na mesma revista Mind, no ano de $1971^{68}$, com o significativo título Stylometrics do not exclude the seventh letter.

Também em 1969, L. Brandwood ${ }^{69}$ fez uma primeira tentativa criteriosa de comparar o texto da carta com o dos diálogos tardios, e chegou à conclusão de que estão presentes nela todas as características usadas como critério para delimitar as últimas obras, como o esforço deliberado por evitar os hiatos e um tipo próprio de ritmo de prosa, medido quantitativamente.

Finalmente, em 1989 G. R. Ledger trouxe para o debate a última grande contribuição em seu livro Re-counting Plato. Na obra, Ledger analisou todos os textos atribuídos a Platão: os considerados autênticos, os apócrifos, os suspeitos e as cartas, tanto com o propósito de verificar a autenticidade quanto o de estabelecer uma cronologia presumível. Em grande medida, seus estudos confirmaram as conclusões anteriormente obtidas pela estilometria, especialmente no que diz

\footnotetext{
${ }^{68}$ vol 82, n. 325, pp. 113-117.

${ }^{69}$ BRANDWOOD, L. "Plato's Seventh Letter", in Revue de l'Organisation internationale pour l'Étude des Langues anciennes par Ordinateur. 1969, n. 4, pp. 1-25.
} 
respeito ao agrupamento dos diálogos em três grandes fases. Um dado novo, no entanto, foi acrescentado: suas análises encontraram todos os indícios de autenticidade em algumas obras frequentemente contestadas, como o Primeiro Alcibíades, o Hípias Maior e, o que nos interessa especialmente aqui, a Carta VII. O cruzamento de vários dados chegou ainda à conclusão de que as epístolas III, VII e VIII teriam sido escritas em época próxima à dos diálogos Sofista, Político, Leis, Timeu e Crítias

Em um debate tão repleto de suposições e critérios fugidios, e frequentemente impulsionada por paixões que beiram o irracional, o dado da moderna estilometria talvez seja o mais contundente, e o que apresenta a objeção mais desafiadora aos partidários da tese da espuriedade. Não estamos com isso afirmando que a estilometria seja um critério último ou insuperável para o estabelecimento da autenticidade - mesmo porque, quando descemos às minúcias das análises, é fácil perceber que pode haver arbitrariedades na escolha daquilo que é considerado um traço relevante de estilo, e é sempre possível tentar novos recortes e interpretação dos $\operatorname{dados}^{70}$. Mas é também evidente que uma conclusão desse impacto mereceria no mínimo uma resposta sólida e bem embasada. Nem sempre tem sido o caso: M. Frede e M. Burnyeat, por exemplo, não fazem menção a ele e nem tampouco incluem a obra de Ledger em sua bibliografia sobre a epístola. Terence Irwin a menciona na introdução que redigiu para a Carta VII, mas tenta contornar a questão com um argumento que já foi bastante usado por partidários da espuriedade, e que passaremos a analisar a seguir.

Irwin e outros intérpretes levantaram a seguinte hipótese: a de que talvez a carta tenha sido escrita por alguém muito próximo de Platão, um aluno ou membro da academia, capaz de emular o seu estilo mesmo nos seus traços inconscientes, como muitos dos que são analisados pelas estatísticas estilométricas. Existe aliás esse quase consenso entre os partidários da espuriedade: a carta foi forjada por

\footnotetext{
${ }^{70}$ Um exemplo para ilustrar a questão: a ocorrência natural e espontânea de hiatos na língua grega é de mais de 40 por página Stephanus; nos últimos diálogos, Platão passa a evitá-los, e a frequência cai para cerca de quatro por página. Nota-se a intenção deliberada de evitá-los pelo uso de sinônimos, inversões etc. A baixa frequência de hiatos foi tomada como critério para agrupamento cronológico das obras, delimitando uma característica do seu estilo tardio. Houve no entanto estudiosos que redarguissem: sendo um traço intencional de estilo, Platão pode tê-lo adotado e abandonado alternadamente ao longo da vida. Por isso tem-se considerado que as análises estilométricas mais confiáveis são aquelas que cruzam vários traços estilísticos das obras, e encontram nesse cruzamento as interseções mais claras.
} 
algum membro da academia de primeira geração ${ }^{71}$, talvez preocupado em defender a reputação do mestre, abalada por calúnias diversas sobre o que o motivou em sua empreitada política em Siracusa ${ }^{72}$. Entre os defensores da tese do "forjador próximo", é preciso ainda mencionar que um nome costuma ser ventilado como principal suspeito para essa iniciativa: Espeusipo, sobrinho de Platão e seu sucessor à frente da Academia. A autoria daria conta de alguns fatores: por um lado, o conhecimento em detalhes dos fatos narrados, tanto sobre a política em Siracusa quanto sobre a própria vida de Platão; a intimidade com as obras e com o estilo de Platão; o desejo de defender a memória do filósofo caluniado; e, por fim, as discrepâncias filosóficas que alguns supõem existir entre o excurso filosófico e os diálogos. Espeusipo é apontado como provável autor por Terence $\operatorname{Irwin}^{73}$, e também pelo trio Levison, Morton e Winspear, autores do artigo acima mencionado, entre outros.

De fato, por todos os fatores analisados, se for necessário levantar uma subhipótese dentro da hipótese da espuriedade, seria bem razoável supor a autoria de algum membro da primeira Academia, mestre do estilo e imitador exíguo. Mas é evidente que tal possibilidade só precisa ser levantada se houver uma sólida razão para ela - afinal, por que não cogitar a mesma hipótese a respeito de qualquer outra obra de Platão, e afirmar que, apesar de trazer seu nome, suas ideias e sua “impressão digital” estilométrica, foi escrita por um discípulo e não por ele? É bem mais simples e "ockhaminano" supor que o estilo compatível, a familiaridade com os dados biográficos de Platão e acurácia na descrição da situação política de Siracusa se explicam por ter sido o próprio Platão o autor do texto.

Observe-se ainda um ponto importante para fins de ênfase. Quando na dúvida a respeito da autenticidade de um texto, intérpretes e comentadores costumam submetê-lo a vários exames - no caso da carta, como temos visto, um exame estilístico, um exame historiográfico etc. Passar por muitos desses "testes" normalmente constitui apenas uma "não refutação" para a sua autenticidade. É o

\footnotetext{
${ }^{71}$ Em What Plato said, pp. 40-41, Shorey diz que, pelo estilo literário, a carta não pode ter sido escrita mais do que uma ou duas gerações depois de Platão.

72 "Quase consenso" porque há pelo menos uma voz discordante: Miles Burnyeat. Conforme já dito, ele acredita na hipótese de um hábil escritor de ofício que tenha vivido algumas gerações depois, e que, portanto, a carta não seria confiável nem mesmo como testemunho a respeito da primeira Academia ou dos fatos narrados.

${ }^{73}$ Op. cit., pp. 42 e ss.
} 
caso, por exemplo, da acurácia histórica dos eventos narrados: se houvesse algum erro comprometedor, seria um forte argumento em contrário; como não há, não houve refutação, e a investigação segue mais ou menos onde estava. Mas passar pelo "teste estilométrico" é algo de outra ordem: provada a sua compatibilidade com o estilo do último Platão, isso não constitui uma mera "não refutação" da autenticidade da carta, mas sim um decisivo indício em favor da autenticidade. As análises estilométricas de Legder e Brandwood são exatamente isso, e na verdade o último dado relevante a incidir sobre essa discussão. A partir disso, quem passa a dever sólidos argumentos explicativos são os que a negam.

\subsection{Os argumentos filosóficos}

É em torno das questões filosóficas que se concentram os principais pontos de controvérsia em torno da autoria da Carta VII. Embora existam outros pontos de dissenso, conforme discutido acima, as discussões se tornam mais agudas quando o debate se encontra em torno do conteúdo filosófico que a carta parece expor.

Existe na questão um agravante, que de certa maneira explica o caráter apaixonado do debate. É sobejamente conhecido o problema do "anonimato platônico", ou seja, a dificuldade de extrair de falas de personagens de um diálogo uma tese que se possa atribuir a seu autor. Vamos nos reportar a essa questão em um capítulo ulterior desta mesma pesquisa - mas, desde já, é preciso aludir a ela de passagem. Um dos traços que torna a Carta VII tão especial é o fato de ela trazer um discurso filosófico de Platão na primeira pessoa, que seja possível atribuir diretamente a ele, sem nenhum ruído ou interferência de transmissão. Dependendo da maneira como as tratemos, as considerações filosóficas da VII têm, portanto, o poder de embasar ou de refutar peremptoriamente correntes interpretativas inteiras. É compreensível que, em alguns casos, intérpretes e comentadores a ataquem ou a defendam como quem protege suas hipóteses mais caras sobre a interpretação de Platão. 
Conforme já dito anteriormente, durante a metade do século XX a questão da autenticidade da epístola foi tida como encerrada, especialmente pela autoridade da posição adotada por Wilamowitz. Hackforth e Gerog Misch constituíram nisso a mencionável exceção. Quem, em grande medida, reabriu os arquivos e ressuscitou a polêmica foi Ludwig Edelstein, em sua obra Plato's Seventh Letter. Logo na introdução da obra, o autor diz que critérios como o historiográfico ou o estilístico são todos compatíveis com a tese da autenticidade - os fatos mencionados são acurados, e o estilo é realmente platônico. São bons indícios, diz ele, mas não definitivos - um bom forjador poderia estudar os fatos e imitar o estilo. O grande critério em disputa, afirma ele, é o conteúdo filosófico da carta - e é justamente aî que ele encontra provas suficientes para afirmar a sua espuriedade. Desde então, os críticos da autenticidade, ainda que mencionem outras razões, assentam seus argumentos em uma variação da afirmação "Platão jamais teria dito isso". É especialmente por conta do conteúdo filosófico que a rejeitam, total ou parcialmente, não apenas Edelstein, mas também T. Irwin, M. Frede, M. Burnyeat, Constantin Ritter e H. T. Tarrant. É claro que os partidários da autenticidade, por sua vez, não enxergam essa incompatibilidade - na verdade muitas vezes dizem que, filosoficamente, a carta é perfeitamente platônica - como Brisson, Bury e Nicholas White, conforme veremos mais abaixo.

As questões filosóficas em torno da carta se dividem em dois grupos: um, minoritário, vê problemas nas concepções políticas ali expostas, ou um conflito com ideias apresentadas em Leis ou na República; outro, majoritário, atribui todo o problema ás teses do excurso filosófico, especialmente no que diz respeito à teoria da linguagem. Passemos a examiná-las.

\subsubsection{O tratamento dado a Sócrates}

Um incômodo comumente manifestado pelos que defendem a espuriedade da carta é o tratamento dispensado a Sócrates - que consideram lacônico, pouco laudatório e diferente daquilo que julgariam apropriado por parte de Platão. Edelstein toma esse como um dos seus principais argumentos contra a autenticidade 
da carta, e Irwin dá a ele também bastante peso. Eis o que diz o texto da carta, literalmente (324d-325c, na tradução de José Trindade e Juvino Maia):

\begin{abstract}
Além disso, um amigo meu, mais velho, Sócrates, que eu certamente não me envergonharia de dizer ser então o mais justo de todos, mandaram-no com outros contra um dos cidadãos, conduzindo-o à força para a morte, a fim de que fosse cúmplice dos negócios deles, querendo ou não. Mas ele não se deixou persuadir, e arriscou-se a suportar tudo, em vez de se tornar cúmplice deles em atos ímpios. Considerando então todas essas coisas e ainda outras tais não pequenas, desgostei-me e afastei-me dos males de então. (...)
\end{abstract}

Mas calhou que alguns que detinham o poder levassem ao tribunal esse nosso companheiro, Sócrates, lançando a mais injusta acusação, que se aplicava menos do que tudo a ele. Pois, uns acusaram-no como ímpio, outros condenaram e mataram este que não quis participar de uma ímpia condução ao tribunal de um dos amigos deles (...).

A mim, que observava essas coisas e os homens que faziam política, quanto mais examinava as leis e os costumes e avançava em idade, tanto mais me parecia difícil ser correto o dedicar-me à política.

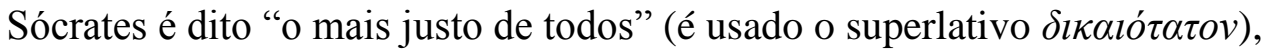
alguém disposto a "suportar tudo" e enfrentar a condenação à morte para não se

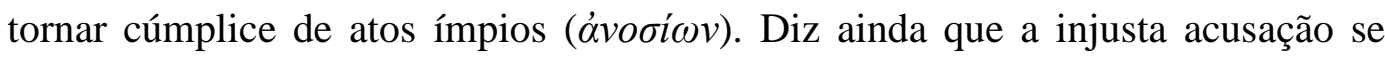
aplicava "menos do que tudo a ele". Irwin não só considera tal linguagem demasiado econômica, mas também observa a ausência de menções à virtude e à sabedoria de Sócrates (pp. 18 e 19). Propõe para isso uma comparação do trecho com o panegírico do Fédon, que o descreve como "o melhor, o mais sábio e o mais justo dos homens" (118a). Ora, não parece razoável dizer que a virtude de Sócrates

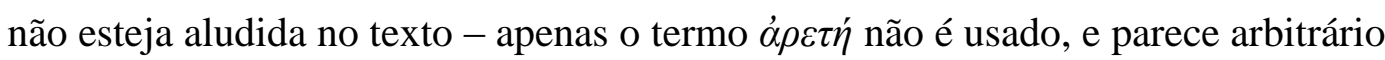
exigir que o fosse ${ }^{74}$. Além disso, é significativo o uso do mesmo superlativo nos

\footnotetext{
${ }^{74}$ Essa alegação de Irwin torna-se ainda mais curiosa à luz do diálogo Mênon, em que se discute se a justiça e a virtude são idênticas, ou se a justiça é uma das ocorrências da virtude (73d-74a).
} 


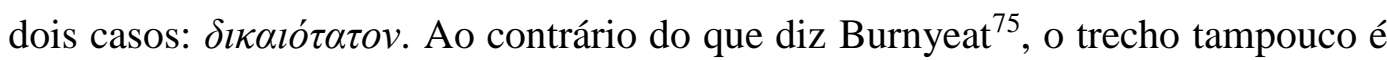
econômico ao descrever o impacto da morte de Sócrates sobre a vida de Platão: por conta dela, o jovem filósofo decidiu afastar-se da política e da vida pública, e convenceu-se do estado de corrupção generalizada da Atenas de seu tempo.

Edelstein, por sua vez, estranha o tratamento usado para se referir a

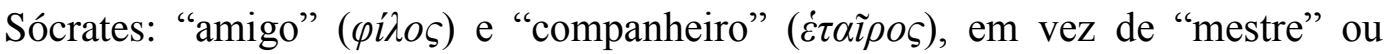
"professor". Não é difícil ver, com Brisson ${ }^{76}$, que isso se explica perfeitamente pelo contexto em que Sócrates está sendo mencionado, e novamente parece arbitrário cobrar que Platão usasse um tratamento específico em vez de qualquer outro, uma vez que tanto "amigo" quanto "companheiro" são formas evidentemente positivas de se referir a alguém. A essa observação, é possível acrescentar ainda outra: a de que, no mesmo panegírico do Fédon mencionado mais acima, o mesmo tratamento

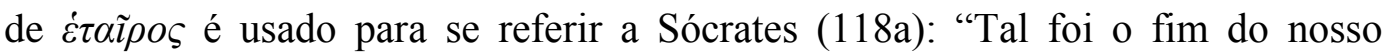
companheiro".

Não parece ser essa, portanto, uma razão sólida o bastante para rejeitar a autoria platônica da carta.

\subsubsection{Questões políticas gerais}

Michael Frede é o principal representante daqueles que veem problemas nas ideias políticas apresentadas na carta. Sua tese é simples e direta: a VII expressa acuradamente as ideias expostas na República, especialmente no que diz respeito ao governo dos filósofos e à virtude como pré-requisito para que o governante se desincumba de suas tarefas; o problema, diz Frede, é que, segundo a cronologia dos eventos, seria de se presumir que, na época da redação da carta, Platão já estivesse próximo de escrever o diálogo Leis, ou talvez mesmo já o estivesse escrevendo. Conforme se sabe, as posições políticas desse diálogo mitigam muitas das propostas

\footnotetext{
${ }^{75}$ Na p. 145, ele diz que Sócrates foi reduzido a "um mero exemplo". Diz ainda que Platão não relata as contribuições de Sócrates para sua formação filosófica. Dado o contexto daquilo que está sendo exposto - ou seja, uma notícia da participação de Platão na vida pública - não parece haver razão para que ele precisasse fazer tal relato.

${ }^{76}$ Op. cit., p. 142.
} 
apresentadas na República, talvez por conta de um ajuste "realista" que levasse em conta a dificuldade de implementar o regime ali descrito. Há quem defenda, aliás, que foram os eventos de Siracusa que o levaram a essa revisão em termos de filosofia política. Em Leis, é exposta a ideia de uma "segunda melhor opção" de governo - composto de uma assembleia, um conselho e de magistrados. Haveria ainda o Conselho Noturno, responsável por zelar pela observância da lei. E não existe em Leis nenhuma indicação explícita de que esses membros, nem mesmo os magistrados, precisassem ser filósofos. O texto de Leis, aliás, diz claramente que a proposta que está sendo apresentada pode ser chamada de "a segunda melhor" organização possível de um estado (V 739a-e e IX 875d). Diante disso, Frede diz que não seria razoável que Platão estivesse aconselhando a essa altura da vida um governo de filósofos em Siracusa, e diz não entender por que, diante dessas circunstâncias, não sugeriu aos aliados de Díon que tentassem uma "segunda melhor" solução (pp. 51 ss.).

É significativo que, dentre todos os partidários da espuriedade, essa questão tenha causado incômodo a Frede e apenas a ele. A todos os demais comentadores sempre pareceram razoáveis e perfeitamente compatíveis com o pensamento de Platão os conselhos e recomendações presentes na carta. Se é preciso se reportar à estranheza de Frede, pode-se observar uma série de coisas. A primeira: segundo a cronologia presumível (ou seja: entre o falecimento de Díon e o do próprio Platão), Leis estaria em elaboração na época da redação da VII. Nada indica que as ideias ali apresentadas já tivessem forma, e que Platão já estivesse plenamente comprometido com elas a ponto de aconselhá-las para o governo de uma nação. Em segundo lugar, ainda que essas ideias já existissem, é fácil perceber que República e Leis tratam de situações hipotéticas e de governos teoricamente concebidos, e que o aconselhamento concreto num caso específico comporte ajustes circunstanciais e eventualmente adaptações. Isso seria compreensível mesmo que os conselhos da carta se afastassem das ideias apresentadas na República - e, no entanto, nem esse é o caso. Mesmo depois de conceber Leis, e aliás conforme indica o termo "segundo melhor”, é perfeitamente razoável supor que Platão seguisse crendo que o governo de filósofos é a melhor opção para as nações, e que o recomendasse a quem solicitasse seu conselho. Enfim: no todo e no detalhe, as ideias políticas presentes 
na carta são caracteristicamente platônicas e de fato poucos foram os intérpretes que viram problemas ao vê-la sair da pena do filósofo.

\subsubsection{O excurso filosófico}

Passemos, então, às questões que incomodaram Edelstein, Irwin e Burnyeat a ponto de fazê-los rejeitar a autenticidade da carta. Conforme se sabe, a certa altura do texto, e por razões que precisam ser devidamente contextualizadas, Platão começa a tecer considerações sobre o caráter "frágil" do discurso (o termo usado é $\dot{\alpha} \sigma \theta \varepsilon v \dot{\eta} \varsigma$ ), e sua impossibilidade de descrever certas realidades. Eis o contexto: o filósofo foi convencido a voltar a Siracusa para ter com Dionísio II, e o foi porque chegavam notícias de que o tirano estava transformado, e havia desenvolvido um grande entusiasmo pelos estudos filosóficos. Ainda hesitante, Platão foi ao encontro de Dionísio com a intenção de aplicar-lhe um "teste" que, segundo ele, costumava usar para provar aqueles que se apresentavam como candidatos aos estudos filosóficos - teste que consistia, basicamente, em expor uma espécie de programa de estudos, junto com todas as dificuldades e fadigas envolvidas no processo, e então observar a reação do aluno. O tirano malogrou no teste - deu-se por satisfeito com a lição preliminar, e não houve segundo encontro. Platão decide retornar prontamente a Atenas, vendo confirmadas as suas suspeitas. Tempos depois, ouve dizer que Dionísio havia publicado um livro com aquilo que ouvira da sua filosofia, e desaprova enfaticamente a iniciativa. Ao apresentar suas razões, dão-se os motivos para a controvérsia. Eis o que diz (341b-d):

Sei que alguns outros escreveram sobre essas mesmas coisas, mas esses não sabem nem de si mesmos. Eis o que eu tenho a explicar acerca de todos que escreveram e hão de escrever, quantos dizem saber acerca daquilo de que me ocupo, tanto os que me ouviram a mim, como a outro, como ainda os que encontraram por si. Não é possível, na minha opinião, que tenham compreendido nada do assunto. Não há obra minha escrita sobre ele, nem jamais poderá haver. Pois, de 
modo algum se pode falar disso, como de outras disciplinas, mas, depois de muitas tentativas, com a convivência gerada pela intimidade, como um relâmpago brota uma luz que nasce na alma e se alimenta a si própria.

Críticas ao discurso escrito não são uma novidade na obra de Platão - o diálogo Fedro traz uma série de famosas considerações a esse respeito, embora as razões aludidas sejam bastante distintas. A primeira estranheza relatada pelos comentadores se dá em relação ao raciocínio apresentado: o trecho se inicia expondo as limitações do discurso escrito, mas termina por defender a impotência do discurso em geral. O mesmo aliás vai se dar ao longo da exposição, conforme veremos. O autor da carta então diz ser oportuno aprofundar-se na questão e explicar melhor a fragilidade dos lógoi. Dá-se para isso o "excurso filosófico" uma breve exposição que tange a ontologia, a teoria do conhecimento e a filosofia da linguagem.

São duas páginas e meia na numeração Stephanus, um trecho relativamente sucinto e mesmo algo lacônico, mas potencialmente de imensa importância. Em primeiro lugar, merece menção o fato de que a explicação ali apresentada, notavelmente simples, sintetiza num breve trecho questões de natureza linguística, epistemológica e ontológica - o que tocaria o próprio cerne da filosofia platônica e ajudaria a lançar luz sobre uma parte significativa dos diálogos. Passemos a uma breve exposição do que é dito.

Há em cada um dos entes (o termo grego é óv $\tau \alpha$ ) três elementos (a palavra "elementos" é nossa, pois o original diz apenas "três") que dão ensejo ao conhecimento:

1. O seu nome.

2. Um lógos que explique o que ele é; presumivelmente e pelo exemplo dado, esse lógos seria o que chamamos de "definição".

3. A coisa mesma, ou a sua apresentação sensível.

Esses três elementos levam a um quarto: 
4. O conhecimento que temos da coisa, portanto uma entidade que chamaríamos de intra-mental. Diz literalmente o texto: o quarto é "o conhecimento, a inteligência e

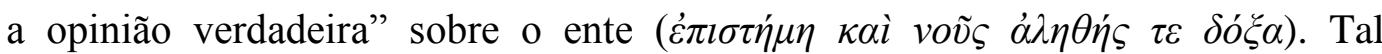


se refere ao seguinte.

5. O ente em si mesmo. Em momento algum o texto menciona "formas" ou "ideias", mas fala claramente como exemplo do "círculo-em-si" (342c), com as características de imutabilidade e de indestrutibilidade que as formas platônicas de fato têm.

São feitas então algumas afirmações sobre toda essa estrutura: os quatro primeiros elementos são distintos do quinto, ou do ser em si mesmo; as três primeiras são mutáveis e fugidias em relação à quarta (o conhecimento), que é a que mais se aproxima da realidade em si mesma, e que com ela se relaciona por

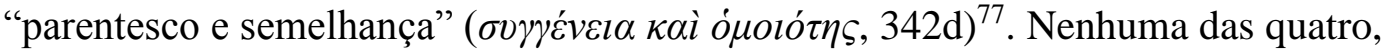
no entanto, é idêntica à quinta.

Eis as razões aludidas: os nomes têm natureza convencional e podem variar. Um círculo poderia ser chamado de "quadrado", desde que mantido o seu referente. Os lógoi, ou definições, são formados por nomes, e se contaminam também da sua imprecisão. Os entes sensíveis são mutáveis e imperfeitos, e contêm tanto a própria natureza quanto aquilo que lhe é contrário - o círculo desenhado ou feito no torno "é tocado pela reta em toda parte", e nenhuma manifestação sensível do círculo jamais será perfeita como o círculo-em-si (305a). Por fim, o nosso conhecimento tende a dar demasiada atenção aos entes sensíveis, e, portanto, com frequência se atém a um $\pi o i o ́ v$ ou qualidade da coisa, e não ao $\tau o ̀$ őv de cada uma delas.

A maior parte dos comentadores viu na exposição acima a apresentação de ideias perfeitamente compatíveis com tudo o que conhecemos da filosofia de Platão, e com o que podemos depreender do resto da sua obra. Bury, por exemplo, diz: "No que diz respeito à exposição filosófica em si mesma, pouco ou nada há que não esteja expresso ou implicado das afirmações sobre o idealismo contido nos

\footnotetext{
${ }^{77}$ Bury notou que o uso desses termos ecoa o modo de expressão da República 490b. Op. cit., p. 532, n.2.
} 
diálogos de Platão."78 Nicholas White não só defendeu a "ortodoxia" das ideias ali expostas, mas também a apresentou como um natural desenvolvimento da investigação levada a cabo no Mênon, no Teeteto e no Sofista, e na verdade como solução explícita para o problema da dependência mútua entre linguagem e conhecimento $^{79}$. Pasquali viu justamente no excurso o "selo platônico da carta", algo que antes provava a sua autenticidade ${ }^{80}$.

No entanto de fato houve os estudiosos que viram não só discrepâncias, mas mesmo incompatibilidades irreconciliáveis em relação ao resto do corpus platônico. Vamos a seguir explorar essas questões, e sugerir comentários críticos em relação a elas.

O principal ponto de dificuldade levantado se concentra na questão das definições, ou no segundo dos elementos do conhecimento que a carta propõe: a transferência da instabilidade dos nomes para as definições. Irwin ${ }^{81}$ argumenta que esse é não só um equívoco crasso em termos filosóficos, mas um equívoco que o próprio Platão já havia superado no diálogo Crátilo, em 385b-386e: ali já estaria estabelecido que a variabilidade dos nomes não afeta suas definições. Faz-se necessário, aqui, recorrer ao trecho aludido (na tradução de Carlos Alberto Nunes):

$\mathrm{H}:$ (...) posso designar qualquer coisa pelo nome que me aprouver e dar-lhe, e tu, por outro nome que lhe atribuíres. O mesmo vejo passar-se nas cidades, conferindo por vezes cada uma aos mesmos objetos nomes diferentes, que variam de heleno para heleno, como dos helenos para os bárbaros.

S: Então, vejamos agora, Hermógenes, se és também de parecer que com os seres se dá o mesmo, possuindo cada um a sua existência particular, como dizia Protágoras (...)

S: Ora, se as coisas não são semelhantes ao mesmo tempo, e sempre, para todo o mundo, nem relativas a cada pessoa em particular, é claro que devem ser em si mesmas de essência permanente; não estão em relação conosco, nem na nossa dependência, nem poderiam ser

\footnotetext{
${ }^{78}$ Op. cit, p. 472.

${ }^{79}$ WITHE, N. P. Plato on knowledge and reality, cap. 8.

${ }^{80}$ PASQUALI, G. Le lettre di Planone. Florence: Felice Le Monnier. 1938. p.67.

${ }^{81}$ Op. cit, p. 32.
} 
deslocadas em todo os sentidos por nossa fantasia, porém existem por si mesmas, de acordo com sua essência natural.

Conforme se vê, o trecho não trata em momento algum de uma relação da estabilidade das definições, mas apenas expõe um claro contraste entre a convencionalidade dos nomes e a natureza mesma dos entes. Seria possível discutir se essa "essência natural" aludida diz respeito ao "nível 3" ou ao "nível 5" de realidade aludidos na carta - ou seja, se diz respeito aos sensíveis ou aos inteligíveis - mas é certo que não há aí nenhuma discussão sobre a natureza das definições ou das proposições. Ainda que o argumento da transferência de instabilidade seja ruim, como diz Irwin, não é correto dizer que ele seja uma questão que tenha sido superada por Platão no trecho aludido. Irwin talvez tivesse mais chances de encontrar a superação da questão no diálogo Sofista, mas também isso daria azo a discussões.

Essa observação, claro, não encerra a questão: dizer que Platão não havia explicitamente elucidado um problema filosófico não é o mesmo que afirmar que cometeria deslizes a esse respeito. E o erro, segundo alguns, é demasiado grave: Burnyeat considera o raciocínio sobre as definições tão precário e ininteligível que seria indigno não apenas de Platão, mas mesmo de qualquer pessoa com o devido treino filosófico ${ }^{82}$ - razão que o fez crer que a carta tenha sido redigida por um escritor que tentava se passar por um filósofo, como quem manejasse conceituação e termos que não compreendesse. Cremos ser possível dar ao trecho uma leitura mais generosa, conforme veremos abaixo. Mas, antes, reportemo-nos a outro problema.

Ao discorrer sobre o que afasta os quatro níveis de realidade do quinto, o texto diz, literalmente: “esses elementos realizam a qualidade ( $\tau$ ò $\pi \circ \iota o ́ v)$, mostrando algo acerca de cada coisa, mas menos do que o ser de cada uma delas, devido à fragilidade do discurso". O raciocínio de fato soa estranho: embora a distinção entre um aspecto ou qualidade de um ente e o ente em si mesmo seja perfeitamente platônica, e remeta ao Mênon (71b) e ao Eutífron (11a-b), é difícil compreender por

\footnotetext{
${ }^{82}$ Op. cit., pp. 122-123.
} 
que ela pode ser integralmente creditada à fraqueza dos discursos. Além disso, se nos ativermos ao terceiro nível de realidade (o ente sensível ele mesmo), sua dessemelhança em relação ao em-si se deve ao próprio modo de ser constitutivo do mundo material, não a um fator linguístico qualquer.

Ambas as questões podem ser respondidas, segundo nos parece, se são levados em conta o próprio contexto da carta, os destinatários a que ela se reporta, e o propósito específico do trecho em questão. Em síntese, é possível dizer que o cerne das ideias apresentadas é, de fato, perfeitamente platônico: uma clara distinção entre o sensível e o inteligível, as características atribuídas a cada um, a precariedade das nossas tentativas de descrevê-los, as dificuldades envolvidas no conhecimento das realidades em si mesmas, e a intuição intelectiva que nos leva a contemplá-las. Na verdade, mais do que "perfeitamente platônica", a explicação é notavelmente semelhante a um trecho de Leis - que seria, presumivelmente, uma obra da mesma época que a carta. Vale a pena citá-lo na íntegra (895d-896a, na tradução de Carlos Alberto Nunes):

\author{
A: Por Zeus! Em tudo o que existe não reconheces três \\ coisas? \\ C: Como assim?
}

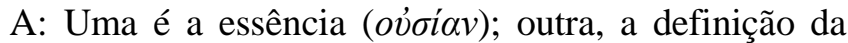

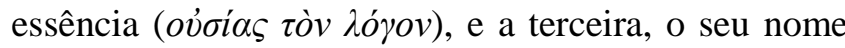
(óvo $\mu \alpha$ ). Além disso, a respeito de todos a respeito de todos os seres podem formular-se duas questões.

C: Duas, como?

A: Ora apresentamos o nome e pedimos a definição, ora formulamos primeiro a definição e, a seguir, inquirimos do nome.

C: Com isso, não queremos exprimir o seguinte?

A: Que poderá ser?

C: Certas coisas, e alguns números, podem ser divididos em dois. Quando se trata de número, dizemos que é par, vindo a ser sua definição: todo número divisível em duas partes iguais.

A: Certo; assim mesmo é que eu penso. Mas, não diremos a mesma coisa tanto num caso como no outro, 
quando nos pedem a definição e damos o nome, ou depois do nome damos a definição, designando a mesma coisa de duas maneiras diferentes, pelo nome, que é par, e pela definição: o que pode ser dividido em duas partes iguais.

C: Perfeitamente.

A: E agora: que definição corresponde ao nome de alma? Haverá outra, a não ser a que apresentamos há pouco: o movimento capaz de movimentar-se?

Os paralelos entre o excurso filosófico e esse trecho não escaparam à maior parte dos comentadores. Os três elementos de cada ente estão aí claramente enumerados da mesmíssima forma como na VII, e Leis apenas não se reporta aos outros dois, porque não está, no momento, investigando a natureza do conhecimento e nem o estatuto das formas inteligíveis - está apenas tecendo algumas considerações sobre a psique humana, e para isso precisa aludir à questão das definições. Burnyeat observou que, no trecho, não há registro de que as definições sejam em si problemáticas, e a discussão toma como ponto pacífico que elas expressem a natureza da coisa definida - como aliás em trechos de outros diálogos. Mas tampouco o discurso humano e a natureza das definições está em jogo aí. A menção de Leis aos três elementos é muito mais sucinta, e feita de passagem, mas suficiente para que se enxergue o evidente parentesco com a carta, e para que vejamos na distinção, de fato, um "selo" platônico.

Se o cerne do argumento é decididamente platônico, o que é que explica os seus dois pontos mais problemáticos - a saber, a transferência da instabilidade das palavras para as definições e a atribuição de todo o problema do conhecimento humano à fraqueza dos lógoi? A resposta nos parece ser: isso pode ser explicado por uma leitura mais ampla e contextualizada, e, portanto, a partir de uma interpretação mais generosa do trecho. Expliquemos: todo o excurso filosófico vem em socorro da recriminação que Platão dirige a Dionísio II pela iniciativa de publicar um livro sobre assuntos que não dominava. Para justificar essa recriminação, ele diz que certos conhecimentos só se atingem mediante "muitas tentativas, com a convivência gerada pela intimidade", quando então "como um relâmpago uma luz brota na alma" do aprendiz (341c). Alude então, a seguir, à 
necessidade de selecionar bem os discípulos com os quais tratar de certos assuntos mais elevados. E faz referência também ao fato de nem mesmo ele ter jamais escrito sobre os mesmos assuntos, por conta de limitações do próprio gênero escrito, e pela própria dificuldade de pô-los em forma registrada.

O autor diz então uma frase altamente significativa, e no entanto pouco explorada pela tradição de comentários (342a): "Veio-me à mente falar mais longamente acerca disso, pois, talvez fique mais claro, à medida que me for explicando." Na tradução de José Trindade e Juvino Maia, "veio-me à mente" traduz o verbo grego $v \tilde{\omega}$, que, nesse contexto, comportaria algumas possibilidades: Bury opta por I am minded to; Brisson, por j 'ai l'intention; León Robin, por il m 'est venu à l'idée; L. A. Post, por it has ocurred to me. Seja qual for a tradução dada, há algum sentido em torno de "ocorre-me", "vem-me à mente" - o que dá a ideia de que o autor, no momento em que redigia, resolveu repentinamente abrir um parêntese e condescender a uma breve explicação, apenas para fins de esclarecimento tópico. Não é à toa, portanto, que o excurso ganhou esse nome, e não à toa o trecho é tão claramente demarcado no início e no fim. Ao encerrá-lo, aliás, diz o texto (344d): "Quem abarcou esta história e a digressão ( $\pi \lambda \dot{\alpha} v o \varsigma)$ ". Tratase de uma tergiversação em um texto que tem, declaradamente, propósitos bem outros que os de lecionar sobre ontologia, teoria do conhecimento e filosofia da linguagem. Platão está colateralmente aludindo a uma série de questões complexas e intricadas sobre a relação entre o lógos, a epistéme e a realidade, e apenas o suficiente para indicar que Dionísio foi imprudente ao publicar sua obra filosófica. Sabemos que Platão de fato conhece e tematiza esses problemas. Em uma carta, especialmente dirigida a um público não treinado e não necessariamente interessado em filosofia, e que tem como intuito declarado a precipitação de uma ação política (e possivelmente o intuito de apresentar uma apologia pro vita sua), as minúcias a que desce o excurso, como estão, já podem soar excessivas. Esperar que ele entrasse em delicadas considerações metafísicas e avançasse toda uma teoria da predicação, como faz no Sofista, talvez seja mesmo falta de sensibilidade interpretativa, e certamente uma leitura que desconsidera inteiramente o contexto.

Os mesmos escrúpulos interpretativos dão conta ainda de uma outra objeção reincidente: a que diz respeito à frase (343a) "ninguém que tenha juízo ousará expor pela linguagem o seu pensamento, por causa de sua fragilidade, e isso em caracteres 
imóveis, como acontece com a escrita". Conjugada com o resto da digressão, ela soa não como uma condenação da escrita, como aquela que aparece no Fedro, mas como uma condenação da linguagem verbal como um todo, e quase que a proposição da existência de um abismo intransponível entre lógos e realidade. É possível, com Brisson ${ }^{83}$, interpretar a frase como simplesmente dizendo que há dificuldades graves na tarefa de transpor para a linguagem certas intelecções superiores - o que aliás é compatível com as considerações presentes na famosa "passagem da linha dividida" da República. A frase parece estabelecer uma clara hierarquia, como quem dissesse: se é difícil falar sobre essas coisas, $\kappa \alpha i ̀ ~ \tau \alpha \tilde{v} \tau \alpha \varepsilon ı \varsigma$ $\dot{\alpha} \mu \varepsilon \tau \alpha \kappa i v \eta \tau o v$, ou seja, "ainda mais quando em < caracteres> imóveis". A ideia é perfeitamente compreensível e, ademais, compatível com o que conhecemos de Platão; se mais não é dito ou explicado, é certamente por não se tratar da ocasião para isso.

Por fim, registre-se uma última consideração, para fins de esgotamento da questão. Em obra de 1910, Constantin Ritter ${ }^{84}$ chegou a levantar a hipótese de que a carta inteira seja autêntica, mas que o excurso filosófico seja uma interpolação posterior acrescentada por algum discípulo ou membro da academia que tenha querido deixar mais clara e mais enfatizada a recriminação ao livro de Dionísio II. H. T. Tarrant ${ }^{85}$ reapresentou a mesma hipótese em um artigo que mostra a compatibilidade entre o pensamento médio-platônico e a epistemologia da carta ${ }^{86}$. As razões aludidas por ambos são em grande parte semelhantes às dos partidários da espuriedade: problemas com a conteúdo da digressão. Se houvesse meios de confirmar a hipótese de autoria diversa para o trecho em relação ao resto da carta, isso reconfiguraria inteiramente a discussão, já que desapareceria o principal argumento para considerar a carta como apócrifa - na verdade, o cerne das razões de Edelstein, Burnyeat e Irwin. Uma interpretação generosa e contextualizada, segundo nos parece, torna a hipótese desnecessária. No entanto, uma análise

\footnotetext{
${ }^{83}$ Op. cit., p. 150.

${ }^{84}$ RITTER, C. Platon. Minuque: Beck, 1910.

${ }^{85}$ TARRANT, H. "Middle platonismo and the Seventh Letter". In Phronesis 28, 1983, pp. 75-103.

${ }^{86}$ Andrew Hull defendeu hipótese bem semelhante em tese de doutorado escrita em 2012, intitulada

"The mystery of the Seventh Platonic Epistle: An analysis of the philosophic digression", do Departamento de Clássicos da Emory College. Pretende com isso afirmar que a digressão é um relato sucinto das "doutrinas não-escritas" cultivada na Academia posterior.
} 
estilométrica que comparasse os trechos internos da carta poderia certamente ajudar a esclarecer a questão - mas tal trabalho ainda está para ser feito.

A esse respeito, há uma observação que merece a nossa atenção. Existe uma curiosa inflexão de estilo no momento em que o texto adentra o excurso filosófico: conforme notou Brisson ${ }^{87}$, o autor abruptamente deixa de se dirigir à segunda pessoa do plural, como quem de fato falasse aos parentes e companheiros de Díon, e passa para a segunda pessoa do singular, como quem falasse a um "tu" específico. Tal inflexão se observa a partir dos imperativos $\lambda \alpha \beta \varepsilon ́$ (342b3) e vó $\sigma o v$ (342b4): “toma a coisa em um único caso e considera ${ }^{88 "}$. Essa inflexão poderia ter algumas explicações. A primeira, a de reforçar a tese de que se trata de um trecho espúrio, enxertado posteriormente. A segunda, levantada pelo próprio Brisson ${ }^{89}$, é a de que Platão apresenta ali, no início do excurso e com a explicação dos níveis de realidade, uma lição já tornada mecânica e automática de tão repetida. De fato, é dito textualmente que a passagem já foi dita por eles "inúmeras vezes" ( $\pi \circ \lambda \lambda \dot{\alpha} \kappa ı \varsigma$, 342a5) - e a semelhança dessa passagem com o trecho citado de Leis dá testemunho disso. Se essa hipótese está certa, o trecho poderia ser o registro de um trecho de lição que o autor apresentaria com certa frequência dentro da Academia aos seus alunos selecionados - fato que, por si só, seria de grande interesse, visto ser um acesso privilegiado a um tipo de ensino privado de que temos notícia, mas ao qual não temos acesso por absoluta falta de documentação.

\section{8. À guisa de conclusão provisória}

Um princípio metodológico foi apresentado como aquele adotado pela presente pesquisa: o de que é a tese da espuriedade, e não a da autenticidade, que precisa de provas convincentes ou terminantes para prevalecer. Por tudo o que foi exposto anteriormente, tais provas não parecem até aqui terem sido apresentadas a

\footnotetext{
${ }^{87}$ BRISSON, L. “A Carta VII de Platão: uma autobiografia?”, in Leituras de Platão. EDIPUCRS, Porto Alegre, 2003., p. 32.

${ }^{88}$ A tradução de José Trindade e Juvino Maia Jr. perde essa nuance e muda a pessoa do imperativo para a primeira do plural: "Demos um exemplo e pensemo-lo" (p. 91).

${ }^{89}$ Op. cit., pp. 32-33.
} 
respeito da Carta VII: não há razões historiográficas para duvidar da autoria; as variações de estilo literário e pedagógico em relação aos diálogos são perfeitamente compreensíveis; a análise estilométrica a mostra compatível com os demais texto de autoria comprovada da mesma época; e, por fim, uma análise filosófica do seu conteúdo, embora certamente envolva questões, não parece de forma nenhuma obrigante.

Claro que essas considerações não pretendem encerrar a controvérsia. A não ser que novos dados e documentos surjam, talvez seja impossível estabelecer com certeza absoluta a autoria da carta. A análise ponderada de todos os argumentos, no entanto, torna razoável a posição prudencial de tratá-la, até segunda ordem, como um escrito autêntico, de autoria de Platão.

Bury ${ }^{90}$ observou que, tanto em relação às cartas quanto aos demais escritos de Platão, a tradição interpretativa tende a passar por "modas", ou por "movimentos pendulares": da "hipercrítica" à "hipocrítica". O risco de tal tendência é o de comprometer a importância do estudo de documentos que são importantes em si mesmos, à parte e além da questão da autoria. Friedländer ${ }^{91}$ fez uma consideração que talvez seja o caso de ter em mente: durante quase um século, o estudo e a interpretação de uma obra de imensa relevância como o Parmênides foram obnubiladas por controvérsias sobre a sua autoria. Tempos depois, a obra passou a ser lida e interpretada independentemente dessa questão, até que a controvérsia foi posta em segundo plano e aos poucos esquecida. Nenhuma "prova definitiva" de sua autenticidade jamais foi oferecida, e, a partir de certo ponto, tampouco era exigida. Um movimento semelhante em relação à Carta VII seria, em muitos sentidos, bem-vindo.

Por fim, uma palavra para fins de esclarecimento. Os próximos capítulos desta pesquisa vão se dedicar a uma interpretação que pretende revelar a importância filosófica do texto da Carta VII, em níveis e sentidos diferentes. Em grande medida, tais interpretações independem da questão da autoria, e não seriam refutadas caso surgisse alguma prova definitiva de espuriedade - especialmente caso se confirmasse a hipótese do "forjador próximo". Claro que uma prova dessa

\footnotetext{
90 p. 392.

91 p. 237.
} 
natureza nuançaria imensamente a questão, e exigiria uma reavaliação das hipóteses levantadas - mas, segundo cremos, elas ainda assim poderiam ser oferecidas como vias de interpretação.

Superada enfim, na medida do possível, a questão incontornável, podemos nos debruçar sobre a dimensão filosófica da carta. 


\section{3. "Conhece-te a ti mesmo" e o surgimento da noção abstrata de rò aúró na cultura grega}

\subsection{O surgimento do gênero autobiográfico em contexto filosófico}

O propósito do capítulo que se segue é o de dar subsídio para a defesa de uma hipótese: a de que a Carta VII nos dá o testemunho de uma transformação na maneira como o indivíduo humano compreendia e experimentava a si próprio transformação resultante, em parte, do próprio exercício da filosofia e, em parte, das mesmas condições culturais que a tornaram possível. Não cremos ser mera coincidência que o discurso autobiográfico surja neste momento da cultura grega, e nem tampouco que o mais antigo texto desse teor de que dispomos tenha sido escrito por ninguém menos do que Platão, justamente o pensador que, em grande medida, reconfigurou a maneira de compreender o indivíduo ontológico em geral, e que propôs ideias filosóficas inteiramente novas sobre o estatuto da individualidade humana. Também não à toa, foi o filósofo que, conforme veremos nas páginas a seguir, promoveu a apropriação filosófica do imperativo délfico "conhece-te a ti mesmo", tornando-o uma questão a ser investigada dialeticamente. De alguma maneira, o discurso em que o autor dá conta de si próprio como objeto de relato e de investigação é a consumação última desse imperativo, uma vez tornado questão filosófica.

As coisas, no entanto, não são tão simples. A máxima exibida no pórtico do Oráculo de Delfos surgiu na cultura grega durante o período arcaico, e aos poucos ganhou imensa centralidade como preceito de vida, tanto num sentido político quanto num sentido ético e religioso mais amplo. Houve condições para que tal surgimento se desse e tal centralidade se estabelecesse. Depois disso, passaram-se alguns séculos até que ele se tornasse uma questão filosófica. Uma observação se insinua desde o princípio: a máxima não tem um significado óbvio nem evidente, $\mathrm{e}$ na verdade são numerosos os indícios de que ela tinha um sentido determinado na cultura grega pré-filosófica, sentido bastante diferente daquele que acaba por lhe atribuir Platão. A questão naturalmente esbarra na maneira como é compreendido o verbo grego $\gamma l \gamma \nu \omega ́ \sigma \kappa \omega$, “conhecer" - que certamente sofreu profundas 


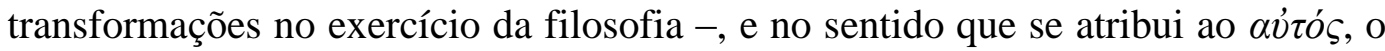
"si mesmo" a ser conhecido. Será necessário, portanto, alguma exposição sobre o histórico da compreensão da individualidade humana ao longo da cultura grega, e das interações que essa compreensão teve com o exercício da filosofia, direta ou indiretamente.

As considerações que se seguem partirão de um pressuposto: a de que a Carta VII é um dos mais antigos textos autobiográficos da cultura grega, e também de toda a História humana. A afirmação comporta espaço pra alguma controvérsia: em que medida deveríamos negar o caráter autobiográfico do relato que abre $O s$ trabalhos e os dias, de Hesíodo? E os relatos de Tucídides em sua História da guerra do Peloponeso? E a Apologia de Sócrates, do mesmo Platão? Ou mesmo certos exemplares da poesia lírica, profundamente intimista e pessoal?

Apontar um documento específico como sendo o mais antigo exemplar de texto autobiográfico de que dispomos pode ter algo de arbitrário, e há de se basear em algum critério específico. No caso, sigo aqui os critérios estabelecidos por Luc Brisson, em seu artigo “A Carta VII de Platão: uma autobiografia?”"92, e por Philippe Lejeune, em Le pacte autobiografique ${ }^{93}$. Dizem eles que, para que um texto possa ser considerado autobiográfico, é indispensável que um determinado "eu” seja, ao mesmo tempo, o autor, o narrador e o personagem principal da sua narrativa. $\mathrm{O}$ texto, portanto, precisa ser escrito na primeira pessoa do singular; o autor precisa ser o mesmo "eu" aludido no texto; por fim, o mesmo "eu" autor deve também ser o objeto principal da narrativa. Vê-se que cada um dos textos mencionados acima não observa pelo menos uma das condições.

Essa constatação evidentemente não pretende minimizar a importância dessas obras como precursores relevantes do gênero, mas apenas apontar que a Carta VII parece, de fato, inaugurar uma possibilidade de pensamento e de expressão na cultura grega. Mencione-se ainda que, pelos mesmo critérios, o texto Sobre a troca, de Isócrates, aparentemente escrito em 353 a.C., e, assim, contemporâneo da Carta VII, também poderia ser considerado uma autobiografia. Trata-se de um texto notoriamente inspirado na Apologia de Sócrates, tanto no

\footnotetext{
${ }^{92}$ BRISSON, Luc. “A Carta VII de Platão: uma autobiografia?”, in Leituras de Platão. EDIPUCRS, Porto Alegre, 2003.

${ }^{93}$ LEJEUNE, Philippe. Le pacte autobiographique. Paris: Le Seuil, 1975.
} 
estilo quanto no conteúdo, e que por isso participa de um contexto cultural não muito distante do da obra platônica.

Acrescente-se ainda uma observação apenas para fins de ênfase: o que afirmamos é que a Carta VII é um dos mais antigos exemplares de relato autobiográfico de que dispomos. É fato notório que a maior parte dos escritos que circulavam na Antiguidade se perdeu, e seria descabido afirmar que a epístola de Platão foi "o" mais antigo texto com esse caráter que jamais foi composto. É quase certo que relatos de semelhante teor tenham sido escritos antes dele - apenas que nenhuma cópia chegou até nós. Seja como for, nada disso diminui a importância e o significado da VII como testemunho de acontecimentos decisivos na história da cultura e do pensamento gregos.

Talvez a mera informação de que a Carta VII é a mais antiga autobiografia de que temos notícia na cultura grega seja suficiente para que se intua a importância extraordinária do documento. Trata-se de algo muito maior do que a mera invenção de um gênero literário, ou de uma mera curiosidade histórica. Esse texto parece indicar que existe algo de muito importante acontecendo com a noção de "indivíduo" no momento em que se abre a possibilidade de que alguém componha uma narrativa que fale da sua própria vida, no momento em que ele enxerga na sua própria trajetória individual um tema digno de relato e, mais do que isso, de investigação. A importância desse surgimento é certamente agravada se o pusermos ao lado de outros espocares igualmente originais e igualmente decisivos da cultura grega - surgimentos esses que viriam a ser determinantes em todo o desenvolvimento da civilização ocidental posterior.

Eis aqui o ponto para o qual é preciso chamar atenção: o assombroso fato de, em um espaço de tempo relativamente curto, de menos de dois séculos, terem surgido, na mesma cultura, os discursos filosófico, historiográfico e autobiográfico. A presente pesquisa pretende apontar alguns caminhos para a compreensão desse notável espocar, e investigar a possibilidade de referir esses três fenômenos a um fundo comum, e, talvez, enxergá-los como instanciações diferentes de um mesmo movimento, ou até de um mesmo fator causal. 
Se é verdade, conforme defende I. Meyerson ${ }^{94}$, que a memória não é um dado da experiência humana, mas uma difícil invenção, que consiste na conquista do passado, então torna-se evidente a importância, nesse processo, do surgimento dos discursos historiográfico e autobiográfico. As relações entre esses dois gêneros são, creio, bastante evidentes: o que o primeiro é no nível civilizacional, ou da nação, o segundo é no nível individual. O curioso é notar que em ambos os escritos inaugurais desses gêneros - as Historíai de Heródoto e a Carta VII de Platão - o que se dá é uma investigação de um estado atual, um perscrutamento do passado que dê conta de um certo estado presente de coisas. É conhecido de todos o

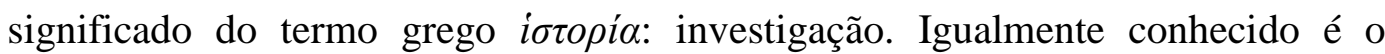
propósito de Heródoto ao empreender a sua obra: explicar relações, intensas, belicosas e problemáticas, entre o povo grego e o povo persa. O que costuma ser menos frisado é o fato de também a autobiografia platônica ser uma investigação para dar conta de uma certa configuração presente. No caso, Platão está explicando por que seu amigo Díon merecia sua confiança e seu apoio como ator político em Siracusa, e por que o penhor de um apoio a Hiparino II, sobrinho de Díon, ficaria condicionado à adesão dele a uma mesma visão moral e filosófica diante da pólis. Para explicar a gênese das ideias políticas que moveram a si próprio e a Díon, Platão narra então a história da sua vida - mais particularmente, a história da sua trajetória intelectual, em que os episódios narrados, como a condenação de Sócrates ou a primeira visita a Siracusa, integram-se perfeitamente à formação de um certo ideário político. Note-se então: a Carta VII não é exatamente um texto de memórias, como os que um autor contemporâneo escreveria ao fim de sua vida, em que a simples narrativa da trajetória biográfica é um fim em si mesmo. Ao contrário, o autor da epístola está ali apresentando uma justificativa de opções políticas que, até certo ponto, coincide com a narrativa da sua própria vida.

Além disso, a Carta é um indício de que o próprio "eu” havia se constituído como um problema filosófico digno de ser investigado, talvez depois de uma longa gestação, com importantes precursores na trajetória do pensamento grego, conforme veremos adiante. A natureza da individualidade humana acaba por se apresentar como um dos mais densos e sérios problemas filosóficos da própria obra de Platão - o lugar humano na economia cósmica, como na República ou no Timeu,

\footnotetext{
${ }^{94}$ MEYERSON, I. “Les temps, la mémoire, l'histoire”, Jounal de Psychologie, 1956, p. 335.
} 
e também o lugar e a função não do Homem, abstratamente falando, mas de cada indivíduo, como se evidencia em todos os mitos escatológicos que fazem menção a um julgamento no post-mortem - na conclusão do Górgias, ou no Livro X da República, ou no trecho central do Fedro. Uma narrativa autobiográfica tem um parentesco evidente com essa questão, ou ao menos com um dos seus aspectos - a busca por uma explicação que dê conta de um "eu” concreto, um "eu" vivido, que se manifesta e se dissolve no tempo.

Importa ressaltar a importância desse elemento. Nos antigos mitos, mereciam uma narrativa genealógica o próprio cosmos, os deuses, os heróis civilizadores. Na historiografia de Heródoto, já merecem-na reinos, impérios e seus

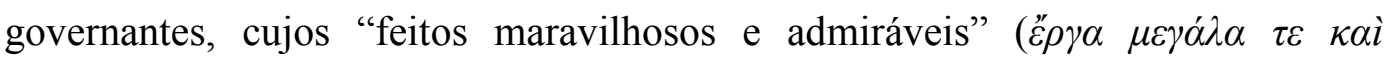
$\theta \omega \mu \alpha \sigma \tau \alpha \dot{)})$ devem ser lembrados (Livro I, 1). Na Carta VII, algo novo parece acontecer: o "amigo da sabedoria" narra a sua vida, não necessariamente porque ela seja grande e digna de registro, mas porque ela é, como toda vida individual, ou como todo indivíduo, uma questão filosófica que, em certas circunstâncias, convida à investigação - ou mesmo à avaliação e ao julgamento. Eis a razão da insistência em um ponto: a Carta VII não é absolutamente um texto de caráter literário ou documental que é entrecortado por um excurso filosófico. A epístola é, ela toda, em toda a narrativa, uma obra de caráter filosófico, cujo objeto de investigação é o "eu" que efetiva e concretamente se manifestou. A questão filosófica em foco é: como vim a me tornar quem sou, por que escolhi viver a vida que vivo, por que elegi os ideiais de conduta e de política que defendo. Esse é, creio, o ponto em que é possível seguir uma das pistas de investigação que podem aproximar o discurso autobiográfico da filosofia.

Nas páginas que se seguem, será necessário perseguir a intricada história da gradual formação da noção de "indivíduo" na Grécia Antiga, no sentido que essa noção ganhou em contexto filosófico. Só essa elucidação pode nos ajudar a lançar luz sobre a dimensão filosófica do mais antigo relato autobiográfico de que dispomos nessa cultura. 


\subsection{A longa gestação de uma noção filosófica, ou: conhecer o que, exatamente?}

Alguma noção de indivíduo ou de individualidade sempre esteve presente na cultura grega, antes ou depois do advento do pensamento filosófico. O pronome pessoal "eu" evidentemente existia na língua comum, e tinha um referente claro e intuitivo, diferente dos referentes dos pronomes "nós", "tu" ou "ele". No entanto, por trás do uso desse pronome, é certo também que a natureza desse referente pode sofrer transformações e inflexões - transformações e inflexões que acompanharão a compreensão da rede de relações que esse "eu" tem com o mundo que ele integra. Se por um lado é perfeitamente perceptível que a noção de individualidade sofre transformações ao longo da história grega, também não seria nada controverso afirmar que a noção de individualidade pessoal dos gregos, antes ou depois da prática da filosofia, nada tinha a ver com uma concepção moderna ou contemporânea, influenciada por todo um ciclo de pensamento e de cultura marcado, entre outras coisas, pelo legado do "eu pensante" cartesiano, pela sede das cognições kantiana, pelo advento da psicanálise etc.

Em sentidos bastante diferentes, tornou-se um lugar comum afirmar que o pensamento filosófico grego acabou por instaurar uma nova ideia de individualidade pessoal, ou que ele desvelou uma certa dimensão nova para a interioridade humana. Essa ideia foi apresentada de maneiras muito diferentes por filósofos, intérpretes e helenistas, e aquilo que de falam é comumente controverso e objeto de disputa. O resultado da afirmação, no entanto, parece convergir: a noção de "indivíduo" é um construto, de caráter ontológico ou metafísico, surgido na Grécia como resultado de uma certa configuração cultural e muito comprometida com o próprio exercício da especulação filosófica. Mas em qual sentido é realmente possível afirmar que algo como a individualidade humana foi instaurado em uma determinada cultura, em determinado tempo? A. A. Long chega a mostrar certo ceticismo diante da questão ao afirmar ${ }^{95}$ : “As pessoas já tinham selves antes da filosofia, muito embora os filósofos possam tornar difícil que entendamos isso".

\footnotetext{
${ }^{95}$ LONG, A. A. "Finding ondeself in Greek Philosophy", in Tijdschrift voor Filosofie., Nr. 2, Junho de 1992, p. 263. No original: People had selves, though philosophers can make it hard for us to realize this, before philosophy.
} 
Embora a ideia do surgimento de uma certa noção de individualidade seja um tópos, um lugar-comum nos estudos sobre a Grécia Antiga, a questão é altamente controversa. Estudiosos diferentes descrevem o fenômeno de maneira inteiramente diversa, dão a ele ênfases próprias, traçam quadros que às vezes se complementam, e às vezes se contradizem mutuamente. Perseguir essa questão e traçar um panorama claro não é tarefa simples. Como o tema se reporta muito diretamente à questão que estamos perseguindo - o surgimento do discurso autobiográfico -, será útil apresentar, nas páginas que se seguem, um inventário das teses propostas a esse respeito por alguns helenistas particularmente renomados. Da vasta literatura sobre o tema, optamos por selecionar alguns autores, pelo critério da agudeza e da influência exercida por suas análises na compreensão da cultura grega. Como as análises seguem caminhos bastante diferentes, vamos expor em linhas gerais em que consistem tais teses, e a seguir propor um arranjo crítico que sintetize alguns dos pontos que se reportarão mais diretamente à nossa análise da Carta VII.

Antes de prosseguirmos, no entanto, é necessário apresentar uma importante observação sobre método e sobre terminologia. Há uma dificuldade que paira sobre todo esse estudo: a de definir precisamente a natureza disso que foi instaurado. Os helenistas que se reportaram à questão nem mesmo estão de acordo quanto à terminologia: às vezes referem-se à formação da "noção de "indivíduo"; em outros casos, da "noção abstrata de sujeito"; em outros, da "dimensão da interioridade humana"; Snell fala ainda da descoberta do Geist, termo alemão bastante carregado que traduzimos como "espírito". Essas noções seriam no fundo as mesmas, apenas que se valendo de léxicos diferentes? A dificuldade não é trivial, e esbarra em um problema evidente: não há, na própria cultura ática, palavras que correspondam satisfatoriamente a nenhuma dessas noções. Por essa razão, nas páginas que se seguem vamos, em parte, respeitar a terminologia usada dos próprios autores aludidos - Snell falará da "noção abstrata de sujeito", ao passo que Schmitz usará o termo "dimensão de interioridade humana". De nossa parte, optaremos pela

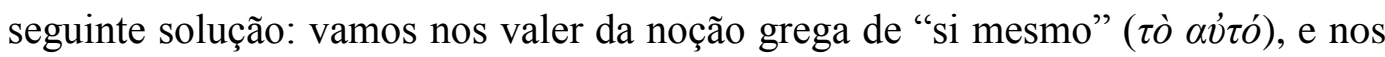
referir à inflexão do seu sentido até que ela se refira a um algo substancial que tornase objeto de cognição e de investigação filosófica. 


\subsubsection{Snell, Schmitz, Dodds: o surgimento da noção abstrata de "sujeito" e a internalização dos sentimentos}

De todos os helenistas cujas teses vamos analisar, Bruno Snell tem certamente aquela que é mais ousada, a mais radical, e, de alguma maneira, a que mais deixou marcas na compreensão do desenvolvimento da noção de individualidade na cultura grega. Em seu clássico $A$ descoberta do espírito, ou $A$ cultura grega e as origens do pensamento europeu ${ }^{96}$, ao dizer que a cultura grega gestou a noção de "alma” ou de "espírito" ao longo do período arcaico, ele não está de forma alguma se referindo meramente à descoberta de um certo elemento espiritual ou imaterial no ser humano. Antes, está afirmando que o que ali se instaurou (ou, seus termos, se "descobriu”) foi a noção de um indivíduo agente, uma unidade pensante e responsável por si - uma mesma unidade mental que seja sede das cognições, das percepções, das volições e das decisões humanas. Em sua formulação impactante e algo provocativa, Snell diz: "eles [os gregos] efetivamente criaram o que nós chamamos de "pensamento"",97.

A rigor, a tese de Snell é ainda mais forte e mais ousada, e aqui será preciso persegui-la desde o início.

Sua análise parte de um pressuposto metodológico: compreenderemos o desenvolvimento da cultura grega se formos capazes de uma análise acurada do próprio repertório vocabular e dos termos usados pelos poetas e demais autores para expressar suas experiências, suas relações com o mundo etc. Há, no entanto, uma dificuldade fundamental: vocábulos podem sobreviver durante longos períodos históricos, e é comum que seus significados sofram profundas transformações, sem que isso seja perceptível em uma análise superficial. Autores de épocas diferentes podem se valer de um termo como psuché para se referir a entes distintos, e tendo em mente referentes inteiramente apartados uns dos outros. Essa preocupação metodológica na análise do uso da língua poderia soar como típica do preciosismo dos estudos acadêmicos modernos e contemporâneos, e por isso mesmo Snell

\footnotetext{
${ }^{96}$ SNELL, B. A cultura grega e as origens do pensamento europeu. SP: Perspectiva, 2009. Embora tenha sido essa a tradução utilizada nas citações, preferimos nos referir à obra como $A$ descoberta do espírito, tradução mais direta e literal do título original Die Entdeckung des Geistes.

97 Op. cit., p. XVIII.
} 
chama atenção, logo nas primeiras páginas da sua obra, para o fato de que o filólogo alexandrino Aristarco havia estabelecido o princípio interpretativo de nunca tomar automaticamente o sentido de um termo homérico como sendo idêntico ao do grego clássico. O mesmo Aristarco havia notado, por exemplo, que o léxico $\sigma \tilde{\omega} \mu \alpha$ (corpo) nunca é usado na Ilíada para designar o corpo de uma pessoa viva, conforme acontecia na Grécia clássica, mas sim sempre para se referir a um cadáver ${ }^{98}$. Snell adota então o princípio de analisar cuidadosamente o contexto do uso dos termos, e de sempre discernir, na sua recorrência e na maneira como são usados, aquilo a que se referem - e, mais do que isso, aquilo a que não se referem.

A primeira afirmação de bastante peso feita por Snell é justamente essa: não existia, no grego dos tempos homéricos, uma palavra que designasse o corpo humano como totalidade unitária - e isso seria indicativo da ausência de uma noção de "unidade humana" como um todo. O mesmo Aristarco havia afirmado que o corpo vivo dos seres humanos era designado nos épicos homéricos pelo termo $\delta \varepsilon ́ \mu \alpha \varsigma$. Snell o refuta, chamando atenção para o fato de que a palavra é sempre usada no acusativo de relação, com a acepção de "porte", "estatura", para fins comparativos - acepção bastante distinta, portanto, da noção concreta de "corpo". Quando fazem alusão ao referente a que hoje chamamos por esse termo, os versos

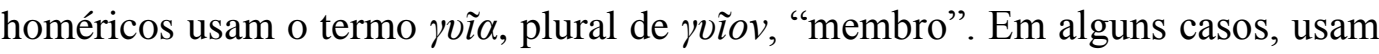
também $\mu \varepsilon ́ \lambda \varepsilon \alpha$, plural de $\mu \varepsilon_{\lambda} \lambda o \varsigma$, com o mesmo significado. É um fato estranho mas altamente revelador: Homero só se refere à corporeidade humana como uma pluralidade, um agrupamento, uma coleção articulada. Esclarece o filólogo: "Naturalmente que os homens homéricos tiveram um corpo como os gregos da época tardia, mas não o sentiam como um 'corpo', e sim, como um conjunto de membros"99. Como elemento comparativo que possa confirmar essa ideia, Snell chama atenção para as artes visuais do período, e para as imagens de heróis e guerreiros na pintura geométrica. Elas seriam a representação de uma articulação de partes, uma conjunção de membros - o que traz a nuance de um olhar diferente daquele que concebe primordialmente uma unidade, ainda que uma unidade que comporte um conjunto de elementos constitutivos. Não há nessas representações visuais, aliás, nem mesmo um centro articulador - como o tronco das

\footnotetext{
${ }^{98}$ Op. cit., pp. $1-2$.

${ }^{99}$ Op. cit., p.8.
} 
representações arcaicas e clássicas. Diz ele: “Às figuras da fase geométrica, ao contrário, falta exatamente essa parte principal; isto é, elas são autenticamente

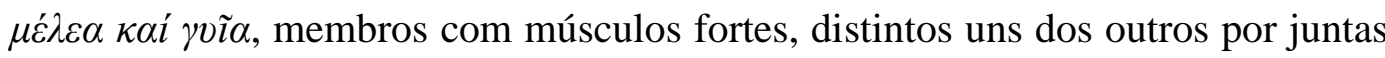
fortemente acentuadas.” E conclui: “os gregos dos primeiros séculos não concebem o corpo como unidade, nem na língua nem nas artes plásticas"100.

Essa mesma concepção do ente humano como uma "coleção" ou "articulação" se aplicaria, analogamente, a qualquer coisa que então pudesse ser chamada de "psique" ou "espírito". Ou seja: nada que designe a inteireza interior humana, e nem tampouco uma instância central que organize e articule os desejos, aspirações e pensamentos humanos. Em outras palavras: há a lacuna de uma vontade central que possa ser tida como sede da identidade humana. Nos atos mentais ou espirituais dos personagens, o que se vê é a influência direta de fatores externos, e os personagens como alvos vulneráveis para as inúmeras forças que sobre ele incidem e nele agem. O grego dos tempos homéricos, segundo Snell, desconhecia a noção abstrata de "sujeito".

Haveria aqui, alega o estudioso, uma perfeita analogia com o vocabulário que se refere ao corpo. Homero usa principalmente três palavras para o universo interior humano: $\psi v \chi \eta ́, \theta v \mu o ́ \varsigma$ e vóo - e nenhuma delas corresponde àquilo que entendemos pela alma pensante e senciente, sede da consciência e centro volitivo dos seres humanos. A primeira, $\psi v \chi \eta ́$, só é referida quando abandona ou está para abandonar os mortais - ou seja, em moribundos ou naqueles que desmaiam etc. Diz-se explicitamente que ela escapa pelas narinas ou pelas feridas de guerra daquele que morre. Parece um correlato anímico da noção de $\sigma \tilde{\omega} \mu \alpha$, que designava os cadáveres - ambos entendidos como resquícios, restos ou reverberações daquele que viveu. Pelo contexto e pelo uso do termo, seria impossível descobrir qual seria a sua função

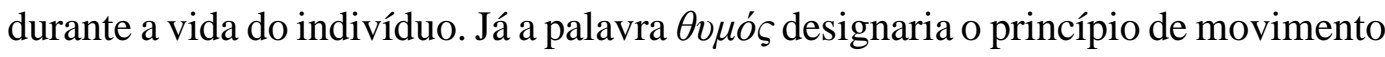
ou de agitação, ou o próprio motor da vida humana. Tais movimentos podiam ser internos ou externos - ou seja, as moções ou as emoções. Frequentemente o termo é usado em relação à morte, então descrita exatamente como a ocasião em que $\theta v \mu o ́ \varsigma$ se dissipa. Snell é enfático ao afirmar que $\theta v \mu o ́ \varsigma$ não existe depois da morte do sujeito, e que nem faria sentido falar de uma sobrevida individual desse "órgão da

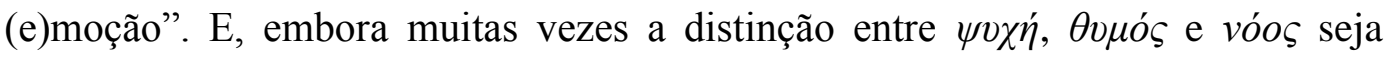

\footnotetext{
${ }^{100}$ Op. cit., p. 7.
} 
bastante obscura, Snell tipifica este último como sendo "quase um olho espiritual que vê com clareza"101 - órgão de algo próximo daquilo que chamamos de "percepção", tanto no sentido de "vislumbrar" quanto no sentido de "compreender" ou "dar-se conta".

Ao fim das considerações, Bruno Snell resume a questão da seguinte maneira: aquilo que chamamos de "alma" ou "psique" não tem no grego homérico uma correspondência exata, mas sim é referido por essas três instâncias distintas $-\psi v v \chi \dot{\eta}$, $\theta v \mu o ́ \varsigma$ e vóos. Elas exercem funções diversas, e parecem ser órgãos diversos, não inteiramente separados dos órgãos do próprio corpo. Nada haveria, como instância da interioridade humana, que pudesse ser a sede do caráter humano, ou a própria noção abstrata de "sujeito".

Um processo lento e gradual teve de se desenrolar até que essa concepção da alma se tornasse possível. Quando, alguns séculos mais tarde, Heráclito qualificar a psique humana como $\beta \alpha \theta \dot{v} \varsigma$, "profunda" ${ }^{102}$, isso será o resultado de uma longa elaboração levada a cabo pela poesia lírica - em que o termo $\beta \alpha \theta v ́ \varsigma$ já figurava para qualificar a sabedoria ou o pensamento. Hoje, pode nos parecer banal falar sobre a profundidade da alma humana, mas para um contemporâneo de Homero essa metáfora soaria como algo desprovido de sentido, tanto quanto falar sobre a profundidade de um pâncreas ou de uma mão.

O mesmo Snell afirma que, nos séculos subsequentes, são demasiado escassas

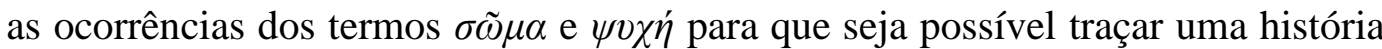
de desenvolvimento das noções de "corpo" e de "alma". O que sabemos é, no entanto, suficiente para inferir que elas ganharam forma amiúde como noções complementares, até chegarmos a uma concepção filosófica plenamente dualista na obra de Platão. Aparentemente nos tempos homéricos não se concebia a existência de uma alma distinta de um corpo, quaisquer que fossem as acepções atribuídas a essas noções.

Uma outra observação sobre o homem homérico diz respeito às suas ações e motivações. Modernamente, parecemos crer que as pessoas conduzem suas vidas e transformam suas situações por meio de um ato da sua própria vontade, algo que está sob seu próprio poder. Se, no entanto, examinarmos o texto homérico, talvez

\footnotetext{
101 Op. cit., p. 21.

102 Frag. 45, na tradução de Alexandre da Costa: "Não encontrarias os limites da alma, mesmo todo o caminho percorrendo, tão profundo logos possui."
} 
concluamos que existem outros modelos possíveis para compreender a ação humana. Não é difícil notar como os grandes heróis das epopeias - Aquiles, Heitor, Odisseu etc. - empreendem atos que não são exatamente a exteriorização de uma vontade, de uma força interior ou de um ímpeto individual.

Eis como Snell resume essa ideia, central para os nossos propósitos ${ }^{103}$ :

Toda vez que o homem faz ou diz algo a mais do que dele se poderia esperar, Homero, para explicar o fato, atribui-o à intervenção de um deus. E é o verdadeiro e autêntico ato da decisão humana que Homero ignora; daí por que, mesmo nas cenas em que o homem reflete, a intervenção dos deuses sempre tem uma parte importante.

Um exemplo esclarecedor quanto a isso se extrai da análise dos ímpetos que movem ou que detêm a ação dos personagens - e um caso emblemático quanto a isso é o conflito que se abate sobre Aquiles logo no início da Ilíada. Na querela que motivou toda a ação da epopeia, o herói, tomado pelo ódio, chega a cogitar desembainhar a espada e lutar contra Agamêmnon para recuperar a escrava Briseida. No momento crítico, há uma intervenção divina: Atena lhe aparece, lança sobre ele uma advertência e acaba por conseguir detê-lo. Aquiles obedece a deusa e embainha novamente a espada. Analisando esse episódio, Snell conclui:

A intervenção de Atena é, para nós, um elemento que mais atrapalha a motivação do que a torna aceitável; mas para Homero, a divindade, aqui, é necessária. Nós esperaríamos por uma "decisão", isto é, uma reflexão e uma ação de Aquiles; em Homero, porém, o homem ainda não se sente promotor da própria decisão; isso só ocorrerá na tragédia. (...) Em Homero, não existe a consciência da espontaneidade do espírito humano, isto é, a consciência de que as determinações da vontade e, em geral, dos movimentos do ânimo e dos sentimentos tenham origem no próprio homem. O que vale para os acontecimentos da epopeia vale também para o sentimento, o pensamento e a vontade: cada um deles tem sua origem nos deuses.

${ }^{103}$ Op. cit., p. 20. 
A alma humana, quer considerada como vóos, quer considerada como $\theta v \mu o ́ \varsigma$, é apenas um órgão, e não fonte, origem ou motor de nenhuma emoção. A psique concebida como primeiro movente, tal como a descreverá Aristóteles alguns séculos mais tarde, seria uma noção inteiramente estranha a Homero.

Essa dependência quase que absoluta de ações e motivações em relação aos deuses pode parecer algo estranho, ou mesmo terrível, para a nossa sensibilidade contemporânea, mas não era percebido dessa forma pela cultura grega nos tempos dos poemas homéricos. Ao contrário: se os heróis eram considerados grandes e notáveis, é porque os deuses agiam através deles. E, se a intervenção divina toma muitas formas, é porque os deuses homéricos são de fato múltiplos nas suas possibilidades de manifestação, na medida em que se confundem com a natureza mesma. Ou seja: quer do ponto de vista corpóreo, quer do ponto de vista espiritual, ou quer ainda do ponto de vista da ação propriamente dita, o ser humano na cultura grega tradicional e pré-filosófica era considerado como uma espécie de compósito resultante de uma série de incidências exteriores, e mesmo de algumas incidências que constituíam vetores contraditórios entre si.

Conforme já dito, a tese de Bruno Snell, segundo a qual a noção abstrata de "sujeito" ou de "indivíduo" foi gradualmente gestada na cultura grega ao longo do período arcaico, se tornou imensamente influente e estabeleceu um paradigma de análise para o desenvolvimento dessa cultura. É fácil vislumbrar o potencial revolucionário dessa tese: a noção de "indivíduo agente" pode ser vista, em nossa própria cultura, como uma noção universal, uma concepção instintiva e natural, presente em todos os povos em todos os tempos e em todos os lugares. A descoberta do espírito apresentou-a, ao contrário, como um construto específico de um determinado arranjo cultural. Teria havido, portanto, civilizações inteiras que não lidavam com essa noção, com todas as implicações que essa tese traria a reboque: implicações éticas, morais, religiosas, jurídicas, sociais, políticas etc. E talvez, antes de mais nada, as implicações mais relevantes sejam aquelas que possamos chamar de "ontológicas" ou "antropológicas" - ou seja, aquilo que estaria implicado na própria compreensão do que seja um indivíduo, em sentido metafísico, e na compreensão do que seja o ente humano. Algumas das teses de Snell foram corrigidas, debatidas, marginalmente contestadas, mas a sua hipótese da instauração 
da unidade humana, corpórea e psíquica, durante o período arcaico ainda segue imensamente influente, em que pesem algumas tentativas de refutação ${ }^{104}$.

A partir dessa pedra fundamental lançada por Snell, outros filólogos, helenistas e pesquisadores quiseram desenvolvê-la e explorar os seus desdobramentos. Certos pontos levantados por dois deles serão mencionados aqui, apenas como complementos e aplicações locais dessa tese central: algumas teses de Herman Schmitz e outras de E. R. Dodds.

Em sua obra System Der Philosophie ${ }^{105}$, embora apresente algumas críticas à maneira como Bruno Snell interpreta a noção de "alma" em Homero, Herman Schmitz aceita a tese central sobre o surgimento da individualidade humana na Grécia Antiga e a complementa com uma análise interessante e cheia de consequências: a tese da "introjeção dos sentimentos". Para ele, essa gradual “introjeção" é um processo peculiar e decisivo que se deu amiúde entre os tempos homéricos e a confecção da obra de Platão, intimamente ligado ao processo de “descoberta da alma" e, ao mesmo tempo, de paulatina "supressão do corpo". O segundo capítulo da obra é dedicado à exposição dessa tese, e apresentaremos de maneira muito breve nas próximas linhas o cerne da sua proposição e dos argumentos usados em seu socorro.

Schmitz afirma que os humanos primevamente experimentavam os sentimentos e as emoções como forças vindas do exterior e que sobre eles se abatiam. Eles eram descritos como a força de humores que incidiam corporeamente sobre as pessoas. Essas incidências alvejariam diretamente o coração, o peito, as entranhas - ou a $\varphi \rho \eta ́ v$ do indivíduo. E teria sido justamente mediante o desejo de opor alguma resistência a essas ocorrências (ou seja, ao tentar arrebatar alguma autonomia diante do fenômeno) que os gregos aos poucos desenvolveram a noção

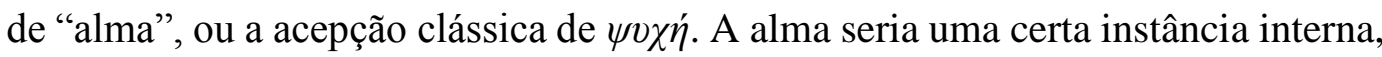
altiva e densa o bastante para resistir, em alguma medida, a essas investidas, e, portanto, capaz de resguardar, no ser humano, um relativo grau de autodeterminação e de controle sobre as próprias ações. Estaríamos ainda distantes de uma plena concepção de "livre arbítrio", mas certamente aí se lançariam as bases que a tornariam possível, ou mesmo filosoficamente concebível, mais adiante.

\footnotetext{
${ }^{104}$ Para um histórico das discussões ulteriores, debates a respeito etc., ver BREMMER, J. The Early Greek Concept of the Soul. Princeton: Princeton University Press, 1983. p. 8, nota 12.

${ }^{105}$ SCHMITZ, H. System Der Philosophie. Vol 2: Der Leib. Bonn: Studienausgabe, 1982.
} 
A alma, assim, embora não tivesse um locus particular, passou a ter a função de absorver as emoções corpóreas e transformá-las em "afecções". A partir de então, sentimentos passaram a ser concebidos como "afecções da alma", como humores, ou como estados anímicos. A antiga maneira de conceber emoções aos poucos desapareceu e foi esquecida. Em outras palavras, Schmitz concebe a "introjeção dos sentimentos" como um processo "centrípeto" de transpor para dentro do âmbito da psique a incidência de forças externas. O ser humano deixaria assim de ser como um objeto inerme, como uma pedra que rola ribanceira abaixo, como mera resultante das forças do entorno, e ganharia um centro de resistência e, portanto, de autonomia.

Um exemplo de como o herói homérico percebe e experimenta a incidência de sentimentos pode ser visto em um episódio da Ilíada - no diálogo entre Páris e Helena, logo depois do duelo com Menelau. Helena manifesta profunda vergonha diante do fato de que o marido não levou a cabo o combate, e pede a Páris que volte a campo e o retome. O herói então dirige as seguintes palavras a sua esposa (versos 441-446, na tradução de Frederico Lourenço):

\footnotetext{
Mas vamos agora para a cama e voltemo-nos para o amor. Nunca desta maneira o desejo me envolveu o coração nem quando te raptei da agradável Lacedemônia e naveguei as naus preparadas para o alto mar unindo-me a ti em leito de amor numa ilha rochosa da maneira como agora te amo e me domina o doce desejo.
}

Schmitz nota que as traduções contemporâneas, como é o caso, encobrem as palavras do original. Disse o tradutor: "o desejo me envolveu o coração",

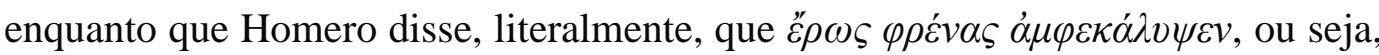
que Eros obscureceu, ou obnubilou, a sua phrén - seu torso, suas entranhas, ou a área do seu diafragma. Segundo Schmitz, phrén era o órgão físico e corpóreo das emoções, bem ao centro do corpo. Os antigos sentiriam na phrén as ocorrências de apreensão, perigo, ansiedade, temor, medo, ou, em alguns casos, mesmo de pensamento ou reflexão. Não se trataria, no caso, de um enfraquecimento da mente ou dos sentidos, mas da incidência de um sentimento no âmago do corpo. O último verso citado merece também alguma reflexão. Na tradução, as palavras "me domina 


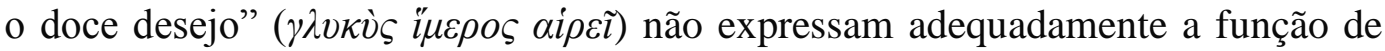
Eros. O deus não era percebido como algo de interno, como um ímpeto ou uma urgência interior que precisava de externalização, mas sim, segundo Schmitz, de uma força em derredor, de algo que pairasse e, com intencionalidade, ocasionalmente agisse sobre as pessoas. Páris portanto não cede a um clamor interno, mas é capturado externamente pelos encantos de Helena ou pelo poder de Eros - algo portanto físico e corpóreo, ainda que sutil, e algo que talvez pudéssemos chamar, anacronicamente, de uma força "substancial". Seu efeito seria o de produzir uma espécie de desequilíbrio no próprio corpo do herói. O mesmo se daria, aliás, na já mencionada cena em que Aquiles é tomado de cólera por Agamêmnon. Diz a tradução: "Enquanto isto pensava no espírito e no coração, tirando a espada da bainha, chegou Atena, vinda do céu" (Canto I, versos 193-195, na tradução de Frederico Lourenço). Schmitz alega que esse "pensava” em questão é um fenômeno físico, corpóreo, e o próprio Homero deixa claro o fato de que ele envolve a phrén - o diafragma ou as entranhas.

Os primórdios daquilo que pode ser chamado de "introjeção" dos sentimentos - a transformação de uma interioridade corpórea em uma interioridade espiritual - já pode ser antevista na própria Odisseia, mas se desenvolve aos poucos, de acordo com a mesma evolução apontada por Bruno Snell, passando pela poesia lírica para chegar até a tragédia e à elaboração filosófica que culmina em Platão. Schmitz aponta três fases consecutivas do desenvolvimento do dualismo almacorpo. A primeira envolveria a obra de Arquíloco, que ainda não reconhece a introjeção e nem tampouco o dualismo psico-somático. A segunda teria expressão nos versos de Píndaro, que ainda não parece trabalhar com a noção de emoções internas, mas já se vale do dualismo entre psyché e soma. Por fim, e como não poderia deixar de ser, a terceira fase se perfaz na obra de Platão, onde já encontramos plenamente não apenas a expressão, mas mesmo a elaboração teórica das bases tanto da introjeção quanto do dualismo.

Ao fim do capítulo, Schmitz ainda tece algumas considerações a respeito das razões ou motivações que gradualmente levaram ao processo de introjeção das emoções. Segundo ele, trata-se de um desejo ou de um impulso de emancipação. Ele diz que é natural para os seres humanos o anseio de ter controle sobre si mesmos, em vez de se conceberem como uma massa inerme à mercê de forças ou 
de impulsos divinos, daimônicos ou naturais. O "ego" tenta gradualmente não ver a si próprio como um prisioneiro de sentimentos ou de pulsões orgânicas. O processo é lento e gradual, uma vez que a concepção anterior, homérica, teria raízes antigas e partiria de uma percepção bastante espontânea - a de "ser movido" por impulsos e frêmitos sobre os quais temos pouco ou nenhum controle. Seja como for, seu texto mostra como só na obra de Platão o processo de emancipação do "eu" se completa, ao conceber uma alma que na verdade é mais forte e mais autônoma que o corpo, e que mesmo sobrevive à sua morte, retendo em si mesma algo da sua autonomia.

Também Dodds, em sua obra clássica Os gregos e o irracional $^{106}$, faz-se tributário das teses de $A$ descoberta do espírito e explora a ideia de uma concepção do ser humano, nos tempos homéricos, que ignorasse a noção de uma individualidade autônoma e plenamente responsável por si e por suas ações. No primeiro capítulo do livro, “A apologia de Agamêmnon”, Dodds lista uma coleção de casos na Ilíada e na Odisseia em que os atos mais decisivos dos personagens são atribuídos a uma intervenção divina, exterior, e não a um processo de deliberação ou decisão. O autor faz questão de esclarecer que esse pode parecer ao leitor contemporâneo um artifício psicológico com os quais os heróis tentariam se isentar de culpas ou de responsabilidades, especialmente no caso de ações recrimináveis, mas logo adverte que esse subterfúgio nem sequer faria sentido na cultura grega dos tempos homéricos. Antes de mais nada, porque "a justiça grega dos primórdios não se interessava em nada pelas intenções - era o ato que importava" ${ }^{\text {"107 }}$. Então, de fato, Agamêmnon, ao falar sobre a óx $\tau \eta$ que o levou a roubar Briseida de Aquiles para compensar a si próprio pela perda de sua concubina, afirma (Canto XIX, versos 86 ss., na tradução de Frederico Lourenço):

Só que não sou eu o culpado, / mas Zeus e a Moira e a Erínia que na escuridão caminha: / eles que na assembleia me lançaram no espírito a Obnubilação / selvagem, no dia em que eu próprio tirei o prêmio a Aquiles. / Mas que poderia eu ter feito? É o deus que tudo leva a seu termo. / E a Obnubilação é a filha mais velha de Zeus, que a todos obnubila, mortífera!

${ }^{106}$ DODDS, E. R. Os gregos e o irracional. SP: Escuta, 2002.

${ }^{107}$ Op. cit., p. 11. 
E, no entanto, o mesmo Agamêmnon nem sequer tenta se isentar das consequências de seus atos, e mansamente reconhece que tais consequências devem mesmo ter de recair sobre ele (Canto XIX, versos 137-8, mesma tradução):

Mas visto que fiquei obnubilado e Zeus me tirou o juízo, quero repor tudo de novo e oferecer incontável indenização.

E, o que talvez seja mais importante, a própria vítima de sua ação reconhece que assim foi:

Zeus pai, grande é a obnubilação que dás aos homens!

Nunca no coração no meu peito teria o Atrida

suscitado a raiva, nem levado a donzela, teimoso,

à minha revelia. Mas porventura quis Zeus

que a muitos Aqueus sobreviesse a morte.

Perpretador, vítima e mesmo o próprio poeta (conforme deixa claro logo na abertura do épico, ao dizer que a cólera de Aquiles "cumpriu o plano de Zeus") estão de acordo quanto a isso: o que concorreu para o desenrolar do acontecimento central de toda a narrativa não foi a ação de homens, mas a ação dos deuses.

A querela entre Agamêmnon e Aquiles é de especial importância para o desenrolar da trama, por razões óbvias, mas não constitui de forma alguma uma exceção ao tratar das motivações e da mola propulsora das ações humanas. Tal é o caso de Helena de Troia, que credita suas decisões e todo o seu destino ao desejo que Zeus tinha de dar aos poetas um tema para suas canções (Canto VI, versos 3567). Também Príamo reconhece (Canto III, verso 164) que não é Helena, mas sim os deuses que devem ser tidos como causa da guerra. Como há também o caso de Glauco (Canto VI, 234 e ss.), que, tendo o discernimento retirado por Zeus, fez um mau negócio e aceitou bronze como pagamento para uma armadura de ouro. Os imortais parecem ter, portanto, total ingerência não só sobre os destinos, mas também sobre os estados de ânimo, sobre as condições cognitivas e sobre as motivações humanas - algo que se manifesta nos episódios de heroísmo e de loucura, mas também no caso de pequenas decisões práticas e relativamente 
cotidianas. Conforme diz Penélope a sua ama, no Canto XXIII da Odisseia (verso 11 e ss., na tradução de Frederico Lourenço):

Querida ama, elouqueceram-te os deuses - eles que podem transtornar o juízo a quem tem excelente entendimento, e pôr no caminho da compreensão o deslassado de espírito.

Significativa aliás é a ausência, registrada por Dodds ${ }^{108}$, de qualquer léxico no grego homérico que pudesse designar o que entendemos por "decisão" ou por "ato de escolha". O autor conclui, a partir disso, que os homens dos tempos homéricos não lidavam com a noção de "arbítrio" ou de "vontade" - um conceito que se desenvolveu tardiamente na cultura grega. Seria anacrônico e incompreensível portanto para os gregos de então apresentar-lhes a questão sobre determinismo versus "livre-arbítrio" - uma elaboração que precisará aguardar por uma série de discernimentos filosóficos até ser elaborada.

Também quanto a isso Dodds propõe a análise das ocasiões em que um herói é acometido por um $\mu$ ćvos - que poderíamos traduzir como um "ímpeto", um "ardor", um "impulso" ou uma "paixão" de origem divina. Quando isso acontece, o herói está ciente de ser tomado por um misterioso acesso de energia, confiança e vitalidade. É comum aliás que ser possuído por $\mu \varepsilon ́ v o \varsigma$ aconteça aos heróis depois de uma prece ou de uma invocação, muito embora os deuses possam enviá-lo sem solicitação e aviso, e o enviem até mesmo a grupos de animais - na Iliáda, Canto XXIII, versos 468 ss., são os cavalos de Aquiles que recebem o ímpeto divino. Os homens que o recebem logo percebem o que se passa, a partir de uma sensação peculiar nos próprios membros - uma sensação corpórea, portanto. No Canto XIII (versos 59-75), o poeta diz que o deus Possêidon tocou os Ajantes com seu cetro de maneira a conferir-lhes o $\mu \varepsilon ́ v o \varsigma$, e Ájax, filho de Oileu, diz senti-lo presente em seu peito e vibrando em seus membros: “ávidos estão meus pés abaixo e minhas mãos em cima."

Mais significativo ainda, Dodds afirma que "o traço mais característico da Odisseia"109 é o fato de que os personagens atribuem toda sorte de fato mental à intervenção de um dáimon - o que, nesse contexto, significaria simplesmente "um

\footnotetext{
108 Op. cit., p. 28 , nota 31.
}

${ }^{109}$ Op. cit., p. 19. 
deus indeterminado". A coragem, o discernimento ou a falta dele, uma crise de nervos, um acesso de ansiedade - tudo isso seria o reflexo da ação de uma vaga entidade espiritual. Assim é quando um personagem é tomado de uma premonição (ou "advertência"), ou quando tem uma ideia particularmente inteligente ou estulta, ou quando reconhece uma determinada pessoa, ou quando se dá conta repentinamente do significado de uma profecia, quando se lembra ou se esquece de algo importante - ou mesmo a decisão de sair na noite fria sem levar o manto. Dodds vê nesse modo banalizado e constante de falar um reflexo "realista" da maneira como as pessoas se expressavam naquele ambiente cultural - o que evidentemente seria a manifestação de uma maneira de conceber o mundo e a presença humana dentro dele. Seria uma experiência comum a todas as pessoas a de se haver com a chegada repentina de uma ideia, de uma intuição, de um temor ou de uma apreensão, assim como a abrupta percepção de algum aspecto da realidade - ocasiões em que seria razoável, diz ele, conceber esses eventos como a incidência de algum fator exterior, como algo vindo de fora e recebido como dádiva ou como maldição. Numa comparação que talvez esclareça as coisas, o autor diz que os estados de espírito e as experiências mentais dos personagens são como uma "mudança climática", sobre a qual eles não têm ingerência e que apenas se abatem sobre eles - num processo referido com frequência pelo uso recorrente da expressão

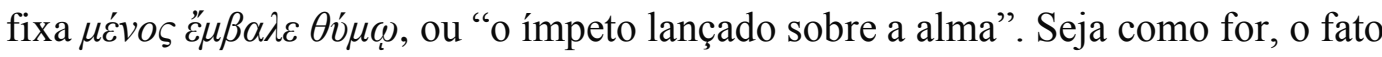
é que, tomando todos os estados mentais como assaltos lançados sobre quem os experimenta, restaria pouco espaço, se algum, para conceber os humanos como dotados de uma dimensão de interioridade - especialmente de uma interioridade altiva e capaz de ser plenamente responsável pelas suas ações.

Para encerrar as presentes considerações, é preciso ainda apenas observar que, segundo Snell (nisso aparentemente seguido por Schmitz, mas não necessariamente por Dodds), o advento da individualidade - esse processo de transformação da maneira como os seres humanos experimentam o mundo e a si próprios - não é o processo de uma instauração, ou o estabelecimento de uma possibilidade de experiência humana entre outras, ou um arranjo cultural que possa ser equiparado aos demais. Para ele, trata-se da descoberta, conforme aponta o título, de uma dimensão da experiência humana, ou da conquista de uma potência 
até então latente da nossa condição. A noção de "descoberta", no entanto, precisa ser devidamente compreendida. Diz ele, na introdução da obra ${ }^{110}$ :

Quando falamos em "descoberta do espírito", a expressão tem um valor diferente de quando dizemos, por exemplo, que Colombo "descobriu" a América: a América existia mesmo antes de sua descoberta; o espírito europeu, ao contrário, assumiu existência no momento em que foi descoberto. Ele só existe quando se torna consciente no homem. E no entanto, não está errado falarmos aqui em "descoberta". O espírito não é "inventado" da maneira que um homem inventa um instrumento apto a melhorar o rendimento de seus órgãos físicos, ou um método para o estudo de determinados problemas. Não é coisa que possa ser arbitrariamente pensada e que se possa construir adaptando-se ao objetivo, como na descoberta, nem está geralmente dirigida, como a descoberta, para um determinado objetivo: em certo sentido, existia mesmo antes de ser descoberta, mas é de forma diferente, não "como" espírito.

Esse traço algo valorativo, em si mesmo dispensável na análise que propõe, talvez seja o ponto de sua obra que possa ser considerado o mais "datado", e que a leva a ser rejeitada por parte significativa da filologia contemporânea - por reputála talvez etnocêntrica ou eurocêntrica, na medida em que toma a noção ocidental de indivíduo como uma espécie de "gabarito" da experiência humana, portanto superior às demais. Não seria aqui o lugar nem a ocasião de debater essa questão específica, porque tudo o que nos interessa da análise de Snell é a descrição desse processo de coagulação da individualidade humana, tal como passaram a entendêla os gregos posteriores, e da dimensão de interioridade de que se faz acompanhar. Essa descrição não precisa de forma alguma se comprometer com a valoração implícita que a obra propõe, e nem tampouco com a tese da "descoberta" do espírito humano, em lugar de uma "instauração" entre outras possíveis.

\footnotetext{
${ }^{110}$ SNELL, op. cit., p. VXIII.
} 


\subsubsection{A. A. Long: Encontrar a si próprio, o que fazer consigo}

Os trabalhos de Snell, Schmitz e Dodds são de grande importância e influência, mas se concentram em uma mesma questão: em que medida o ser humano vê a si mesmo como uma unidade autônoma, que tem controle e ingerência sobre si. Há outras abordagens possíveis para o processo de formação da individualidade, talvez mais próximas da filosofia do que da filologia, ao menos na medida em que leem e interpretam textos dos próprios filósofos sobre esse assunto. Dentre eles, uma abordagem que se mostra particularmente interessante é a do helenista inglês A. A. Long, que passamos a expor a seguir.

Em dois textos seminais, A. A. Long trata direta ou indiretamente do tema que nos concerne aqui, e acrescenta algumas observações que não contradizem, mas complementam as teses de Snell, Schmitz e Dodds. São eles: "Finding yourself in Greek Philosophy"111 e "Ancient Philosophy's Hardest Question: What to Make of Oneself?"112. No primeiro, o helenista defende a tese de que a maneira como os filósofos gregos passaram a investigar a phusis terminou por reconfigurar a maneira como o indivíduo humano se compreendia a si próprio, na medida em que se transformou a concepção daquilo mesmo que ele percebia como o mundo que ele integra e com o qual se relaciona. Com isso, argumenta Long, os gregos terminaram por encontrar uma dimensão maior e mais profunda para a própria individualidade humana, que se tornou então algo a ser investigado, perscrutado, e mesmo julgado. No segundo texto, ele pretende demonstrar que a própria ideia de refletir sobre os modelos de vida a serem escolhidos e adotados é um produto do pensamento filosófico, e acaba por se tornar uma das principais - se não a principal - questão da filosofia grega. Procederemos a uma exposição resumida dessas teses, para que ambas possam ser diretamente relacionadas ao conteúdo da Carta VII.

Em "Finding Finding yourself in Greek Philosophy", A. A. Long defende a ideia de que a maneira como os indivíduos compreendem a si mesmos sofreu uma profunda transformação com o advento do pensamento jônio e suas investigações em torno da phusis. Eis como ele próprio resume a hipótese ${ }^{113}$ : "Defenderei que os

\footnotetext{
${ }^{111}$ LONG, A. A. "Finding ondeself in Greek Philosophy", in Tijdschrift voor Filosofie, Nr. 2, junho de 1992.

${ }_{112}$ LONG, A. A. "Ancient Philosophy's Hardest Question: What to Make of Oneself?", in Representations, No. 74. University of California Press, 2001.

${ }^{113}$ Op. cit, p. 356.
} 
gregos, no início da filosofia ocidental, ativaram todo um aspecto do self que antes em grande medida havia permanecido latente: eles descobriram uma dimensão mais profunda do modo humano de ser."

Para sustentar essa ideia, o helenista toma como referência uma distinção proposta por Thomas Nagel na obra The view from nowhere: a distinção entre o que seria um "eu subjetivo" e um "eu objetivo". Eis, de maneira muito resumida, a tese do filósofo americano. Modernamente, estamos acostumados a pensar a consciência humana não apenas como individual mas, mais do que isso, como um fenômeno privado e mesmo idiossincrático. Ainda assombrados pelo espectro do demônio de Descartes, percebemos uma distinção em sentido forte entre uma "realidade exterior" e uma "realidade interior". Ainda que duas mentes humanas partilhem um mesmo conteúdo cognitivo, entendemo-las como sendo duas consciências distintas experimentando uma mesma percepção - como duas taças que contenham o mesmo vinho. A partir dessa perspectiva e desse modo de equacionar a experiência humana, põe-se o problema: como seria possível transcender a perspectiva individual e ter acesso ao conteúdo de uma outra perspectiva? Como saber se um conteúdo cognitivo é efetivamente partilhado por uma outra consciência humana? A questão é explicar como um self individual pode ver o mundo desde uma perspectiva que seja genuinamente sua mas não exclusivamente sua. Será o "eu pensante” humano capaz de ser ao mesmo tempo objetivo e subjetivo?

Nagel propõe que o que caracteriza efetivamente a cognição humana é precisamente isso: o fato de ela ter a capacidade, ao menos potencial, de transcender pontos de vista condicionados pessoal ou socialmente. O que nos une ao mundo físico ou natural da ciência, diz ele, é a nossa capacidade de ter um self objetivo acrescido à nossa individualidade corriqueira. O que Nagel pretende é superar o problema legado por Descartes, e que tão profundos marcos deixou na cultura e no senso comum moderno, e com isso superar o hiato entre a instância física, externa, e a instância mental, interna. O “eu objetivo", ou "eu superior" - conforme também o chama Thomas Nagel - é aquele que tenta compreender o mundo como algo que o contém, e que contém a sua própria consciência, tanto quanto todo o resto. E, como essa é uma potência de todos os indivíduos humanos, ela pode servir como a base de uma compreensão de mundo que se pretenda universalista ou inter- 
subjetiva. Importante apenas ressaltar que Nagel não sugere que essa objetividade jamais possa ser consumada plenamente. Trata-se antes de uma tendência de pensamento que pende para uma determinada possibilidade cognitiva, ou um ideal normativo, que não chega a alcançá-la plenamente. Trata-se de uma aproximação da "visão de lugar algum" aludida no título da obra - ou seja, de uma visão menos comprometida com a perspectiva individual. Trata-se do exercício de, na medida do possível, observar o próprio "eu pensante" como um fato, como um elemento constitutivo do mundo, e de observar também as suas relações com o próprio mundo e seus demais elementos. Isso nos permitiria, segundo Nagel, ultrapassar as meras aparências da realidade - em que a noção de "aparência" é identificada com aquilo que se manifesta a uma perspectiva comprometida. Segundo o filósofo, a "concepção auto-transcendente", característica do "eu superior", “deveria idealmente dar conta de quatro coisas: 1 . o que o mundo é; 2 . o que nós somos; 3 . por que o mundo aparece para seres como nós sob certos aspectos como é e sob certos aspectos como não é; e 4. como seres como nós podem chegar a uma tal concepção. ${ }^{114 \text {, }}$

A proposta de Nagel é certamente passível de críticas, e envolve noções problemáticas e talvez um tanto ingênuas, já que pretende superar o abismo surgido entre res cogitans e res extensa justamente a partir das noções, elas próprias comprometidas, de objetividade e subjetividade. Ainda assim, A. A. Long, reconhecendo essas questões e limites, pretende enxergar, na filosofia dos primeiros jônios e na tradição a que deram ensejo, o surgimento de uma nova possibilidade cognitiva que abriu espaço para a instauração de algo que se assemelha ao que Nagel chama de "eu objetivo". A análise, é claro, muda inteiramente de contexto. Já não se trata de superar um vício filosófico pós-cartesiano, já não se trata de incidir sobre um debate eminentemente contemporâneo, mas se trata, isso sim, de circunscrever uma reconfiguração cognitiva trazida pela maneira nova como o pensamento sobre a phusis se apresentou nas colônias orientais da Grécia no século VI a.C.

Na cultura helênica pré-filosófica, diz Long, o que os indivíduos entendiam de si próprios era determinado, antes de mais nada, por fatos publicamente

${ }^{114}$ NAGEL, T. The view from nowhere. Oxford: Oxford University Press, 1989., p. 74. 
observáveis. Para ilustrar a ideia, ele toma o exemplo de Aquiles: ele se consideraria o principal dos guerreiros aqueus porque os outros o viam assim, os outros o diziam, e por conta das suas façanhas em campo de batalha. Um herói homérico jamais se perturbaria com pensamentos sobre o seu lugar no mundo, sobre sua verdadeira e profunda identidade, ou algo que o valha - mas se perturbaria com frequência com a exigência de viver à altura das expectativas que os demais tinham dele. É claro que a sua visão de mundo poderia ser considerada algo objetiva, no sentido de que ela era partilhada com os demais gregos - a condição de vida dos mortais, a superioridade dos deuses, certos valores da cultura grega, e assim por diante. Mas não eram ainda "eus objetivos", no sentido que Nagel dá a essa noção. Eles não tinham nenhum interesse em se perguntar como seria o mundo desde uma perspectiva que não aquela que eles próprios experimentavam. A própria religião tradicional grega via o mundo como a expressão de um conjunto de volições individuais - atos voluntários e mesmo apaixonados dos deuses, que ganham a forma de ventanias, terremotos, tempestades etc. Todo o cosmos era concebido e conceitualizado em termos estritamente pessoais.

Os filósofos milesianos, ao contrário, passaram a descrever o mundo como composto por forças ou elementos impessoais. Se é verdade que o aér de Anaxímenes, comumente traduzido modernamente como "ar", assim como o ápeiron de Anaximandro, são princípios vivos e de caráter divino, é também certo que a intencionalidade que manifestam é de um tipo bastante distinto do da paixão dos deuses gregos. Esses elementos seriam princípios de inteligibilidade do cosmos, na medida em que os processos que regem seriam constantes e ordenados, e não impulsos passionais ou o resultado de veleidades repentinas. Desvendar as constâncias e regularidades por traz desses processos seria, em alguma medida, ver o mundo desde um ponto de vista divino. Embora não tenhamos notícia de que Anaxímenes ou os demais pioneiros jônios tenham voltado seu olhar filosófico para as questões da interioridade humana, resta evidente, diz Long, que a maneira como conceberam o mundo transfigurou o lugar e o estatuto do indivíduo pensante diante da natureza.

O que quer que no entanto possa ser encontrado de implícito quanto a isso entre os milesianos já se faz plenamente manifesto nos fragmentos de Heráclito - o 
efésio teria já alcançado plenamente, para Long, a propalada "concepção autotranscendente". E, de fato, se analisarmos os quatro pontos arrolados mais acima e que, segundo Nagel, devem ser explicados por essa concepção, veremos que a todas elas se reportam, em algum momento, o conjunto de 131 fragmentos que chegaram até nós. Em certa medida, é possível dizer que Heráclito estabelece dois patamares de conhecimento possível - um, dos mortais "surdos" (frag. 34) ou "adormecidos" (frag. 1), que enxergam e levam a sério as oposições e contradições da physis; outro, que percebe, por trás dessa "guerra" (frags. 53 e 80) ou desses "divergentes" (frag. 8, $\delta l \alpha \varphi \varepsilon \rho o ́ v \tau \omega \varsigma$ ), o próprio lógos (frags. 1 e 50), que é o princípio ordenador por detrás dos processos cósmicos. Perceber a existência desse lógos é intuir a coincidentia oppositorum, a harmonia dos contrários (frags. 8 e 51), e mesmo a unidade de fundo do universo múltiplo (frag. 50). Ou seja: Heráclito proporia a passagem de uma maneira vulgar, humana ou parcial de conceber o mundo para uma maneira algo divina - de um deus que certamente não é o Zeus olímpico, mas antes o princípio ordenador da realidade. Heráclito teria o intuito de almejar a "perspectiva de lugar algum". Em outras palavras: o efésio tenta descrever um cosmos regido por processos impessoais desde um ponto de vista também ele impessoal. Quanto a isso, é significativo que, no famoso fragmento 50, ele peça que o leitor ouça não a Heráclito, mas ao próprio lógos. É precisamente esse o ponto de Nagel: a capacidade humana de conceber o mundo desde uma perspectiva distanciada de si próprio, e incluir o seu próprio self subjetivo como um dos elementos que constituem esse mundo. Essa maneira de experimentar a realidade leva o cognoscente a ver a si próprio como mais uma coisa entre todas as outras, e não como um centro especial de atenção.

Sintomaticamente, é também de Heráclito a mais antiga notícia de que dispomos de um filósofo que tematizasse, ainda que de maneira críptica e extremamente lacônica, a si próprio como uma questão a ser investigada. Diz ele no fragmento 106: "Busco a mim mesmo". Na frase, o sujeito cognoscente e o algo a ser conhecido são um e o mesmo (o objeto é o pronome reflexivo na primeira

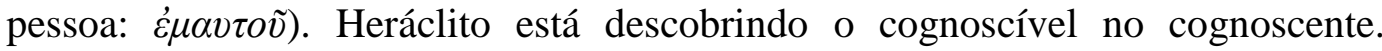
Embora não fale explicitamente em "auto-trascendência", é evidente que há aí alguma coisa que assim poderia ser chamada. E, no fragmento 96, uma importante passagem já mencionada (trad. Alexandre da Costa): "Não encontrarias os limites 
da alma, mesmo todo o caminho percorrendo, tão profundo lógos possui." Não é aqui o lugar para discutir o sentido desse fragmento, e nem mesmo o de chamar atenção para o fato de que, ao que tudo indica, o mesmo lógos que ordena o cosmos está também presente na psuché humana. Vamos nos ater a chamar atenção para a

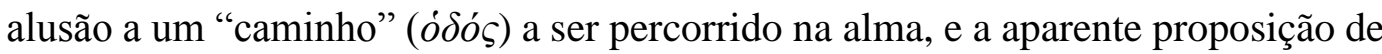
que essa mesma alma não se contenha por nenhum limite.

Esse exercício cognitivo de si próprio talvez pudesse ser chamado de introspecção - mas certamente não no sentido que modernamente damos a esse termo, ou seja, um escrutínio de estados individuais de consciência, ou a sucessão de disposições, sentimentos e paixões privadas. Mas se, conforme é dito no fragmento 112, a sophrosune consiste em "perceber as coisas conforme a sua natureza", e isso se relaciona diretamente com o fragmento 50 (“Ouvindo não a mim, mas ao lógos"), resta por fim evidente que Heráclito propõe uma íntima relação entre conhecer-se a si próprio e conhecer o mundo. Seja como for, A. A. Long chega a afirmar, peremptoriamente, que ${ }^{115}$ "pode-se conceber toda a sua filosofia como uma resposta à máxima délfica 'Conhece-te a ti mesmo'.”

Conforme já dito, não foi essa a única ocasião em que A. A. Long defendeu que o advento da filosofia trouxe uma transfiguração da noção do "eu" individual. No texto "Ancient philosophy's hardest question: what to make of oneself?", o helenista inglês apresenta considerações que se relacionam ainda mais intimamente com o tema que estamos perseguindo no presente estudo. Procederemos a uma sucinta exposição crítica das ideias aí defendidas.

O título do texto é propositalmente ambíguo: em inglês, "What to make of oneself?" significa ao mesmo tempo "o que fazer de si mesmo?" e "como dar conta" ou “como explicar a si mesmo?”. Ou seja: há aí uma dimensão prática e ao mesmo tempo cognitiva, e a ambiguidade calculada do título pretende se reportar à dupla natureza que essa questão adquiriu no pensamento filosófico grego. Os filósofos antigos estavam preocupados, ao mesmo tempo, em compreender ontologicamente o estatuto do indivíduo humano, e também em investigar e discernir qual seria a "boa vida a ser vivida". A rigor, é claro as duas questões se relacionam de maneira

${ }^{115}$ LONG, op. cit., p. 272. 
muito natural, já que conceber o que seja o indivíduo humano já comporta, em certa medida, indicar como ele deve viver a própria vida - e vice-versa. E na verdade, assim entendido, não é demasiada ousadia dizer que todos os arranjos culturais parecem trazer implícita, nos próprios modos de vida que forjam, uma relação com essas duas questões - frequentemente levantadas e tematizadas pelas narrativas míticas, pelas ancestrais histórias que fornecem modelos positivos e negativos de conduta, assim como sistemas de interdição e prescrição, ideiais de vida a serem seguidos etc. O que nos concerne aqui, e o que concerne especificamente ao exercício autobiográfico que constitui a Carta VII, é a maneira como essa questão foi apropriada pela filosofia, e como se tornou o tema de uma investigação dialética.

Seria um equívoco, diz Long, afirmar que os primeiros filósofos da tradição jônia eram indiferentes a essas questões. Seja como for, ainda que desconsideremos especulações cabíveis sobre Tales, Anaximandro e Anaxímenes, naquilo que nos resta como doxografia de Xonófanes e Heráclito já se nota de maneira mais clara a tematização do problema "o que é o Homem" (ou “o que sou eu”) e "como deve ele (ou devo eu) viver". Ou seja: uma ética e uma antropologia filosófica. ${ }^{116}$

Conforme acontece com tantas outras questões, Platão dela se apropria, faz dela o foco central de algumas extensas especulações, e acaba por transfigurá-la e reequacioná-la inteiramente. No Fedro, depois de afirmar a prioridade da questão "conhece-te a ti mesmo" sobre quaisquer outras especulações sobre o mundo ou sobre as antigas narrativas (229e-230a, trad. Carlos Alberto Nunes: "até agora não fui capaz de conhecer-me a mim mesmo, conforme aquilo do Oráculo de Delfos, donde parecer-me ridículo estudar coisas estranhas antes de saber quem eu sou" e "Como disse há pouco, em lugar de investigar essas coisas, cuido apenas de examinar-me"), Sócrates insinua ser um híbrido ou uma tensão entre dois pólos: um monstruoso e um divino: "Quero saber se sou algum monstro mais complexo e cheio de fumo do que Tífon, ou algum ser delicado e simples, que, por natureza, participe de um destino de algum modo divino e sem fumos de qualquer espécie." $(230 a)^{117}$. Vê-se que a questão posta não é a do lugar de um polítes diante da cidadeestado, mas sim a do próprio estatuto ontológico de si mesmo: o uso da expressão

\footnotetext{
${ }^{117}$ Voltaremos a esse mesmo trecho mais adiante para elucidar certas questões sobre o texto autobiográfico da Carta VII.
} 
"por natureza" ( $\varphi v ́ \sigma \varepsilon l$, no dativo) demarca o caráter da discussão. A especulação socrática vai se desenvolver na direção de afirmar, como em tantos outros pontos na obra platônica, que o ideal de vida humano é o de tornar-se o mais possível semelhante ao dos deuses, ou "viver divinamente" (o mesmo preceito apresentado em Teeteto 176a, Timeu 90b-d, República 613a). É evidente que esse ideal de vida precisa ser muito bem compreendido, assim como a expressão "divinamente", já que várias possibilidades de ruído se insinuam ao intérprete contemporâneo.

Seja como for, já é imensamente significativo o próprio fato de a identidade humana e da questão da melhor vida a ser vivida estar sendo apresentada como uma questão filosófica. Temos todas as razões para crer que, em contexto pré-filosófico, a identidade humana era um dado, algo já resolvido pelos dispositivos estabelecidos da cultura. A vida a ser vivida era também algo que era dado de maneira razoavelmente instintiva, em grande medida determinada pela linhagem e pelas condições externas mais imediatas, sem que talvez jamais se pusesse a questão “qual das vidas possíveis devo viver?” É bem verdade que algo como o prenúncio dessa questão pode ser vislumbrado no episódio da escolha de Aquiles, apresentado pelo próprio no Canto IX da epopeia, v. 410ss (aqui na tradução de Frederico Lourenço):

\begin{abstract}
Na verdade me disse minha mãe, Tétis dos pés prateados, que um dual destino me leva até ao termo da morte; se eu aqui ficar a combater em torno da cidade de Tróia, perece o meu regresso, mas terei um renome imorredouro; porém se eu regressar a casa, para a amada terra pátria, perece o meu renome glorioso, mas terei uma vida longa, e o termo da morte não virá depressa ao meu encontro.
\end{abstract}

Faremos aqui no entanto algumas breves observações a esse respeito. Em primeiro lugar, essa escolha entre duas possibilidades de vida não chega a deixar a questão "quem é Aquiles?" inteiramente em aberto, e a opção que ele faz parece trazer algo de inevitável. Ela antes reforça a natureza do ímpeto vital que faz com que Aquiles seja quem é. Ademais, é de se notar o modo como o autor dos versos

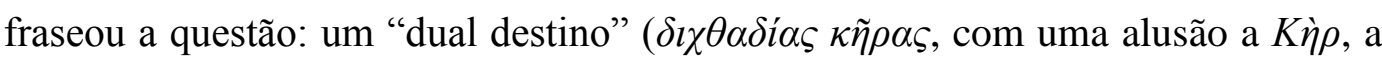
deusa da morte, mas cujo nome também designa a fatalidade, ou, em alguns casos, a ruína, a decadência inevitável) o "conduz" ( $\varphi \varepsilon \rho \varepsilon \varepsilon \mu \varepsilon v)$ até o "termo da morte" 


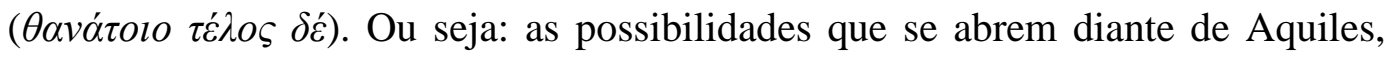
apenas duas, já foram inteiramente estabelecidas pelo destino. Se é razoável ver aí a gestação de uma futura questão filosófica a respeito da melhor vida a ser vivida, é igualmente razoável não enxergar aí mais do que justamente isso: um germe.

Em alguma medida, o pensamento filosófico se desenvolve em paralelo com essa evolução sobre o próprio estatuto da identidade humana: ela passa a ser vista como um algo em aberto, não inteiramente determinado - algo que poderia ser dito uma espécie de poiesis de si, não como opção ou possibilidade, mas como um imperativo existencial derivado da própria condição humana de vida ${ }^{118}$. Seria talvez muito difícil estabelecer com precisão se a prática do pensamento filosófico foi a causa ou se foi um produto dessa inflexão na maneira como a individualidade é concebida, e o mais prudente, nesse caso, seja apenas apontar a existência de uma correlação entre esses dois fenômenos, em que a filosofia talvez seja, dialeticamente, em parte propulsora dessa questão e em parte uma consequência dela. De toda forma, o importante a ressaltar é que essa questão - "qual a boa vida a ser vivida" - não se torna apenas um dos temas cultivados e investigados pela filosofia, mas sim uma das suas maiores e principais questões, já com lugar de destaque nas obras de Platão e Aristóteles, e com centralidade absoluta em toda a filosofia produzida no chamado "período helenístico".

\subsubsection{Cornford: a filosofia grega chega à vida adulta}

Uma visão bastante clássica sobre o desenvolvimento da filosofia grega, e em especial sobre a emergência de questões envolvendo a condição humana e as investigações sobre a psique, pode ser encontrada na obra Antes e depois de Sócrates $^{119}$, de Francis McDonald Cornford. Essa visão pode ter muito de algo que hoje pode ser considerado “datado" e problemático, não só no tipo de valoração que apresenta sobre as diversas fases da filosofia grega, mas também naquilo que se atribui a cada uma delas - e mesmo em tudo o que essa tese parece pressupor a

\footnotetext{
${ }^{118}$ O tema da "poiesis de si” será desenvolvido mais adiante neste mesmo trabalho.
}

${ }^{119}$ CORNFORD, F. F. Antes e depois de Sócrates. SP: Martins Fontes, 2005. 
respeito da relação entre a cultura grega (e seus herdeiros) e todas as demais culturas. Ainda assim, é bastante pertinente apresentar suas teses neste ponto da exposição, e isso por duas razões: em primeiro lugar, porque elas encerram uma visão muito difundida, explícita ou tacitamente, sobre o pensamento grego; em segundo lugar porque, lidas criticamente, essas teses podem trazer alguns dados interessantes para que compreendamos o contexto cultural que deu nascimento ao discurso da autobiografia filosófica.

Em uma metáfora que se tornou famosa, ainda que algo problemática, Cornford compara o desenvolvimento do pensamento grego aos estágios de maturação de um indivíduo humano: o pensamento pré-socrático, com seu maravilhamento ingênuo e assistemático diante do mundo, com sua obsessão por uma versão bastante crua da pergunta "por quê?", seria como a infância da filosofia; o movimento sofístico seria como a sua adolescência - questionamento de valores, ímpeto afirmativo, desejo de independência e liberdade, uma "crise revolucionária", uma revolta contra as figuras "paternas" (aí representadas pelas tradições e costumes), um certo niilismo desafiador diante das convenções; e, com Sócrates e a partir dele, por fim, a filosofia teria chegado à vida adulta, à plenitude, à maturidade das questões que de fato importam e que são dignas de serem pensadas por indivíduos cientes de suas responsabilidades e de seu lugar no mundo ${ }^{120}$.

A virada para a maturidade, diz o helenista, seria demarcada justamente pelo surgimento das questões éticas, e pela descoberta da vastidão da dimensão interior dos seres humanos. O advento do pensamento socrático teria promovido uma profunda mudança de rumos no próprio hábito humano de pensar, e depois dele restou a Platão e a Aristóteles não apenas dar continuidade a essas investigações sobre a psique, mas também retornar às questões ontológicas e cosmológicas de uma maneira inteiramente nova, transformada por esse novo dado. Cornford chega

\footnotetext{
${ }^{120} \mathrm{~A}$ analogia proposta por Cornford chega ao extremo de estabelecer com precisão numérica as idades a que corresponderiam as diferentes fases da cultura grega. O pensamento mítico e préfilosófico seria como a primeira infância, do nascimento aos seis anos, quando o bebê ainda tem dificuldade de distinguir seu corpo do ambiente em torno. A filosofia dos primeiros jônios corresponderia ao período dos seis aos 13 anos de idade, num misto de ingenuidade e deslumbramento de perguntas muito elementares e de respostas ingênuas. A sofística corresponderia ao período dos 14 aos 20 anos, movida pela mais crua rebeldia juvenil. E, a partir de Sócrates, o pensamento grego desfrutaria da altivez da maioridade: a partir dos 21 anos de idade. Cf. op. cit., p. 36ss.
} 
ao ponto de dizer que Sócrates promoveu a "descoberta da alma" 121 , naquilo em que é considerada acima e além da dimensão social. A Sócrates deveríamos a conquista da própria autoconsciência humana.

Significativamente, Cornford afirma que ${ }^{122}$ “A vida de Sócrates encontrou seu devido lema na inscrição délfica 'Conhece-te a ti mesmo'.”. E então propõe uma pergunta pertinente:

Por que teria o Homem, exatamente nessa época e nesse lugar, descoberto em si mesmo um problema de uma importância mais premente do que a compreensão da Natureza externa a ele? Poderíamos esperar que a filosofia começasse em casa, com a compreensão de que a própria alma humana e o significado da vida humana representam mais para o Homem do que a história natural das coisas inanimadas. Por que o homem estudou a Natureza em primeiro lugar, tendo-se esquecido da necessidade de conhecer a si mesmo até Sócrates proclamar que essa necessidade era a sua principal preocupação?

A resposta a essa questão nos leva a uma outra maneira de descrever o processo pelo qual a filosofia grega se desenvolveu. Segundo Cornford, numa explicação que se relaciona mais diretamente ao tema que estamos perseguindo aqui, um princípio descritivo seria o de apresentar o desenvolvimento da filosofia como um gradual exercício de afastamento em relação aos elementos constitutivos da experiência humana. Esse processo de afastamento, conquistado por etapas sucessivas, teria tornado os gregos aos poucos mais e mais capazes de um pensamento agudo, apto a descrever acuradamente as estruturas mesmas da realidade.

Eis como se daria esse processo de "afastamento gradual". A concepção mítica do mundo, diz ele, é aquela em que os humanos mal conseguem se apartar dar natureza, e atribuem a ela toda sorte de paixões, sentimentos e motivações análogas ou mesmo idênticas às suas próprias - o que seria, diz ele, um comovido desejo de compreender e, sobretudo, de controlar os eventos naturais ${ }^{123}$. O

\footnotetext{
${ }^{121}$ Op. cit, pp. 34 e 35.

${ }^{122}$ Op. cit, p. 6.

${ }^{123}$ Op. cit., p. 35.
} 
surgimento da filosofia teria marcado "o momento em que o Homem conseguiu apartar sua própria natureza do mundo exterior a ele" ${ }^{124}$. Isso teria implicado reconhecer que esse mundo era muito mais desconhecido, estranho e enigmático do que supunha a concepção mítica. E aconteceu que, "imerso no interesse pelo objeto, o Homem esqueceu-se de pensar em si mesmo" - afirma ele, ao se referir à pretensa (e discutível) ausência do elemento ético no pensamento pré-socrático. Dá-se então um segundo esforço de afastamento, mais consciente e mais doloroso: aquele que promove um desligamento em relação à cultura, à tradição, aos valores e aos costumes. Já anteriormente alheado em relação à phusis, o intelecto humano agora também se alheia em relação ao nomos - e cada um desses passos de distanciamento permite que aquilo de que se distanciou seja investigado, escrutinado, analisado filosoficamente. Nesse processo gradual, resta ainda o passo final, que, segundo Cornford, foi dado evidentemente por Sócrates: o distanciamento em relação a si mesmo. Também nesse caso, o ato de distanciar-se permitiu tornar a si próprio um objeto de investigação filosófica, uma ocasião de thauma e de escrutínio, e descobrir que também a própria interioridade seria um problema a ser atacado. Diz ele $^{125}$ :

\begin{abstract}
Não fora apenas o homem Sócrates, mas a própria filosofia, que se voltara, na pessoa dele, do mundo exterior para o interior. Até aquele momento, os olhos da filosofia tinham-se voltado para o exterior, em busca de uma explicação razoável do espetáculo mutante da Natureza que nos rodeia. Agora, sua visão dirigia-se para outro campo - a ordem dos objetivos da vida humana - e, no centro desse campo, para a natureza da alma individual. A filosofia pré-socrática começa (...) com a descoberta da Natureza; a filosofia socrática começa com a descoberta da alma humana.
\end{abstract}

No desenvolvimento desse processo, Cornford elege como momento privilegiado justamente o discurso autobiográfico que Sócrates apresenta no diálogo Fédon, na ocasião da sua condenação à morte. Ali, no dramático momento da sua execução, Sócrates teria apresentado uma espécie de testamento intelectual,

\footnotetext{
124 Idem.

125 Op. cit., p. 6.
} 
uma de declaração de princípios filosóficos - as razões para desencantar-se com os filósofos da natureza, o desejo de empreender um outro tipo de investigação, o surgimento das questões sobre a boa vida e sobre a ação moral etc.

Mais adiante teremos ocasião de empreender uma análise do discurso autobiográfico apresentado por Sócrates no Fédon - sua importância para a leitura da Carta VII, seu significado filosófico etc. Por enquanto, retenhamos que Cornford o aponta como momento privilegiado de mudança de patamar no estatuto da filosofia, e talvez como o momento mesmo em que, na descoberta do "si mesmo" como tema de investigação, a filosofia alcançou a maioridade.

\subsubsection{Uma síntese crítica}

Feitas essas três exposições, termos certamente uma ideia bem mais clara sobre o que se pode considerar como o processo gradual da formação da noção de individualidade na cultura grega do período arcaico. De cada um dos estudiosos listados, podemos reter alguns pontos importantes em relação a esse processo. De Snell, Schmitz e Dodds, a própria formação da ideia de um "sujeito" agente e responsável por si, e a instauração de uma dimensão interior que seja sede das volições e decisões humanas; a formação de uma ideia unitária de "psique"; a própria interiorização das emoções e sentimentos humanos. De A. A. Long, uma nova condição do indivíduo cognoscente diante do cosmos, na medida em que tenta compreendê-lo desde a "perspectiva do lugar algum", e na medida em que se inclui a si próprio nesse exercício cognitivo; também a própria ideia de que o "si mesmo" era algo a ser investigado e compreendido, por um lado, mas também instaurado um processo de que dá testemunho o próprio surgimento da questão "o que fazer de mim mesmo?", ou “qual a melhor vida a ser vivida?" De Cornford, por fim, a ideia de que o pensamento grego se desenvolveu pelo gradativo processo de afastamento em relação aos elementos constitutivos do mundo - natureza, costumes e, por fim, o afastamento em relação a si mesmo, a ponto de fazer de si e da sua vida uma questão a ser pensada e decidida filosoficamente. 
O processo talvez seja um só e o mesmo, mas encarado e compreendido por ângulos diferentes. E é claro que esse processo tem profundos desdobramentos morais, éticos, políticos, religiosos e ontológicos. É clara a maneira como ele se relaciona com a formação da noção de polités, com o surgimento das antigas cidades-estado. É igualmente evidente as suas relações com o surgimento, na atividade artística e artesanal, de uma noção forte de "autor". Tudo isso concorre para forjar uma noção de indivíduo certamente diferente daquela que vigorava em tempos homéricos.

Lidos criticamente e devidamente digeridos, os estudos apontam para um fator que nos interessa aqui de maneira direta: em um certo sentido, o referente do pronome $\varepsilon \dot{\gamma} \gamma \omega ́$ aos poucos deixou de ser um dado e tornou-se uma questão. A própria identidade do indivíduo deixa de ser algo fornecido pronto pela cultura e torna-se algo relativamente em aberto. O indivíduo torna-se algo a ser investigado e compreendido, por um lado, mas também algo a ser escolhido e instaurado. Sem isso, não teria sido possível que o personagem Sócrates dissesse, como disse nos diálogos de Platão, que a principal tarefa filosófica dos homens é a de conhecer a si mesmo e, depois disso, optar por uma vida "divinamente vivida". Tampouco seria possível que o mesmo Platão escrevesse um texto em que expõe a própria vida como um tema de reflexão filosófica - um exercício que pode ser visto como a culminação desse processo.

Não é em absoluto uma coincidência que, concomitantemente a todo esse processo, passasse a figurar em Delfos uma máxima que impunha como imperativo a todos os mortais: "conhece-te a ti mesmo". Não é tampouco uma coincidência que essa máxima fosse apropriada pela filosofia de Platão como uma questão profunda e da maior dignidade - e que impõe-se como presença marcante no texto da Carta VII. É esse o tema da próxima seção.

\section{3. "Conhece-te a ti mesmo"}

Existe alguma controvérsia sobre de que maneira o imperativo $\gamma \nu \tilde{\omega} \theta l$

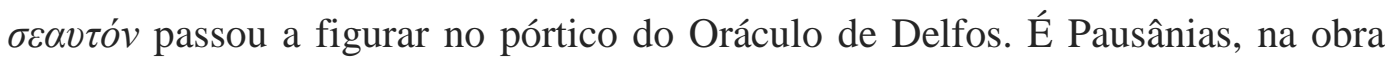


Descrição da Grécia (10.24.1), quem nos dá as primeiras notícias a esse respeito. Diz ele que alguns homens "que os gregos consideravam sábios" (e que depois passariam à História, em listagens diferentes, como "os sete sábios da Grécia") foram até o templo e dedicaram a Apolo algumas máximas para o proveito dos demais cidadãos ${ }^{126}$ :

No vestíbulo (prónaos) estão transcritas, para orientação das pessoas, máximas filosóficas que provinham de homens que os gregos consideravam sábios. Foram eles: Tales de Mileto, Bias de Priene, Pítaco de Mitilene (na ilha de Lesbos), Cleóbulo de Lindos (na ilha de Rodes), Sólon de Atenas, Quílon de Esparta e, como sétimo, é citado por Platão, em lugar de Periandro de Corinto, Míson de Queneia, uma aldeia perto do monte Eta. Esses homens vieram então a Delfos e dedicaram a Apolo as famosas sentenças - "conhece-te a ti mesmo" e "nada em excesso" - que foram aqui registradas.

É no entanto necessário registrar que essa mesma frase sobre o autoconhecimento já figurava no pórtico de outro famoso templo da Antiguidade: o templo de Luxor, no Antigo Egito. Conta-se que esse templo se dividia em duas partes: o Templo Externo, aberto à visitação pública, e o Templo Interno, reservado a pessoas iniciadas em certas cerimônias, e portanto dignas de ter acesso a elementos religiosos e conhecimentos mais elevados. Era no Templo Externo que se liam as máximas "O corpo é a casa do deus", e, em seguida, "Homem, conhece a ti mesmo". No Templo Interno, a frase era completada: "Homem, conhece a ti mesmo, e assim chegarás a conhecer os deuses."127

São inúmeros os relatos segundo os quais as figuras de maior proeminência da sabedoria grega empreenderam viagens pelo Egito. Lendárias ou não, essas notícias biográficas parecem registrar uma certa tendência dos sábios e dos primeiros filósofos de buscar em outras civilizações, em especial a egípcia, elementos que pudessem integrar em seu corpo de saberes - de maneira que não é inverossímil que de fato a frase de Delfos tenha uma inspiração egípcia, ainda que

\footnotetext{
${ }^{126}$ Apud. MARION, G. O oráculo de Delfos. SP: Odysseus, 2013. p. 49. A tradução do trecho, indireta, é de Evaristo Pereira Goulart.

${ }^{127}$ SCHWALLER, I. Her-Bak: The Living Face of Ancient Egypt. London: Hodder and Staughton, 1954.
} 
em um sentido diferente, apropriativo e marcadamente helênico. Fato é que a máxima se tornou célebre e terminou consagrada como uma das referências de instrução de vida na cultura e nos valores gregos. Diferentes autores do próprio mundo antigo a atribuíram a sábios diversos: Platão, no Protágoras, a atribui à sua lista de sete sábios (343a-343b); Diógenes Laércio a atribui a Tales (I.40), e adverte que Antístenes a atribuiu ao poeta mítico Femonoe, e que foi depois apropriada por Quílon; o poeta romano Juvenal chega a afirmar que a máxima desceu diretamente dos céus (Satires, 11.27). Tudo somado, seria virtualmente impossível encontrar para ela uma autoria individual, e assim o afirmam os estudiosos modernos, como H. Parke e D. Wormell ${ }^{128}$ : "A verdadeira autoria das três máximas exibidas no templo délfico deve permanecer incerta. Elas eram provavelmente provérbios populares, que posteriormente foram atribuídas a sábios específicos.”

Tais questões não são ociosas. O templo de Delfos era considerado o mais importante e influente templo de toda a Hélade ${ }^{129}$ - mais do que o oráculo de Zeus em Dodona, mais do que o famoso Artemision de Éfeso, mais do que qualquer templo de Esparta ou de Atenas. Além de simplesmente importante na hierarquia dos locais religiosos ou sagrados, Delfos era considerado o "centro do mundo" - o "ônfalos", ou o umbigo da Terra. Dizia um mito que Zeus tinha o desejo de determinar o ponto médio do mundo, e para isso fez com que duas águias, partindo das bordas extremas do disco terrestre, no Oriente e no Ocidente, voassem uma ao encontro da outra. O lugar em que se encontraram foi demarcado com uma pedra em formato ovoide - pedra que jazia no interior do templo e era chamada, ela própria, de "ônfalos". Além dela, havia ainda em Delfos uma outra pedra, tida como nada menos do que aquela que o deus Cronos regurgitou, junto com os deuses olímpicos, logo antes da Titanomaquia - conforme Hesíodo relata na Teogonia, versos 498-500. Zeus mesmo a teria posto no templo, para ensinança dos mortais. Quando, por volta de 600 a.C., Anaximandro desenhou um mapa de todo o mundo, fez o templo de Delfos figurar em seu centro.

A importância do oráculo no imaginário grego se atesta facilmente pela sua constante presença na literatura - Heródoto o cita e o faz participar em diversos

${ }^{128}$ PARKE, H. \& WOEMELL, D. The Delphic Oracle, vol. 1. Basil: Blackwell, 1956. p. 389.

${ }^{129}$ V. sobre isso, MARION, G., op. cit, esp. cap 1. 
episódios; uma tragédia inteira (o Íon de Eurípedes) e parte de outra (as Eumênides de Ésquilo) se passam no santuário; é notório o papel que desempenha na Apologia de Sócrates, ao dar a Sócrates a sua missão filosófica de vida; na República 427bc, Platão defere a Delfos a superintendência religiosa, "porque sem dúvida este deus, instalado no omphalos, no centro da terra, é o intérprete tradicional para todos os seres humanos em tais matérias" (trad. Maria Helena da Rocha Pereira); e, por fim, em Leis 828a, prescreve-se que os sacrifícios e as festividades da cidade serão estabelecidos de acordo com o oráculo. Mas mais do que sua presença na literatura e em textos filosóficos, a centralidade de Delfos na vida grega se atesta pela sua importância nas questões políticas. Ele era consultado quando uma cidade instituía uma nova constituição, ou quando planejava o estabelecimento de uma nova colônia, ou quando efetuava alguma reforma em seus cultos e datas sagradas. Durante o movimento de grandes colonizações, entre 750 e 530 a.C., quando foram estabelecidas novas cidades em lugares então considerados ermos e inóspitos, o empreendimento arriscado e perigoso só se efetivava mediante a recepção da proteção divina, a qual era conferida por Apolo através da pítia e dos profétai. O deus indicava se a empreitada era devida, e em seguida designava um "chefe" e os ritos para fundar a cidade. Só depois disso a pátria era "oficialmente" fundada. A própria Sicília, tema central das cartas de Platão, é, toda ela, o resultado de empreendimentos que foram comandados em Delfos - e por essa razão lá havia, aliás, um templo dedicado a Apolo na cidade de Naxos. Maria Helena da Rocha Pereira resume a questão ${ }^{130}$ : "[O Oráculo de Delfos] era, sob muitos aspectos, o centro da vida grega", que "exerce no mundo grego uma influência incalculável". Tudo isso nos dá a dimensão da importância de uma máxima que figurasse em seu frontispício, recebendo os peregrinos de toda a Grécia, e mesmo de fora, que percorressem vastas distâncias para ter uma audiência com o deus. De todos os imperativos e conselhos normativos da cultura grega, esse haveria de ser o de maior peso, influência e relevância culturais.

${ }^{130}$ PEREIRA, M. H. da R. Estudos de história da cultura clássica, vol 1. Lisboa: Calouste Gulbenkian, 2006. p.323. 


\subsubsection{A máxima na literatura e na filosofia}

Não é, portanto, de espantar que a frase délfica se faça presente em diversas das mais importantes obras que nos restaram da Antiguidade arcaica e clássica. Ésquilo a faz figurar na tragédia Prometeu acorrentado, quando o deus Oceano diz ao personagem-título que ele deveria conhecer-se a si mesmo em vez de insurgirse contra uma decisão do próprio Zeus. No contexto, a frase no imperativo tem o tom de aconselhar a prudência de resignar-se com a existência de um novo tirano nos céus, e de aceitar o lugar devido dentro dele (verso 309, trad. Jaa Torrano): "Conhece-te, e harmoniza com novos modos, novo é o tirano entre os Deuses.".

Ainda entre as tragédias, é digna de menção a passagem de As bacantes em que Dioniso se dirige ao mortal Penteu, quando este último manda que o deus seja acorrentado (v. 504 ss., na tradução de Eudoro de Souza):

D.: Não me prendam. Mando eu, sábio, aos que o não são.

P.: E eu, que te acorrentem. Sou o mais forte!

D.: Não sabes o que dizes, nem o que fazes, nem o que és.

P.: Meu nome é Penteu. Sou filho de Equíon e de Agave.

D.: À desdita te predestina o nome.

Embora o preceito délfico não esteja citado ipsis litteris, ele está claramente aludido. O trecho comporta certamente muitas nuances interpretativas que não são pertinentes aqui, mas algo bastante claro já salta aos olhos mesmo na mais ligeira das leituras: o rei de Tebas crê conhecer a si próprio a partir de traços circunstanciais - seu nome, sua linhagem etc. -, ao passo que ignora a fragilidade da sua condição, e mesmo a fortuna que lhe foi reservada pelo destino que trazia inscrito no próprio nome. É digo de nota que, nos poemas homéricos, há uma pergunta-padrão que é sempre apresentada aos estranhos e forasteiros: “Quem és e de onde vens?”. Essa indagação é sempre respondida da mesma maneira: o homem declara qual seja o seu nome, sua linhagem, sua pátria natal ${ }^{131}$. Essa é a resposta que Penteu dá a

${ }^{131}$ LONG, A. A. "What to make of oneself" in ?", in Representations, No. 74. University of California Press, 2001. p. 20.

${ }^{131}$ Op. cit, p. 356. 
Dioniso para redarguir a provocação: "Penteu, filho de Equíon e Agave". O recado do deus é evidente: isso não é nem de longe suficiente para dar conta da questão “quem és?”. Conhecer-se a si próprio não é algo dado, tarefa que os humanos tragam já realizada, ou simples de ser cumprida. Mais do que isso: são frequentes, quanto a isso, os episódios de autoengano, a crença de conhecer-se quando na verdade tudo se ignora a respeito de si próprio. O desfecho da tragédia, em que Penteu é literalmente dilacerado por sua mãe Agave, não apenas termina de revelar a sua real condição, como traz também uma lição a respeito do destino reservado aos mortais que se esquecem de seus limites e desafiam os deuses ${ }^{132}$.

Fora do contex to trágico ou poético, a máxima délfica foi um tema frequente na filosofia que nascia, e traços dela já podem ser encontrados em Heráclito, em Xenófanes, entre os eleatas e no pensamento dos sofistas. Mais adiante, ela passou a ser reiterada e diretamente associada à figura do Sócrates histórico, e não apenas ao personagem dos diálogos de Platão (sobre o qual falaremos mais abaixo). As duas outras grandes fontes de que dispomos para o caráter e a disposição de Sócrates - Xenofonte e Aristófanes - o associam a esse preceito. Essa apropriação socrática é a mais antiga notícia que temos de o preceito délfico ter se tornado um tema de investigação filosófica - ou seja, de algo a ser problematizado e compreendido, e não simplesmente aceito e praticado como um preceito autoevidente.

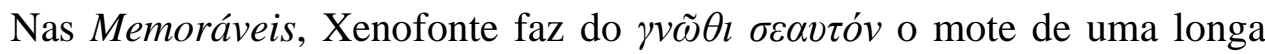
discussão filosófica entre Sócrates e o adivinho Eutidemo (4.2.24 ss.). Depois de censurar a maneira como seu interlocutor busca colecionar sabedoria através dos livros dos homens ilustres, Sócrates pergunta se Eutidemo já havia estado em Delfos, e se tinha refletido sobre a máxima do pórtico. A seguir, sugere que o homem que conhece a si próprio é como um comprador de cavalos que, antes de adquirir o animal, informa-se sobre as suas habilidades, seu pendor para a obediência ou a desobediência, sua velocidade ou lentidão, seu vigor físico ou sua fraqueza. Assim, conhecer-se a si próprio seria ter plena ciência das próprias

\footnotetext{
${ }^{132}$ Coisa semelhante talvez pudesse ser dita sobre o mito e a tragédia de Édipo, o tirano de Tebas, embora a máxima délfica não seja mencionada em nenhum momento no texto da peça. Trata-se de um herói que, evidentemente, não sabe quem é e busca sabê-lo, com todas as dolorosas consequências implicadas no processo. Não é o propósito da presente pesquisa, no entanto, promover uma análise exaustiva da questão do autoconhecimento na cultura grega, e menos ainda no gênero trágico, mas sim apenas aludir à presença da questão, com seus traços gerais, para poder lançar luz sobre o complexo de semelhanças e diferenças em relação à filosofia de Platão.
} 
habilidades e limitações, e saber portanto aquilo que se é capaz de empreender.


maneira intermediário entre o caráter prático e social que o imperativo resguardava na cultura grega anterior e o sentido de autoconhecimento anterior que adquirirá na filosofia de Platão, conforme veremos abaixo.

Sob a forma de uma caricatura, o preceito délfico também aparece em $A s$ nuvens, de Aristófanes, associado a Sócrates, seus discípulos e seu ideal de vida. Quando Estrepsíades, depois de uma visita ao Pensatório, tenta convencer seu filho a tornar-se aluno regular da "escola socrática", o rapaz protesta: "Mas, afinal, que coisa útil se poderia aprender, no meio desses indivíduos?" Ao que o pai responde (versos 840 ss., trad. Gilda Maria Reale Starzynski): “Ora, sim senhor! Toda a sabedoria que os homens têm. Você conhecerá a si mesmo, aprenderá como é ignorante e grosseiro." Se o propósito da cena é evidentemente cômico, é preciso levar em conta que ela só pode surtir esse efeito porque, presumivelmente, a máxima já era suficientemente associada a Sócrates, ao seu meio e sua proposta de filosofia - tanto quanto as falas complicadas, as investigações difíceis que chegavam a aporias, uma certa extravagância no agir etc.

É no entanto na obra de Platão que a máxima ganha certo protagonismo e, ainda associada à figura de Sócrates, passa a ser investigada em sentido mais aprofundado, e chega a sofrer uma significativa inflexão de significado - algo que há de se relacionar estreitamente com a prática da reflexão autobiográfica, tanto nos diálogos quanto, presumivelmente, no texto da Carta VII. Antes no entanto de proceder a uma análise dessa questão nos escritos de Platão, é preciso que nos detenhamos por um instante sobre alguns dos espinhosos problemas que se insinuam quando procedemos a uma reflexão filosófica sobre a ideia de "conhecerse a si mesmo". 


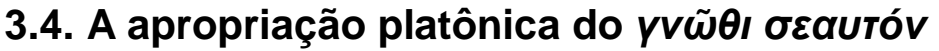

São nada menos do que seis os diálogos platônicos em que o preceito délfico faz alguma aparição explícita - e, conforme veremos, também a Carta VII. Em alguns, como o Fedro, ele é apenas mencionado de passagem. Em outros, como o Protágoras, ele é um tema diretamente debatido. E, no Primeiro Alcibíades, ele é o próprio tema principal e o motor de toda a discussão. São os primeiros registros de que dispomos de uma apropriação explícita que transforme a frase, de preceito de vida, em questão filosófica, ou em um objeto de investigação. Aqui será feita uma análise mais detida da apropriação que Platão faz do preceito do autoconhecimento - porque, seguindo a leitura que Julia Annas propôs sobre o tema, defendemos que a filosofia de Platão desencadeia uma transformação na maneira como a ideia de "conhecer-se a si mesmo" era entendida - e, conforme veremos, essa transformação se relaciona de maneira muito direta com a leitura que esta pesquisa propõe da Carta VII.

$\mathrm{Na}$ cultura grega anterior ao impacto socrático e platônico, o autoconhecimento não era um imperativo de conhecer a própria interioridade, as profundezas da própria psique ou do próprio ego, e sim de ter plena ciência do seu lugar na sociedade humana, do seu papel na trama hierárquica da pólis. Diz Annas $^{133}$ :

no mundo a personalidade individual não era o 'si mesmo' (self) relevante a se conhecer. O que é relevante é conhecer-me a mim mesmo no sentido de conhecer o meu lugar na sociedade, saber quem eu sou e onde eu me encontro em relação aos outros. $\mathrm{O}$ autoconhecimento que é sophrosyne nada tem a ver com meu subconsciente e tudo a ver com 'minha situação e meus deveres'.

133 "Self-knowledge and early Plato", in Platonic investigations. Studies in philosophy and the history of philosophy, Vol 13, ed. D. J. O'Meara. Washongton, 1985. 
A esse sentido eminentemente político e social seria preciso ainda acrescentar um outro, certamente importante se levarmos em consideração que o preceito figurava no pórtico de um templo dedicado a um deus: antes da “intervenção platônica", o $\gamma v \tilde{\omega} \theta \imath$ $\sigma \varepsilon \alpha v \tau o ́ v$ não apenas envolvia conhecer o papel do polités diante da sociedade humana, mas também punha o imperativo de conhecer o seu próprio lugar na economia cósmica, diante dos deuses e da própria physis. A ideia central seria a de conhecer as limitações do modo humano de vida, cujas fronteiras não devem ser jamais ultrapassadas, sob a pena de conjurar contra si os trágicas consequências trazidas pela hybris. Exibida no umbral de um templo em que, acreditavam os gregos, o mortal estaria na presença de um deus, a frase pode ser interpretada como um alerta ou uma reprimenda, como se fosse dito: "põe-te no teu lugar".

Seja como for, e fossem quais fossem as dificuldades implicadas, é fato que o preceito de autoconhecimento parecia ter de fato, na cultura grega pré-filosófica, um sentido "exterior" - social, religioso ou cosmológico - antes de um sentido de um mergulho vertical nas profundezas da própria interioridade.

Não é de espantar que a noção de autoconhecimento sofra uma inflexão na filosofia socrático-platônica, se levarmos em consideração que a própria noção de "individualidade humana" também foi inteiramente retrabalhada pelo pensamento de ambos. Passemos a uma análise do tema, antes de relacioná-lo mais diretamente à Carta VII.

Uma interpretação possível dos primeiros diálogos de Platão é a de que ele traça o retrato de um filósofo que, embora se frustre na investigação de vários temas importantes (a natureza de coisas como a piedade, a coragem, a amizade etc.), ainda assim chega ao conhecimento mais importante e mais filosófico de todos: o conhecimento de si próprio. Essa leitura corroboraria uma tese apresentada no Primeiro Alcibíades: o autoconhecimento é o saber próprio dos filósofos, e todos os demais dependem e derivam dele. Essa não parece ser, no entanto, a palavra final do conjunto dos diálogos a esse respeito. Nas obras ditas "da maturidade", surge um elemento que complexifica imensamente a questão: a existência de uma alma imortal e incorpórea, sede da cognição e natureza última da forma humana. Para agravar a questão, diz-se dessa alma ter dois modos distintos de existência: um ao 
estar unida a um corpo e ter contato com os seres sensíveis; outro, separada de qualquer corpo, ao contemplar as formas eternas. É notório que essa proposição, metafórica ou literal, supõe um outro tipo de "si mesmo" a ser devidamente conhecido - e é isso que aqui nos cabe explorar.

Antes de mais nada, é pertinente desenvolver a ideia de Sócrates como uma espécie de mestre do autoconhecimento. Tão famosa quanto a reiterada afirmativa socrática a respeito de nada saber é o fato de que ele aceitou o vaticínio do Oráculo de Delfos sobre ser o homem mais sábio da Grécia justamente por ter consciência da própria ignorância. Não é preciso insistir em um ponto aqui tão notório: sob certo aspecto, Sócrates se considerava, sim, um sábio, mas não por deter o tipo de conhecimento que os indivíduos afamados por seus saberes detinham, e sim por ter consciência da própria ignorância. Gregory Vlastos ${ }^{134}$ estabeleceu uma distinção que se tornou um marco interpretativo nos estudos sobre Platão: a distinção entre o saber "de expert", ou conteudístico, e o saber "do elenchos". Ele identifica o saber "de expert" como sendo de tipo dedutivo: o conhecimento que se deduz de princípios fundamentais e auto-evidentes, e que seria necessário e indubitável. Sócrates não seria possuidor de nenhum tipo de "saber de expert", mas sim de "saber de elenchos", que se obtém quando uma determinada ideia, argumento ou proposição é submetida a uma análise refutativa. Ao contrário do "saber de expert", o "saber de elenchos" estaria sempre sujeito a escrutínio e refutações em discussões futuras, e é portanto sempre provisório e aberto a questionamentos.

Essa distinção proposta por Vlastos exerceu grande influência, muito embora outros estudiosos tenham apresentado algumas ressalvas a respeito da natureza do saber positivo que Sócrates negava possuir - Nehemas ${ }^{135}$ e Woordruff $^{136}$, por exemplo, rejeitam que fosse um saber de tipo dedutivo, e sim, conforme aliás é dito de maneira mais ou menos explícita na Apologia, um saber técnico, ou o domínio de alguma arte. Independentemente dessa questão, seguimos

\footnotetext{
${ }^{134}$ VLASTOS, G. Socratic Studies (org. M. Burnyeat). Cambridge: Cambridge University Press, 1994. pp. 42-48.

${ }^{135}$ NEHEMAS, A. The art of living: Socratic reflections from Plato do Foucault. Berkeley: University of California Press, 1999. pp. 73-80.

${ }^{136}$ WOORDUFF. "Plato's earley theory of knowledge", in Essays on the Philosophy of Socrates (org. H. Benson). Oxford: Oxford University Press, 1992. pp. 86-106.
} 
aqui a contribuição de Andrea Nightingale ${ }^{137}$, segundo a qual Sócrates alega possuir um outro tipo de saber positivo, que não se confunde com o elenchos: o saber de si próprio, ou o autoconhecimento. O que o filósofo diz ser a ignorância dos seus contemporâneos é fundamentalmente diferente da ignorância que ele próprio ostenta como um valor - a qual resulta de um diligente e mesmo doloroso processo de investigação de si mesmo. Não se trata, evidentemente, de inspecionar a presença ou ausência de conhecimento positivo, mas sim de uma avaliação de caráter ético sobre o espírito crítico quando direcionado a si próprio. C. D. D. Reeve afirma que é necessário que Sócrates reclame para si alguma forma especial de conhecimento, por que, "de outra forma, qualquer um que reconheça não possuir conhecimento teria a sabedoria humana e seria tão sábio quanto Sócrates, mesmo que o seu reconhecimento de ignorância fosse o resultado de um simples ceticismo ou de uma inteligência abaixo da média"138. A sabedoria socrática seria, portanto, uma combinação de reconhecimento de ausência de saber com uma asserção positiva de um conhecimento ético baseado em um saber diferente do do expert. Ou seja: pessoas pouco inteligentes não podem chegar ao conhecimento socrático simplesmente afirmando não saber algo, ou levianamente alegando nada saber. Somente um filósofo poderia vislumbrar seus limites cognitivos. De fato, o conhecimento socrático é um conhecimento "positivo" sobre o seu estado epistêmico, mas distinto de um conhecimento propositivo. E, para o Sócrates dos primeiros diálogos platônicos, e mesmo para o Sócrates que figura no Teeteto e no Fedro, conhecer-se a si próprio é condição anterior e indispensável para a ação moral. Uma pessoa que ignore a si mesmo não pode tomar boas decisões e inevitavelmente vai incorrer em más ações.

\footnotetext{
${ }^{137}$ NIGHTINGALE, A. "Plato on aporia and self-knowledge", in Ancient Models of Mind. Studies in Human and Divine Rationality. (org. A. Nightingale \& D. Sedley). Cambridge: Cambridge University Press, 2010.

${ }^{138}$ REEVE, C. D. D. Socrates in the Apology. Indianapolis: Hackett Publishing Company, 1989. p. 35 .
} 


\subsubsection{O Cármides}

Vejamos brevemente a discussão empreendida no diálogo Cármides, que propõe uma extensa investigação em torno do tema do autoconhecimento. São muitas as questões difíceis levantadas a esse respeito na obra - que aliás termina em uma aporia, mas não sem antes deixar como rastro uma série de discernimentos. A última parte do diálogo revolve em torno da afirmação de Crítas, segundo a qual a sophrosyne se identifica inteiramente com o conhecimento de si, e em torno das refutações socráticas a esse respeito. Essa discussão começa com Crítias afirmando, no passo 165b, que quando Sócrates nega que a sophrosyne seja o autoconhecimento (tò gignwskein autòn eautón), ele próprio “dá uma demonstração justamente disso" (toútou soi didó- nai lógon). Sócrates então pergunta se há ou não um objeto do autoconhecimento que seja distinto do conhecimento ele próprio. Crítias então responde que a sophrosyne é distinta dos outros saberes justamente pelo fato de que ela não tem algo distinto de si própria como objeto, mas antes é "um conhecimento de outros conhecimentos e de si mesmo" (166c-e). Note-se que, com isso, Crítias promove um desvio do preceito délfico sobre "conhecer-se a si mesmo" para uma concepção bastante diferente de autoconhecimento como "saber de outros saberes". O critério pode servir para aferir o nível de conhecimento de si e dos outros, na medida em que discerne aquilo que o conhecimento é, mas pouco parece se relacionar com algum preceito de aperfeiçoamento moral. Sócrates então persegue a noção de "saber dos saberes" (175a-c) e, ao vê-la problemática, encerra o diálogo em uma aporia, afirmando ainda que a investigação não produziu "nada de bom". Sócrates não questiona a definição inicial, e apenas explora as suas fragilidades. Mas é importante notar que, quando Crítias apresenta a sua definição de sophrosyne, Sócrates diz que o seu próprio objetivo é o de "investigar a mim mesmo e o que digo, pois temo que inadvertidamente possa pensar que sei algo, quando não o sei” (166c-d). Ele portanto rejeita um conhecimento técnico de um "saber dos saberes", ao mesmo tempo em que exibe uma consciência de si que é parte de uma sabedoria ética e moral. Crítias, ao contrário, recusa um confronto com a própria ignorância:

S: Quando Crítas ouviu essas coisas e viu que eu estava em estado de aporia, ele pareceu tomado pela aporia ele 
próprio por causa da minha aporia - como aquelas pessoas que veem alguém próximo bocejar e são afetadas da mesma maneira. Mas como ele sempre buscava uma boa reputação, ele teve vergonha de admitir diante dos presentes que não podia se decidir sobre as coisas que eu lhe perguntava, e então disse algo muito vago, escondendo a sua própria aporia. $(169 \mathrm{c}-\mathrm{d})$.

O trecho deixa claro que a vaidade e o desejo de boa fama de Crítias o impediram de encarar a própria ignorância (veremos, mais adiante, que essas características serão dois dos traços distintivos da personalidade de Dionísio II, tal como descrito na Carta VII). Sua inabilidade de conhecer a si mesmo é um malogro ético tanto quanto epistemológico. E, no mesmo trecho, é interessante dar atenção ao uso do termo aporia como consciência da própria ignorância. De fato, é possível então definir a aporia socrática como sendo a combinação da falta de conhecimento sobre algo com o vislumbre autoconsciente dessa falta. A aporia portanto não é a mera ignorância, neutra do ponto de vista moral, mas sim a conjunção de componentes éticos e epistêmicos. E é essa aporia, com sua dimensão ética de autoconhecimento, que ele tenta despertar em seus interlocutores. E, de fato, em muitos casos o leitor tem a impressão de que o propósito do personagem Sócrates, tanto nos diálogos iniciais quanto nos ditos "da maturidade" ou "tardios", não é tanto o de analisar questões até o ponto de mostrar o quão problemáticas elas são, mas sim o de conduzir seus interlocutores até o vislumbre da vastidão da própria ignorância. Mostrar aos pretensos sábios de Atenas que eles não possuem saber nenhum é a sua maneira de servir ao deus Apolo (Apologia 23b) e de socorrer os mesmos compatriotas (30d-31b). O indivíduo que ganha essa consciência há de se tornar, acredita ele, uma pessoa melhor. A menção ao deus do "conhece-te a ti mesmo" não há de ser aí casual, como tampouco há de ser casual o fato de que ele recebeu sua missão filosófica justamente do Oráculo de Delfos. A presunção de sabedoria não é apenas um neutro equívoco em termos de avaliação cognitiva, e sim um problema moral. E é dessa maneira que a passagem da mera ignorância para o estado de aporia filosófica constitui um relevante aprimoramento ético, ainda que a pessoa que empreende essa passagem possa ainda nada conhecer a respeito da virtude. No fim das contas, ela livrou-se da vaidade e da autoilusão. 


\subsubsection{O Primeiro Alcibíades: o "si mesmo" não é um dado, mas uma questão}

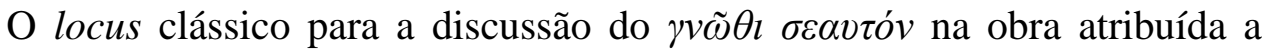
Platão é sem dúvida o Primeiro Alcibíades. Trata-se, claro, de obra de autoria controvertida - assunto que não será discutido aqui. Bastará, para os presentes fins, lembrar alguns fatos notoriamente $\operatorname{conhecidos}^{139}$ : o diálogo era considerado na Antiguidade a melhor obra de introdução para o pensamento de Platão; os que contestam a autoria a atribuem, na totalidade ou em parte, aos primeiros membros da Academia, e talvez ao próprio Aristóteles; os temas e assuntos abordados são todos compatíveis com os demais diálogos, e a maior parte dos temas ali abordados também o são em outras obras de autenticidade não controversa. A mais recente estilometria tem confirmado a autoria platônica da obra ${ }^{140}$, mas isso não vem ao caso: importa-nos, no momento, apenas que seja um diálogo com uma temática que possa ser reconhecida como tipicamente platônica - o que é perfeitamente notório.

O ponto a ser aqui observado é que o Primeiro Alcibíades é uma obra que opera, ela própria, uma transição fundamental na compreensão do "conhece-te a ti mesmo" - de alguma maneira, toma-o no sentido político e exterior que era difundido na Grécia e torna-o uma investigação da dimensão da interioridade humana, ou seja, da própria alma. Vejamos brevemente como isso se dá.

Alcibíades pretende interferir nos assuntos de Estado, naqueles que regem “sobre a guerra e a paz", e de apresentar-se como conselheiro dos atenienses. Sócrates diz crer que o jovem é movido por um desejo de mostrar-se grande, maior que o próprio Péricles (105b), tão grande quanto Ciro e Xerxes (105c). Alcibíades não o nega. Segue-se então uma longa primeira parte do diálogo, em que Sócrates demonstra que só é possível ensinar aquilo que se conhece, e que Alcibíades tudo ignora sobre o justo, o nobre e o vantajoso. Mais do que isso, Alcibíades não sabe nem mesmo quem são seus verdadeiros adversários - crê serem os rivais na política

\footnotetext{
${ }^{139}$ DENYER, N. "Introduction", in PLATO. Alcibiades. Cambridge: Cambridge University Press, 2001. pp. 1-26.

${ }^{140}$ V. a esse respeito, YOUNG, C. M., "Plato and Computer Dating", in SMITH, N. D. (org.), Plato: Critical Assessments volume 1: General Issues of Interpretation. Londres: Routledge, 1998. pp. 2949.
} 
ateniense, quando na verdade são os persas e os lacedemônios. É nesse contexto que a máxima délfica é citada pela primeira vez, em 124b: "Deixa-te persuadir, ao mesmo tempo por mim e pela inscrição de Delfos, 'conhece-te a ti mesmo', de que são estes os teus rivais, e não aqueles que crês." No contexto, o trecho traz um recado claro: persas e espartanos são povos de excelência e cheios de virtude; se os atenienses quiserem fazer frente a eles, precisarão se aperfeiçoar pela aplicação


saber a quem se pode fazer frente, é conhecer as próprias forças e fragilidades - e, a partir disso, trabalhar na direção do melhoramento de si. Aqui, o preceito é tido como algo não problemático, e como uma orientação de vida transparente e com a qual todos concordam.

É a partir desse consenso em torno da ideia que Sócrates passa a inquiri-la filosoficamente: se o sapateiro só pode melhorar os sapatos porque os conhece, da mesma maneira é preciso conhecer o "si mesmo" a ser aperfeiçoado. É quando ambos reconhecem: o preceito délfico encerra um enigma (129a):

Sócrates: É coisa fácil conhecer-se a si mesmo, e quem escreveu esse preceito no templo de Pito era um homem insignificante? Ou é uma tarefa difícil, que não está ao alcance de todos?

Alcibíades: A mim, Sócrates, ela me pareceu frequentemente estar ao alcance de todos, mas frequentemente também tudo o que há de mais difícil.

A resposta de Alcibíades é extremamente significativa: parece referir-se a uma acepção simples, talvez corrente do preceito, e talvez mais aparentada com aquela aludida anteriormente. Ou, dito ainda de outra forma: talvez o trecho apenas registre que Alcibíades percebe que há uma falsa simplicidade no preceito, na medida em que, de alguma forma e em algum nível, todos os seres humanos sabem quem são. O próprio diálogo parece fazer referência a isso logo a seguir, em 129b, numa passagem que, em qualquer outro contexto, haveria de parecer injustificavelmente estranha: 
Sócrates: Com quem estás conversando agora? Comigo, não é?

Alcibíades: Sim.

Sócrates: E eu, por minha vez, contigo?

Alcibíades: Sim.

Sócrates: Então é Sócrates quem fala?

Alcibíades: Certamente.

Sócrates: E o ouvinte é Alcibíades?

Alcibíades: Sim.

Existe um nível em que conhecer-se a si mesmo é mais do que simples: é óbvio e instintivo. Segundo nos parece, ela complementa uma outra passagem, 121a, em que ambos os personagens mencionam suas nobres linhagens ancestrais - as duas combinadas remontam ao modo de apresentação dos personagens dos épicos homéricos, ou seja, o nome e a linhagem. Se a investigação do "conhece-te a ti mesmo" precisa prosseguir, é porque a questão tem camadas distintas e comporta elementos imprevistos e na verdade bastante enigmáticos, e saber usar o

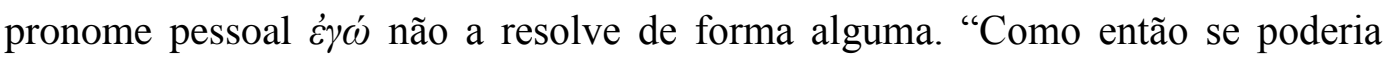

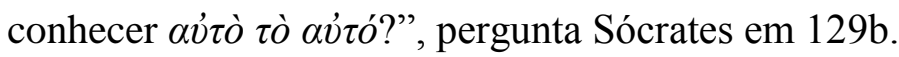

A resposta passará por duas etapas sucessivas. A primeira será o reconhecimento de que o ente humano é a sua alma, e de que o corpo é como que o seu instrumento (128e-130a). Conhecer a si mesmo é, portanto, conhecer a própria alma; só depois desse reconhecimento será possível empreender o aperfeiçoamento de si mesmo, ou seja, o aperfeiçoamento da alma (132c). E é então que Sócrates, depois de prometer desvendar de uma vez por todas o sentido último do preceito délfico, propõe a metáfora da visão: um olho é incapaz de ver-se a si próprio, mas pode ver-se na pupila de outra pessoa (132d-133b). Isso equivale a que a alma não apenas veja-se em outra alma, mas naquilo que ela tem de mais elevado, a sede mesma da sua sabedoria, onde ela "se assemelha a um deus" (133c). É o convívio com os sábios, portanto, que levará o indivíduo na busca pelo autoconhecimento.

Por fim, além disso, é preciso notar que Sócrates deixa ainda um discernimento pelo caminho, embora não o explore muito detidamente: conhecer a 


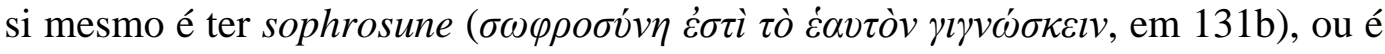

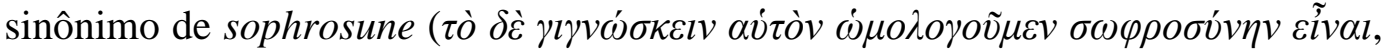
133c). Se a ideia não é desenvolvida, e se tampouco é feita uma distinção entre o ato de conhecer-se a si mesmo e os seus resultados, isso, para os presentes fins, pouco importa. O que nos interessa de maneira direta é a inflexão do significado do "conhece-te a ti mesmo" uma vez que ele foi apropriado pela filosofia como questão a ser dialeticamente inquirida.

A conclusão que se tira da leitura do Primeiro Alcibíades é uma complexificação formidável do preceito délfico: primeiro, reconhece-se que o sentido da frase não é nada óbvio; segundo, distinguem-se os níveis individual e universal do "si mesmo" a ser conhecido; terceiro, insere-se um outro elemento, uma outra camada na coisa investigada - a alma, ela própria constituída por "partes", as quais podem ser menos ou mais nobres; quarto, com o paradigma óptico, propõe-se um método razoavelmente sofisticado de procedimento investigativo - um observar-se a si próprio na relação com outros indivíduos sábios. Além disso, o diálogo conclui que o conhecimento próprio do sábio ou do filósofo é conhecer-se a si mesmo (131a-b). Afirma também que só é feliz o sábio que alcança o autoconhecimento (134a-b), que só um sábio dessa estatura deveria governar sobre os demais (133d-e), e que um tirano que tudo ignora sobre si próprio é o pior dos males (135a-b).

Todo o encaminhamento desse diálogo parece ter estreitíssima relação com tudo aquilo que é dito na Carta VII. Já foi defendida a tese ${ }^{141}$ de que o personagem Alcibíades nesse diálogo espelha Dionísio II, e que as lições que Sócrates lhe ensina são tudo aquilo que Platão gostaria de ter podido ensinar ao próprio tirano. As relações não são superficiais: o tirano ignorante como o pior dos males; o escrúpulo de antes educar-se diligentemente para só depois entregar-se à arte de governar; a importância da sophrosune para aqueles que se dedicam à política. Uma referência especial intensifica a relação entre os dois textos: em 125e, Sócrates e Alcibíades concordam que a mais nobre arte a capacitar o bom governante é o "bom

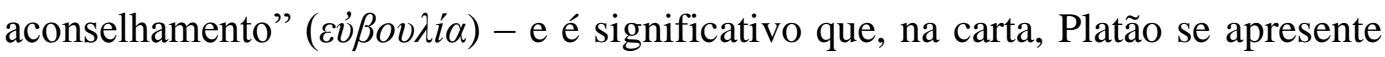

\footnotetext{
${ }^{141}$ cf. DENYER, "Introduction”, op. cit.
} 
reiteradamente como o conselheiro dos atores políticos, e que afirme ter sido esse o serviço que tentou prestar a Dionísio II.

É digno de nota que se relacionem de maneira tão próxima o diálogo que tematiza filosoficamente o $\gamma v \tilde{\omega} \theta l \sigma \varepsilon \alpha v \tau o ́ v$ e o texto autobiográfico de Platão - e tais relações seguiriam perfeitamente relevantes caso considerássemos um desses textos, ou mesmo ambos, como apócrifos. Conforme veremos, o preceito délfico também faz uma aparição de especial importância na Carta VII.

\subsubsection{Protágoras, Fedro, Filebo, Leis. Um exame da apropriação filosófica}

Embora certamente aquilo que de mais importante sobre o preceito tenha sido dito no Primeiro Alcibíades, é digno de nota que a frase de Delfos também faça aparições explícitas em outros diálogos: o Protágoras (343b), o Fedro (229e), o Filebo (48c) e Leis (923a). Se as menções do Protágoras e de Leis são colaterais, embora certamente não irrelevantes, no Filebo e no Fedro as coisas ganham outras cores, e é o caso de apresentar uma breve consideração a respeito.

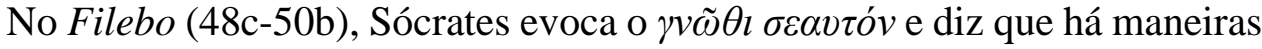

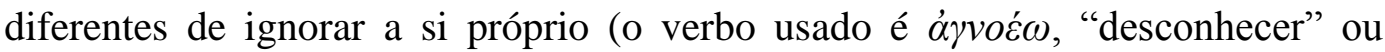

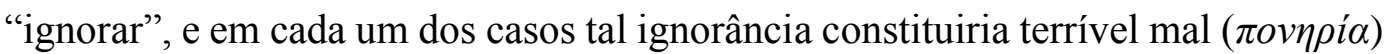
para o sujeito em questão. Há os que desconhecem a extensão de seus bens e riquezas; há os que se enganam a respeito de seus corpos, supondo-se mais belos ou fortes do que são; mas há o mal maior, o daqueles que se enganam a respeito das próprias almas. Estes últimos julgam-se mais virtuosos do que são e, dentre as virtudes sobre as quais mais se enganam, a mais frequente é justamente a sabedoria ( $\sigma o \varphi i \alpha)$. Tal é um mal que acomete a maioria dos homens (49b). Este último é um dado novo em relação às considerações contidas nos demais diálogos, embora seja uma derivação direta da relação que amiúde se estabelece entre o "conhece-te a ti 
mesmo" e a conquista da consciência da vastidão da própria ignorância - um tema, evidentemente, muito socrático.

Já no Fedro, o preceito ganha cores algo inesperadas. Sócrates e seu interlocutor conversam de passagem sobre acontecimentos míticos que, segundo contavam, teriam acontecido no lugar onde se encontram para conversar - fora dos muros da cidade, nas margens do Ilisso. Sócrates tece algumas considerações sobre versões e interpretações dessa história, e então observa (229e-230a, na tradução de Carlos Alberto Nunes):

Perderia um tempo enorme o incrédulo que, armado apenas da vulgar sabedoria, se impusesse a tarefa de deixar aceitáveis todos esses monstros compósitos. E a razão, amigo, é a seguinte: até agora não fui capaz de conhecerme a mim mesmo, conforme aquilo do Oráculo de Delfos, donde parecer-me ridículo estudar coisas estranhas antes de saber quem sou. Por isso, digo adeus a essas histórias e me contento com a opinião comum. Como disse há pouco, em lugar de investigar essas coisas, cuido apenas de examinar-me. Quero saber se sou algum monstro mais complexo e cheio de fumo do que Tífon, ou algum ser delicado e simples, que, por natureza, participe de um destino de algum modo divino e sem fumos de qualquer espécie.

Na primeira parte do trecho, temos a reiteração de um preceito que, a essa altura, já podemos chamar de "tipicamente platônico": o conhecimento de si tem precedência sobre os demais tipos de conhecimento, e é uma espécie de prérequisito para os demais saberes. Se Sócrates interrompesse sua fala ali, não haveria grande novidade. Mas imediatamente depois ele prossegue para dizer algo bastante interessante: ele se refere à sua própria interioridade não apenas como algo misterioso, mas a compara a algo ao menos potencialmente formado pelos mesmos elementos de que se compõem os antigos mitos: talvez haja nele um monstro como Tífon, ou talvez haja algo de divino. Parece haver aí uma insinuação, e a possibilidade de uma interpretação: a de que as realidades de que falam as antigas histórias podem ser encontradas ou investigadas no interior da própria alma 
humana. Não há razão para perscrutá-las como algo exterior aos seres humanos, se também dentro de si próprio embates semelhantes se dão.

O trecho é importante e significativo por uma razão bastante direta: ela pode nos ajudar a compreender de que maneira uma certa noção de "individualidade" está sendo forjada, especialmente se contrastarmos essa ideia com as considerações apresentadas por Snell, Schmitz e Dodds: se nos tempos homéricos as paixões e impulsos que se apresentam ao ser humano são descritos como forças exteriores que simplesmente se abatem sobre eles, aqui eles são tidos como premências interiores. Isso, em alguma medida, parece querer dizer: são embates sobre os quais os indivíduos têm algum controle, alguma ingerência ou, no mínimo, alguma capacidade de resistência. Seria uma maneira de encontrar, já de alguma maneira teorizada e consciente nos diálogos de Platão, a tese da "interiorização das emoções", mencionada acima.

Tal leitura pode ser corroborada por uma comparação com todas as considerações apresentadas no segundo discurso de Sócrates, sobre a natureza da alma humana, em 245c-249d: a psique humana é como uma carruagem puxada por dois cavalos de naturezas distintas; há, no entanto, um cocheiro que a pilota. Não interessa quais pressões se abatam sobre o indivíduo, há nele um centro decisório e de volição, com a possibilidade de decisão sobre ela, com um centro de comando claramente estabelecido - tudo aquilo que, segundo Snell, estava ausente do personagem homérico, tal como descrito na Ilíada e na Odisseia. Veremos a importância dessas ideias em uma interpretação filosófica do relato autobiográfico da Carta VII.

Seja como for, já é possível perceber alguns pontos de imensa relevância que resultam da apropriação filosófica do preceito délfico nos escritos de Platão. Listemo-los abaixo.

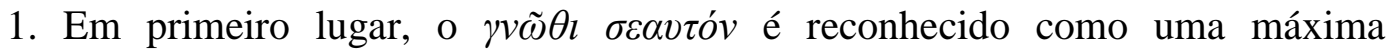
problemática, não óbvia, e uma tarefa que muitos são incapazes de cumprir simplesmente por não compreender qual tipo de trabalho ela encerra ou propõe.

2. Em segundo lugar, ela claramente deixa de se referir a uma acepção puramente política, como a de um cidadão que precisa conhecer seu lugar na pólis, ou 
meramente religiosa, em que um mortal deve conhecer sua fragilidade diante dos imortais, e passa a ganhar o sentido de uma investigação interior, que remete ao problema filosófico da natureza do "si mesmo" a ser conhecido.

3. Em terceiro lugar, dada a concepção ontológica de Platão a respeito da natureza humana, o imperativo de conhecer-se a si mesmo ganha a acepção de investigar a própria alma - com todas as nuances e dificuldades aí apontadas. Conforme é indicado no próprio Primeiro Alcibíades, e conforme é também afirmado em diálogos como a República e o Fedro, a psique humana não é uma unidade simples, mas um compósito formado por partes que podem estar, e frequentemente estão, em conflito, ou ao menos em desarmonia.

4. Em quarto lugar, opera-se uma inversão bastante curiosa: se conhecer-se a si mesmo, no contexto da tradicional religião políade, tinha o sentido de "aperceberse da condição de mortal", ou de dar-se conta da própria precariedade, perecbilidade e limitação, na obra platônica o autoconhecimento leva à consciência da existência de uma dimensão imortal do próprio indivíduo: a sua essência mesma, o seu $\alpha \dot{\tau} \tau o ̀$

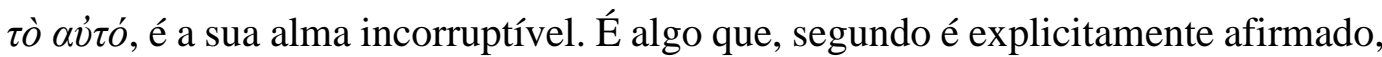
tem um traço divino, que se confunde com a própria capacidade pensante. Conforme se diz no Primeiro Alcibíades, viver filosoficamente é arrebatar o autoconhecimento, e arrebata-lo, por sua vez, é viver "divinamente".

Feitas essas considerações, já é possível relacionar o imperativo do Oráculo de Delfos a outro elemento da obra escrita de Platão: o preceito da "vida examinada", de que trataremos a seguir.

\subsubsection{A "vida examinada": o preceito délfico também no tempo, não apenas no espaço}

Além da ideia de uma investigação estrutural da forma humana, além de um processo contemplativo que leve o indivíduo a conhecer em si sua dimensão anímica e imortal, o $\gamma \nu \tilde{\omega} \theta \imath \sigma \varepsilon \alpha v \tau o ́ v$ parece ganhar uma outra dimensão nos escritos 
de Platão: a dimensão do escrutínio da trajetória biográfica, ou o preceito da "vida examinada", conforme é dito na Apologia de Sócrates. Em mais de uma ocasião nos diálogos, esse preceito ganha a forma de uma apresentação de uma narrativa autobiográfica que dê conta de explicar a situação existencial concreta do sujeito, de maneira que ele mostre estar consciente daquilo que está fazendo, e de como foi parar nas circunstâncias que ora o cercam. Talvez seja possível interpretar esse duplo desdobramento do "conhece-te a ti mesmo" como um exaurimento da questão: conhecer a estrutura da forma humana; conhecer também a maneira como ela se manifestou concretamente na trajetória biográfica. Seria um "exaurimento"

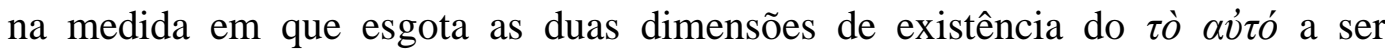
conhecido: o estrutural e o biográfico talvez possam ser vistos como o espelhamento da manifestação espacial e temporal do "si mesmo". Fato é que, independentemente dessa consideração, os diálogos trazem, em mais de uma ocasião, relatos autobiográficos altamente significativos, e carregados de importância filosófica. Passemos a alguns exemplos.

O imperativo délfico não é mencionado explicitamente em nenhum momento no texto da Apologia de Sócrates, embora seja claramente aludido no passo 28e: "recebendo ordens do deus (...) deveria viver filosofando e aplicandome a investigar a mim mesmo e aos outros" (


motor de toda a obra é bastante claro, por uma série de razões. Em primeiro lugar, Sócrates parece expor sua situação presente, de réu diante do tribunal ateniense, como a culminação natural e consciente de uma vida dedicada à filosofia. Essa vida deriva diretamente de uma missão revestida de caráter divino - missão recebida justamente no Oráculo de Delfos. É a testemunha do "deus de Delfos" que ele conjura como fiadora de seu relato (20e). O oráculo proferido pela Pítia imediatamente o leva a um processo de autoinvestigação e escrutínio de si próprio, e esse processo o leva também a inquirir os que eram reputados sábios em Atenas (21a-23a). É também o mesmo impulso dado pelo deus que o conduz à mais socrática de todas as conclusões (23a-c):

quem sabe é apenas o deus, e quer dizer, com seu oráculo, que pouco ou nada vale a sabedoria do homem, e, dizendo que Sócrates é sábio, não quer referir-se propriamente a 
mim, Sócrates, mas apenas usar meu nome como exemplo, como se tivesse dito: "Ó homens, é sapientíssimo entre vós aquele que, como Sócrates, tenha reconhecido que sua sabedoria não possui nenhum valor. Eis por que ainda hoje continuo procurando e investigando segundo a palavra do deus se há algum entre os cidadãos ou estrangeiros que possa ser considerado sábio e, como me parece que nenhum o seja, venho em ajuda ao deus demonstrando que não existe nenhum sábio. E tomado como estou pela ânsia de pesquisa, não me restou mais tempo para fazer algo considerável nem pela cidade nem pela minha casa e vivo em extrema miséria por este meu serviço ao deus.

Todo o empreendimento filosófico de Sócrates, toda a sua jornada de autoconhecimento e inquirição dos pretensos sábios, é creditada à divindade do "conhece-te a ti mesmo". Mais do que isso, recusa-se a abandonar a missão divina, mesmo que ela lhe custe a privação de bens, o exílio ou a morte (29d).

Tais considerações se relacionam inevitavelmente com o exame escrutinado da própria vida. O diálogo é evidentemente uma apologia pro vita sua - ou, melhor dizendo, não "uma" apologia pro vita sua, mas sim o protótipo e o modelo desse gênero, e mesmo um precursor evidente de todo o texto da Carta VII. Em 28b, Sócrates afirma não se importar com as punições ou com quaisquer outras consequências do seu modo de vida - pois não se trata de um capricho ou de uma veleidade, mas de um modo de vida que ele não pode, em boa consciência, abandonar. O réu sabe como e por que foi parar diante do tribunal: o julgamento é o resultado do contraste entre sua prática filosófica e a corrupção da pólis. Depois de condenado, sabe também por que o foi, e insinua ter antecipado o resultado. Que tudo está onde deveria estar, atesta-o o próprio daímon, que não o deteve em nenhum momento (40a-b).

Todo esse processo filosófico se encerra claramente na máxima: "a vida não examinada não vale ser vivida", proferida em 38a. O imperativo délfico não ganha portanto apenas os contornos de um exame estrutural da forma humana, mas também de um exame diegético: na narrativa consciente da própria vida, de maneira a dar conta das suas motivações filosóficas e de uma trajetória vital consciente de si. Em outras palavras, e valendo-nos de uma metáfora, talvez fosse possível dizer: 


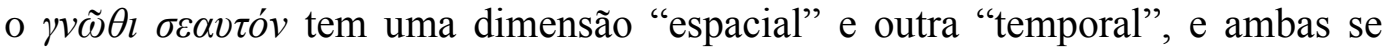
encontram claramente relacionadas no tex to da Apologia.

Não apenas na Apologia, é verdade. Também no Fédon uma ideia semelhante é apresentada, e aliás com a exposição também de um breve relato de um Sócrates condenado à morte (96a-100a), e que, antes de uma mera coleção de informações sobre sua vida, constitui uma verdadeira autobiografia filosófica: o saber que buscava, por que o buscava, e como isso afetou sua própria vida até forjar as convicções que o levavam a uma disposição serena diante da condenação à morte. É significativo que tal relato autobiográfico faça a passagem de uma aporia derivada de uma concepção puramente materialista do mundo, proposta por Cebes, e a contemplação das formas eternas, tal como as exporá Sócrates a seguir.

Mais significativa, no entanto, é a passagem em que Sócrates compara as duas dimensões - o tipo de busca filosófica que empreende e o desfecho da própria vida, no dia da própria condenação. Ao repreender o tipo de saber cultivado por Anxágoras, que propunha apenas uma descrição do cosmos e de seu comportamento, Sócrates diz ter sentido falta da busca de um outro tipo de aitía: aquela que explique por que o cosmos é como é. Não bastaria dizer que a Terra está no centro do universo, mas explicar por que seria esse "o melhor lugar para ela estar" (97e). Para ilustrar a questão, ele alude à própria situação: não é por ter tendões, músculos e ossos que ele se encontra sentado no cárcere. Se se encontra em tal lugar e situação, a melhor maneira de explicá-lo é dizer que (98d-99a, na tradução de Jorge Paleikat e João Cruz Costa):

estou aqui porque os atenienses julgaram melhor condenar-me à morte, e por isso pareceu-me melhor ficar aqui, e mais justo aceitar a punição por eles decretada. Estou convencido de que estes tendões e estes ossos já poderiam há muito tempo se encontrar perto de Mégara ou entre os Beócios, para onde os teria levado uma certa concepção do melhor, se não me tivesse parecido mais justo e mais belo preferir à fuga e à evasão a aceitação, devida à Cidade, da pena que ela me prescreveu!" 
E complementa, logo adiante (99a-b): "Mas dizer que é por causa disso [i.e., por ter ossos e músculos] que realizo minhas ações e não pela escolha que faço do melhor ( $\beta \varepsilon ́ \lambda \tau \imath \sigma \tau o \varsigma)$ e com inteligência - essa é uma afirmação absurda.” De tal testemunho, segue-se o corolário: mesmo diante da própria execução, Sócrates é possuidor da própria trajetória biográfica, e não um joguete inerme das circunstâncias. Sócrates sabe como e por que sua opção de vida o levou até ali, a um destino que não tentou evitar.

Se a Apologia e o Fédon podem ser considerados os testamentos filosóficos de Sócrates (ao menos do Sócrates que é personagem da obra de Platão), é significativo que, em ambos os diálogos, ele apresente relatos da própria vida, e, mesmo, autobiografias filosóficas. É também revelador que ele queira afirmar a autonomia plena sobre a própria vida, dar conta das suas escolhas e decisões, e arcar inteiramente com as consequências delas, em grande medida antevistas. Nas suas palavras, o tribunal ateniense e a cicuta são a própria culminação do $\gamma v \tilde{\omega} \theta \iota \sigma \varepsilon \alpha v \tau o ́ v$.

Pelo personagem Sócrates, Platão deixou um exemplo filosófico do preceito da vida examinada e do autoconhecimento. Conforme defenderemos na seção seguinte, na Carta VII ele o praticou de próprio punho. 


\section{A Carta VII, a vida examinada e o princípio da autopoiesis}

\subsection{A Carta VII como um texto filosófico}

Ponderadas todas as considerações do capítulo anterior - o gradual surgimento da noção de "indivíduo" na Grécia Antiga, o advento do imperativo "conhece-te a ti mesmo", e a apropriação filosófica dele por parte de Platão, culminando no preceito da "vida examinada" - não é difícil apresentar a tese que impulsionou a sua redação: a de mostrar a imensa importância da Carta VII, não como documento historiográfico ou fonte de informações, mas como uma obra filosófica. Aqui, é necessário passar a algumas considerações.

Mesmo os comentadores que defendem entusiasmadamente a importância da carta costumam dizer o seguinte a seu respeito: ela é uma documentação valiosa da situação política da Grécia, e em especial de Siracusa do séc. IV. Ela também é uma fonte indispensável de dados a respeito da vida de Platão. Na medida em que no excurso filosófico chega a adentrar temas relativos à ontologia, à teoria do conhecimento e à filosofia da linguagem, é também uma preciosa ocasião em que Platão tratou de questões desse tipo na primeira pessoa, e portanto um texto a ser usado como parâmetro de interpretação para os diálogos - sempre em termos conteudísticos.

Apenas a título de exemplo, vamos citar algumas dessas exposições. Diz Charles Taylor ${ }^{142}$ : "Se as epístolas são espúrias, perdemos uma das fontes diretas de informação sobre toda a biografia de Platão, e também a fonte da maior parte do que sabemos sobre os acontecimentos da Sicília entre 367 e 354”. Também Guthrie $^{143}$ : "Se [Platão] não a escreveu pessoalmente, seu valor histórico é pouco afetado, pois mesmo os céticos concordam em que deve ser a obra de um discípulo

\footnotetext{
${ }^{142}$ TAYLOR, C. Plato. Tha man and his work. NY: Dover, 2001. p. 14.

${ }^{143}$ GUTHRIE, A history of Greek philosophy: the later Plato and the academy, vol. 5. Cambridge: Cambridge University Pres 1978. p. 8.
} 
imediato, escrita antes ou logo depois da sua morte." Ou Bury ${ }^{144}$ : "Qualquer que seja a nossa posição sobre a autenticidade das cartas, é certo que algumas delas remontam a uma antiga tradição, de no máximo um século depois da morte de Platão, fonte para os detalhes históricos e biográficos que ela relata”. Brisson ${ }^{145}$ anota a importância de um texto de Platão em primeira pessoa, e de um documento que atestasse suas preocupações práticas e sua ação concreta na política. Há ainda também o caso dos partidários da escola de interpretação de Tübingen-Milão, que veem na VII um testemunho da existência das agrapha dogmata, ou das doutrinas não escritas de Platão ${ }^{146}$.

Pretendemos defender aqui uma tese diferente de todas essas: a de que toda a carta, justamente na medida em que é um discurso autobiográfico, é uma obra filosófica, inseparável das especulações platônicas a respeito da psique, do estatuto e da condição humana, da maneira como concebe o indivíduo e aquilo que constitui a sua experiência concreta de vida. Em outras palavras: depois de discutir o tema


inflexão em seu significado, apontando-o para a interioridade humana e suas motivações; depois de relacioná-lo claramente ao preceito de uma "vida examinada" que vale ser vivida; depois de tudo isso, Platão efetivamente redige um texto em que põe tais ideias em prática, e os demonstra a partir do mais relevante dos exemplos - a sua própria vida.

E o faz de mais de uma maneira. Em primeiro lugar, ele demonstra a perfeita continuidade entre o pensamento filosófico e a sua própria trajetória vital, com isso exibindo as motivações filosóficas das suas ações e decisões. Em segundo lugar, ele faz de Dionísio II uma espécie de contraexemplo, ao deixar manifesta a absoluta falta de autoconhecimento por parte do tirano de Siracusa. Há uma polaridade estabelecida entre os dois: se o saber mais próprio do filósofo é o de conhecer-se a si mesmo, e se todos os demais saberes derivam desse, Platão ele próprio termina a

\footnotetext{
144 "Introduction to the Epistles" in PLATO. Timaeus, Critias, Cleitophon, Menexenus, Epistles. Loeb Classical Library. Cambridge: Harvard University Press, 1929. p.390. 145 "Introduction", in PLATON. Lettres. Paris, Flammarion: 1987. pp. 9-10.

${ }^{146}$ V. por exemplo, REALE, G. "A grande importância da Carta VII para o pensamento de Platão", in Estudos Platônicos (org. Marcelo Perine). SP, Loyola: 2009. E um resumo da maneira como a carta se reporta a essa questão em KRAUT, R. "Introdução ao estudo de Platão", in Platão (org. Richard Kraut). SP, Loyola: 2013. pp. 56-57.
} 
Carta VII como um filósofo perfeitamente acabado, e Dionísio II como o oposto disso.

Dessas considerações, uma conclusão há de se insinuar: no pensamento de Platão, termina por se consolidar a ideia do ser humano plenamente autônomo, autor e causa de si mesmo - um princípio que, na falta de outro nome que possamos usar, vamos chamar de autopoiesis. As próximas páginas vão desenvolver e aprofundar essa questão.

Uma importante observação se faz necessária desde já. Não estamos afirmando que Platão tenha escrito a Carta VII apenas como demonstração prática de tais princípios, ou mesmo que tenha sido essa a sua principal motivação. É antes muito mais razoável supor que ele a tenha escrito pelas motivações expostas na própria epístola: posicionar-se politicamente diante dos acontecimentos de Siracusa, aconselhar os parentes e companheiros de Díon, condicionar seu apoio político a Hiparino II. É no entanto igualmente razoável supor que, se redigiu o texto como o redigiu, e se expôs tais ideias em íntima relação com o longo relato autobiográfico, é porque quis demonstrar a perfeita continuidade entre essas questões. Dizendo de outra forma: Platão parece ter usado essa ocasião para compor um texto que fosse, também, uma demonstração prática de alguns dos seus principais preceitos filosóficos sobre a continuidade entre reflexão teórica e vida concreta, ou um exemplo de como conhecer-se a si mesmo, ou de como viver a vida examinada - aquela “digna de ser vivida”. Seu caráter filosófico não se deve ao fato de ela ser um tratado ou uma exposição conceitual - coisa que ela claramente não é, exceto pelo trecho do excurso -, mas por ser, antes, um testemunho ou uma aplicação local de certos princípios que lhe eram filosoficamente caros, e com os quais o seu pensamento está arraigadamente comprometido.



Um elemento que salta aos olhos mesmo na mais superficial das leituras da Carta VII é esse: Platão pretende deixar cristalinamente claro aos seus 
interlocutores que suas ações e intervenções políticas em Siracusa foram diligentemente ponderadas segundo princípios filosóficos, que ele sabe precisamente por que razão empreendeu suas viagens à Sicília, e quais resultados estava tentando alcançar com elas. Suas decisões, como a de ceder aos pedidos de educar Dionísio II, e a de desistir abruptamente dessa educação logo no início da terceira estada, são expostos como resultados de deliberações cujas razões últimas poderiam passar despercebidas pelo público que leigamente observava os acontecimentos, mas que não obstante eram os seus motivos. Platão se apresenta como alguém que é plenamente dono da sua própria trajetória vital. Tais considerações podem parecer algo óbvias - mas, dentro do contexto em que se encontram, ganham dimensão filosófica de grande importância, como exporemos a seguir.

Conforme vimos nas seções anteriores deste mesmo capítulo, não era um dado comum à cultura grega dos tempos homéricos que o indivíduo tivesse plena ingerência sobre a própria vida. Por um lado, não tinha nenhum controle sobre as circunstâncias exteriores, que se abatiam sobre ele com a própria força da $\tau \dot{\chi} \chi \eta$, ou da "fortuna". Por outro, talvez ainda mais terrível, o indivíduo tampouco tinha o poder de manejar suas próprias motivações e estados de alma - tais estados podiam, e frequentemente eram, enviados pelos próprios deuses, de maneira inteiramente irresistível. Na verdade, se aceitarmos a tese de Schmitz anteriormente exposta, essa distinção faria pouco sentido: também as emoções e estados que chamamos de "interiores" eram tidos como incidências externas que se abatiam sobre os mortais.

O resultado é que os humanos tinham nenhuma ou pouca ingerência sobre a própria $\varepsilon \dot{\delta} \delta \alpha \mu o v i \alpha^{147}$ - uma dádiva que os deuses enviavam a seu bel-prazer para as pessoas que julgassem por bem agraciar. Igualmente forte é a ideia de $\varepsilon i \mu \alpha \rho \mu \varepsilon ́ v \eta$, a "porção que nos cabe" ou o "destino" aos homens reservado. São inúmeras as expressões dessa ideia na cultura grega anterior a Platão, e alguns exemplos bastarão para exemplificar a questão. É Heródoto quem registra, depois de relatar a terrível história do rei Creso, o oráculo que o rei deposto recebeu do Templo de

\footnotetext{
${ }^{147} \mathrm{O}$ termo é sabidamente de difícil tradução, e há sutilezas que o afastam da noção de "felicidade" nas línguas contemporâneas. Para todos os fins, optaremos por deixá-lo no original. Sobre isso, v. em especial ANNAS, J. The Morality of happines. Oxford: Oxford University Press, 1993. pp. $452-455$.
} 
Delfos: (Livro I, pár. 92, na tradução de Mário da Gama Kury): “Nem mesmo um deus é capaz de fugir ao destino prefixado. Creso pagou pelos pecados de seu antepassado da quinta geração.” Diz também o Corifeu, na conclusão da tragédia Édipo Rei (v. 1803 e ss., na tradução de Mário da Gama Kury):

Vede bem, habitantes de Tebas, meus concidadãos! Este é Édipo, decifrador de enigmas famosos; ele foi um senhor poderoso e por certo o invejastes em seus dias passados de prosperidade invulgar. Em que abismos de imensa desdita ele agora caiu! Sendo assim, até o dia fatal de cerrarmos os olhos não devemos dizer que um mortal foi feliz de verdade antes dele cruzar as fronteiras da vida inconstante sem jamais ter provado o sabor de qualquer sofrimento.

Ou ainda o coro que encerra a tragédia Medeia, de Eurípedes (v. 1415 ss., na tradução de Miroel Silveira e Junia Silveira Gonçalves):



A obra de Platão abre novas possibilidades de conceber a condição humana e a sua relação com o destino, como é evidente. Essas novas possibilidades se relacionam intimamente com a instauração dessa "dimensão interior" de volição e de escolha, sede das decisões humanas. O modelo maior e protótipo dessa nova condição nos é dado justamente pelo caso de Sócrates - que, lançado em circunstâncias exteriores verdadeiramente catastróficas, reafirma a sua autonomia e a boa ventura de seu fim. No caso, não é que o "destino" não se abata sobre ele mas importa antes a sua disposição a respeito desse destino. Diz Sócrates, na Apologia, logo antes do veredito (30c-d), na tradução de Jaime Bruna): 
Ficai certos de uma coisa: se me condenardes por ser eu como digo, causareis a vós próprios maior dano do que a mim. A mim dano algum podem causar Meleto e Ânito; eles não têm forças para tanto; não creio que os céus permitam que um homem melhor sofra danos de um pior. Eles podem, sim, mandar-me matar, exilar-me, privar-me dos direitos; talvez eles e outros pensem que essas são grandes desgraças; eu não; eu penso que muito pior é fazer o que ele está fazendo, tentando a execução injusta de um homem.

E, mais adiante, já condenado, e com a pena de morte já estabelecida pelo júri, e dirigindo-se aos juízes que o absolveram (40b-c, 41d-e e 42a, na tradução de Jaime Bruna):

Vou dizer-vos: é bem possível que seja para mim um bem o que aconteceu e não é forçoso que acertemos quantos pensamos que a morte é um mal. [...] Vós também, senhores juízes, deveis bem esperar da morte e considerar particularmente esta verdade: não há, para o homem bom, nenhum mal, quer na vida, quer na morte, e os deuses não descuidam de seu destino. O meu não é efeito do acaso; vejo claramente que era melhor para mim morrer agora $\mathrm{e}$ ficar livre de fadigas. [...] Bem, é chegada a hora de partirmos, eu para a morte, vós para a vida. Quem segue melhor rumo, se eu, se vós, é segredo para todos, menos para a divindade.

O sentido dessas falas é bastante claro, e ainda reforçado pela afirmação do Fédon, 99a-b, de que Sócrates considera que o cárcere da execução é o melhor lugar em que poderia estar. O filósofo pode chegar à $\varepsilon b \delta \alpha u \mu o v i ́ \alpha$ quaisquer que sejam as condições exteriores, porque sua felicidade ou plenitude depende apenas da maneira como dispõe da própria alma - algo que está sob seu pleno controle.

Uma ideia ainda mais forte do que essa é afirmada em outro diálogo: o Eutidemo. Conforme veremos adiante, esse trecho se relaciona intimamente com o texto da Carta VII, já que um exemplo muito semelhante é dado para ilustrar as circunstâncias de vida e de morte de Díon. Trata-se de um diálogo indireto, em que Sócrates narra a conversa que teve com Clínias sobre o bom sucesso dos homens (a expressão grega usada é ê̂ práttein, a mesma que inicia boa parte das cartas 
atribuídas a Platão, e a VII em particular). O trecho é grande, mas vale a pena reproduzi-lo na íntegra, pela relação direta que tem com o texto da epístola (279c280b, na tradução de Maura Iglésias):

- Pois bem, disse eu. Mas a sabedoria, em que lugar do coro a colocaremos? Entre os bens? Ou que coisa tens a dizer? / - Entre os bens. / - Reflete pois; não vá que deixemos de lado algum dos bens, algum justamente que seja digno de menção. / - Mas, parece-me, disse Clínias, <não teremos deixado> nenhum. / $\mathrm{E}$ eu, tendo-me lembrado, disse: Por Zeus! Corremos o risco de ter deixado de lado o maior dos bens! / - Qual é esse?, disse ele. / - A boa fortuna (Evitoxía), Clínias, isso que todos, mesmo os mais vis, dizem ser o maior dos bens. / - Dizes a verdade, disse ele. / - E eu, por outro lado, de novo mudando de ideia, disse: Por pouco não nos tornamos ridículos para esses estrangeiros, eu e tu, ó filho de Axíoco. / - Por que isso?, disse ele. / - Porque, tendo posto a boa fortuna entre os bens precedentes ainda agora, eis que de novo falamos da mesma coisa. / - E por que isso? / - É ridículo, sem dúvida, aquilo que já está estabelecido há muito tempo, isso de novo propor, e falar duas vezes as mesmas coisas. / - Que queres dizer com isso?, disse ele. / - Que a sabedoria, sem dúvida, é a boa fortuna, disse eu. E disso até mesmo uma criança se daria conta. / E ele espantou-se, tanto é ainda jovem e ingênuo. E eu, tendome dado conta de que ele se espantava, disse: / - Não sabes, Clínias, que no que se refere à realização bem-sucedida de árias de flauta, são os flautistas os mais bem afortunados? E no que concerne à escrita e à leitura das letras, são os gramatistas, não é verdade? E em relação aos perigos do mar? Crês, então, que haja pessoas mais bem afortunadas que os pilotos que sabem <seu ofício>, para dizer tudo? E, participando tu de uma expedição militar, com quem partilharias de mais bom grado o perigo e a fortuna: com um general que sabe <seu ofício>, ou com um que ignora? Então é porque crês que mais bem afortunado farias <algo>, fazendo-o com alguém que sabe, do que com alguém que ignora? / Ele estava de acordo. / - Logo, a sabedoria, em toda parte, faz os homens ser bem afortunados. Pois sem dúvida a sabedoria jamais erraria alguma coisa, mas, necessariamente, faz corretamente e alcança o resultado. Senão, não é?, não é mais sabedoria. / Acabamos por concordar, não sei como, que, em suma, as 
coisas se passam assim: se a sabedoria está presente, àquele em quem está presente, não é preciso, além disso, boa fortuna.

A ideia aí exposta contrasta claramente com ambas as anteriores: sabedoria e boa fortuna são a mesma coisa. O sábio não está exposto aos caprichos do destino, e não apenas por uma questão de disposições interiores, mas porque, sendo sábio, tem o poder de forjar a sua própria fortuna, e haver-se com as circunstâncias que sobre ele se abatem. Em ambos os casos, trata-se evidentemente de uma concepção antitrágica $^{148}$, sob vários aspectos. Veremos que, na maneira com expõe as coisas na Carta VII, Platão mitiga consideravelmente essa ideia - mas ainda assim faz alusão a ela, com o uso de uma metáfora praticamente idêntica.

\subsubsection{O princípio da autopoiesis na obra de Platão}

Se Platão não chega a usar o termo autopoiesis em nenhum de seus diálogos, existem alusões suficientemente claras que, segundo nos parece, nos autorizam a essa metáfora. Que o indivíduo humano tem sob seu poder a capacidade de decidir sobre si, e de optar por uma vida "divina", isso é afirmado em inúmeros diálogos. Essa é um princípio fundante da ética de Platão, exposto tanto sob a forma de arrazoados teóricos quanto sob a forma dos mitos escatológicos, como os de Er, no $\mathrm{X}$ da República, a escatologia do Górgias ou a narrativa central do Fedro. Mas a ideia que pretendemos avançar aqui propõe uma nuance um pouco diferente: a de que o indivíduo humano tem a possibilidade de forjar uma poiesis de si, tomando a própria $\psi v \chi \eta ́$ como o objeto de uma arte especial - ou como um artesão que tenha como obra a própria vida. Conforme veremos, tornar-se o autor da própria trajetória vital é uma condição a ser conquistada, ou arrebatada por aqueles que vivem uma vida filosófica. Veremos de que maneira essa ideia está presente em alguns

\footnotetext{
${ }^{148}$ Há inúmeros comentadores e intérpretes que exploram detidamente o caráter antitrágico da ética e mesmo da obra platônica. Para fins de brevidade, referimos aqui a apenas uma obra: NUSSBAUM, M. A fragilidade da bondade. Fortuna e ética na tragédia e na filosofia grega. SP: Martins Fontes, 2009, especialmente o capítulo "Interlúdio I: O teatro antitrágico de Platão".
} 
diálogos, e como Platão a aplicou ao redigir aquilo que pode ser lido como o drama da própria biografia.

Uma alusão clara a essa metáfora pode ser encontrada no diálogo Leis, em um trecho já citado anteriormente nesta pesquisa, mas em contexto bem diferente. O Ateniense e Clínias discutem, ao longo de todo o Livro VII, qual educação será provida aos cidadãos pelo Estado que estão concebendo. Em certo passo, o Ateniense diz que a vida nobremente vivida pelos $\pi$ ohĩ $\alpha_{l}$ exemplares serão o próprio modelo para a composição de hinos e canções (801e). Mais adiante, ao tratar da possibilidade de ter dentro da pólis a encenação de obras trágicas, o Ateniense diz que os dramaturgos deveriam ser recebidos com o seguinte discurso (817a, na tradução de Carlos Alberto Nunes):

nós também compusemos nossa tragédia, a melhor e mais bela que nos foi possível levar a cabo. Nossa constituição inteirinha não passa de imitação do que a vida tem de mais belo e excelente, imitação que nós, pelo menos, consideramos a verdadeira tragédia. Sois criadores, como também o somos, no mesmo gênero de poesia; concorrentes e rivais no mais belo drama que somente a verdadeira lei é capaz de realizar.

A ideia é aí apresentada em um nível coletivo: a vida dos cidadãos da boa pólis encenam a mais bela das obras dramáticas, de maneira que o tragediógrafo precisa provar estar em harmonia com os costumes e práticas ali cultivados antes de ser autorizado a exibir as suas peças.

Há uma outra ocasião, no entanto, em que a obra de Platão fala também de maneira explícita sobre uma "poética da $\psi v \chi \eta ் "$, desta vez em um nível individual, e comparando o forjamento de si com a obra dos grandes aedos. Trata-se de um trecho do discurso da sacerdotisa Diotima, no Banquete, a partir do passo 207d. A exposição ali apresenta a seguinte ideia: Eros se manifesta nos humanos como desejo da imortalidade, de transcendência da finitude que nos é constitutiva. "A natureza mortal procura, na medida do possível, ser sempre e permanecer imortal.

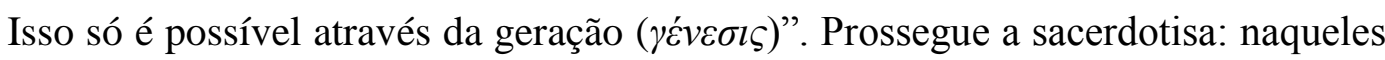
em que Eros é um impulso corpóreo, ele se manifesta na direção da procriação, da 
geração de novos indivíduos que sobreviverão ao que os gera. Mas não se trata da única maneira de buscar a imortalidade (209a): há também a procriação que se dá

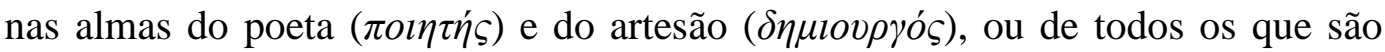

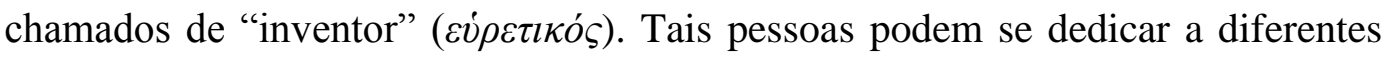
formas de poiesis: há os que se dedicam à organização da cidade e da família; há também os sábios que deixam as leis como suas obras, tal como o fez Sólon (209d-

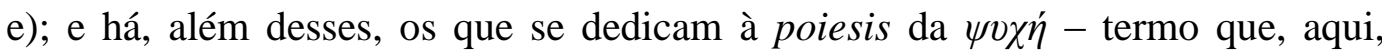
preferimos não traduzir, para que seja resguardada a possibilidade de ambos os significados, "alma" e "vida". A poiesis da $\psi v \chi \eta ́$ gera uma prole "muito maior do que a dos filhos" (209c). Os indivíduos que a praticam, depois de terem admirado e invejado Homero e Hesíodo, deixam de si uma herança imortal, "sendo eles

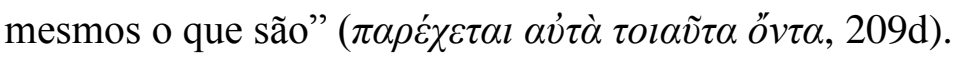

Ter sobre a própria vida a ingerência que um artesão tem sobre a sua obra parece ser um tema da Carta VII. Apenas que, conforme veremos com a análise do texto, para Platão essa possibilidade de autopoiesis não era um dado, mas uma conquista. Assim como apenas alguns homens se tornam poetas, também apenas alguns - os filósofos - arrebatam a possibilidade de tornar a própria trajetória vital uma criação autônoma. Veremos isso em detalhes na próxima seção.

\subsection{Platão e Dionísio II: o exemplo e o contraexemplo na Carta VII}

Conforme já dito, a leitura que propomos da Carta VII se compromete com a seguinte ideia: há um filósofo que investiga as próprias ações passadas, expõe as suas motivações e as exibe como o resultado de deliberações filosóficas. Há um sentido em que se pode dizer que o autor simplesmente informa sobre si próprio; mas há também um outro, em que ele perscruta a si mesmo, pondera sobre quem ele é e como chegou a se tornar a pessoa que se tornou. Tal exercício só é possível pela confluência de alguns fatores:

1. há pressuposta e já elaborada uma determinada noção do que seja o indivíduo humano; 
2. há a possibilidade de um afastamento suficiente em relação a si, como objeto a ser investigado, conhecido e narrado;

3. há também a possibilidade de uma investigação causal daquilo que narra - ou seja, da própria vida;

4. o autor se põe como fonte e origem das próprias ações.

Há aí uma sutil confluência entre o indivíduo que gesta a si mesmo, naquilo que estamos chamando de autopoiesis, e o indivíduo que narra a si mesmo. Se, respeitando as metáforas do Banquete e de Leis expostas há pouco, o filósofo é como o dramaturgo da própria vida, ele não o é apenas na medida em que compõe uma narrativa de que é o personagem principal, mas na medida em que forjou os acontecimentos ali narrados como o drama que constitui a própria vida.

Da maneira como Platão narra os acontecimentos na Carta VII, vê-se claramente que essa posse sobre si mesmo não é um dado, mas algo que se conquista - é o resultado de uma vida filosófica. Se nos apoiarmos nas considerações e discernimentos de Snell, Schmitz e Dodds sobre a formação do indivíduo, tal como relatados no capítulo anterior, talvez seja possível explicitar ainda este aspecto interpretativo: o indivíduo que não faz uma opção filosófica de vida - ou seja, que não examina a si mesmo, que não conhece a si mesmo, e que portanto segue movido por um desejo de glória vã, pela inveja dos sábios e virtuosos, pelas paixões da própria alma - segue, como os personagens homéricos, sendo um escravo das circunstâncias internas e externas. Segue submetido pelas condições em derredor, pelas manias divinas, pelas pulsões internas, por tudo aquilo que sobre ele se abate. No texto da carta, o próprio Platão e Dionísio II são descritos como sendo antípodas quanto a esses modos de vida, e extremos opostos quanto à possibilidade de autopoiesis. Também Díon é um exemplo ali posto e analisado, e sua virtude é louvada quando contrastada com a do tirano, embora também críticas sejam feitas quanto a algumas de suas ações e ao seu discernimento, em especial em relação aos acontecimentos que redundaram em seu homicídio - e é então que uma importante ponderação é feita a respeito da $\tau \dot{\chi} \chi \eta$, ou da fortuna que sobre ele se abateu. 


\subsubsection{O texto da carta}

Platão abre a carta explicando que assentirá em colaborar com a empreitada política de Hiparino II caso ele partilhe das ideias e concepções políticas que são as suas próprias, e que eram também as do falecido Díon. Ele então diz fazer questão de explicar como foi que tais ideias foram concebidas, e a partir de quais

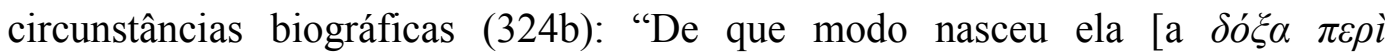
$\pi o \lambda \imath \tau \varepsilon i \alpha \varsigma]$ ? Não será indigno ouvi-la, sendo jovem ou não; vou tentar, do princípio, explicá-la a vós.” Ainda jovem, e antes de se dedicar à filosofia, as circunstâncias o levaram a tomar parte da Tirania dos Trinta - alguns familiares e conhecidos integravam o governo revolucionário e o convidaram a também participar. Os tiranos logo se mostraram maus governantes e, o que é pior, condenaram à morte seu amigo Sócrates. "Considerando então todas essas coisas e ainda outras tais não pequenas, desgostei-me e afastei-me dos males de então." (325a). Pelos tempos seguintes, "observando os homens que faziam política", e "quanto mais examinava as leis e os costumes", "tanto mais me parecia difícil ser correto o dedicar-me à política” (325c).

Tal relato inicial, que redunda na opção por um absenteísmo político ao menos temporário, já estabelece um forte contraste com a própria biografia de Dionísio II: ao contrário do que aconteceu com seu pai, ele não conquistou para si o posto de governo, mas foi parar ali pelo resultado de acontecimentos exteriores e inteiramente fora do seu controle. Plutarco narra que, nos 90 primeiros dias de governo, tudo o que o jovem tirano fez foi festejar, a ponto de estar constantemente ébrio e incapaz de discutir questões de Estado (Vidas, Capítulo VII, seção 4). Platão não faz menção explícita a isso, mas narra seu desgosto ao chegar à corte siracusana e lá ver apenas banquetes e festas e vida dissoluta, que impossibilitam as pessoas de se tornarem sábias (326c).

Quando o filósofo enfim se decidiu por dedicar-se à política, foi a partir de concepções filosóficas cuidadosamente gestadas (326b, com grifo nosso):

Fui obrigado a dizer, louvando verdadeiramente a filosofia, que a ela cabe discernir o politicamente justo em tudo dos indivíduos, e que a espécie dos homens não 
renunciará aos males antes que a espécie dos que filosofam correta e verdadeiramente chegue ao poder político, ou a espécie dos que têm soberania nas cidades, por alguma graça divina, filosofe realmente. Foi tendo isso em mente que cheguei à Itália e à Sicília, pela primeira vez.

Já aí também se anuncia um tema que perpassará o tema da carta: se o "por

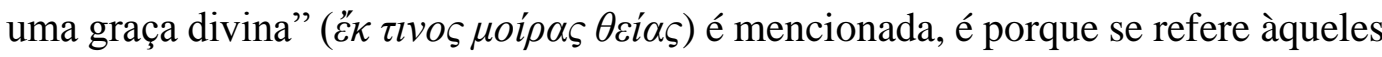
que, não tendo nenhum controle sobre si, precisam que a boa ventura lhes aconteça desde fora.

Não é em absoluto que o sábio tenha total ingerência sobre os acontecimentos externos: também eles são frequentemente lançados em situações por força da $\tau \dot{\chi} \chi \eta$, e também as suas ações deliberadas podem ter consequências imprevistas. Logo em seguida Platão observa que, Dionísio I ainda vivo, foi parar

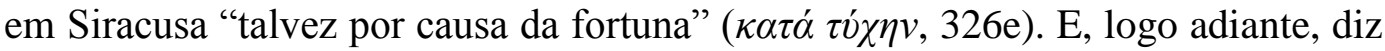
recear não ter se dado conta de que, ao fazer amizade com Díon nessa mesma estada, "arquitetava de algum modo, sem eu mesmo perceber, a dissolução futura da tirania" (327a). O sábio certamente não é clarividente e nem tampouco onipotente em relação ao mundo exterior e suas circunstâncias - tema que antecipa aquilo que dirá ao fim da carta, sobre o douto navegador que nem por isso tem controle sobre as tempestades.

Falecido o antigo governante, foi convidado a educar o jovem tirano, por Díon e pelo próprio Dionísio II. Novamente Platão vê nisso uma ocasião dada pelos deuses, que lhe cabia aceitar, em nome da coerência com os princípios filosóficos que discernira (327e): “(...) era preciso, se bem que mais longamente, perguntar: 'Que ocasiões melhores esperaremos, além das que agora se apresentaram, pela

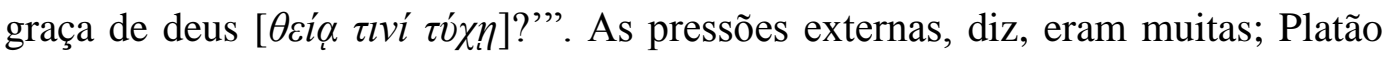
"tinha medo" (328b). Segue-se então o relato de uma longa hesitação, e um

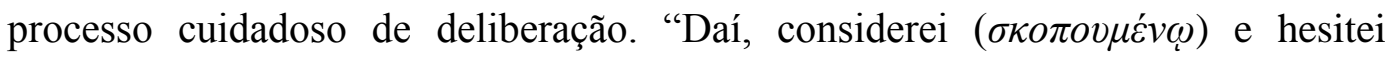
( $\delta \iota \sigma \tau \dot{\alpha} \zeta o v \tau \imath)$ sobre qual dos dois cursos seria preciso seguir: pôr-me a caminho e aceitar, ou fazer o quê?" O que o fez decidir, no fim das contas, foi convencer-se de que ali se apresentava uma "missão filosófica" a ser abraçada (328c): 
Contudo, a balança pendeu para o que havia a fazer. Pois, se algum dia alguém empreendesse levar a cabo o que foi pensado acerca das leis e do governo, agora mesmo havia que tentar. Visto que, mesmo tendo persuadido o bastante um apenas, eu seria capaz de executar tudo de bom. Com este estado de espírito e armado de ousadia, parti de casa, não como alguns imaginavam, mas envergonhando-me ao máximo de achar que era apenas capaz de um único discurso vazio, não empreendendo nenhuma ação (...)

Novamente tais descrições estabelecem um contraste imediato com as ações e ponderações de Dionísio II - que, ouvindo as opiniões e calúnias daqueles que o cercavam, acabou por impulsivamente voltar-se contra Díon, acusando-o de tentar usurpar o poder. Mandou-o então para o exílio (329b). O tirano prosseguiu em uma rotina de fingimento diante dos aliados de seu tutor, e diante do próprio Platão (329d). Era movido pela vaidade ("queria que eu o louvasse mais que a Díon e, para se distinguir, que eu o considerasse mais amigo do que a este", 330a) e não se interessava pelas lições de filosofia que lhe eram dadas (330a-b).

A narrativa da própria vida é então interrompida para que Platão dê conselhos aos destinatários da carta. O principal dentre eles é significativo, para os propósitos que estamos aqui perseguindo (331d-e): "primeiro, viver cada dia de modo a que fosse senhor de si mesmo, e a adquirir fiéis amigos e companheiros"

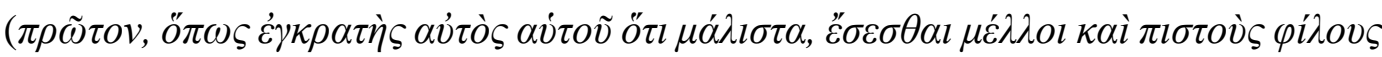
$\tau \varepsilon \kappa \alpha \grave{~} \dot{\tau} \alpha i \operatorname{\rho ov} \varsigma \kappa \tau \dot{\eta} \sigma \varepsilon \sigma \theta \alpha l)$. Apossar-se de si, escolher as companhias não por afetos aleatórios, mas por princípios filosóficos: tudo aquilo que, segundo o relato, o tirano não fez, embora os conselhos também lhe fossem dados (332d). Algumas páginas adiante, Platão cita a própria amizade com Díon como exemplo de uma relação que resulta não da "banal amizade" ( $\beta \alpha v \alpha v ́ \sigma o v ~ \varphi \imath \lambda o ́ \tau \eta \varsigma)$, mas pela "comunhão de

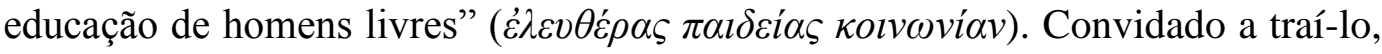
mediante a oferta de "bens e muitas honras", permaneceu fiel a ele (334b).

Ao fazer ponderações sobre os acontecimentos e a situação geral de Siracusa, Platão faz algumas considerações extremamente significativas, e que nos cabe analisar aqui. Tivesse ouvido os conselhos e guiamentos de Díon, Dionísio II teria transformado sua pátria em uma nação feliz e próspera (336a-b). Não foi o que aconteceu, e eis os reveladores termos em que as coisas são descritas (336b): 
ou alguma divindade ou algum espírito de vingança se


ilegalidade, impiedade e sobretudo com a ousadia da ignorância, nascendo todos os males que em tudo estão enraizados e germinam e ao fim produzem fruto amaríssimo. Essa mesma tudo reverteu e deitou a perder.

Em todo o texto da carta, é essa a única ocasião em que se diz que algo como uma divindade, ou um poder sobrenatural, agiu diretamente sobre a volição ou sobre o poder deliberativo de algum indivíduo. Sempre que as divindades são citadas, elas forjam as circunstâncias exteriores, abrem ou fecham as ocasiões para a ação humana. No trecho transcrito, a intervenção divina gera algo como uma ö $\tau \eta$, semelhante à que acometia os personagens homéricos - e aqui, muito significativamente, ela é associada à ignorância ( $\dot{\alpha} \mu \alpha \theta i \alpha)$, e dita a causa de "todos os males" ( $\pi \dot{\alpha} v \tau \alpha \kappa \alpha \kappa \alpha \grave{)}$.

O trecho se torna ainda mais significativo por duas razões. Em primeiro lugar, antecede uma reiteração do conselho de que os seus leitores vivam "de modo dórico", "segundo costumes ancestrais" (336c), "senhores de si" (336e), e também da advertência de que quem não o faz termina oprimido por "múltiplas sedições e contendas" (336d). As ideias, assim dispostas, parecem bastante relacionadas: os que não se assenhoram de si terminam possuídos por forças que os superam, e que podem ser descritas como uma espécie de possessão divina, tão pujantes se apresentam. Em segundo lugar: foi justamente essa possessão "por algum dáimon" que terminou por levar Dionísio II à ruína, com a deposição da sua tirania, conforme será exposto mais adiante. Submetido por forças e impulsos que não controla, o jovem governante não tem nenhuma ingerência sobre a própria vida, e nem mesmo sobre si próprio.

Quando retoma a narrativa autobiográfica, Platão dá notícia de que, passados alguns anos, chegaram-lhe notícias de que o tirano havia novamente se interessado pela filosofia e gostaria de tê-lo de volta para reiniciar o processo de educação (38e). Houve insistência de todas as partes: de Díon que, mesmo exilado, tinha esperanças de que o governante se regenerasse; de Arquídemos, discípulo de Arquitas; e do próprio Dionísio II, que chegou a enviar um trirreme a Atenas para 
buscá-lo. O que se segue é o longo relato da hesitação diante do convite (339b340a). Platão pondera que era preciso tentar ajudar Díon (339d); que de fato os jovens são impulsivos, e que Dionísio poderia ter amadurecido (339e); que seria prudente verificar pessoalmente as novas circunstâncias, para que não se fizesse responsável pelo malogro político de Siracusa (339e-340a). Diz, em 340a, que estava ainda apreensivo e acometido por maus presságios ( $\mu \alpha v \tau \varepsilon v ́ o \mu \alpha l)$, mas que partiu "protegido por esse raciocínio" ( $\lambda o \gamma l \sigma \mu o ́ \varsigma)$.

O filósofo então aplicou-lhe o "teste": expor ao postulante a discípulo todas as dificuldades envolvidas no aprendizado da filosofia, e ver como reage. Dionísio, naturalmente, não passou (341a-b). Platão prontamente desistiu dele, e logo compreendeu que as notícias de entusiasmo com a filosofia eram falsas. Não pôde, no entanto, voltar imediatamente para casa, porque foi mantido em uma espécie de cárcere domiciliar (347a).

Dentro do excurso filosófico, Platão ainda faz uma observação bastante significativa quanto ao ponto que estamos aqui perseguindo: ele de alguma maneira afirma que o contraste entre os que se apossam de si mesmos e os que são lançados a esmo pelas circunstâncias também é válido cognitivamente. Enquanto os homens não se voltam decididamente para o "quinto modo" cognitivo - ou seja, observar os entes em si mesmos -, e enquanto se prendem às palavras, discursos, imagens e conceitos puramente mentais, eles permanecem à mercê de condições aleatórias, das ideias e noções que por acaso se apresentaram a ele. É o ato de voltar-se para a realidade última que traz ao filósofo a autonomia intelectiva que lhe é própria. Diz ele (343c-d):

Nessas coisas não estamos acostumados a procurar o que é verdadeiro, por má educação; aceitamos a primeira dentre as imagens que foi apresentada. Não somos ridicularizados uns pelos outros, os que são interrogados pelos que interrogam, enquanto pudermos descartar e contestar os quatro modos.

E, mais adiante, outra formulação bastante reveladora: aqueles que confundem as formulações com o próprio saber, aqueles que tomam fórmulas prontas com a verdadeira filosofia, "então não deuses, mas mortais o fizeram perder o juízo" (344c-d). A passagem se apropria e modifica versos da Ilíada (Canto VII, 
v. 360 e Canto XII, v. 234), em que o aedo diz, em versos idênticos, que algum personagem perdeu a sanidade por ação das divindades: "não há dúvida de que os deuses te deram cabo da mente" (trad. de Frederico Lourenço). Eis onde, mais uma vez, a ignorância filosófica é comparada a uma possessão divina, ou à perda de controle sobre "sua parte mais nobre" ( $\kappa \alpha \lambda \lambda i \sigma \tau \eta)$.

Em 345d, Platão avalia retroativamente a decisão de ter aceitado a terceira viagem a Siracusa, e atribui a responsabilidade da má decisão a si próprio, por ter cedido às pressões externas: "Achei que não precisava estar mais irado com Dionísio do que comigo mesmo e aos que me forçaram a ir”. Delibera então quais razões teve para isso, e como deveria ter agido.

Já se encaminhando para o fim da carta, ele passa ainda a algumas avaliações de todos os acontecimentos - por que se deram, e como as coisas terminaram de maneira tão lamentável, com a deposição do tirano e o assassinato de Díon. Conta que tentou ainda a reconciliação e o acerto entre Dionísio II e seu tio, mas que Díon resistiu. E atribui o fim trágico do tirania à $\alpha \mu \alpha \rho \tau i \alpha$ inconsequente do governante: "nenhum desses [fatos] jamais viesse a acontecer, se Dionísio entregasse os bens a Díon" (350d-e). E repreende também as ações e escolhas do próprio amigo morto, ao dizer que "um homem justo entre os injustos, moderado e consciente, jamais seria completamente iludido pela alma dos outros" (351d).

A análise detalhada da carta deixa portanto transparecer essa ideia: o sábio é dono de si, sabe em qual situação se encontra e sabe perscrutar as razões. A autopoiesis do narrador tem aí um sentido ambíguo: ele não é "autor da própria vida" apenas no sentido em que a narra - algo de que seria capaz também um indivíduo distante da filosofia; ele o é porque é o autor dos próprios fatos narrados, e está ciente da razões das suas decisões, das suas motivações, e de toda a sua trajetória existencial. Ele é o autor da própria vida tanto quanto, para adotar a metáfora por ele mesmo usada, um navegador é o autor da sua trajetória pelos mares. 


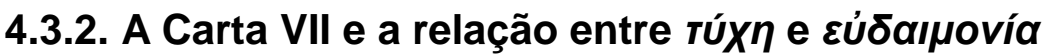

Um tema particularmente forte ao longo de todo o texto da carta é o da "fortuna" dos personagens envolvidos. Platão escrutina de maneira minuciosa não apenas o que lhes aconteceu, mas por que lhes aconteceu, e como tais "partes que lhe couberam" poderiam ter sido evitadas. Essa análise é aplicada ao próprio autor da carta, que reiteradamente afirma as próprias ponderações e decisões, boas ou más, como aitía dos episódios da própria vida. E a mesma análise é aplicada especialmente a Dionísio II e a Díon. Uma análise da maneira como tratou da questão na epístola pode nos ajudar imensamente a compreender de que maneira


sua vida, e a partir dos episódios observados na sua própria biografia.

Já vimos que o tirano de Siracusa é uma espécie de contraexemplo em relação à vida filosófica - descrito como vaidoso, indolente, influenciável, invejoso e dado a fingimentos, ele erra cegamente pela vida, títere de circunstâncias que não compreende e muito menos controla. O caso de Díon, no entanto, é bem mais sutil: sábio, virtuoso e vocacionado para a filosofia, o amigo de Platão nem por isso escapou de um fim terrível, assassinado por uma trama conspiratória covarde. O texto da carta alterna entre louvar a sua memória e observar que também ele se deixou arrastar por paixões irracionais que, embora fossem compreensíveis diante das situações, nem por isso eram próprias de um sábio. Trata-se, é preciso lembrar, de uma carta de aconselhamento, e o propósito ali parece ser o de dar reforçada ênfase à importância da prudência política nas decisões de Estado.

Eis os termos em que Platão descreve o fim de Díon (351c-d):

Ao agir como agiu, Díon, preferindo sofrer a injustiça a cometê-la, soube guardar-se de sofrê-la; contudo falhou, tendo chegado ao ponto iminente de superar os inimigos; por isso não é de admirar que tenha sido vencido. Pois, um homem justo entre os injustos, moderado e consciente, jamais seria completamente iludido pela alma dos outros. Mas talvez não fosse de admirar que sofresse o destino de um bom piloto, a cuja visão não escaparia de todo a aproximação de uma tempestade, mas a sua grandeza 
portentosa e imprevisível. E que, por não ter podido escapar, afundasse por força.

O texto ecoa de maneira bastante clara a passagem do Eutidemo citada anteriormente: o sábio como piloto de um navio, e as circunstâncias exteriores como as condições climáticas. Aqui, no entanto, Platão parece de alguma maneira mitigar

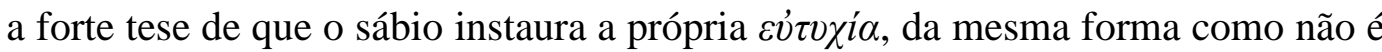
por acaso que um flautista bem executa uma melodia. Existe, sim, alguma $\beta i \alpha$ ou "força" a que nem o sábio, o "moderado e consciente" ( $\sigma \omega ́ \varphi \rho \omega v \tau \varepsilon \kappa \alpha i ̀ ~ c ̌ \mu \varphi \rho \omega v)$, pode resistir.

O final da carta lança luz sobre um trecho anterior, em que, no momento em que aconselha seus destinatários, Platão atribui à má ventura os malogros na formação de um bom governo em Siracusa. É quando diz (337d-e): "Mas uma sorte mais forte do que os homens ( $\tau \dot{\chi} \chi \eta \delta \varepsilon^{\prime} \tau \iota \varsigma \dot{\alpha} v \theta \rho \omega \dot{\pi} \pi \omega v \kappa \rho \varepsilon i \tau \tau \omega v$ ) dissipou o projeto. Tentai agora vós, com melhor sorte ( $\varepsilon v i v \chi \varepsilon ́ \sigma \tau \varepsilon \rho o v)$, realizar o mesmo com a boa

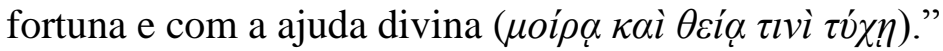

Estamos certamente mais próximos, portanto, das concepções sobre o assunto apresentadas na Apologia e no Fédon. Reforça-o ainda uma imagem usada em outro trecho da carta, que traz claros ecos do episódio da morte de Sócrates. Trata-se do passo 334d-e, em que Platão apresenta as seguintes ideias: ele exortou tanto Dionísio II quando Díon à vida filosófica. O primeiro não o ouviu, e hoje se encontra mal; o segundo o ouviu e, se o seu destino parece ruim aos que veem de fora, é porque não compreendem que a injustiça é um mal maior do que a própria morte. Diz o texto ${ }^{149}$ :

Dessas coisas eu tentei persuadir primeiro Díon, depois, Dionísio e, em terceiro lugar, vós agora. Aceitai-me, por Zeus, terceiro salvador, tendo considerado Dionísio e Díon, dos quais um, por não me aceitar, não vive agora nobremente ( $\zeta \tilde{\eta} \tau \grave{\alpha} v \tilde{v} v$ ov่ $\kappa \alpha \lambda \tilde{\omega} \varsigma)$, e o outro, por, ao aceitarme, morreu nobremente ( $\tau \dot{\varepsilon} \theta v \eta \kappa \varepsilon v \kappa \alpha \lambda \tilde{\omega} \varsigma)$. Pois qualquer sofrimento a que se submete aquele que busca o que há de

\footnotetext{
${ }^{149}$ Excepcionalmente, usamos aqui tradução nossa, já que a tradução de José Trindade Santos e Juvino Maia ignorou o claro contraste que há no original entre $\zeta \tilde{\eta} \tau \dot{\alpha}$ võv ov̉ $\kappa \alpha \lambda \tilde{\omega} \varsigma$, "não vive agora nobremente", e $\tau \dot{\varepsilon} \theta v \eta \kappa \varepsilon v \kappa \alpha \lambda \tilde{\omega}$, "morreu nobremente". O segundo advérbio foi omitido.
} 
melhor para si e para a pólis, ainda que se sofra até o fim, é correto e nobre (ỏ $\rho \theta \dot{o} v \kappa \alpha \grave{l} \kappa \alpha \lambda o ́ v)$.

O trecho então prossegue para afirmar que nenhum homem é imortal, e que a imortalidade corpórea não seria de todo um bem, e que os bens e males se dão apenas na alma, esteja ela unida ou separada de um corpo (334e). Não é a morte, portanto, o maior dos males. E a seguir (335a-b), Platão afirma ainda que é preciso

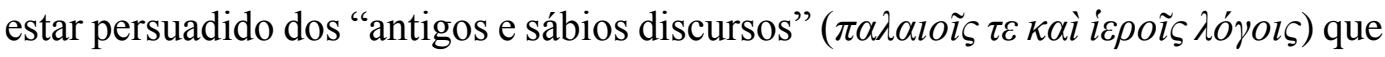
ensinam ser imortal a alma, e que, depois da morte do corpo, ela é submetida a julgamento e pode por isso sofrer maiores punições.

Destilados todos esses elementos, cremos ser possível ver aí uma "última palavra" de Platão a respeito da relação entre $\tau \dot{\chi} \chi \eta$ e $\varepsilon \dot{\delta} \delta \alpha u$ oví $\alpha$ - especialmente forte por ser uma avaliação de um caso concreto que considerava da maior importância, parte de alguns dos episódios centrais da sua própria biografia.

\subsection{3. "Esses não sabem nem de si mesmos"}

Se toda a Carta VII pode ser lida como um vasto exercício de exame da própria vida, um exercício do autoconhecimento que torna possível a poiesis de si, há nela um claro ensinamento que merece ser aqui destacado, para fins de ênfase. Platão deixa evidente que o problema maior dos homens não é propriamente a ignorância - as pessoas ignorantes podem obter uma vida ordenada e plena de

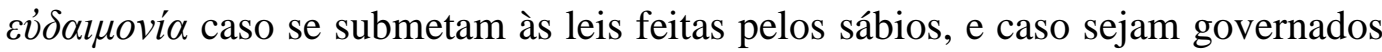
por reis filósofos $(335 \mathrm{c}-\mathrm{d})$. O que é descrito como realmente desastroso é a ignorância que não se reconhece como tal, e que portanto presume-se sabedoria. $\mathrm{O}$ mal é certamente potencializado caso seja essa a situação dos próprios governantes - e é precisamente essa a situação de Siracusa, por conta da ação de um tirano débil de autoconhecimento.

Se o preceito délfico não é em nenhum momento citado ipsis litteris, há uma alusão clara feita a ele, e em um momento crítico. Logo antes do excurso, Platão 
trata do tipo mais perigoso que pode haver em uma sociedade: os falsos filósofos. E se refere especialmente àqueles que escrevem e publicam obras sobre assuntos que não dominam, ou que põem em registro aquilo que não deve ser registrado. No contexto, ele está aludindo diretamente ao livro de Dionísio II, que não chegou a ler, mas de que teve notícia. O tirano "pretendia saber, e ter compreendido muito e até o máximo das lições que mal havia ouvido de outros" (341b). Põe-no então na mesma categoria de "alguns outros" pretensos filósofos que professam irresponsavelmente. E é então que diz uma frase decisiva: “esses não sabem nem


daquilo que considera o verdadeiro caráter do aprendizado da filosofia.

Essa alusão à sabedoria délfica, para se referir à mais graves das questões de que trata na carta, nos parece servir como síntese da leitura que propomos da carta: um exposição sobre a necessidade de conhecer a si mesmo, de examinar a própria vida, com todas as consequências que isso traz - políticas, éticas, espirituais. É nesse sentido que, como uma demonstração prática desse preceito, e como a análise da envergadura e da importância que ele tem, com todos os seus desdobramentos, a Carta VII pode ser lida como a culminação filosófica desse tema, tão caro à sua obra. 


\section{O "TESTE" FILOSÓFICO NOS DIÁLOGOS}

\subsection{A Carta VII e a questão do "anonimato" de Platão}

Os capítulos anteriores pretenderam defender algumas teses distintas: a de que a Carta VII, por ser um relato autobiográfico, dá testemunho de uma transformação na noção de individualidade humana; que toda ela, e não apenas o excurso, tem grande importância; que, nela, Platão faz um exercício de autoconhecimento e de exame da própria vida, de alguma maneira fazendo culminar em uma autobiografia filosófica preceitos fundamentais de seu pensamento.

A importância da Carta VII, no entanto, não se resume a essas razões. Conforme notaram vários comentadores, trata-se de uma ocasião privilegiada em que o filósofo não se vale de interlocutores outros para expor ideias e reflexões filosóficas ${ }^{150}$. O fato não é trivial, e incidiria sobre um debate de grande envergadura que se desenvolveu ao longo do séc. XX sobre a forma de interpretar os diálogos. Explique-se: é frequente entre estudiosos o hábito de atribuir a Platão as opiniões de quem quer que seja o "personagem de condução" dos diálogos Sócrates, na maior parte das obras, mas também o Estrangeiro de Eléia, o Ateniense, Timeu ou Parmênides. Tais personagens são tratados como porta-vozes transparentes do próprio autor, e é com base na destilação da fala desses personagens que se torna possível afirmar coisas como "Platão defendia a teoria das formas eternas", ou "Platão acreditava na metempsicose". Em favor desse hábito interpretativo, é preciso dizer que ele de fato é bastante antigo. No Vidas e doutrinas, Diógenes Laércio o apresenta como a interpretação correta e não problemática (III, 52, trad. Mário da Gama Kury):

Suas opiniões pessoais ele [Platão] apresenta por meio de quatro personagens: Sócrates, Timeu, o hóspede ateniense,

${ }^{150}$ É claro que o discurso na primeira pessoa do singular é comum a todo o epistolário. De todas as cartas, no entanto, a VII é aquela de mais clara e profunda dimensão filosófica, além de ser também a maior em quantidade de texto. É também aquela mais frequentemente considerada autêntica pelos estudiosos. 
o hóspede eleático. Os hóspedes estrangeiros não são, como alguns autores supõem, Platão e Parmênides, e sim personagens imaginárias sem nome, pois mesmo quando Sócrates e Timeu estão falando é sempre Platão que expõe a sua doutrina.

Depois disso, Diógenes Laércio se propõe a fazer uma longa exposição das ideias de Platão, em 67-109, e abre o trecho com as palavras (III, 67): “A doutrina de Platão é a seguinte." Segue-se então uma compilação sistematizada de vários temas, retirados dos diálogos, com especial ênfase na filosofia da natureza do Timeu, mas que também traz elementos da República, do Fedro, de Leis, dentre outros. E mesmo antes disso, o próprio Aristóteles, aluno direto de Platão, frequentemente expõe e discute como sendo do próprio Platão ideias e hipóteses levantadas por seus personagens nos diálogos ${ }^{151}$.

Seja como for, pelo menos desde o séc. XIX alguns intérpretes têm levantado questões pertinentes em relação a esse modo de interpretar os escritos de Platão. Schleiermacher ${ }^{152}$ apontou algumas delas na introdução que escreveu para a sua tradução dos diálogos, e acabou por inaugurar toda uma tradição de interpretação que revisitou a obra a partir de uma nova abordagem. Ele convidava a um retorno ao texto dos diálogos, um maior respeito à "intencionalidade" dos escritos, a uma maior atenção à relação entre forma e conteúdo ${ }^{153}$, ao reconhecimento do caráter artístico das obras ${ }^{154}$ - Platão deveria ser reconhecido não apenas como filósofo, mas também como o dramaturgo que dá vida a personagens e encena discussões filosóficas. Influenciados ou não por esse marco inicial, no séc. XX a questão ganhou corpo, e chegou mesmo a receber um nome, a partir de um artigo de L. Edelstein ${ }^{155}$ : o "anonimato de Platão". Não será necessário aqui expor todos os termos e argumentos em torno da questão, mas será interessante resumir a tendência dessa corrente de interpretação em uma declaração talvez

\footnotetext{
${ }^{151}$ As passagens são reunidas e discutidas criticamente em CHERNISS, H. Aristotle's criticism of Plato and the Academy. Baltimore: Johns Hopkins University Press, 1944.

${ }^{152}$ SCHLEIERMACHER, F. Introdução aos diálogos de Platão. Belo Horizonte: Ed. UFMG, 2008.

${ }^{153}$ Op. cit., p. 31.

${ }^{154}$ Op. cit., p. 30.

${ }^{155}$ EDELSTEIN, Ludwig. "Platonic anonimity”. American Journal of Philology 83, 1962, pp. 1-22.
} 
bastante extremada, mas que esclarece a posição. É de Leo Strauss, em um livro sobre a filosofia política de Platão, Aristóteles e Tucídides ${ }^{156}$ :

Em nenhum diálogo Platão diz coisa alguma. Portanto, por eles não podemos saber o que Platão pensava. Se alguém cita uma passagem dos diálogos com o intuito de provar que Platão de fato sustentou essa ou aquela concepção, age de maneira tão razoável como aquele que enunciasse que, de acordo com Shakespeare, a vida é um conto narrado por um idiota, cheia de som e fúria, e que não significa nada.

Strauss afirma em seguida que os diálogos se prestam a registrar caminhos possíveis de pensamento e "opiniões salutares", mas não doutrinas com que o próprio autor se comprometesse. Neles, Platão seria, portanto, uma espécie de experimentador de ideias, e não um doutrinador ${ }^{157}$.

Também essa corrente interpretativa pode alegar em seu favor a existência de um precedente na própria Antiguidade. São bastante conhecidas as tendências da fase cética da Academia, sob a liderança de Arcesilau (316-242 a.C.) e Carnéades (214-129 a.C.), que se recusavam a encontrar nos escritos do mestre algo como uma dogmata a ser simplesmente aceita por seus discípulos. Também Proclo ${ }^{158}$, em seus comentários, faz notar como todo o contexto dramático, as características dos personagens, o estilo literário e as molduras narrativas qualificam e modificam as ideias apresentadas. Harold Tarrant ${ }^{159}$ escreveu um artigo em que tenta provar que há uma antiga tradição de leitura dos diálogos que os toma como uma exemplificação a respeito de como investigar questões, obras preocupadas a ensinar o leitor a pensar e a empreender sua própria busca pela verdade.

\footnotetext{
${ }^{156}$ STRAUSS, Leo. The city and the man. Chicago: Chicago University Press, 1964. p. 50.

${ }^{157}$ Posição semelhante é também defendida em WINGARTNER, R. H. The unity of the platonic dialogue. Indianapolis: Bobbs-Merrill, 1973, pp. 1-7. Afirma que Platão não endossa a fala de nenhum de seus personagens, nem mesmo de Sócrates ou do Ateniense.

158 V. PROCLUS. Proclus' commentary on Plato's Parmenides, trad. G. Morrow e J. Dillon. Princeton: Princeton University Press, 1987. pp. 20-46.

${ }^{159}$ TARRANT, H. "Where Plato speaks: reflections on na ancient debate.", in Who speaks for Plato (org. Gerald Press). Oxford: Rowman \& Littlefield, 2000. Todo o volume se dedica à questão do "anonimato platônico".
} 
A todas essas considerações se acrescentam outras. Por exemplo: se Sócrates é um porta-voz transparente de Platão, o que fazer com o fato de que esse mesmo personagem em certas ocasiões defende ideias manifestamente diferentes, mutuamente excludentes, e às vezes mesmo contrárias, nos vários diálogos? Seria o caso de simplesmente supor que Platão estava mudando de ideia em cada um deles, como que aprimorando sua doutrina, e que a cronologia dos diálogos nos daria sempre a "última palavra" sobre as ideias do filósofo? Ainda que seja o caso, o que é que nos autoriza, nos próprios diálogos, a fazer essa interpretação?

Diante de todas essas questões, um texto em que Platão fale diretamente sobre filosofia, na primeira pessoa e aparentemente se comprometendo com elas, ganha evidentemente uma importância especial. Alguns quiseram tomá-la como uma espécie de "gabarito" para várias das investigações empreendidas no resto da obra platônica ${ }^{160}$. Outros, mais modestamente, a tomaram como uma referência que talvez lançasse luz sobre pontos controversos do resto da obra platônica ${ }^{161}$.

Uma coisa, no entanto, todas essas tentativas têm em comum: elas tentam esclarecer pontos a respeito do conteúdo das ideias apresentadas nos diálogos: ou seja comparar doutrinas e teses apresentadas na carta a doutrinas e teses expostas pelos personagens nas demais obras. Nunca jamais a usam para lançar luz sobre o contexto dramático das obras - e eis uma hipótese que, segundo nos parece, é no mínimo possível levantar.

\subsection{O contexto dramático dos diálogos como moduladores do conteúdo filosófico}

Dentro dessa tendência de ir além da mera extração da exposição dos "personagens de condução", e da direta atribuição dessas exposições ao próprio Platão, ganhou força, nos últimos 60 anos, uma corrente interpretativa que dá

\footnotetext{
${ }^{160}$ G. Pasquali, por exemplo, usa o excurso filosófico como parâmetro para interpretar as passagens obscuras e as aporias do diálogo Crátilo. V. PASQUALI, G. Le lettere di Platone. Florença: Felice Le Monnier, 1938. p. 67 ss.

${ }^{161}$ V. p. e. SAYRE, K. "Plato's dialogues in the light of the Seventh Letter", in Platonic

Writings/Platonic Readings (org. Charles Griswald Jr.). NY: Routledge, 1988.
} 
especial ênfase ao contexto dramático das discussões empreendidas nos diálogos. Costumam levantar questões como as que se seguem. Nas obras, é comum que os personagens que se encontram para conversar digam de onde estão vindo e, ao fim do diálogo, digam para onde estão indo (como, por exemplo, no início da República). Também são comuns alusões ao ambiente onde se encontram (Eutífron, Eutidemo, Fédon, entre outros), ou ao comportamento da natureza em torno (é o caso do Fedro, fora dos muros da cidade, num diálogo pontuado pelo movimento do sol). Em alguns casos, discutem em privado (Mênon); em outros, diante de um público (como no caso do Górgias) ou de um grupo de amigos que tentam impressionar (Banquete, Cármides). Uma pergunta perfeitamente pertinente é: por que esses elementos são mencionados? Será que eles não modificam de alguma maneira o próprio conteúdo da discussão?

Além disso, há a questão dos personagens. Os indivíduos que dialogam nas obras de Platão não são nunca jamais um "personagem abstrato A" e um "personagem abstrato B", mas pessoas identificáveis, com personalidades, disposições e tendências bem demarcadas - em alguns casos, figuras que já eram ilustres em Atenas, como Górgias, Protágoras, Mênon ou Alcibíades, mas, mais frequentemente, caracteres que se revelam no próprio diálogo, conforme se desenvolve a investigação. Em que medida o fato de a busca dialética se dar com esses indivíduos modula aquilo que está sendo dito? Será que uma mesma investigação, sobre o mesmo tema, não se daria de maneira inteiramente diferente, com outras ideias e argumentos, caso fosse empreendida diante de outro personagem?

E, por fim, claro, há a questão da própria forma dialógica. Se o propósito de Platão fosse simplesmente o de apresentar e propor doutrinas já prontas e definitivas, por que razão não teria ele escrito simplesmente tratados expositivos? Por que, em vez disso, dar-se ao trabalho da composição de todo esse cuidadoso elemento dramático? Tais questões são especialmente pertinentes no caso de algumas das obras, como por exemplo o Banquete, em que, antes do discurso de Sócrates (frequentemente lido como a exposição direta da posição de Platão sobre Eros), são registrados cinco outros discursos, de evidente alcance filosófico e riqueza literária. Se se tratasse de meras opiniões errôneas a serem superadas e descartadas, qual a razão de registrá-las? 
Essas e outras questões têm sido reiteradamente levantadas, acompanhadas de tentativas de respostas a elas, por toda uma corrente de intérpretes desde a década de 50. Costuma-se ver um marco importante dessa corrente em um artigo de Philip Merlan ${ }^{162}$, com importantes contribuições e desenvolvimentos mais recentes, como o livro The play of the platonic dialogues ${ }^{163}$, de Bernard Freydberg, e influências mesmo em certas correntes de interpretação "analítica” dos diálogos ${ }^{164}$.

De todas as propostas interpretativas e novas luzes lançadas sobre a leitura dos diálogos, uma em especial pode ser relacionada diretamente com o conteúdo da Carta VII. Trataremos do tema na próxima seção.

\subsection{As "passagens de retenção", segundo Thomas Szlezák}

Em duas obras separadas ${ }^{165}$, o intérprete alemão Thomas Szlezák expõe a seguinte hipótese interpretativa para a leitura de Platão: nos diálogos, existe sempre claramente discernível uma "figura de condução" do processo dialético, ou seja, alguém que o próprio texto põe na condição daquele que retém alguma espécie de saber e procura despertar, por um processo maiêutico, o conhecimento em seu interlocutor. Essa "figura de condução", claro, em geral seria o próprio Sócrates, mas pode variar de acordo com o diálogo específico. E segundo ele, no entanto, esse processo maiêutico seria sempre finamente adaptado de acordo com as disposições éticas ou cognitivas do interlocutor em questão. Além disso, mais do que simplesmente adaptar ideias e argumentos às circunstâncias (naquilo que chama de "recepção individual"), existem também ocasiões em que o diálogo é francamente interrompido porque Sócrates não vê em seu companheiro de investigação o nível moral ou intelectual necessário para lidar com certas ideias,

\footnotetext{
${ }^{162}$ MERLAN, P. "Form and content in Plato's philosophy", in Journal of the History of Ideias, 1947.

163 NY: Peter Lang, 1997.

${ }^{164}$ V., p.e., GILL, C. \& McCABE, M. (orgs.). Form and argument in late Plato. Oxford: Oxford University Press, 1996.

165 SZLEZÁK, T. Ler Platão. SP: Loyola, 2005 e SZLEZÁK, T. Platão e a escritura da filosofia. SP: Loyola, 2009.
} 
sob o risco de mal compreendê-las ou mesmo de profaná-las - é o que ele chama de "passagens de retenção".

Essa hipótese interpretativa lança algumas luzes interessantes sobre vários dos diálogos - muitos daqueles ditos "aporéticos" o seriam não por um esgotamento natural da investigação, e não necessariamente porque o autor da obra se encontrasse ele próprio em aporia, mas porque a figura de condução teria desistido de levar a questão adiante. O registro da discussão ficaria, portanto, como um exemplo pedagógico desse preceito: existem pré-requisitos no exercício da filosofia. As obras aporéticas certamente teriam a serventia propedêutica de desvelar questões e problemas onde antes só havia certezas e opiniões não examinadas, e portanto de conduzir o leitor no caminho do autoexame - mas, do ponto de vista conteudístico, não iriam muito além disso. Além disso, seria um reforço da ideia: Sócrates e demais figuras de condução estariam primeiramente mais interessados em examinar pessoas do que em examinar ideias.

Todas essas considerações têm relações muito estreitas com o texto da Carta VII. Nela, Platão diz explicitamente, e sem nenhum espaço para ambiguidade, que existem, sim, requisitos morais e cognitivos para que alguém se dedique à filosofia. Mais do que isso, ele expõe claramente quais são esses requisitos, e por que razões Dionísio II malogrou em suas tentativas de se tornar um filósofo. Mais do que isso, conforme veremos, ele expõe muito claramente a ideia de submeter o postulante a discípulo a um "teste filosófico" - uma revelação que, conforme veremos, pode ser de grande utilidade dentro dessa linha de interpretação.

Eis, segundo defendemos, uma "ocasião com várias tranças na testa” para usarmos um texto de Platão em primeira pessoa de modo a lançar luz interpretativa sobre os diálogos ${ }^{166}$.

\footnotetext{
${ }^{166}$ Uma advertência se faz aqui necessária. Thomas Szlezák é sabidamente um representante da "escola de Tübingen-Milão", que desenvolve pesquisas a respeito das ditas $\alpha$ $\gamma \rho \alpha \varphi \alpha \delta o ́ \gamma \mu \alpha \tau \alpha$, ou "doutrinas não escritas" de Platão. Embora, em seus livros, seus modos de interpretação dos diálogos se reportem a essa tese, não há nenhuma relação de necessidade entre elas. Ou seja: é possível interpretar certas aporias como "passagens de retenção" sem subscrever a ideia de um ensinamento esotérico legado por uma tradição indireta, e menos ainda a ideia de que tal ensinamento fosse o cerne, a medula ou o coroamento da filosofia de Platão. Tampouco existe um comprometimento entre a tendência de dar atenção ao caráter dramático da obra platônica e assentir com as teses da escola de Tübingen-Milão - boa parte aliás dessas duas tendências de interpretação são perfeitamente independentes entre si. Este aviso é necessário porque a presente pesquisa não se compromete com e não se posiciona em relação a essa questão, e aproveita os vislumbres
} 


\subsection{A Carta VII e as condições para o aprendizado da filosofia}

Conforme já dito, no texto da Carta VII Platão expõe de maneira clara e inequívoca, sem a intermediação de nenhum personagem, quais são algumas das condições indispensáveis para que o aprendizado filosófico se dê - e o faz especialmente ao longo dos conselhos e do excurso filosófico. Além disso, em separado, nos relatos sobre os acontecimentos de Siracusa, apresenta de maneira igualmente direta quais foram as razões que o impediram de ter êxito ao tentar instruir Dionísio II - seus problemáticos traços de caráter, sua configuração ética e cognitiva etc. Uma breve análise desses registros será útil aqui.

Sobre os critérios gerais adotados por Platão na seleção dos aptos, eis o que diz a carta. Ao tratar do "teste" que aplica aos que se candidatam a estudar filosofia, ele pode observar a reação e discernir (340c-d):

Aquele que ouviu, caso realmente seja filósofo, tendo familiaridade e sendo digno da tarefa ( $\dot{\varepsilon} \dot{\alpha} v \mu \grave{\varepsilon} v$ öv $v \omega \varsigma \hat{\eta}$

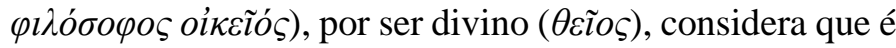

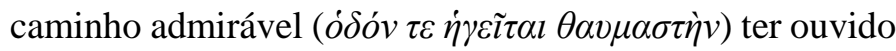

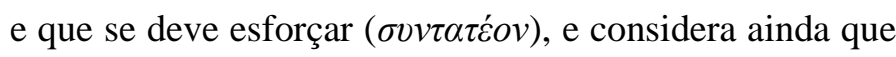
a quem faz assim não é possível viver de outro modo. Depois disso, tendo-o o seu guia iniciado nesse caminho, não desiste ( $\dot{\alpha} v i \eta \eta \sigma \imath v)$ antes de chegar a um fim em tudo, ou de ganhar força para por si próprio ser capaz de guiar, sem aquele que indica o caminho. É dessa maneira que vive esse homem, fazendo seja o que for. Mas tudo o que faz

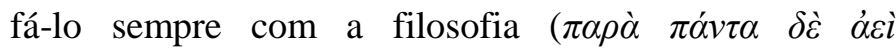


levando-o se for bom aluno, a ter boa memória, ser apto nos cálculos e sóbrio ( $v \dot{\varphi} \varphi o v \tau \alpha)$, em si mesmo. E qualquer modo de vida que seja contrário a esse ele acaba por odiar $(\mu l \sigma \tilde{\omega} v)$.

interpretativos exclusivamente na medida em que lançam luz sobre o texto de Platão e apenas a ele. A rigor, interessa-nos a ideia de que muitas investigações são abandonadas no momento em que a figura de condução desiste de seu interlocutor por enxergar nele disposições incontornavelmente incompatíveis com a busca filosófica. 
Há alguns pontos interessantes a serem extraídos aí. O primeiro, altamente significativo: Platão parece dizer que, mesmo antes do contato com a filosofia, mesmo antes da primeira lição, as pessoas já são naturalmente ou não filósofas. $\mathrm{Na}$ sequência do texto, comparará esses que "caso realmente sejam filósofas" com os que "não são realmente filósofos" (340d). Há portanto uma conaturalidade entre a filosofia e o indivíduo, e uma predisposição de alma que, pelo texto, não se esclarece ser ou não conquistável por algum tipo de prática, condicionamento, educação ou ascese. Além disso, ele "tem familiaridade" e "é digno da tarefa"

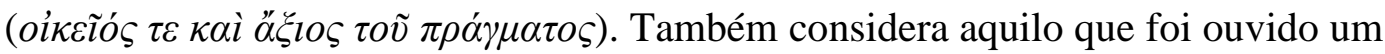


à famosa passagem de Teeteto $155 \mathrm{~d}$, em que Sócrates diz que o $\theta \alpha \tilde{v} \mu \alpha$ é estado de espírito típico dos filósofos. Em seguida, faz enfática referência à sua tenacidade na busca do saber, e sua disposição inabalável para a tarefa envolvida. Faz tudo "com a filosofia", e a toma como seu "alimento de cada dia". Platão passa então a descrever traços que são não requisitos, mas frutos do aprendizado filosófico: a boa memória, a aptidão para os cálculos, a sobriedade, e o repúdio ao "modo de vida contrário".

Mais adiante na carta (343e-344b), Platão volta ao tema da aptidão para a filosofia, e ainda acrescenta alguns pontos como condições para o aprendizado. Fala de uma aliança entre "a boa natureza do que conhece" e "a boa natureza do que é conhecido" ( $\varepsilon \tilde{v} \pi \varepsilon \varphi v \kappa o ́ \tau o \varsigma ~ \varepsilon \tilde{v} \pi \varepsilon \varphi v \kappa o ́ \tau \imath)$. Reafirma a necessidade de "natureza afim" ( $\sigma v \gamma \gamma \varepsilon v \eta \dot{ } \varsigma)$ e de "familiaridade com as coisas justas e de outras quantas coisas belas"

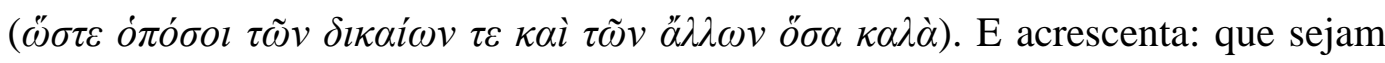
"dóceis em aprender e ao mesmo tempo de boa memória" ( $\varepsilon \dot{v} \mu \alpha \varepsilon \tilde{\varepsilon} \varsigma$ $\check{\alpha} \mu \alpha \kappa \alpha i$ $\mu v \eta ́ \mu o v \varepsilon \varsigma$; a mesma boa memória que, anteriormente, havia sido citada como fruto e não como condição). A seguir, faz uma observação bastante relevante: o filósofo por vocação procede por "refutações cordiais, perguntando sem inveja e usando

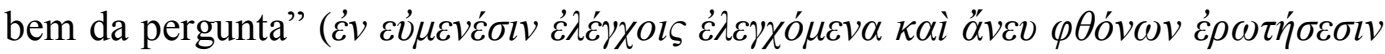

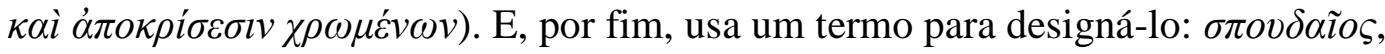
que poderia ser traduzido como "maduro" ou "sério".

Toda essa caracterização contrasta com a dos que "não são realmente filósofos" (340d-e). "Cobertos de opiniões, como os de corpos queimados ao sol", consideram o aprendizado filosófico "difícil e impossível para eles", e "não são 
capazes de levar a sério". Mais adiante, em 343e-334b, sobre estes diz palavras peremptórias:

Caso seja de má natureza ( $\kappa \alpha \kappa \tilde{\omega} \varsigma \delta \grave{\varepsilon}$ òv $\varphi v \tilde{\eta})$ para aprender e para os chamados bons costumes, por natureza, como é a condição da alma da maioria, tudo se corrompe, nem Linceu faria com que vissem. Numa palavra, quem não

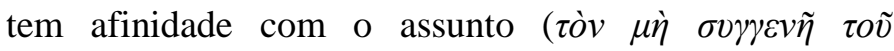
$\pi \rho \alpha ́ \gamma \mu \alpha \tau o \varsigma)$ não compreenderá nem pela facilidade nem pela memória, pois por princípio este não nasce por condições adversas. (...) indóceis em aprender e não de boa memória, nenhum desses jamais poderá aprender na medida do possível a verdade sobre a virtude e o vício; pois, ao mesmo tempo, é necessário aprender tanto o falso como o verdadeiro de tudo o que é, com todo esforço e muito tempo, como eu dizia no princípio.

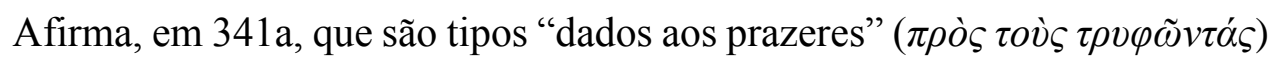

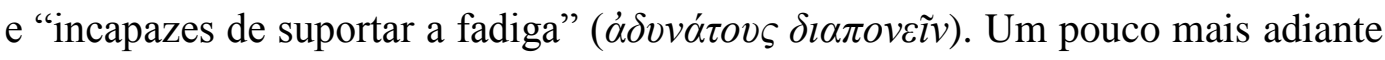
(344e), acrescenta ainda, sobre os que, ainda assim, publicam obras sobre filosofia ou professam sabê-la: "foi movido pela torpe soberba ( $\varphi \imath \lambda o \tau \imath \mu i \alpha)$, seja por tê-la tirado de si mesmo, seja como partícipe da educação, da qual não era digno, por desejar a glória advinda dessa participação".

Temos então um claro contraste: conaturalidade ("a boa natureza do que conhece" com "a boa natureza do que é conhecido": $\varepsilon \tilde{v} \pi \varepsilon \varphi v \kappa o ́ \tau o \varsigma ~ \varepsilon \tilde{v} \pi \varepsilon \varphi v \kappa o ́ \tau \iota$, 343e), disposição para o $\theta \alpha \tilde{v} \mu \alpha$, tenacidade, docilidade para aprender, boa memória, uso de refutações cordiais, bom uso e sem inveja das perguntas; por outro lado, abundância de opiniões, indolência, indocilidade, falta de memória, falta de afinidade com os assuntos, soberba e desejo de glória. Não é difícil vislumbrar, desde já, a caracterização de alguns dos personagens que de fato figuram nos diversos diálogos platônicos.

A todas essas considerações se soma ainda a caracterização de Dionísio II feita ao longo de toda a carta - caracterização que revela uma personalidade incompatível com o aprendizado da filosofia. O tirano é descrito como vaidoso e invejoso (330a: “queria que eu o louvasse mais do que a Díon e, para se distinguir, 
que eu o considerasse amigo mais do que a este"), indolente (330a: "hesitava em aprender e ouvir minhas lições sobre filosofia"), acometido de uma imprudência em que se mesclam a ignorância, a impiedade e a ilegalidade (336b: "algum espírito de vingança se abateu com ilegalidade, impiedade e sobretudo com a ousadia da ignorância"), dando nascimento a "todos os males" e a "fruto amaríssimo", soberbo e novamente vaidoso (338e-339a: "Quando (...) recusei o seu chamado (...), pareceu-me que Dionísio, por soberba, aspirava a que jamais alguns parecessem pensar que eu desdenhava de sua natureza e índole, e ao mesmo tempo que, conhecedor do seu modo de vida, o desprezasse).

Platão ainda acrescenta sobre ele um traço de extrema relevância: o de que o tirano tinha, de fato, aptidões intelectuais, mas era impedido por sua desqualificação moral. Em 338d, afirma: "ele não sendo de algum modo inepto

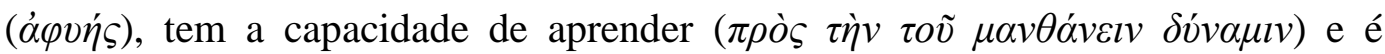
espantosamente cheio de soberba ( $\varphi \imath \lambda o ́ \tau \imath \mu o ́ \varsigma ~ \tau \varepsilon \theta \alpha v \mu \alpha \sigma \tau \tilde{\omega} \varsigma)$." O trecho deixa claro que a aptidão cognitiva de nada serve sem uma certa disposição ética.

\subsection{Platão revela a existência de um "teste" filosófico}

A Carta VII é também fonte para um elemento que não figura em nenhum dos diálogos, mas que talvez nele se faça presente de maneira sutil, conforme veremos. Trata-se de um dado fascinante, porque nos dá acesso a um procedimento pedagógico usado por Platão na condição de professor, com o intuito de selecionar os discípulos aptos, e especialmente pelo critério ético, ou pela disposição de alma. O filósofo revela dispor de um "teste" para averiguar a boa disposição dos postulantes a discípulos. Pela maneira como se refere a essa prova, parece se tratar de algo já bem desenvolvido e aplicado regularmente, com o curioso acréscimo de que é especialmente útil para ser aplicado a tiranos (o que evidentemente nos faz indagar quantos tiranos chegaram a solicitar as aulas de Platão). Eis a descrição do teste, nas palavras do próprio (340b-341a): 
Ora, há um meio de fazer experiências ( $\pi \varepsilon \imath \rho \alpha i)$ sobre isso, bem apropriado, mas que é realmente conveniente para tiranos, particularmente para aqueles cheios de falsas noções $(\pi \alpha \rho \alpha ́ \kappa o v \sigma \mu \alpha)$. (...) É preciso indicar a essa gente que todo o assunto exige trabalho, e que do trabalho vem a fadiga ( $\pi o ́ v o \varsigma)$. (...) Esta é a prova $(\pi \varepsilon \tilde{\imath} \rho \alpha)$ mais clara e mais segura, para os que são dados aos prazeres e incapazes de suportar a fadiga. Não há, pois, que lançar a culpa ao mestre, mas a si próprio, se não for capaz de praticar tudo o que for necessário à filosofia.

O "teste filosófico" parece dar bastante ênfase ao labor envolvido no aprendizado da filosofia, na medida em que envolvia uma exposição inicial e resumida de todo o caminho a ser percorrido, e ao modo de vida de que se faria acompanhar. Mas também é certo que não se resumia a isso: a descrição integral do teste também o reputa capaz de aferir a "docilidade" do postulante, sua "conaturalidade" com as coisas a serem conhecidas, sua propensão ao "divino", a facilidade com que se dá por satisfeito com os ensinamentos já apresentados. É, no fim e ao cabo, uma maneira de testar o caráter daquele que se propõe a aprender.

Dionísio II, como era de se esperar, malogra. Ele já "pretendia saber e ter compreendido muito e até o máximo das lições que mal havia ouvido de outros" (341b). Platão então desiste de todo de tê-lo como aluno, e só não voltou imediatamente a Atenas porque foi impedido. Essa categórica desistência talvez possa ser tomada como uma imagem de todas as ocasiões em que, nos diálogos, Sócrates ${ }^{167}$ abruptamente interrompe a discussão, alude a uma razão qualquer e abandona a investigação em estado de aporia.

${ }^{167}$ Essa abrupta interrupção não chega a acontecer com nenhuma das outras "figuras de condução" dos diálogos, e são típicas das obras ditas "aporéticas". 


\subsection{A ideia de um "teste" filosófico aplicado aos diálogos.}

Seria certamente descabido procurar nos diálogos platônicos a aplicação literal de um "teste" tal como descrito no passo 340b-341a da Carta VII. Os diálogos não comportam a presença de uma exposição sistemática, preliminar ou introdutória, de um currículo capaz de afugentar os interlocutores com más predisposições e de atrair os que tenham a índole correta ${ }^{168}$. E no entanto talvez seja possível algo desse mesmo espírito nas obras. Conforme veremos, há inúmeras ocasiões nos diálogos em que as figuras de condução advertem preliminarmente sobre as dificuldades envolvidas na investigação, e observam se os interlocutores estão dispostos a percorrê-las. Em outros casos, certas perguntas parecem servir como pedras-de-toque em relação às disposições do interlocutor, e as respostas dadas são altamente reveladoras quanto ao caráter dos personagens. Em ambos os casos, a indisposição ou a incompatibilidade ética do interlocutor são suficientes para que o diálogo seja interrompido. Relacionando essa ideia à dos capítulos anteriores desta pesquisa, os sutis testes feitos por Sócrates seriam uma maneira de pôr à prova até que ponto o interlocutor "conhece a si mesmo", até que ponto ele está pronto para reconhecer a vastidão da própria ignorância, ou a mostrar-se insatisfeito com lições e opiniões "que mal tinha ouvido", e pôr-se no árduo caminho do conhecimento.

A tese que aqui defendemos não é senão essa: há exposições apresentadas ou perguntas feitas nos diálogos que têm antes o propósito de testar o caráter e a

\footnotetext{
${ }^{168}$ Em outro sentido, parece haver alguma relação entre o que Platão descreve como tendo sido o teste, como exposição sistemática, aplicado a Dionísio II, e a descrição do currículo de formação dos "guardiães" no Livro VII da República. Sócrates ali não está "testando" Gláucon, já que o interlocutor não está se candidatando a submeter-se àquela educação. Mas também ali há a exposição de um longo currículo, que começa com a música, a poesia e a disciplina física (521d-522b), e passa às diversas matemáticas (522c-531c) como preparo introdutório para o estudo da filosofia (526b-c). Só ao fim seria o discípulo instruído nas formas, inclusive na Forma do Bem (532a-b). Seriam longos anos de aprendizado, que os vulgos certamente considerariam excessivos (527e). Sócrates adverte que Gláucon não será capaz de compreender todos os pontos do currículo, porque ainda não tem o devido preparo, mas que poderia compreender o caminho a ser percorrido (533a). Em 535c-536a, expõe as características daqueles que devem ser educados: os que mostrarem disposição para tal trabalho, os que tiverem características naturais condizentes, os que forem virtuosos e temperantes - os mesmos critérios aludidos na VII. Em 537c, diz por fim: "É a melhor prova para saber se uma natureza é dialética ou não, porque quem for capaz de ter uma visão de conjunto é dialético, e quem

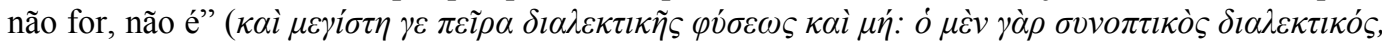
$\dot{o} \delta \dot{\varepsilon} \mu \grave{\eta}$ ov́.). Notem-se os elementos comuns: a ideia de um "teste", $\pi \varepsilon \tilde{\imath} \rho \alpha$, mediante a exposição de um árduo currículo, para discernir os vocacionados para a filosofia.
} 
disposição dos personagens. Alguns se saem bem, e a partir daí empreendem frutífera investigação. Outros claramente malogram - e, nesses casos, ou bem a figura de condução ou bem o próprio interlocutor interrompem a conversa e a encerra em estado de aporia. Nem todo impasse investigativo se deve ao esgotamento do assunto, mas muitas vezes à incompatibilidade - ética, no mais das vezes - constatada naquele que se propõe a empreender a dialética. $\mathrm{O}$ exame de alguns exemplos há de esclarecer o ponto.

$\mathrm{Na}$ impossibilidade de uma análise exaustiva dessas passagens em todos os diálogos, vamos proceder à análise de algumas delas, em casos que possam ser tomados como exemplares.

\subsection{Breves exemplos: o Laques e o Eutífron}

Antes de dois casos-modelo que serão expostos mais adiante, talvez seja útil mencionar alguns exemplos de diálogos em que os interlocutores mostram estar abaixo das condições mínimas para que uma investigação filosófica se dê. No Laques $^{169}$, Sócrates aparece para intervir em uma discussão que está prestes a ser decidida com uma simples votação (184d), e o filósofo os convence de que há uma investigação a ser empreendida. Nesse ponto, a conversa toma um caminho familiar: se pretendem educar os filhos na virtude, precisam antes saber o que seja a virtude (190b). O filósofo então propõe um longo percurso investigativo, composto de várias etapas, mas, segundo ele, necessário no contexto. Pondera (190c-e): conhecer a virtude é um trabalho árduo ( $\pi \lambda \varepsilon \dot{o} o v$ č $\rho \gamma o v)$; em primeiro lugar, seria preciso investigar uma instância ou ocorrência da virtude; começariam, assim, com a investigação da natureza da coragem; e então investigariam se a coragem pode ou não ser ensinada aos jovens; e, por fim, se a melhor maneira de ensiná-la é pelos estudos ou pelos exercícios. São portanto quatro etapas de investigação: o que é a coragem; se ela pode ser ensinada; se sim, qual a melhor maneira de ensiná-la; o que é, por fim, a virtude.

\footnotetext{
${ }^{169}$ A tradução citada é sempre de Carlos Alberto Nunes, exceto quando indicado em contrário.
} 
A discussão chega naturalmente a uma série de aporias logo na primeira dessas etapas. Quando Laques demonstra um certo desânimo diante da investigação, Sócrates sugere que se atenham com pertinácia ao tema (194a):

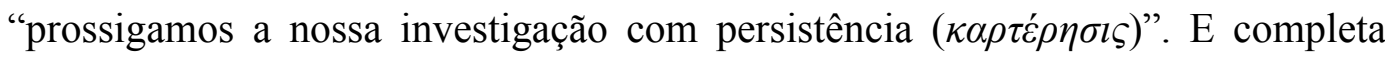
(194b): "Não é verdade, amigo, que o bom caçador deve acompanhar o rastro e nunca desistir?"

Em 199e, os interlocutores admitem por fim a aporia: nem mesmo a primeira etapa do caminho proposto foi vencida. Laques e Nícias iniciam então uma áspera discussão (199e-200c), em que se acusam de “desdém" e de "ignorância". Um culpa o outro pelo malogro da discussão. Sintomaticamente, eles desistem da investigação filosófica e propõem simplesmente entregar os jovens a Sócrates para que ele os eduque (199e-200c). Sócrates então diz que o estado de ignorância de todos ali, e dele próprio, é inaceitável (200e), e propõe que todos busquem se educar (201b). Lisímaco, aparentando impaciência, propõe que "por agora, encerremos ( $\delta l \alpha \lambda v ́ \sigma \omega \mu \varepsilon v)$ nossa conversação" (201c). Uma análise do quadro dramático como um todo revela que claramente não houve um esgotamento do assunto, mas sim um colapso no diálogo, indispostos que estavam os personagens para perseguir um assunto árduo até o fim.

No Eutífron ${ }^{170}$, Sócrates encontra o adivinho profissional que dá título ao diálogo no pórtico do arconte rei. O filósofo sofre as acusações que o condenarão à morte, e o religioso vai denunciar o próprio pai por homicídio. Perguntado se presume conhecer tão bem as coisas divinas e a própria piedade a ponto de saber de pronto o que agrada ou não aos deuses, Eutífron responde resolutamente que sim (4d-5a). Sócrates propõe então investigarem diretamente o que é "o piedoso" ( $\delta \sigma l o \varsigma)$, e segue-se uma minuciosa inquirição dialética sobre a sua natureza. Algum tempo depois, o adivinho já confessa sua exasperação com todo aquele exame, e reafirma sua convicção inicial $(14 a-b)$ :

Eutífron: Eu te disse há pouco, ó Sócrates, que seria $<$ trabalho $^{171}>$ por demais cansativo ( $\pi$ isiovos é $\rho \gamma o v$ ) aprenderes com minúcia tudo isso. O essencial é o

\footnotetext{
${ }^{170}$ A tradução citada é sempre a de Carlos Ablerto Nunes, exceto quando indicado em contrário.

${ }^{171}$ Carlos Alberto Nunes omitiu a tradução de é $\rho \gamma o v$.
} 
seguinte: quando alguém sabe o modo de dizer ou de fazer o que é agradável aos deuses, orando ou sacrificando, é o que se denomina piedade.

Sócrates então observa a falta de "disposição" ( $\pi \rho o ́ \theta v \mu o \varsigma, 14 \mathrm{c})$ do interlocutor. Já perto do fim do diálogo, diante dos impasses a que chegaram, o filósofo faz novo convite ao trabalho filosófico, e exorta a que seja tenaz (15c-d):

Devemos, portanto, examinar mais uma vez o que seja a piedade. De minha parte, enquanto não o souber, não desistirei de investigar. Não me desdenhes, mas concentra o espírito no máximo, para dizeres-me por fim a verdade.

E ouve por fim a recusa de Eutífron (15e): "Noutra ocasião, Sócrates; agora estou com pressa; já é tempo de ir-me embora". Aqui, não é a figura de condução que rejeita o interlocutor, mas o contrário. De toda forma, é igualmente clara a razão da aporia: sem o necessário pendor para a filosofia, e vislumbrando o trabalho árduo que se vislumbrava, o adivinho preferiu abandonar a investigação.

\subsection{Um caso paradigmático de malogro no teste: Mênon}

Talvez um dos casos mais emblemáticos para ilustrar a tese que estamos defendendo se encontre no diálogo Mênon $^{172}$. Em poucas outras ocasiões um interlocutor é tão claramente testado por Sócrates, e escancara as razões pelas quais malogra diante de perguntas e considerações que servem como um teste do seu caráter.

O diálogo, conforme se sabe, revolve em torno da noção de virtude, ou $\dot{\alpha} \rho \varepsilon \tau \dot{\eta}$. O personagem-título quer saber se ela pode ou não ser ensinada - uma questão de especial importância para um sofista profissional. Sócrates o convence de que, antes de chegarem a uma resposta a essa questão específica, precisarão

\footnotetext{
${ }^{172}$ Citaremos sempre a tradução de Maura Iglésias para esse diálogo.
} 
investigar o que seja a virtude (70b). Diante das falhas tentativas de Mênon, a questão será reapresentada reiteradamente, e cada resposta dada pode ser considerada mais reveladora a respeito do seu próprio caráter. Em $73 \mathrm{~d}-\mathrm{e}$, ele diz: “Que outra coisa se não ser capaz de comandar os homens?” Mais adiante, em 77b, dará nova resposta: “(...) parece que a virtude é, como diz o poeta, 'regozijar-se com as coisas belas e poder <alcançá-las>'. Também eu digo que a virtude é desejar as

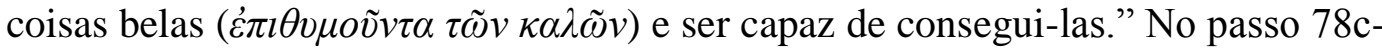
d, será mais uma vez convidado a esclarecer quais são as tais "coisas belas", e ele afirma: "Quero dizer também obter ouro e prata, e honras e postos de comando na cidade".

As três respostas são, como é evidente, altamente reveladoras. Deixam transparecer vários dos traços distintivos dos não vocacionados para a filosofia, segundo a Carta VII: soberba (338d), desejo de glória (344e), falta de conaturalidade com as coisas a serem aprendidas (344a).

Mais adiante, um outro traço: perguntado ainda mais uma vez sobre o que é a virtude (79e), Mênon desvia da questão e responde com uma objeção que o

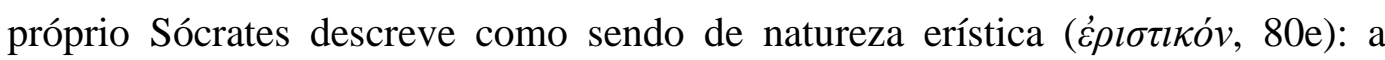
famosa aporia sobre a possibilidade do conhecimento. Não faz, portanto, o uso do "elencos cordial" aludido na carta, e parece incorrer no caso das "perguntas maliciosas" também ali aludidas (344b).

Resta ainda, claro, a questão da disposição para a fadiga filosófica. Ao longo do diálogo, Sócrates não só aponta a prioridade da questão “o que é”, como demonstra aos poucos todas as dificuldades nela envolvidas. Em 86c, uma nova apresentação da mesmíssima questão: “Queres então, já que estamos de acordo em que é preciso procurar aquilo que não se conhece, que tratemos conjuntamente de procurar o que é afinal a virtude?". A resposta é muito significativa (86c-d):

Mênon: Perfeitamente. Entretanto, Sócrates, eu, de minha parte, teria o máximo prazer em examinar e ouvir sobre aquilo que primeiro perguntei: se é como coisa que se ensina que é preciso tratá-la, ou como <coisa que advém> por natureza, ou como <coisa que advém> de que maneira afinal, quando advém aos homens, a virtude. 
Mênon portanto parece ter pressa, e quer da inquirição apenas uma resposta pronta para aquilo que lhe interessou de início. Não está disposto a desempenhar o penoso trabalho da filosofia (o que, na carta, constitui o requisito mais enfatizado como necessário para distinguir a vocação filosófica: 340b-341a). Veremos, mais adiante, o quão significativa será essa inflexão para o desfecho do diálogo. A resposta de Sócrates a esse respeito é igualmente reveladora (86d-e):

Sócrates: Ora, Mênon, se eu comandasse não somente a mim mas também a ti, não examinaríamos antecipadamente se a virtude é coisa que se ensina ou que não se ensina, antes de primeiro ter procurado o que ela é, em si mesma. Mas, já que tu não tratas de comandar-te a ti

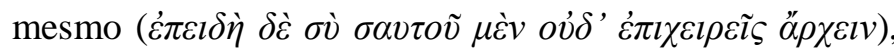
para que sejas livre (...), ceder-te-ei - pois que se pode fazer? Parece então que é preciso examinar que tipo de coisa é aquilo que não sabemos ainda o que é.

O lamento de Sócrates pela indisposição do seu interlocutor vem não apenas acompanhado do prenúncio do malogro da investigação, mas também de uma observação altamente significativa: o jovem Mênon é incapaz de "comandar a si mesmo".

Antes do desfecho, porém, há uma intrusão no curso do diálogo: Ânito surge à cena (89e) e interfere na conversa - mas logo será descartado, porque sua incompatibilidade com qualquer possibilidade de busca filosófica é flagrante e rapidamente constatada. Diante de uma tentativa de inquirição de Sócrates, que questionava uma proposta sua sobre quem fossem os malfeitores da Grécia, ele responde impacientemente (92d): “E por que não respondes tu mesmo?” Sem nenhuma disposição para os jogos da dialética, ele faz uma ameaça velada a Sócrates (94e: "eu te aconselharia (...) que tenhas cuidado") e se retira da discussão. O filósofo observará a seguir que Ânito está irritado ( $\chi \alpha \lambda \varepsilon \pi \alpha i v \varepsilon \imath v)$, e retoma a conversa com Mênon, que já se encaminha para o fim.

Antes de encerrar, Sócrates ainda faz uma observação carregada de implicações (96d): “Há o risco, Mênon, de que sejamos, eu e tu, homens medíocres 
(...). Assim sendo, mais do que tudo é preciso prestar atenção a nós mesmos

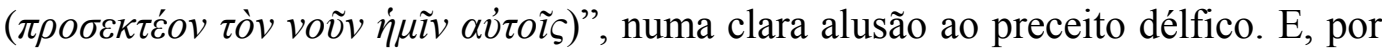
fim, anuncia ter desistido de empreender a busca filosófica com o jovem, e aponta a razão (100b):

(...) o que é certo sobre isso saberemos quando, antes de empreendermos saber de que maneira a virtude advém aos homens primeiro empreendermos pesquisar o que é afinal a virtude em si e por si mesma. Mas agora, é hora para mim de ir a outra parte (...)

O que é uma forma de dizer: a indolência diante daquilo que era necessário para a inquirição filosófica levou-os a um impasse insuperável. Sócrates deliberadamente interrompe a discussão, e parte.

\subsection{Um caso paradigmático de êxito no teste: Teeteto}

Se Mênon é um exemplo claro de interlocutor sem as qualificações necessárias para empreender uma investigação filosófica, o jovem matemático Teeteto é um exemplo igualmente claro da configuração contrária. Conforme é reiteradamente pontuado no diálogo, trata-se de um rapaz talentoso e vocacionado, dócil e curioso, e talvez por isso a discussão em torno do conhecimento seja tão longa e tão frutífera.

Também no Teeteto $^{173}$ é possível encontrar várias passagens em que Sócrates parece antes testar o interlocutor - e em cada uma dessas ocasiões o jovem se sai bem, e é enfaticamente elogiado pelo filósofo. Logo no início, em 144d, Sócrates elogia o seu caráter, ao saber que não é apegado ao dinheiro: "Pelo que

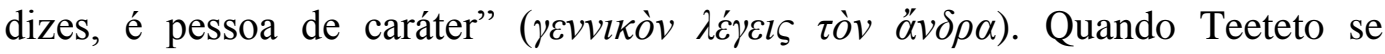
aproxima, o filósofo diz explicitamente que vai examiná-lo (145b): "Pois então, amigo Teeteto, chegou a hora de te mostrares e de eu te examinar" ( $\sigma o \grave{l} \mu \grave{\varepsilon} v$

\footnotetext{
${ }^{173}$ A tradução citada será sempre de Carlos Alberto Nunes, exceto quando indicado em contrário.
} 


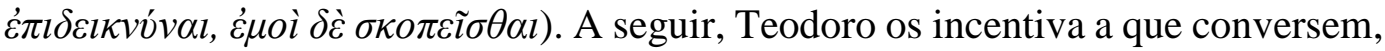
e Teeteto prontamente manifesta a sua boa disposição e seu intuito de ser corrigido ao longo da conversa (146c): “Terei de obedecer, Sócrates, uma vez que o ordenais. De qualquer forma, se eu cometer algum erro, vós ambos me corrigireis". Eis um claro exemplo da "docilidade para aprender" ( $\varepsilon \dot{v} \mu \alpha \dot{\theta} \theta \varepsilon \alpha)$ mencionada na VII, em 344a. Ele admite a própria ignorância logo no início da investigação (148b), e Sócrates faz então a primeira advertência sobre a dificuldade da tarefa a ser empreendido (148c): "Parece-te que descobrir o conhecimento, tal como o apresentei há pouco, seja tarefa secundária e não uma tarefa da mais alta responsabilidade?". Teeteto não apenas reconhece a dificuldade (148c, "Não, por Zeus; é dos mais difíceis”), como, diante da advertência de que deverá se esforçar, imediatamente se põe à disposição para o trabalho (148d): "Se é questão de disposição, Sócrates, manifestar-se-á. ${ }^{174,}$

Tudo isso acontece pouco antes da célebre passagem em que Sócrates se apresenta como o maiêutico - filho de parteira e parteiro ele próprio. Nesse discurso, ele afirma de saída (150b-c): "Porém a grande superioridade da minha arte consiste na faculdade de conhecer de pronto se o que a alma dos jovens está na iminência de conhecer é alguma quimera e falsidade ou fruto legítimo e verdadeiro.” Ou seja: alega ter o critério de discernimento entre os que estão prontos para a filosofia e os que não estão. E adverte enfaticamente sobre as muitas dores que estarão envolvidas no processo (151a): "Neste ponto, os que convivem comigo se parecem com as parturientes: sofrem dores lancinantes e andam dia e noite desorientados, num trabalho muito mais penoso do que o delas.” Dá as orientações necessárias para que o processo corra bem (151c): "quando eu te formular alguma questão, procura responder a ela do melhor modo possível”, e adverte para que o

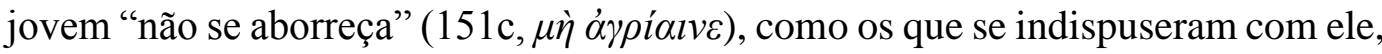
e mesmo como alguns que chegaram a agredi-lo fisicamente. Diante desse novo encorajamento, e de todas essas advertências, Teeteto reafirma o seu comprometimento com o processo (151d-e): "Realmente, Sócrates, exortando-me como o fazes, fora vergonhoso não esforçar-me ( $\pi \rho \circ \theta v \mu \varepsilon \dot{o} \circ \alpha \iota)$ para dizer com

174 Aqui nos afastamos da tradução de Carlos Alberto Nunes, que diz: "Quanto a esforçar-me, Sócrates, podes ficar tranquilo." O verbo no original é $\varphi \alpha v \varepsilon i \tau \tau \alpha l$, de $\varphi \alpha i v \omega$, que significa "brilhar" ou "manifestar". De toda forma, em qualquer caso está evidente a entusiasmada disposição de Teeteto para o trabalho intelectual. 
franqueza o que penso." E é prontamente elogiado pelo filósofo (151e): "Bela e corajosa resposta, menino. É assim que devemos externar o pensamento.”

Lidas dessa maneira, é possível sem maior esforço perceber nas primeiras páginas do Teeteto um teste feito por Sócrates ao seu interlocutor - um exame em que o personagem-título se sai muito bem. Autoconhecimento na assunção da própria ignorância, docilidade no pedido de ser corrigido (que será reafirmada em 161a), promessa de disposição para o árduo trabalho, mesmo diante da advertência de que as dores seriam maiores do que as do parto. Se juntarmos a isso o fato de que Teeteto é já um matemático, apto portanto para os cálculos e conatural às coisas a serem conhecidas, vemos aí cumpridos todos os requisitos expostos na Carta VII. Não à toa o diálogo logra chegar a tantos discernimentos.

Novos convites ao trabalho, com a advertência de que será um trabalho árduo, voltam a aparecer ao longo do diálogo. Em 155a, diz Sócrates: “Já que temos tempo de sobra, por que não recomeçarmos a nossa análise com toda a calma, sem nenhuma irritação, examinando-nos de verdade, para vermos o que, de fato, sejam essas visões que se formam dentro de nós?” Essa passagem logo é seguida pela muito famosa exposição que relaciona a vocação filosófica ao $\theta \alpha \tilde{v} \mu \alpha(155 \mathrm{~d})$ : "Estou vendo, amigo, que Teodoro não ajuizou erradamente a sua natureza, pois a admiração é a verdadeira característica do filósofo." O sentido da passagem é claro: Sócrates já testou Teeteto até enxergar nele uma verdadeira vocação filosófica. $\mathrm{O}$ jovem não será abandonado, e nem o aprendizado abruptamente interrompido.

Perto do fim do diálogo, Sócrates já não contém elogios ao rapaz (185e): "És lindo, Teeteto, não feio, como Teodoro disse há pouco; quem fala desse modo é belo e bom." Ambos reconhecem que, embora ainda não tenham chegado a conclusões terminantes, estão definitivamente melhores do que no início da conversa (187a-b). Em 195b-c, Sócrates mesmo admite o quão molestas e trabalhosas são as conversas que ele propõe, e Teeteto reage com desaprovação a esse juízo. Em 200d, o rapaz diz que a discussão só será interrompida se o próprio Sócrates estiver cansado.

Já estão próximos do passo 210, onde a discussão será encerrada certamente não por Sócrates ter discernido falta de vocação filosófica em Teeteto, mas, neste caso, pelo esgotamento de longas vias de investigação. Em 210b, eles 
avaliam positivamente o rastro de discernimento deixado no caminho, e em 210c o filósofo diz que o jovem matemático foi aperfeiçoado moralmente por todo esse processo dialético. Os dois se despedem, mas não sem que antes Sócrates prometa dar prosseguimento à educação do rapaz, retomando a investigação no dia seguinte (210d).

\subsection{Uma avaliação da ideia dos diálogos como "testes"}

Se uma preciosa ocasião em que Platão se expressa na primeira pessoa do singular pode ser usada como apoio para a leitura dos diálogos, parece razoável que a tomemos como parâmetro não apenas para a análise do conteúdo das doutrinas discutidas, mas também para o contexto dramático dos diálogos - que são, jamais esqueçamos, obras narrativas.

$\mathrm{Na}$ Carta VII, temos claramente exposta a ideia de que os que se apresentam para a tarefa filosófica devem ser testados. Ali também são explicitamente arrolados quais traços são indispensáveis para essa vocação, e quais são terminantemente incompatíveis com ela - uns e outros revelados diante dessa prova. E talvez possamos ler várias passagens dos diálogos platônicos, em especial dos ditos "aporéticos", menos como quem acompanha apenas uma busca filosófica e mais como quem testemunha testes de caráter - em que Platão talvez queira apresentar ao leitor a ideia de que, não observadas certas condições éticas, o ensino da filosofia é rigorosamente impossível. Na leitura dos diálogos, vemos que uns e outros feições morais compatíveis e incompatíveis com a filosofia - se fazem claramente presentes, e se manifestam conforme são "provocados" por Sócrates ou outras figuras de condução. Extrair portanto dos diálogos apenas o "conteúdo" das falas dos personagens sábios, e fazer delas a "doutrina” de Platão, é perder de vista que o filósofo tinha também outros objetivos em vista: ensinar, por exibição de exemplos claros, as condições para que o aprendizado filosófico aconteça.

É claro que nada disso pretende minimizar a importância dos discernimentos deixados como frutos das discussões, mesmo no caso dos diálogos ditos 
"aporéticos". Mas pretendemos aqui afirmar que eles também podem ser lidos como exemplos práticos daquilo que foi afirmado na Carta VII: os indolentes, os apegados às próprias opiniões, os soberbos, os imorais etc., não conseguem persistir no caminho da filosofia. 


\section{Considerações finais}

Se a presente pesquisa tinha um propósito, era o de propor uma interpretação da Carta VII que fizesse ressaltar a sua importância como obra filosófica, e não apenas como documento historiográfico. Conforme foi visto, o fato mesmo de ela ser um dos mais antigos relatos autobiográficos de que dispomos faz dela um testemunho especial sobre a gradual formação filosófica de uma nova maneira de compreender o que seja o indivíduo humano, e uma ocasião especial para estudarmos como Platão o compreendia. Uma autobiografia filosófica escrita pelo filósofo se relaciona intimamente com algumas das questões que lhe eram mais caras: a reflexão em torno do preceito délfico "conhece-te a ti mesmo", o imperativo da "vida examinada", o tema da boa vida a ser vivida.

Mais do que isso, é razoável que façamos bom uso da rara ocasião em que Platão escreveu sobre filosofia na primeira pessoa do singular, sem se valer das máscaras dos personagens de seus diálogos. Essa oportunidade de superar o problema do "anonimato" pode ser explorado em vários níveis diferentes, e a presente pesquisa pretende ter apresentado uma nova possibilidade de fazê-lo - a de usar a epístola como orientação interpretativa para o aspecto dramático dos diálogos.

Conforme dissemos na introdução desta pesquisa, talvez a Carta VII ainda não tenha encontrado o seu devido lugar na tradição de exegese da obra de Platão - em parte por conta da polêmica da autoria, em parte por um dimensionamento ainda débil da sua relevância filosófica. Esperamos ter contribuído, ainda que muito modestamente, para uma reavaliação dessas questões. 


\section{Referências bibliográficas}

\section{EDIÇÕES DA CARTA VII USADAS E CONSULTADAS}

PLATÃO. Carta VII. Tradução de José Trindade dos Santos e Juvino Maia Jr. RJ: Loyola/PUC-Rio, 2008.

. Diálogos: Vol. V. Fedro, Cartas, O primeiro Alcibíades. Tradução de Carlos Alberto Nunes. Belém: EDUFPA, 1975.

. Timaeus, Critias, Cleitophon, Menexenus, Epistles. Tradução de R. G.

Bury. Loeb Classical Library. Cambridge: Harvard University Press, 1929.

. The complete dialogues, including the letters. Tradução de L. A. Post.

Princeton: Princeton University Press, 1971.

. Lettres. Tradução de Luc Brisson. Paris: Flammarion, 2003.

Oeuvres completes. Tradução de Leon Robin. Bibliothèque de la Pléiade. Paris: Gallimard, 1950.

Le lettre di Planone. Tradução de G. Pasquali. Florença: Felice Le Monnier, 1938.

. Plato's Epistles. Tradução de G. R. Morrow. Indianápolis: BobbsMerrills, 1962.

\section{BIBLIOGRAFIA PRIMÁRIA}

ARISTÓTELES. The complete works of Aristotle. The revised Oxford Translation. Trad. Jonathan Barnes. Princeton: Princeton University Press, 1984. 
. Aristotle's Metaphysics. Trad. David Ross. Oxford: Claredon Press, 1981.

ARISTÓFANES. Lisístrata, As nuvens. SP: Abril Cultural, 1977.

CICERO. De finibus bonorum et malorum. Trad. H. Harris Rackham. Loeb Classical Library. Cambridge: Harvard University Press, 1929.

De officis. Loeb Classical Library. Trad. Walter Miller. Loeb Classical Library. Cambridge: Harvard University Press, 1929.

DIÓGENES LAÉRCIO. Vidas e doutrinas dos filósofos ilustres. Trad. Mário da Gama Kury. Brasília: UnB, 1987.

ÉSQUILO. Tragédias. Trad. Jaa Torrano. SP: Iluminuras, 2009.

EURÍPIDES. Medeia, As bacantes. Trad. Eudoro de Souza. SP: Abril Cultural, 1976.

HERÁCLITO. Fragmentos contextualizados. Trad. Alexandre Costa. SP:

Odysseus, 2012.

HERÓDOTO. História. Trad. Mário da Gama Kury. Brasília: EdUNB, 1985.

HESÍODO. Teogonia. Trad. Jaa Torrano. SP: Iluminuras, 2008.

Os trabalhos e os dias. SP: Trad. Mary de Camargo Neves Lafer.

Iluminuras, 2008.

HOMERO. Ilíada. Trad. Frederico Lourenço. Lisboa: Cotovia, 2008.

KIRK, RAVEN, SCHOFIELD. Os filósofos pré-socráticos. Trad. Carlos Alberto Louro Fonseca. Lisboa: Calouste Gulbenkian, 2008.

. Odisseia. Trad. Frederico Lourenço. Lisboa: Cotovia, 2008.

PLATÃO. Alcibiades. Cambridge: Cambridge University Press, 2001.

. Eutidemo. Trad. Maura Iglésias. RJ: Loyola/PUC-Rio, 2011.

. Fédon. Trad. Jorge Paleikat e João Cruz Costa. SP: Abril Cultural,

1972.

. Fedro. Trad. Carlos Alberto Nunes. Belém: EDUFPA, 2011.

. Mênon, Trad. Maura Iglésias. RJ: Loyola/PUC-Rio, 2001.

. Parmênides. Trad. Maura Iglésias. RJ: Loyola/PUC-Rio, 2003.

. República. Trad. Maria Helena da Rocha Pereira. Lisboa: Calouste

Gulbenkian, 1996. 
. Sofista. Trad. Jorge Paleikat e João Cruz Costa. SP: Abril Cultural, 1972.

. Teeteto. Trad. Adriana Manuela Nogueira. Lisboa: Calouste

Gulbenkian, 2010.

. Teeteto. Trad. Carlos Alberto Nunes. Belém: EDUFPA, 2001.

. Timeu. Trad. José Trindade dos Santos. Lisboa: Instituto Piaget, 2004.

PROCLUS. Proclus' commentary on Plato's Parmenides. Trad. G. Morrow e J.

Dillon. Princeton: Princeton University Press, 1987.

PLUTARCO. The parallel lives. Vol VI: Life of Dion. Trad. Bernadotte Perrin. Loeb

Classical Library. Cambridge: Harvard University Press, 1923.

SÓFOCLES. A trilogia tebana. Trad. Mário da Gama Kury. RJ; Zahar, 2001.

TUCÍDIDES. História da Guerra do Peloponeso. Trad. Mário da Gama Kury. Brasília: UnB, 1987.

XENOFONTE. Conversations of Socrates. Trad. Hugh Tredennick e Robin Waterfield. Londres: Penguin Books, 1990.

\section{BIBLIOGRAFIA SECUNDÁRIA}

ANNAS, J. "Self-knowledge and early Plato", in Platonic investigations. Studies in philosophy and the history of philosophy, Vol 13, ed. D. J. O'Meara. Washongton, 1985.

. The Morality of happines. Oxford: Oxford University Press, 1993.

BRANDÃO, Junito. Mitologia Grega. Petrópolis: Vozes, 1987.

BRANDWOOD, L. "Estilometria e Cronologia"in KRAUT, R. (org.). Platão. SP: Ideias \& Letras, 2013.

. "Plato's Seventh Letter", in Revue de l'Organisation internationale

pour l'Étude des Langues anciennes par Ordinateur. 1969, n. 4.

BREMMER, J. The Early Greek Concept of the Soul. Princeton: Princeton University Press, 1983.

BRISSON, Luc. Leituras de Platão. Porto Alegre: EDIPUCRS, 2003. 
. "Remarques Preliminaires", in: PLATON, Lettres, trad. Et presentation de Luc Brisson, Paris, Flammarion, 1997.

BURNYEAT, M. \& FREDE, M. The pseudo-platonic seventh letter (org. Dominic Scott). Oxford: Oxford University Press, 2015.

CAMPBELL, L. The sophists and the other companions of Socrates. Oxford: Oxford University Press, 1967.

CASKEY, E. G. “Again. Plato’s seventh Letter”, in Classical Philology 69, 1974.

CHERNISS, H. Aristotle's criticism of Plato and the Academy. Baltimore: Johns Hopkins University Press, 1944.

CORNFORD, F. F. Antes e depois de Sócrates. SP: Martins Fontes, 2005.

DEANE, P. "Stylometrics do not exclude the seventh Letter", in Mind 82, 1973.

DODDS, E. R. Os gregos e o irracional. SP: Escuta, 2002.

EDELSTEIN, L. Plato's Seventh Letter. Leiden: E. J. Brill, 1966. . "Platonic anonimity". American Journal of Philology 83, 1962.

FRANCO, I. O sopro do amor. RJ: Palimpsesto, 2006.

FREYDBERG, B. The play of the platonic dialogues NY: Peter Lang, 1997.

FRIEDLÄNDER, P. Plato - An introduction. Princeton: Princeton University Press, 1969.

GILL, C. \& McCABE, M. (orgs.). Form and argument in late Plato. Oxford: Oxford University Press, 1996.

GUTHRIE, A history of Greek philosophy: the later Plato and the academy, vol. 5. Cambridge: Cambridge University Press, 1978.

HADOT, Pierre. O que é filosofia antiga. SP: Loyola, 1999.

KRAUT, R. (org.) Platão. SP: Loyola, 2013.

LEVISON, M., MORTON, A. Q., A. D. WINSPEAR, A. D. The Seventh Letter of Plato. Mind. Mind, Vol. 77, No. 307. pp. 309-325, 1968.

LLOYD, G. E. R. "Plato and Archytas in the Seventh Letter", in Phronesis 35, 1990.

LONG, A. A. “Ancient Philosophy's Hardest Question: What to Make of Oneself?”, in Representations, No. 74. University of California Press, 2001. 
"Finding ondeself in Greek Philosophy", in Tijdschrift voor Filosofie.,

Nr. 2, Junho de 1992,

MARION, G. O oráculo de Delfos. SP: Odysseus, 2013.

MARROU, H-I. História da educação na Antiguidade. SP: Editora da Universidade de São Paulo, 1969.

MERLAN, P. "Form and content in Plato's philosophy", in Journal of the History of Ideias, 1947.

MEYERSON, I. “Les temps, la mémoire, l'histoire”, Jounal de Psychologie, 1956, p. 335 .

MISCH, G. History of autobiography in Antiquity, Vol. 1. London: Routledge, 2002.

MORROW, G. R. Plato’s Epistles. Indianápolis: Bobbs-Merrills, 1962.

NAGEL, T. The view from nowhere. Oxford: Oxford University Press, 1989.

NEHEMAS, A. The art of living: Socratic reflections from Plato do Foucault. Berkeley: University of California Press, 1999.

NIGHTINGALE, A. "Plato on aporia and self-knowledge", in Ancient Models of Mind. Studies in Human and Divine Rationality. (org. A. Nightingale \& D. Sedley). Cambridge: Cambridge University Press, 2010.

NUSSBAUM, M. A fragilidade da bondade. Fortuna e ética na tragédia e na filosofia grega. SP: Martins Fontes, 2009.

PARENTI, I. "La VII Epistola platônica et il suo excursus filosófico", in Atti dela Accademia Nazionale dei Lincei Classe di Scienze Morali, Storiche et Filologiche 198, 2001.

PARKE, H. \& WOEMELL, D. The Delphic Oracle, vol. 1. Basil: Blackwell, 1956. PASQUALI, G. Le lettre di Planone. Florence: Felice Le Monnier. 1938.

PEREIRA, M. H. da R. Estudos de história da cultura clássica, vol 1. Lisboa: Calouste Gulbenkian, 2006.

RABBOW, Paul. Paidagogia. Göttingen: Vandenhoeck, 1960.

REALE, G. "A grande importância da Carta VII para o pensamento de Platão", in Estudos Platônicos (org. Marcelo Perine). SP, Loyola: 2009. 
REEVE, C. D. D. Socrates in the Apology. Indianapolis: Hackett Publishing Company, 1989.

REIS, M. Experiência vital e filosofia platônica. Tese de Doutorado. PUC-Rio, 2004.

RITTER, C. Platon. Minuque: Beck, 1910.

SAYRE, K. "Plato's dialogues in the light of the Seventh Letter", in Platonic Writings/Platonic Readings (org. Charles Griswald Jr.). NY: Routledge, 1988.

SCHLEIERMACHER, F. Introdução aos diálogos de Platão. Belo Horizonte: Ed. UFMG, 2008.

SCHMITZ, H. System Der Philosophie. Vol 2: Der Leib. Bonn: Studienausgabe, 1982.

SCHULL, Pierre-Maxime. Essai sur la formation de la pensée grecque. Paris: Alcan, 1949.

SCHWALLER, I. Her-Bak: The Living Face of Ancient Egypt. London: Hodder and Staughton, 1954.

SHOREY, What Plato said. Chicago: Chicago University Press, 1934.

SNELL, B. A cultura grega e as origens do pensamento europeu. SP: Perspectiva, 2009.

STRAUSS, L. The city and the man. Chicago: Chicago University Press, 1964.

SZLEZÁK, T. Ler Platão. SP: Loyola, 2005. Platão e a escritura da filosofia. SP: Loyola, 2009.

TARRANT, H. "Middle platonismo and the Seventh Letter". In Phronesis 28, 1983, pp. 75-103.

. "Where Plato speaks: reflections on na ancient debate.", in Who speaks for Plato (org. Gerald Press). Oxford: Rowman \& Littlefield, 2000.

TAYLOR, A. E.. Plato: the man and his work. NY: Dover Publications, 2001. "The analysis of episteme in Plato's seventh Epistle", in Philosophical Studies, 1934.

VERNANT, J. P. Mito e pensamento entre os gregos. SP: EDUSP, 1973.

VLASTOS, G. Socratic Studies (org. M. Burnyeat). Cambridge: Cambridge University Press, 1994. 
WILAMOWITZ-MOELLENDORFF, U. von. Platon, vol. 2. Berlim, 1920.

WINGARTNER, R. H. The unity of the platonic dialogue. Indianapolis: BobbsMerrill, 1973.

WHITE, N. P. Plato on knowledge and reality. Cambridge: Hackett, 1976.

WOHL, V. "Plato avant la lettre, authenticity in Plato's epistles", in Ramus 27, 1998.

WOORDUFF. "Plato's earley theory of knowledge", in Essays on the Philosophy of Socrates (org. H. Benson). Oxford: Oxford University Press, 1992.

YOUNG, C. M., "Plato and Computer Dating", in SMITH, N. D. (org.), Plato: Critical Assessments volume 1: General Issues of Interpretation. Londres: Routledge, 1998. 